This document was too large to scan as a whole document, therefore it required breaking into smaller sections.

Document number: $S D-W 314-C D R-001$

Section $\angle$ of

Title: Conceptual Design Reporter for Tank Firm Restoration + Safe Operations Project W-3/4

Date: $5 / 03 / 96$ Revision: 0

Originator: S.R. BerGS

Co: WHC

Recipient:

Co:

References: EDT -614745 


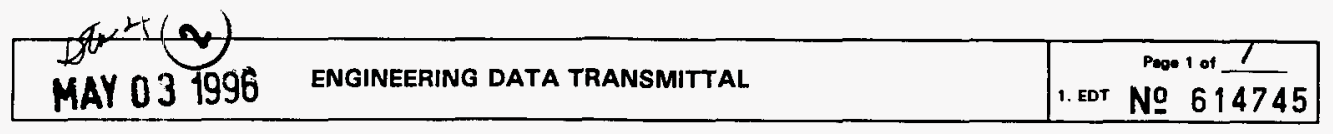

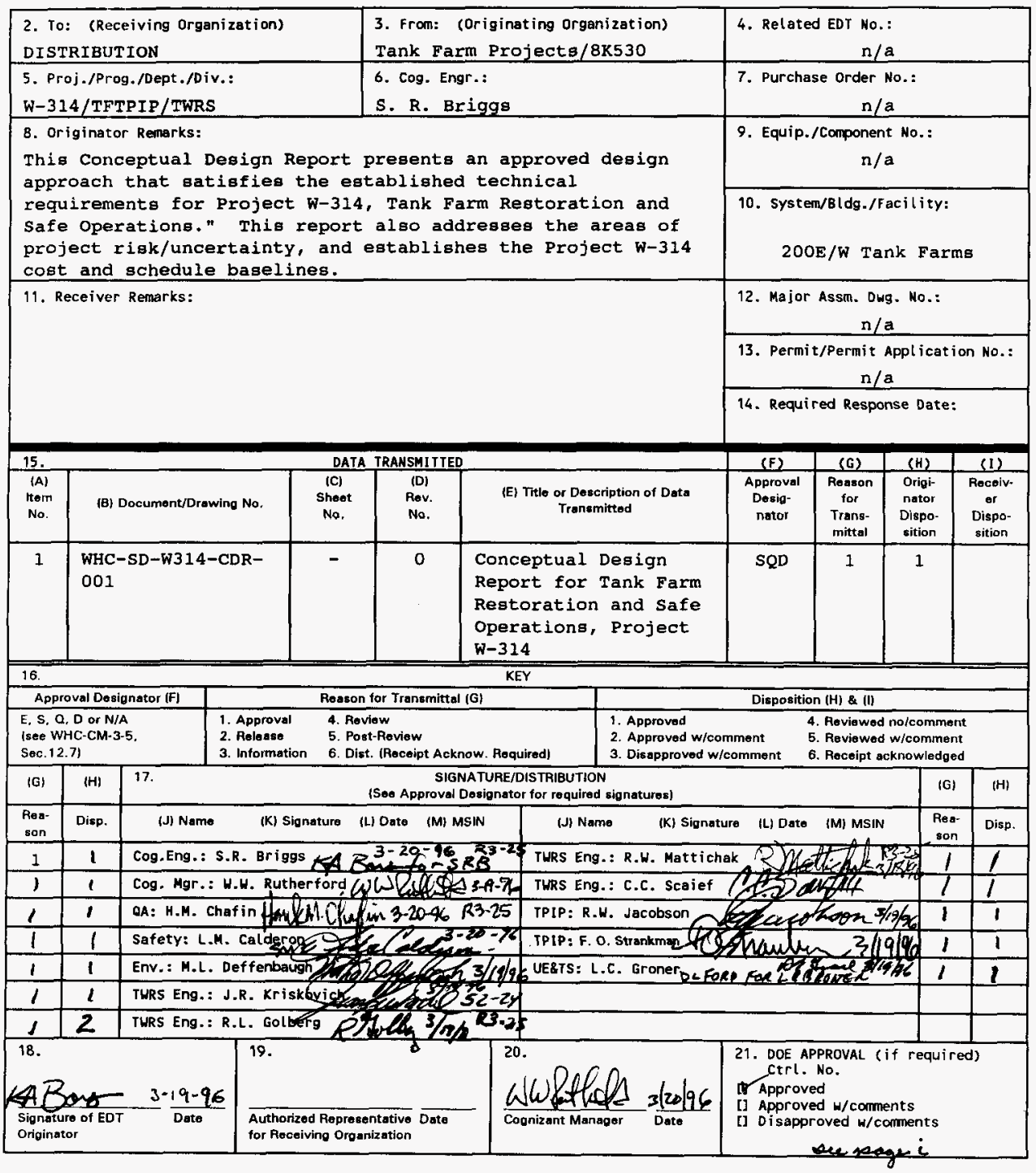

BD-7400-172-2 (04/94) GEF097 


\title{
Conceptual Design Report for Tank Farm Restoration and Safe Operations, Project W-314
}

\author{
S. R. Briggs \\ Westinghouge Hanford Company, Richland, WA 99352 \\ U.S. Department of EnergY Contract DE-ACO6-87RL10930

\begin{tabular}{|c|c|c|c|}
\hline & EDT 614745 & UC: $\quad 2030$ & \\
\hline rg Code: & $8 K 530$ & Charge Code: & $\mathrm{N} I$ \\
\hline Code & EW3130010 & Total Pages: & 345 \\
\hline
\end{tabular}

Key Words: Project W-314, Tank Farm Restoration and Safe Operations, Conceptual Design Report, Tank Farm Upgrades, Tank Waste Remediation Syotem, waste Transfer systems, Double-Shell Tanks, Single-Shell Tanks, Double Contained Receiver Tanks

Abstract: This Conceptual Design Report (CDR) presents the conceptuallevel design approach that satisfies the established technical requirements for Project $W-314$, "Tank Farm Restoration and Safe Operations." The CDR also addresses the initial cost and schedule baselines for performing the proposed Tank Farm infrastructure upgrades. The scope of this project includes capital improvements to Hanford's existing tank farm facilities (primarily focused on Double-shell Tank Farms) in the areas of instrumentation/control, tank ventilation, waste transfer, and electrical systems.

IRADEMARK DISCLAIMER. Reference herein to any specific comercial product, process, or service by trade name, tradenark, manufacturer, or otherwise, does not necessarily constitute or imply its endorsement, recommendation, or favoring by the United States Government or any agency thereof or its contractors or subcontractors.

Printed in the United States of America. To obtain copies of this document, contact: WhiC/BCS Document Control Services, P.D. Box 1970, Mailstop H6-08, Richland WA 99352, Phone (509) 372-2420; Fax (509) 376-4989.
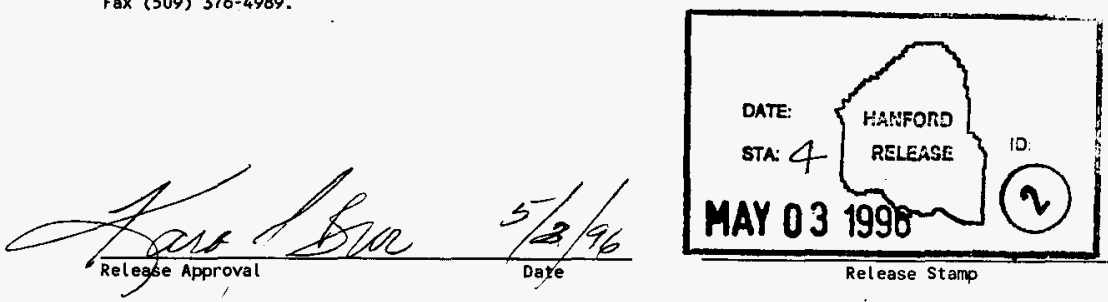

Approved for Public Release 
CONCEPTUAL DESIGN REPORT

\title{
TANK FARM RESTORATION AND SAFE OPERATIONS PROJECT W-314
}

\author{
Prepared for \\ Westinghouse Hanford Company
}

April 1996

Subcontract WHC-380393

Prepared by

ICF Kaiser Hanford Company

Richland, Washington

\section{W314CDR}




\title{
W314CDR
}

\section{CONCEPTUAL DESIGN REPORT}

\section{TANK FARM RESTORATION AND SAFE OPERATIONS}

PROJECT W-314

Prepared by

\author{
ICF Kaiser Hanford Company \\ Richland, Washington
}

for

Westinghouse Hanford Company

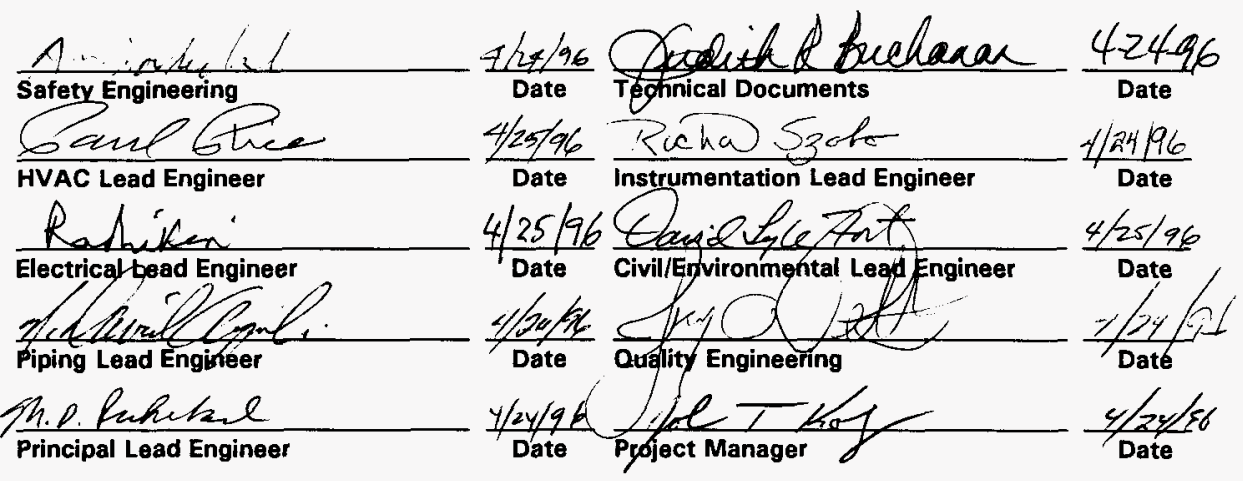

Westinghouse Hanford Company

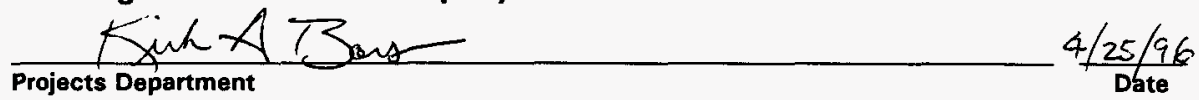

U.S. Department of Efhergy 
WHC-SD-W314-CDR-001, Rev. 0

This conceptual design report contains confidential commercial information that shall be used or duplicated only for official Government purposes, and this notice shall be affixed to any reproduction or abstract thereof. Disclosure of the confidential commercial information contained in this report outside the Government shall not be made without the advice of counsel. The restrictions contained in this notice do not apply to any data or information in this report which is not commercial information or to information generally available to the public on an unrestricted basis.

Reference: DOE Order 4700.1 


\section{TABLE OF CONTENTS}

I. INTRODUCTION $\ldots \ldots \ldots \ldots \ldots \ldots \ldots \ldots \ldots \ldots \ldots \ldots \ldots \ldots \ldots$

II. $\quad$ SUMMARY $\ldots \ldots \ldots \ldots \ldots \ldots \ldots \ldots \ldots \ldots \ldots \ldots \ldots \ldots \ldots \ldots$

III. JUSTIFICATION $\ldots \ldots \ldots \ldots \ldots \ldots \ldots \ldots \ldots \ldots \ldots \ldots \ldots \ldots \ldots$

IV. DESCRIPTION OF PROJECT SCOPE FOR AN TANK FARM $\ldots \ldots \ldots \ldots .5$

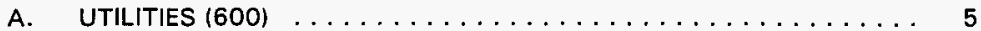

B. SPECIAL EQUIPMENT AND PROCESS SYSTEMS $(700) \ldots \ldots \ldots \ldots 7$

C. DEMOLITION (810) ....................... 19

V. DESCRIPTION OF PROJECT SCOPE FOR AP TANK FARM $\ldots \ldots \ldots \ldots 22$

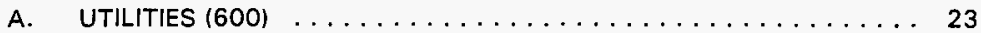

B. SPECIAL EQUIPMENT AND PROCESS SYSTEMS $(700) \ldots \ldots \ldots, 23$

C. DEMOLITION $(810) \ldots \ldots \ldots \ldots \ldots \ldots \ldots \ldots \ldots \ldots \ldots \ldots \ldots \ldots$

VI. DESCRIPTION OF PROJECT SCOPE FOR AW TANK FARM . . . . . . 29

A. UTILITIES (600) $\ldots \ldots \ldots \ldots \ldots \ldots \ldots \ldots \ldots \ldots \ldots \ldots \ldots \ldots$

B. SPECIAL EQUIPMENT AND PROCESS SYSTEMS (700) $\ldots \ldots \ldots 30$

C. DEMOLITION (810) .................... 34

VII. DESCRIPTION OF PROJECT SCOPE FOR AY TANK FARM $\ldots \ldots \ldots \ldots 36$

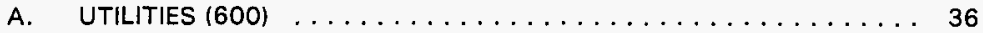

B. SPECIAL EQUIPMENT AND PROCESS SYSTEMS (700) . . . . 37

C. DEMOLITION (810) ..................... 41

VIII. DESCRIPTION OF PROJECT SCOPE FOR AZ TANK FARM $\ldots \ldots \ldots \ldots 44$

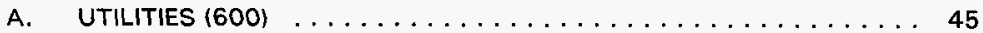

B. SPECIAL EQUIPMENT AND PROCESS SYSTEMS $(700) \ldots \ldots \ldots .45$

C. DEMOLITION (810) $\ldots \ldots \ldots \ldots \ldots \ldots \ldots \ldots \ldots \ldots, 49$

IX. DESCRIPTION OF PROJECT SCOPE FOR SY TANK FARM $\ldots \ldots \ldots \ldots \quad 52$

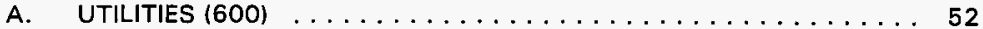

B. SPECIAL EQUIPMENT AND PROCESS SYSTEMS (700) $\ldots \ldots \ldots .53$

C. DEMOLITION (810) .................... 59

X. DESCRIPTION OF PROJECT SCOPE FOR THE SST FARMS $\ldots \ldots \ldots \ldots .62$

A. UTILITIES $(600) \ldots \ldots \ldots \ldots \ldots \ldots \ldots \ldots \ldots \ldots \ldots \ldots \ldots \ldots . \ldots \ldots 2$

XI. DESCRIPTION OF PROJECT SCOPE FOR 244-A DCRT $\ldots \ldots \ldots \ldots \ldots 63$

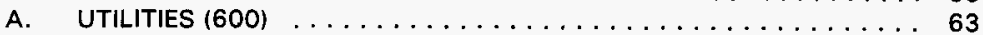

B. SPECIAL EQUIPMENT AND PROCESS SYSTEMS $(700) \ldots \ldots \ldots \ldots 64$

C. DEMOLITION (810) ........................ 67

XII. DESCRIPTION OF PROJECT SCOPE FOR 244-S DCRT $\ldots \ldots \ldots \ldots \ldots 70$ 


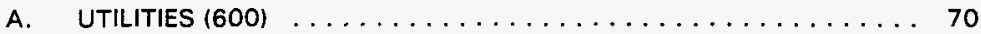

B. SPECIAL EQUIPMENT AND PROCESS SYSTEMS $(700) \ldots \ldots \ldots \ldots 71$

C. DEMOLITION $(810) \ldots \ldots \ldots \ldots \ldots \ldots \ldots \ldots$

XIII. DESCRIPTION OF PROJECT SCOPE FOR 200-EAST/200-WEST AREAS . . 75

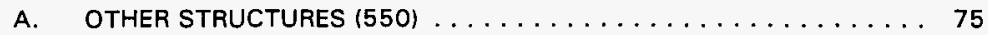

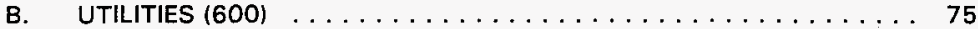

C. SPECIAL EQUIPMENT AND PROCESS SYSTEMS $(700) \ldots \ldots \ldots \ldots 75$

D. DEMOLITION $(810) \ldots \ldots \ldots \ldots \ldots \ldots \ldots \ldots \ldots \ldots \ldots$

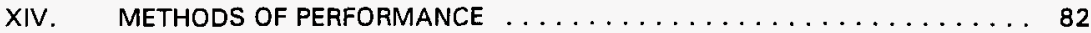

A. PROJECT MANAGEMENT (WBS 1.1 ) $\ldots \ldots \ldots \ldots \ldots \ldots \ldots \ldots$

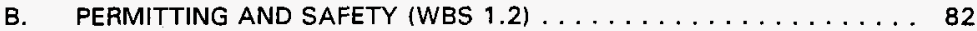

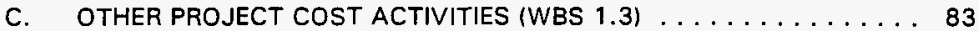

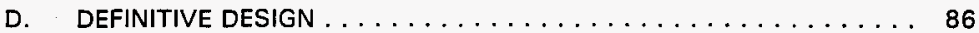

E. PROCUREMENT (WBS 1.5. A.3) $\ldots \ldots \ldots \ldots \ldots \ldots \ldots \ldots$

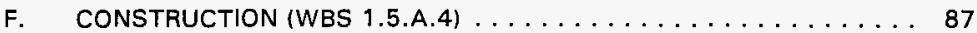

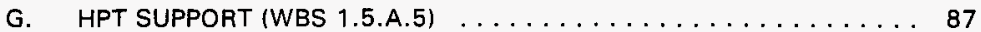

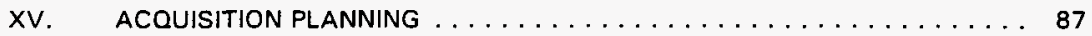

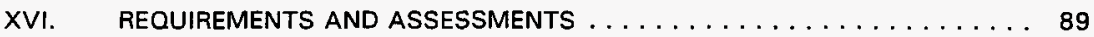

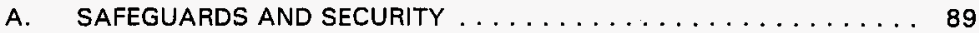

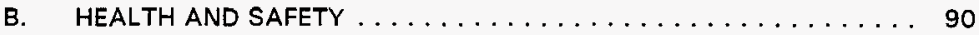

C. DECONTAMINATION AND DECOMMISSIONING ........... 91

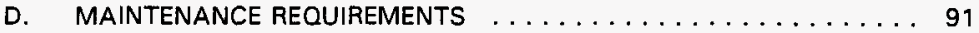

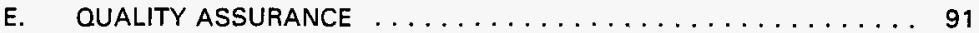

F. ENVIRONMENTAL COMPLIANCE $\ldots \ldots \ldots \ldots \ldots \ldots \ldots \ldots$

G. ENVIRONMENTAL DOCUMENTATION AND PERMITS $\ldots \ldots \ldots \ldots . . . .$.

H. DESIGN COMPLIANCE ................... 94

XVII. IDENTIFICATION AND ANALYSIS OF UNCERTAINTIES/

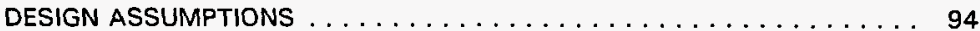

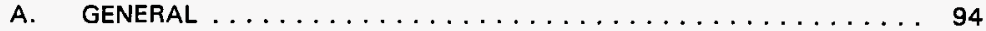

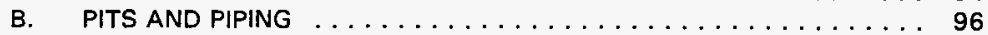

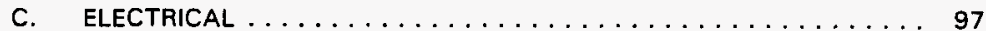

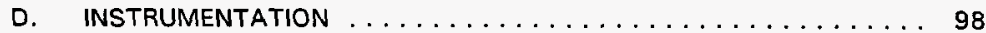

E. VENTILATION ........................ 100

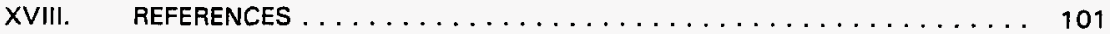




\section{APPENDICES}

Appendix A. Work Breakdown Structure

Appendix B. Budget Authorized/Budget Outlay Schedule

Appendix C. Cost Estimate Summary

Appendix D. Conceptual Project Schedule

Appendix E. Outline Specification

Appendix F. Energy Conservation Report and Analysis

Appendix G. Physically Handicapped Assessment

Appendix H. Unreviewed Safety Questions Evaluation

Appendix I. Permitting Plan

Appendix J. Plant Forces Work Review

Appendix K. Figures 


\section{ACRONYMS/ABBREVIATIONS}

\begin{tabular}{|c|c|}
\hline $\begin{array}{l}\text { ACD } \\
\text { AF } \\
\text { A-E } \\
\text { ALARA } \\
\text { ANSI } \\
\text { ASME } \\
\text { ASTM } \\
\text { AT }\end{array}$ & $\begin{array}{l}\text { advanced conceptual design } \\
\text { ampere frame } \\
\text { architect-engineer } \\
\text { as low as reasonably achievable } \\
\text { American National Standards Institute } \\
\text { American Society of Mechanical Engineers } \\
\text { American Society for Testing and Materials } \\
\text { ampere trip }\end{array}$ \\
\hline $\begin{array}{l}\text { BNFL } \\
\text { BOA }\end{array}$ & $\begin{array}{l}\text { British Nuclear Fuels, Ltd. } \\
\text { basic ordering agreement }\end{array}$ \\
\hline $\begin{array}{l}\text { CAM } \\
\text { CASS } \\
\text { CCS } \\
\text { CDR } \\
\text { CFR }\end{array}$ & $\begin{array}{l}\text { continuous air monitor } \\
\text { computer automated surveillance system } \\
\text { clean, control, and stable } \\
\text { conceptual design report } \\
\text { Code of Federal Regulations }\end{array}$ \\
\hline $\begin{array}{l}\text { DCBL } \\
\text { DCRT } \\
\text { DCS } \\
\text { DOE } \\
\text { DST } \\
\text { D\&D }\end{array}$ & $\begin{array}{l}\text { design configuration baseline } \\
\text { double-contained receiver tank } \\
\text { digital control system } \\
\text { United States Department of Energy } \\
\text { double-shell tank } \\
\text { decontamination and decommissioning }\end{array}$ \\
\hline $\begin{array}{l}E A \\
E / C\end{array}$ & $\begin{array}{l}\text { Environmental Assessment } \\
\text { Engineer/Constructor Contractor }\end{array}$ \\
\hline $\begin{array}{l}\text { F\&R } \\
\text { FONSI }\end{array}$ & $\begin{array}{l}\text { functions and requirements } \\
\text { finding of no significant impact }\end{array}$ \\
\hline $\begin{array}{l}\text { GEMS } \\
\text { GND }\end{array}$ & $\begin{array}{l}\text { gaseous effluent monitoring system } \\
\text { ground }\end{array}$ \\
\hline $\begin{array}{l}\text { HEPA } \\
\text { HPT } \\
\text { HVAC }\end{array}$ & $\begin{array}{l}\text { high-efficiency particulate air } \\
\text { health physics technician } \\
\text { heating, ventilating, and air conditioning }\end{array}$ \\
\hline $\begin{array}{l}\text { I/O } \\
\text { ICE } \\
\text { ICF KH } \\
\text { IEEE } \\
\text { ISA }\end{array}$ & $\begin{array}{l}\text { input/output } \\
\text { instrumentation/control/electrical } \\
\text { ICF Kaiser Hanford Company } \\
\text { Institute of Electrical and Electronic Engineers } \\
\text { Instrument Society of America }\end{array}$ \\
\hline JMN & justification of mission need \\
\hline KD & key decision \\
\hline
\end{tabular}


ACRONYMS/ABBREVIATIONS (cont.)

LATA

MCC

MMI

MPS

NEMA

NEPA

OC

OPC

OSHA

OTP

PDRD

PLC

QAPP

RCRA

RL

RTD

SACS

SCR

SE

SEPA

SSPP

SEMP

SST

TFLAN

TFRSO

TPC

TMACS

TWRS

USQ

USSR

WAC

WBS

WHC
Los Alamos Technical Associates

motor control center

man-machine interface

master pump shutdown

National Electric Manufacturer's Association

National Environmental Policy Act

operating contractor

other project cost

Occupational Safety and Health Administration

operational test procedure

preliminary design requirements document

programmable logic controller

Quality Assurance Program Plan

Resource Conservation and Recovery Act

U.S. Department of Energy, Richland Operations

Office

resistive temperature device

Surveillance Analysis Computer System

silicon controlled rectifier

systems engineering

State Environmental Policy Act

System Safety Program Plan

systems engineering management plan

single-shell tank

tank farm local area network

Tank Farm Restoration and Safe Operations

total project cost

tank monitor and control system

Tank Waste Remediation System

unreviewed safety question

Upgrade Scope Summary Report

Washington Administrative Code

work breakdown structure

Westinghouse Hanford Company 


\title{
CONCEPTUAL DESIGN REPORT \\ TANK FARM RESTORATION AND SAFE OPERATIONS
}

\author{
PROJECT W-314
}

\section{INTRODUCTION}

Underground tanks have stored radioactive liquid waste on the Hanford Site since the 1940s. There are 149 single-shell tanks (SSTs) and 28 double-shell tanks (DSTs) in 200-East and 200-West Areas containing these wastes (see Figures C-1, C-2, and C-3). (All figures are shown in Appendix K.) The Tank Waste Remediation System (TWRS) program was established to resolve tank safety issues and dispose of the tank wastes. Project W-314, "Tank Farm Restoration and Safe Operations" (TFRSO), provides essential tank farm infrastructure upgrades to support continued safe storage of existing tank wastes until the wastes can be retrieved and disposed of through follow-on TWRS program efforts. The SSTs are essentially stable and have been placed in a non-operational configuration awaiting future retrieval of their remaining wastes. Project W-314 focuses on capital improvements necessary to allow continued safe operation of the existing DST facilities, double-contained receiver tanks (DCRTs), and selected SST systems.

This report was prepared using the conceptual design report (CDR) format defined in U.S. Department of Energy (DOE) Order 4700.1 (ref 1). The CDR provides the conceptual-level project scope and cost and schedule data needed to support validation of project W-314, a Major System Acquisition. Key Decision O (KD-0). "Approval of Mission Need," for project W-314 was approved by DOE in February 1995. The U.S. Department of Energy, Richland Operations (RL) request for KD-1, "Approval of New Start," is planned to be submitted following completion of the conceptual design.

Project W-314 includes instrumentation replacement, ventilation system replacement, piping additions, pit modifications, and electrical power upgrades. 
The upgrades focus on the DST system in 200-East Area, but also include SY Tank Farm in 200-West Area, 244-A and 244-S DCRTs, new transfer lines in 200-East Area, and minor improvements in the SST farms.

The scope of the project W-314 CDR effort is defined by the Upgrade Scope Summary Report (USSR) (ref 2). The USSR was prepared as part of a systems engineering process. It identifies the scope items (including systems, subsystems, and/or components) to be upgraded. The USSR was included in the project $W-314$ baseline as a key element to define the scope on which to develop this CDR.

An engineering report for project $W-314 G$ describes the conceptual design, cost estimate, and schedule for upgrades to the 241-AW Tank Farm (ref 3). The report was used to determine a technical, cost, and schedule basis from which to develop a reliable baseline for project $W-314$. Project $W-314 \mathrm{G}$ upgrades for the AW Tank Farm are similar to those discussed in this CDR. Project W-314G was used to establish fiscal year (FY) 97 budgets for project W-314. This CDR supersedes the project $W-314 G$ engineering report.

A systems engineering (SE) based approach is underway, concurrently with this CDR, to prepare a detailed and fully integrated conceptual design for project $W-314$. The conceptual design will be documented in the form of a Design Configuration Baseline (DCBL) package, as defined by the project systems engineering statement of work (SE-SOW) (ref 4). The design solutions in this CDR are to be confirmed or superseded upon completion of the project $W-314$ DCBL. Any differences in scope, cost, or schedule between this CDR and the completed DCBL will be reconciled prior to KD-1 and the start of definitive design. This CDR allows the project to proceed through the FY98 validation process while the DCBL package is being completed.

A description of the scope and requirements for the project $W-314$ upgrades is presented starting in Section IV of this report. The cost estimate summary and conceptual project schedule are shown in Appendices $C$ and $D$, respectively. 


\section{SUMMARY}

Project W-314 will provide upgrades to the ventilation systems, instrumentation and control system (including master pump shutdown circuitry), electrical support systems, and waste transfer systems support structure for identified double-shell tank (DST) farms, double-contained receiver tanks (DCRTs), and single-shell tank (SST) farms.

The existing primary ventilation systems for Tank Farms 241-AP, -AN, and -AW will be upgraded. New high capacity exhaust air clean-up trains, a new stack, stack monitoring and control equipment, and electric power will be provided. Concrete shielding walls will be constructed around the perimeter of the tank exhaust trains. These new systems will also be designed to allow for future installation of additional effluent control equipment. The existing primary tank exhaust trains will be removed and properly disposed. All existing underground annulus and primary ventilation piping will be reused.

New annulus ventilation equipment will be provided for the SY Tank Farm, and new ventilation systems will be provided for the 244-A and 244-S DCRTs.

New seal pots and associated encased piping will be installed in Tank Farms 241-AP, -AN, and -AW to collect condensate from the ventilation systems and return it to the primary tank collection system.

The existing primary tank monitoring will be modified and upgraded for level, temperature, and vapor pressure measurement. The waste transfer system will be upgraded for route verification and waste transfer verification. The leak detection system will be upgraded for the annulus, leak detection pit, and process and other support pits. The master pump shutdown system will be upgraded. The existing alarm systems will be upgraded.

Primary ventilation instrumentation for all DSTs will be upgraded. New ventilation systems and associated instrumentation will be provided. 
Existing power for the primary ventilation system will be modified and upgraded to provide backup power capabilities for Tank Farms 241-AP, -AN, and -AW. Existing electrical equipment will be upgraded and/or replaced to support the primary/annulus ventilation system of the DSTs, DCRTs, and electrical power for SSTs for clean, control, and stable operation.

New valve manifold assemblies will be provided to identified pits used for waste transfer operations. New transfer piping will be added to the A Tank Farm complex in 200-East Area and three existing transfer lines will be replaced.

Pits used for waste transfer operations associated with DST farms will have a special protective coating applied to the walls, floor, and underside of the cover blocks of each pit. This coating will provide a decontaminable surface and bring the pits into regulatory compliance.

Project W-314 will interface with on-going and future projects. On-going projects (i.e., projects $W-211, W-030$, and $W-058$ ) have been utilized for input into the design, estimate, and schedule.

The total project cost for this fiscal year 1997 Major System Acquisition project is estimated to be $\$ 273,000,000$.

\section{JUSTIFICATION}

Project $W-314$ was established to upgrade various systems in the tank farms on the Hanford Site. Many of the existing systems are not adequate enough to support continued safe management of the tank waste until the end of the Hanford TWRS mission (i.e., the year 2028). The discrepancies in the various systems include lack of compliance with current codes and regulations, equipment degradation, and operational inadequacy as listed in Appendix $C$ of the USSR.

To determine the scope of this project, a systems assessment was performed on the tank farm systems. The assessments are documented in references 5 , 
6, and 7. The systems were assessed against the technical requirements in the Preliminary Design Requirements Document (PDRD) (ref 8 ) to determine if the systems can fulfill current requirements. The systems were assessed for material condition and verification of operational performance for the remaining life of the tank farms. The systems and components that failed the systems assessment criteria were identified as being in the scope of project W-314 for upgrade and/or replacement. The identified scope of project $W-314$ is documented in the USSR.

This CDR provides descriptions of system enhancements that will provide continued safe operation, greater reliability, operational flexibility, and compliance to applicable codes and regulations for tank farm operations.

\section{DESCRIPTION OF PROJECT SCOPE FOR AN TANK FARM}

This section describes the electrical, instrumentation and control, ventilation, valve manifold, and protective coating upgrades to be provided for the AN Tank Farm. Specific material and equipment information is in the outline specification (see Appendix E).

\section{A. UTILITIES (600)}

\section{Electrical Service}

The electrical upgrades for the AN Tank Farm include the following (see

Figure $\mathrm{E}-1$ ):

- A 480 Vac, 3-phase, 3-wire, $60 \mathrm{~Hz}$ power system shall be provided to the primary ventilation system from the existing motor control center (MCC) EDS-MCC-102 which is fed from the existing MCC EDS-MCC-101 in the 241-AN-271 Building. A new circuit breaker will be installed in EDS-MCC-102 (compartment $\mathrm{C} 1$ ) rated 100 Ampere Frame (AF)/100 Ampere Trip (AT), 3-pole, 600 Vac to feed two enclosed combination magnetic starters and mini-power centers for the primary ventilation system. A mini-power center will 
be installed to supply $120 \mathrm{Vac}$ power to a new instrumentation and control panel.

- A new power receptacle will be provided for connection of an existing portable diesel generator set as a backup power source to the primary ventilation system to allow preventative maintenance on electrical equipment as needed.

- A main circuit breaker for switchgear 241-AN-US rated for 1200AF/1000AT, 3-pole, $600 \mathrm{Vac}, 42$ kAIC RMS symmetrical amperes will be procured as a backup spare breaker so that the existing breaker can be maintained, tested, and calibrated to ensure acceptable performance of the device. This power circuit breaker will be a drawout type with time/current characteristics of a long delay time pickup range from 0.5 to 1.25 times sensor rating and a short delay time pickup range from 2.0 to 10.0 times sensor rating.

- The existing cathodic protection system will be modified to accommodate and protect new underground ventilation and process piping against galvanic corrosion. New anodes, test stations, anode distribution and junction boxes, permanent reference electrodes, and cables will be provided as required.

- The new primary ventilation system will be bonded to a new ground grid that will be connected from the existing tank farm ground grid.

- Freeze protection for the primary ventilation drainage system will be provided. The $120 \mathrm{Vac}$ power for the freeze protection will be supplied from the mini-power center. 


\section{B. SPECIAL EQUIPMENT AND PROCESS SYSTEMS (700)}

\section{Instrumentation and Control}

\section{Primary Tank}

- Liquid Level: Displacement liquid level gages have been installed on Tanks 241-AN-103, -104, and -105. The analog output transmitter cards on these tanks will be replaced by a digital transmitter card. The signal will connect to a multiplexer/interface box in the 241-AN-271 Building. The level signals will be input to the tank farm local area network (TFLAN) programmable logic controller (PLC). Displacement liquid level gages will be installed on Tanks 241-AN-102, -106, and -107 with a digital transmitter card and will be connected to the 241-AN-27.1 multiplexer/interface box and the TFLAN PLC. A displacement level gage will be installed on Tank 241-AN-101 by the A-101 stabilization project.

- Liquid Level High Alarm: The current/conductivity high liquid level probe will be replaced with a system similar to the resistive/conductivity liquid presence detectors in the annulus. A fixed probe will sense a high tank liquid level. The high liquid level alarm will be an intrinsically safe system. The high-level alarm signal will be connected to a local TFLAN input/output $(1 / O)$ box.

- Waste Temperature: A new waste temperature measurement device will be installed on Tanks 241-AN-101, -102, -106, and-107. Temperature measurement devices for Tanks 241-AN-103, -104, and -105 have been or will be installed by other projects. A local terminal box will be installed at the device to collect the signal wires which will be wired in parallel to the tank monitor and control system (TMACS) and to a local TFLAN $1 / O$ box. 
- Vapor Space Pressure: The high and low range pneumatic transmitters located in the transmitter enclosures next to the leak detection pit for each tank will be replaced by electronic indicating pressure transmitters. Analog signals will be wired to a local TFLAN I/O box.

\section{Waste Transfer}

- Valve Positioning: To provide verification of the waste transfer route prior to the initiation of a transfer, valve position indicators will be added to the new and existing valves located throughout the waste transfer system. The indicators will provide a position indication locally and a signal to a local TFLAN 1/O box allowing operations to confirm proper valve positioning. The upgrade is required in valve pits $241-\mathrm{AN}-\mathrm{A}$ and $-\mathrm{B}$, and pump pits AN-01A through -07A.

- Monitoring: Waste transfer will be measured for flow using magnetic flowmeters on the incoming and outgoing transfer lines associated with each DST. The incoming and outgoing lines are located within the central pump pits on top of each tank.

- Raw Water Flow Measurement: The flow meter in the service pit will be replaced by a turbine flowmeter. The signal will be wired to an AN Farm TFLAN I/O box and transmitted over the TFLAN network to the new TFLAN PLC in the 242-A Evaporator Building (242-A) where the signal will be output to the existing 242-A digital contral system (DCS) input.

\section{Leak Detection}

- Tank Annulus Liquid Presence Detectors: Three resistive/ conductivity leak detectors will replace existing detectors on each tank. The liquid presence detector will be an intrinsically 
safe system. The new leak detection signals will be connected to a local TFLAN I/O box.

- Tank Annulus Exhaust Air Leak Detector: The existing continuous air monitor (CAM) radiation detectors installed in each tank annulus exhaust ventilation system will be replaced with updated instrumentation of the same type. The CAM radiation level signal will be connected to a local TFLAN I/O box.

- Leak Detection Pit, Gamma Radiation Monitor: Submersible gamma probes will replace the existing non-submersible probes for each leak detection pit guide tube (see Figure 1-2). The probe electronics and transmitter will be located in the transmitter enclosure. The system will detect, transmit to a local TFLAN I/O box, and alarm a specified rise in the gamma radiation field above the observed background.

- Leak Detection Sump, Liquid Leak Detector: A resistive/ conductivity leak detector will be installed in each dry sump (see Figure 1-2). A pump will be placed in the sump with tubing extending to the surface. If a leak is detected, the pump will be run manually to obtain a liquid sample for determination of liquid density by laboratory analysis. The leak alarm signal will be input to a local TFLAN I/O box.

- Process Pits: The existing current/conductivity leak detectors in the following pits will be replaced with new resistive/ conductivity leak detectors. The leak detector assemblies will be designed for permanent installation in a fixed location. The leak detection in the central pump pits will be an intrinsically safe system. New leak detectors will be connected to a local 
TFLAN 1/O box. Leak detectors will be installed in the following pits:

- Central (tank) pump pits 01A-07A

- Tank annulus pump pits 01B-07B

- Leak detection pit 01C-07C

- Valve pits 241-AN-A and -B

- Flush pit

- Service pit

- Condensate receiver pit 241-AN-01D

- Supernatant receiver pit 241-AN-01E

- Drain pit (W-314 installed)

- Cleanout Boxes: New resistive/conductivity type leak detectors will be installed in the nine AN Tank Farm cleanout boxes to replace the existing current/conductivity leak detectors. The leak detector assemblies will be designed for permanent installation in a fixed location (see Figures P-1, P-6, and $P-14$ ). The new leak detection signals will be input to a local TFLAN I/O box.

- Pipeline Leak Detectors (see Figure 1-3): Transfer line encasement pipe will be monitored for leaks at the test riser or in the encasement drain as appropriate. If existing test risers (i.e., swab risers) are used, they will have a permanent leak detector installed. If the drain pipe encasement is used, it will have a valve added (if needed) and a leak detector installed in the drain pipe located inside the connected process pit. New resistive/conductivity type leak detectors will be installed and the leak detection signals will be input to a local TFLAN I/O box. Pipeline leak detectors will be replaced or installed at the 
following pipeline encasement terminations (the numbers shown are totals for the tank farm):

- Tank annulus pump pits (7)

- Leak detection pit pump pits (7)

- Valve pit 241-AN-A (2)

- Valve pit 241-AN-B (existing) (2)

- Valve pit 241-AN-B (project W-314 installed encasement drain) (1)

- Drain pit (project W-314 installed drain lines) (3)

- Primary exhaust duct encasement lexisting exhaust duct to train) (1)

\section{Master Pump Shutdown (MPS)}

Reference section XIII.C.1, "Instrumentation and Control," for a complete discussion of the TFLAN and MPS. Inputs to the MPS are made locally through remote TFLAN I/O boxes distributed throughout the tank farm or directly to the PLC in the Instrument Building. These MPS input signals are available to any connected TFLAN and the TMACS. The existing tank farm inputs and outputs to and from the MPS are listed in Table 1.

TABLE 1

\begin{tabular}{||l|l|}
\hline \multicolumn{1}{|c|}{ AN TANK FARM - MPS SIGNALS } \\
\hline Signal Type & \multicolumn{1}{|c|}{ Description } \\
\hline Input & Pit leak detectors \\
\hline Input & Cleanout box leak detectors \\
\hline Input & Transfer pipe encasement leak detectors \\
\hline Output & Supernatant pumps \\
\hline
\end{tabular}

Ventilation, Primary Exhaust (see Figure $\mathrm{H}-1$ )

- Inlet Pressure: The exhaust train inlet manifold pressure will be measured with respect to atmosphere. The pressure sense 
tap will be a fitting on the duct. The sensing tubing will be routed to a local instrumentation rack (one near each exhaust train) for connection to an indicating transmitter. The analog signal from the transmitter will be wired to the local TFLAN I/O box.

- Differential Pressure Measurements: The demisters lone for each train), HEPA filters (two for each train), and exhaust fan (one for each train) differential pressures will be measured. The sensing taps will consist of a fitting on the exhaust train housing on each side of the device measured and taps will be provided for the future equipment. The sensing tubing will be routed to a local instrument rack for connection to the indicating transmitter. The analog signals from the transmitters will be wired to the local TFLAN $1 / 0$ box.

- Exhaust Train Temperatures: Train inlet, heater outlet, and train outlet temperatures will be measured. Temperature elements will be installed in wells mounted on the exhaust train housing in front of the demister, immediately downstream of the heater, and downstream of the last filter. The temperature element will be wired to temperature indicating transmitters (three for each train/rack) on the local instrument rack. The analog signals from the transmitters will be wired to the local TFLAN I/O box.

- Exhaust Heater: A silicon controlled rectifier (SCR) unit will be installed next to the exhaust train heater in a National Electric Manufacturer's Association (NEMA) 4 enclosure. The heater controller will be a solid state device, controlled by an analog signal from the local TFLAN I/O box. Power to the heater controller will be interrupted, both locally or remotely, by either operating a manual on/off switch or deactivating a permissive interlock wired from the local TFLAN $1 / 0$ box. 
- Valves: Exhaust train valve motors (three for each train) will be wired to a switched (open/closed) signal from the local TFLAN $1 / O$ box through an interposing relay.

- Fan Inlet Damper Motor: The damper motor controller will be wired to an analog control signal from the TFLAN I/O box.

- Seal Pot Level (see Figure H-5): The condensate drain pit seal pot liquid level will be measured. Three resistive/conductivity probes will be installed at different levels in the seal pot: one for low level, one for fill level, and one for high level. The signal will be displayed locally and will be wired to a local TFLAN I/O box.

- Stack Monitor: A new exhaust stack radiation monitoring system will be procured and installed for the tank farm primary ventilation stack. Design and construction will consist of installing the specified sample and stack flow and temperature measurement probes in the stack, a stack mounted equipment box, and an electronics cabinet on a concrete pad near the stack. Stack flow and temperature, all sample flows, and all radiation measurement signals and alarms will be transmitted to a local TFLAN I/O box.

\section{Alarms}

- General Local: All project specified AN Tank Farm signals are input directly to a TFLAN PLC or through an associated $1 / O$ box. Analog signals and alarms are displayed locally on the man-machine interface (MMI).

- Gamewell Alarms: All necessary Gamewell alarms originating in the AN Tank Farm will be connected to the TFLAN PLC. The leak detection and MPS system is discussed in Section XIII. 
- 242-A DCS: The AN Tank Farm instruments that are scheduled for upgrade and are currently input to the 242-A DCS will be transmitted over the TFLAN network from the AN Tank Farm PLC to a new 242-A TFLAN PLC where they will be output to the 242-A DCS.

- TMACS: The TMACS-connected primary waste temperature signals will remain connected to the TMACS system and will also be connected to a TFLAN I/O box.

\section{Miscellaneous Signal Inputs}

Alarms, such as the 241-AN-271 Building general alarm, that are wired to the 242-A DCS will be rewired to the TFLAN PLC. The signals will be transmitted over the TFLAN network to the new 242-A TFLAN PLC where they will be output to the existing 242-A DCS.

\section{TFLAN System Components}

- PLC: The PLC, which will be located in the 241-AN-271 Building, will receive input and output signals from field devices, communicate with other devices using various digital protocols, and control outputs based on inputs and algorithms.

The PLC will contain hardware for analog signals such as current loop (4-20 $\mathrm{mA}$ ) voltage, thermocouples, and resistive temperature devices (RTDs), and discrete signals such as relays and on/off voltage devices.

The PLC will communicate with remote located I/O boxes, the MMI, and other PLCs. Communication to the I/O boxes will be via a serial digital transmission protocol that passes simple signal information. Communication with the MMI will be with an RS-232 or similar serial protocol for sending signal 
information to the MMI on demand. The PLC will communicate with the other PLCs using a communications protocol to share field signals and MPS data.

The PLC uses inputs and programmable functions such as averaging, totalizing, and timing to control outputs.

- MMI: The MMI will be an industrial quality computer with a display, limited capability front panel keypad, and hard disk drive. The MMI will input selected data from the PLC, perform calculations on and/or store the data, and communicate the data on demand to the TMACS using a modem. The MMI will display alarms and signal data on its display for the tank farm it is located in or for any data available on the TFLAN network. The MMI will be located in the 241-AN-271 Building.

- 1/O Box: The 1/O box will be a field located device that functions to extend the PLC input and output capability to field instrumentation. It will contain the hardware for analog and discrete input and output signals. Unlike the PLC, it cannot perform any other function and its communications will be limited to digital serial transmissions to the PLC over coaxial wire or through the TFLAN network. As often as possible, the $1 / O$ boxes will be located in the existing instrument enclosures at the leak detection pits. The enclosures will require the addition of heaters. Additional 1/O boxes will be located as needed to minimize conduit runs.

\section{Primary Ventilation System}

The existing ventilation system will be replaced to provide a new high capacity exhaust filter train, new fans, a new stack, stack monitoring and control systems, and provisions for possible future 
hazardous effluent mitigation equipment. Enhanced features of the new systems are as follows (see Figure $\mathrm{H}-1$ ):

- The new dual exhaust trains will consist of isolation valves, electric heaters, demisters with flush capability, two stages of HEPA filters, test sections, adsorber housing, automatic control dampers, and exhaust fans.

- Provisions for future equipment will be blanked flanges in the ventilation piping for a dry scrubber and empty housings in the filter trains for future carbon adsorbers.

- The new dual exhaust trains will be shielded by concrete walls and a removable metal roof. The new structure will not create an enclosure requiring ventilation.

- The new exhaust stack will be designed to enhance maximum dispersion of effluents, and will be provided with monitoring and sampling equipment required for regulatory compliance.

- Unfiltered leakage paths into the tanks will be sealed to reduce the potential for fugitive emissions and to improve pressure control of the primary tank air inlet stations (existing or by others). The extent of sealing will be similar to that provided for Tanks 241-AY and -AZ by Project W-030, "Tank Farm Ventilation Upgrade."

- A seal pot will be located in a new drain pit adjacent to the primary exhaust train. Condensate from the primary ventilation line and drains between the various exhaust filter housing sections will be routed to the seal pot. Condensate overflow from the seal pot will gravity drain back to an appropriate tank (see Figure $\mathrm{H}-5$ ). 
- The utilities (raw water) required for the seal pot and ventilation equipment will be provided from existing tank farm infrastructure.

- Existing underground ventilation piping will direct the flow from the tanks to the new equipment. The new equipment will be located as shown on Figure P-1.

- Primary air intake stations, one for each of the tanks, will consist of an air intake hood, a prefilter, a HEPA filter, HEPA filter test sections, connecting piping from the primary tank to the station, balancing valve, and pressure vacuum relief devices. This additional equipment will be provided by another project.

\section{Piping}

\section{Valve Manifolds}

Valve manifold assemblies (consisting of multiple jumpers) will be provided to support waste transfer operations in valve pits 241-AN-A and -B. The manifold will be constructed of stainless steel valves and piping to facilitate decontamination and to ensure long-term reliability. The manifold assembly will provide all necessary waste routing configurations by manual operation of valve handles that will extend through the pit cover blocks. See Figure P-18 for a typical representation of a valve pit manifold assembly. 
Manifold design will provide specifically for the following:

- Two-valve isolation from piping outside the desired flow path.

- Avoid trapping of liquids.

- The ability to cross-connect the slurry and supernatant transfer piping lines.

- The ability to flush all flow paths.

- Jumpers will utilize the Hanford integral seal block connection assembly.

The valve manifold will utilize valve designs that include the following:

- Manual operation of all valves through the use of extension handles that extend through the pit cover blocks.

- Position indication to provide verification of flow route alignment.

Each pit will be individually modified to provide access for the position indication signal provided with the valves. The signal connection to the valve position indicators is expected to be a plug and receptacle system that will allow removal of the individual jumpers while allowing the fixed conductor to remain in the pit (see Figure P-2 for a typical representation).

\section{Cover Blocks}

New cover blocks will be provided on valve pits 241-AN-A and -B receiving the new valve manifolds. The new cover blocks will accept the valve operating extension handles. The new jumper 
arrangements will be painted on the cover blocks to show the possible flow paths.

\section{Special Protective Coating}

The pits used in waste transfer operations will be lined. A special protective coating will be applied to the floors, the walls and the underside of the coverblocks of the pits. The procedure for coating requires the cleaning of the surfaces (without removing sound existing coating), filling all existing cracks with a grout material, priming the surface with a 5-mil thick coat of high solids epoxy, and finishing the surface with two 10-mil thick coats of an elastomeric coating. The following pits require this upgrade:

- Pump pits 241-AN-01A, -02A, -03A, -04A, -05A, -06A, and -07A - Valve pits 241-AN-A and -B

\section{DEMOLITION (810)}

The existing seal pot and all underground electrical systems, process piping, and ventilation piping that are to be replaced by project $W-314$ will be placed in a safe configuration and abandoned in place unless otherwise noted.

\section{Instrumentation and Control}

\section{Primary Tank}

- Liquid Level: For Tanks 241-AN-103,-104, and -105, the analog transmitter card in the liquid level instrument enclosure (on the tank riser) will be removed. For Tanks 241-AN-102, -106 , and -107 , the existing level measurement system will be removed.

- Liquid Level High Alarm: The probes will be removed from the tank risers. The associated relays and annunciators in the 241-AN-271 Building will be removed. 
- Temperature Trees: The existing trees and terminal boxes that are to be replaced will be removed. The instrument panel readouts will be removed in the 241-AN-271 Building.

- Tank Vapor Space Pressure: Both the low and high range pneumatic pressure transmitters and associated pneumatics will be removed (14 total). The instrument panel mounted pneumatic chart recorders and pneumatic to electrical alarm switches and the annunciators located in the 241-AN-271 Building will be removed.

\section{Waste Transfer}

- Raw Water Flow Measurement: The existing flow meter and associated readouts will be removed.

\section{Leak Detection}

- Tank Annulus Liquid Presence Detectors: Three liquid level tapes (i.e., flake boxes), the alarm switches, and the annunciator panel alarms in the 241-AN-271 Building will be removed.

- Tank Annulus Exhaust Air Leak Detector: The existing CAM system will be removed. The instrument panel annunciators and gages will be removed from the 241-AN-271 Building.

- Leak Detection Pit, Gamma Radiation Monitor: The existing Geiger-Mueller detector will be removed from the leak detection pit radiation well. The "power, pre-amp, count rate meter, and low count alarm" modules; the panel display; and the annunciator in the 241-AN-271 Building will be removed. The gamma monitor radiation detection well at the leak detection pit will be pumped dry. 
- Leak Detection Sump, Liquid Leak Detector: The leak detection pit transmitter cabinet contents (transmitter and tubing) will be removed from the instrument enclosure near the leak detection pit. The pneumatic alarm switches, the instrument panel weight factor and specific gravity readouts, and the annunciators located in the 241-AN-271 Building will be removed. The leak detection pump will be pumped dry.

- Process Pits Leak Detector: The leak detector, the service operating electrical cord, and the local relay/alarm box will be removed.

- Cleanout Box Leak Detectors: The leak detector, the service operating electrical cord, and the associated relay/alarm box will be removed.

- Pipeline Leak Detectors: The leak detector, the service operating electrical cord, and the current sensitive relay at the leak detection control station will be removed.

\section{Master Pump Shutdown}

Switches and wiring will be removed.

\section{Ventilation, Primary Exhaust}

All instrumentation associated with the primary exhaust ventilation train will be demolished with the ventilation train, including field-located aboveground equipment, conduit, and tubing. All associated relays, indicators, alarms, and recorders in the 241-AN-271 Building will be removed.

\section{Alarms}

- General Local: All instrumentation that has been replaced but is still wired to the TFLAN PLC will have its annunciator, 
indicator, and recorder removed from the main instrumentation panel in the 241-AN-271 Building.

- Gamewell: All relays and above ground wiring and conduit associated with the Gamewell signals that have been replaced will be removed. The Gamewell box will be removed from the 241-AN-271 Building.

\section{Miscellaneous Signal Inputs}

Relays, aboveground wiring and conduit, and annunciators will be removed.

\section{Ventilation Systems}

- The existing primary ventilation equipment will be removed and disposed of after the new ventilation equipment is in operation.

\section{Electrical}

- The feeders of the existing primary fan motors will be disconnected and removed.

\section{Piping}

- The existing jumpers and cover blocks located in the AN Valve Pits will be removed and disposed of accordingly.

- Debris will require disposal when the pits requiring special protective coating are examined and prepared for the upgrade.

\section{DESCRIPTION OF PROJECT SCOPE FOR AP TANK FARM}

This section describes the electrical, instrumentation and control, ventilation, and protective coating upgrades to be provided for the AP Tank Farm. Specific material and equipment information is in the outline specification. 
NOTE: For all references stating "Similar to the AN Tank Farm description" in this section, the AN text referring to the 241-AN-271 Building is changed to the 241-AP-271 Building.

\section{A. UTILITIES (600)}

\section{Electrical Service}

The electrical service upgrades for the AP Tank Farm are the same as described for the AN Tank Farm with the following differences (see Figure E-2):

- A main circuit breaker for the existing 1,000-kVA loadcenter unit substation will not be provided.

- A $120 \mathrm{~V}$ ground fault duplex receptacle in a weatherproof enclosure for the diesel generator battery charger will be provided. The receptacle will be fence-mounted outside at the southeast corner of the AP Tank Farm where the existing support equipment is stored. The receptacle will be fed from an existing panelboard EDS-DP-304 located inside the 241-AP-801 Water Service Building. A new $100 \mathrm{AF} / 20 \mathrm{AT}, 120 \mathrm{Vac}$, single-pole circuit breaker will be installed in space 7 of the panelboard.

\section{B. SPECIAL EQUIPMENT AND PROCESS SYSTEMS (700)}

\section{Instrumentation and Control}

\section{Primary Tank}

- Liquid Level: Similar to the AN Tank Farm description for replacement in all tanks.

- Liquid Level High Alarm: Similar to the AN Tank Farm description for all tanks. 
- Waste Temperature: Similar to the AN Tank Farm description for new installation in all tanks.

- Vapor Space Pressure: The pressure measurement 4-20 mA signal will be disconnected from the 241-AP-271 Building instrument panel chart recorder and reconnected to a local TFLAN I/O box.

Waste Transfer

- Valve Positioning: Similar to the AN Tank Farm description for valve pit 241-AP and the pump pits $01 \mathrm{~A}-08 \mathrm{~A}$ and $-02 \mathrm{D}$.

- Monitoring: Similar to the AN Tank Farm description.

- Raw Water Flow Measurement: Similar to the AN Tank Farm description for the service pit located within Service Building 241-AP-801.

\section{Leak Detection}

- Tank Annulus Liquid Presence Detectors: Similar to the AN Tank Farm description.

- Tank Annulus Exhaust Air Leak Detector: Similar to the AN Tank Farm description.

- Leak Detection Pit, Gamma Radiation Monitor: Similar to the AN Tank Farm description for leak detection pits $03 \mathrm{C}$ and $05 \mathrm{C}$ (see Figure 1-2).

- Leak Detection Sump, Liquid Leak Detector: Same as AN Tank Farm description for leak detection pits $03 \mathrm{C}$ and $05 \mathrm{C}$ (see Figure I-2). 
- Process Pits: Similar to the AN Tank Farm description for the following locations:

- Central (tank) pump pits 01A-08A

- Pump pit 02D

- Tank annulus pump pits 01B-08B

- Leak detection pit $03 \mathrm{C}$ and $05 \mathrm{C}$

- Valve pit 241-AP

- Mixer pump pits 07D, 07E, and 07F

- Jumper storage

- Flush pit

- Service pit in Service Building 241-AP-801.

- Drain pit 03D

- Drain pit (W-314 installed

- Pipeline Leak Detectors: Similar to the AN Tank Farm description for the following (the numbers shown are totals for the tank farm):

- Central (tank) pump pits (8)

- Tank annulus pump pits (8)

- Leak detection pit (2)

- Drain pit (W-314 installed drain lines) (3)

The valve pit has four existing risers outside the pit with current/conductivity leak detectors that will be replaced with resistive/conductivity leak detectors. The leak detection signals will be connected to a local TFLAN I/O box.

The encasement for pipeline $S N-650$ (on top of Tank 241-AP-102) will have the existing current/conductivity leak detector and relay replaced with a resistive/conductivity leak detector. The leak detection signal will be connected to a local TFLAN I/O box. 
WHC-SD-W314-CDR-001, Rev. 0

\section{Master Pump Shutdown}

Similar to the AN Tank Farm description except for those shown in Table 2.

TABLE 2

\begin{tabular}{|c|l|}
\hline \multicolumn{2}{|c|}{ AP TANK FARM - MPS SIGNALS } \\
\hline Signal Type & \multicolumn{1}{c|}{ Description } \\
\hline Input & Pit leak detectors \\
\hline Input & Pipe encasement leak detectors \\
\hline Input & Service and flush pit instrumentation \\
\hline Input & AP MPS hand switch in 242-A \\
\hline Output & Supernatant pumps \\
\hline
\end{tabular}

Ventilation, Primary Exhaust

Similar to the AN Tank Farm description.

\section{Alarms}

- General Local: Similar to the AN Tank Farm description.

- Gamewell Alarms: Similar to the AN Tank Farm description.

Miscellaneous Signal Inputs

Similar to the AN Tank Farm description.

\section{TFLAN and MPS System Components}

Similar to the AN Tank Farm description.

\section{Primary Ventilation System}

The primary ventilation system upgrades for the AP Tank Farm are the same as described for the AN Tank Farm (see Figures $\mathrm{H}-1$ and P-3). 
WHC-SD-W314-CDR-001, Rev. 0

\section{Piping}

\section{Special Protective Coating}

The coating upgrade for the AP Tank Farm is the same as described for the AN Tank Farm for the following pits:

- Pump pits 241-AP-01A, -02A, -03A, -04A, -05A, -06A, -07A, $-08 \mathrm{~A}$, and $-02 \mathrm{D}$.

- Valve pit 241-AP.

\section{DEMOLITION (810)}

The existing seal pot and all underground electrical systems, process piping, and ventilation piping that are to be replaced by project $W-314$ will be placed in a safe configuration and abandoned in place unless otherwise noted.

\section{Instrumentation and Control}

\section{Primary Tank}

- Liquid Level: Similar to the AN Tank Farm description for removal of the existing level measurement system for each tank riser.

- Liquid Level High Alarm: Similar to the AN Tank Farm description.

- Temperature Trees: Similar to the AN Tank Farm description except that the shared hardware and displays for the tank structure temperature will remain. The displays will be on the instrument panel in the 241-AP-271 Building.

- Tank Vapor Space Pressure: The 241-AP-271 Building chart recorder and high and low annunciator alarms will be removed. 
WHC-SD-W314-CDR-001, Rev. 0

\section{Waste Transfer}

- Service Pit Raw Water: The existing flowmeter and transmitter will be removed from the service pit. The flow indicator/totalizer will be removed from the 241-AP-271 Building panel.

\section{Leak Detection}

- Tank Annulus Liquid Presence Detectors: Similar to the AN Tank Farm description.

- Tank Annulus Exhaust Air Leak Detector: Similar to the AN Tank Farm description.

- Leak Detection Pit, Gamma Radiation Monitor: Similar to the AN Tank Farm description.

- Leak Detection Sump, Liquid Leak Detector: Similar to the AN Tank Farm description except that the added panel mounted level readout in the 241-AP-271 Building will be removed.

- Process Pits Leak Detectors: The service operating cord and element from the pit and the relay from the "LDK" relay enclosure in the 241-AP-271 Building will be removed. The leak detection and leak detection fail alarm annunciators from the instrument panel in the 241-AP-271 Building will be removed.

- Pipeline Leak Detectors: Similar to AN Tank Farm description including line SN-650.

\section{Master Pump Shutdown}

Similar to the AN Tank Farm description. 


\section{Ventilation, Primary Exhaust and Stack Monitor}

Similar to the AN Tank Farm description.

\section{Alarms}

- General Local: Similar to the AN Tank Farm description

- Gamewell: Similar to the AN Tank Farm description

- 242-A: Similar to the AN Tank Farm description

\section{Miscellaneous Signal INPUTS}

Similar to the AN Tank Farm description.

\section{Ventilation Systems}

- Demolition will be as described for the AN Tank Farm.

\section{Electrical}

- Demolition will be as described for AN Tank Farm.

4. Piping

- As described for the AN Tank Farm, debris is expected to be found in the pits needing special protective coating that will require disposal.

\section{DESCRIPTION OF PROJECT SCOPE FOR AW TANK FARM}

This section describes the electrical, instrumentation and control, ventilation, and protective coating upgrades to be provided for the AW Tank Farm. Specific material and equipment information is in the outline specification.

NOTE: For all references stating "Similar to the AN Tank Farm description" used in this section, the AN text referring to the 241-AN-271 Building is changed to the 241-AW-271 Building. 
WHC-SD-W314-CDR-001, Rev. 0

\section{A. UTILITIES (600)}

\section{Electrical Service}

The electrical service upgrades for the AW Tank Farm are the same as described for the AN Tank Farm with the following differences (see Figure E-3):

- A wire gutter, 100AF/100AT, 3-pole, $600 \mathrm{~V}$ enclosed circuit breaker, and a $3 \mathrm{kVA}$ mini-power center with $120 \mathrm{~V}$ ground fault receptacles will be installed on the diesel generator set. These items will be fed from the existing diesel generator set $600 \mathrm{~A}$ main breaker. At least $150 \mathrm{ft}$ of power cord ( $3 / \mathrm{C \# 2}$ and 1 \# GND) with a $100 \mathrm{~A}$ plug will be installed to provide power to the new primary ventilation backup power system. A minimum of four $120 \mathrm{~V}$ ground fault duplex receptacles will be installed on separate 20 A, 1-pole, $120 \mathrm{Vac}$ circuit breakers for maintenance of power tools. These receptacles will be fed from the mini-power center.

- The main circuit breaker for loadcenter unit substation C8S35 is rated for 600AF/600AT, 3-pole, $600 \mathrm{Vac}, 22 \mathrm{kAIC}$ RMS symmetrical amperes.

- Three new single-pole, 100 AF/20 AT, 600 Vac circuit breakers will be installed in existing panelboard " $A$ " located in the 241-AW-271 Building for instrumentation power requirements.

\section{B. SPECIAL EQUIPMENT AND PROCESS SYSTEMS (700)}

\section{Instrumentation and Control}

\section{Primary Tank}

- Liquid Level: Tanks 242-AW-101 and -104 have a displacement gage installed. New gages will be provided for Tanks 241-AW-102,-103,-105, and-106. A new multiplexer/ 
interface box that will connect the level signals to the TFLAN PLC will be provided in the 241-AW-271 Building.

- Liquid Level High Alarm: Similar to the AN Tank Farm description.

- Waste Temperature: Similar to the AN Tank Farm description for Tanks 241-AW-102, -103, -104, and -106. The temperature measurement device for Tanks 241-AW-101 and -105 will be installed by project $W-211$.

- Vapor Space Pressure: Similar to the AN Tank Farm description.

Waste Transfer

- Valve Positioning: Similar to the AN Tank Farm description for pits 241-AW-A and $-B$ and pump pits 01A through 06A. For pit $02 E$, the existing indicators will be utilized and the signals will be fed to the PLC.

- Monitoring: Similar to the AN Tank Farm description.

- Raw Water Flow Measurement: Similar to the AN Tank Farm description.

\section{Leak Detection}

- Tank Annulus Liquid Presence Detectors: Similar to the AN Tank Farm description.

- Tank Annulus Exhaust Air Leak Detector: Similar to the AN Tank Farm deșcription.

- Leak Detection Pit, Gamma Radiation Monitor: Similar to the AN Tank Farm description. 
- Leak Detection Sump, Liquid Leak Detector: Similar to the AN Tank Farm description.

- Process Pits: Similar to the AN Tank Farm description except for the following process pits:

- Central (tank) pump pits 01A-06A

- Tank annulus pump pits 01B-06B

- Leak detection pit 01C-06C

- Valve pits 241-AW-A and -B

- Flush pit

- Service pit

- $\quad$ Feed pump pit O2E

- Drain pit 02D

- Drain pit (W-314 installed)

- Cleanout Boxes: Similar to the AN Tank Farm description for 12 cleanout boxes (see Figures P-4 and P-16).

- Pipeline Leak Detectors: Similar to the AN Tank Farm description for the following (the numbers shown are totals for the tank farm):

- Feed pump pit O2E (2)

- Central pump pit O2D (2)

- Valve pit 241-AW-A (2)

- Valve pit 241-AW-A (W314 pipeline) (1)

- Valve pit 241-AW-B (2)

- Drain pit O2D (3)

- Drain pit (W-314 installed drain lines) (3) 
WHC-SD-W314-CDR-001, Rev. 0

\section{Master Pump Shutdown}

Similar to the AN Tank Farm description except for those listed in Table 3.

TABLE 3

\begin{tabular}{||c|c||}
\hline \multicolumn{2}{|c||}{ AW TANK FARM - MPS SIGNALS } \\
\hline Signal TYpe & $\quad$ Description \\
\hline Input & Pit leak detectors \\
\hline Output & Supernatant pumps \\
\hline Output & Tank 102 feed pump \\
\hline
\end{tabular}

Ventilation, Primary Exhaust

Similar to the AN Tank Farm description.

\section{Alarms}

- General Local: Similar to the AN Tank Farm description.

- Gamewell Alarms: Similar to the AN Tank Farm description.

Miscellaneous Signal Inputs

Similar to the AN Tank Farm description.

\section{TFLAN and MPS System Components}

Similar to the AN Tank Farm description.

\section{Primary Ventilation System}

The primary ventilation system upgrades for the AW Tank Farm are the same as described for the AN Tank Farm (see Figures $\mathrm{H}-1$ and P-4). 


\section{Piping}

\section{Special Protective Coating}

The coating upgrade for the AW Tank Farm is the same as described for the AN Tank Farm for the following pits:

- Pump pits 241-AW-01A, -02A, -03A, -04A, -05A,-06A, and-02E - Valve pits 241-AW-A and -B

\section{DEMOLITION (810)}

The existing seal pot and all underground electrical systems, process piping, and ventilation piping that are to be replaced by project $W-314$ will be placed in a safe configuration and abandoned in place unless otherwise noted.

\section{Instrumentation and Control}

\section{Primary Tank}

- Liquid Level: Similar to the AN Tank Farm description for removal of the existing level measurement for each tank riser.

- Liquid Level High Alarm: Similar to the AN Tank Farm description.

- Waste Temperature: Similar to the AN Tank Farm description except for Tank 241-AW-101 and -105.

- Vapor Space Pressure: Similar to the AN Tank Farm description.

\section{Waste Transfer}

- Raw Water Flow Measurement: Similar to the AN Tank Farm description. 


\section{Leak Detection}

- Tank Annulus Liquid Presence Detectors: Similar to the AN Tank Farm description.

- Tank Annulus Exhaust Air Leak Detector: Similar to the AN Tank Farm description.

- Leak Detection Pit, Gamma Radiation Monitor: Similar to the AN Tank Farm description.

- Leak Detection Sump, Liquid Leak Detector: Similar to the AN Tank Farm description.

- Process Pits: Similar to the AN Tank Farm description.

- Cleanout Boxes: Similar to the AN Tank Farm description.

- Pipeline Leak Detectors: Similar to the AN Tank Farm description.

Primary Ventilation

Similar to the AN Tank Farm description.

Alarms

- General Local: Similar to the AN Tank Farm description.

- Gamewell Alarms: Similar to the AN Tank Farm description.

Miscellaneous Signal Inputs

Similar to the AN Tank Farm description.

\section{Ventilation Systems}

- Demolition will be as described for the AN Tank Farm. 
WHC-SD-W314-CDR-001, Rev. 0

3. Electrical

- Demolition will be as described for the AN Tank Farm.

4. Piping

- As described for the AN Tank Farm, debris is expected to be found in the pits needing special protective coating that will require disposal.

\section{DESCRIPTION OF PROJECT SCOPE FOR AY TANK FARM}

This section describes the electrical, instrumentation and control, piping, and protective coating upgrades to be provided for the AY Tank Farm. Specific material and equipment information is in the outline specification.

NOTE: For all references stating "Similar to the AN Tank Farm" in this section, the AN text referring to the 241-AN-271 Building is changed to the 241-A-271 Building.

\section{A. UTILITIES $(600)$}

\section{Electrical Service}

The MCC-AY1 will be upgraded as follows:

- The existing MCC will be replaced with a new one to accommodate the existing load as shown on Figure E-4.

- The trip setting of the feeder breaker in compartment B1 in the existing switchgear feeding the MCC-AY1 will be changed from 600AT to 350AT to provide overcurrent protection to the existing feeder to MCC-AY1. The switchgear is located at Substation 241-A.

- Spare starters and spaces will be provided only in the assigned compartments as shown on Figure E-4. 
- A new mini-power center will be provided to supply $120 \mathrm{Vac}$ power to the new instrumentation equipment and control panel. This mini-power center will be fed from the new MCC-AY 1.

- An existing impressed current cathodic protection will be modified to protect new process underground piping against galvanic corrosion.

The existing HVAC control panels will be upgraded as follows (see Figure E-4):

- The existing HVAC control panel for Tank 241-AY-101 will be replaced.

- The existing HVAC control panel for Tank 241-AY-102 will be replaced.

- The existing heater controllers will be replaced with a new SCR unit.

\section{B. SPECIAL EQUIPMENT AND PROCESS SYSTEMS (700)}

\section{Instrumentation and Control}

\section{Primary Tank}

- Liquid Level: Similar to the AN Tank Farm description for replacement of instruments on Tank 241-AY-101 and -102. A multiplexer/interface box will be provided in the 241-AY-801 Building. The signal will connected to the TFLAN PLC. 
- Liquid Level High Alarm: Similar to the AN Tank Farm description except that the signal transmits to the 241-AY-801 Building.

- Waste Temperature: Similar to the AN Tank Farm description for Tanks 241-AY-101 and -102. The signals will be connected to the 241-AY-801 Building.

- Vapor Space Pressure: Similar to the AN Tank Farm description except that the signal transmits to the 241-AY-801 Building.

\section{Waste Transfer}

- Valve Positioning: Similar to the AN Tank Farm description for the central pump pits. The PLC and MMI are in the 241-AY-801 Building.

- Monitoring: Similar to the AN Tank Farm description.

- Raw Water Flow Measurement: Similar to the AN Tank Farm description for replacement at the 241-AX service pit.

\section{Leak Detection}

- Tank Annulus Liquid Presence Detectors: Similar to the AN Tank Farm description. The new detectors will be installed in spare risers.

- Tank Annulus Exhaust Air Leak Detector: Similar to the AN Tank Farm description.

- Leak Detection Pit, Gamma Radiation Monitor: Similar to the AN Tank Farm description for two leak detection pits. 
- Leak Detection Sump, Liquid Leak Detector: Similar to the AN Tank Farm description for two leak detection pits.

- Encasement Drain Pit, Gamma Radiation Monitor: Similar to the leak detection pit, except for the encasement drain pit. The encasement drain pit will have the same design as the leak detection pits.

- Encasement Drain Pit Sump, Liquid Leak Detectors: Similar to the leak detection pit except for the encasement drain pit sump. The encasement drain pit sump will have the same design as the leak detection sump.

- Process Pits: Similar to the AN Tank Farm description except for the following process pits:

- Central (tank) pump pits 01A and O2A

- Sluice pits 01B, 01C, 01D, 01E and 02B, 02C, 02D, O2E

- Tank annulus pump pits 01F and 02F

- Leak detection pits 101 and 102

- Encasement drain pit

- Cleanout Box: Similar to the AN Tank Farm description for one cleanout box (see Figure P-5).

- Pipeline Leak Detectors: Similar to the AN Tank Farm description for encasement leak detectors on risers, except that these leak detection signals will need to be transmitted parallel to the AY and AZ Tank Farms MICON DCS installed by project $W-030$. There are four AY Tank Farm encasement leak detectors on risers. An encasement leak detector is located at 241-AY-02A on the new $W-314$ transfer line from 241-AY-01D. 
WHC-SD-W314-CDR-001, Rev. 0

\section{Master Pump Shutdown}

Similar to the AN Tank Farm description except for those listed in Table 4.

\section{TABLE 4}

\begin{tabular}{||l|l||}
\hline \multicolumn{2}{|c|}{ AY TANK FARM - MPS SIGNALS } \\
\hline Signal Type & \multicolumn{1}{|c|}{ Description } \\
\hline Input & Pit leak detectors \\
\hline Input & Transfer pipe encasement leak detectors \\
\hline Output & Transfer pumps \\
\hline Output & Sluice pumps \\
\hline Output & Waste recovery pump \\
\hline
\end{tabular}

\section{Alarms}

- General Local: Similar to the AN Tank Farm description.

- Gamewell Alarms: Similar to the AN Tank Farm description except that the instrument building is $241-\mathrm{A}-271$.

\section{Miscellaneous Signal Inputs}

Similar to the AN Tank Farm description.

\section{TFLAN and MPS System Components}

Similar to the AN Tank Farm description except:

- The PLC and MMI will be installed in the 241-AY-801 Building.

- The signals will be forwarded to the 241-AY-271 Building PLC/MMI.

- The "MICON" system installed by project W-030 for the AY/AZ ventilation system will be modified to output selected 
primary ventilation signals to TMACS by the addition of a modem interface and programming.

- 242-A DCS: Similar to the AN Tank Farm description.

\title{
2. Piping
}

\begin{abstract}
Waste Transfer
Waste transfer line SL-504 will be replaced with an identical line (2-in. primary encased in 4-in. secondary) to support future waste transfer operations. SL-504 completes the waste transfer route from pit 241-AY-02A to pit 241-AY-01D. The new line is expected to parallel the existing slurry line and use the location of the wall nozzles currently used by SL-504 (see Figure P-5).
\end{abstract}

The wall nozzle connections for the replaced line will be upgraded to meet compliance criteria. The encasement currently stops on the outside of the pit wall and will be upgraded by extending the encasement to the inside wall of the pit.

\section{Special Protective Coating}

The coating upgrade for the AY Tank Farm is the same as described for the AN Tank Farm for the following pits:

- Pump pits 241-AY-01A and-02A.

- Sluice pits 241-AY-01B, -01C, -01D, -01E, -02B, -02C, -02D, and $-02 E$.

\section{DEMOLITION (810)}

All underground electrical systems and process piping will be replaced by project $W-314$ and will be placed in a safe configuration and abandoned in place unless otherwise noted. 


\section{Instrumentation and Control}

\section{Primary Tank}

- Liquid Level: Similar to the AN Tank Farm description for the level gages that are removed.

- Liquid Level High Alarm: Similar to the AN Tank Farm description except that the annunciators from the 241-AY-801 and 241-A-271 Buildings will be removed.

- Waste Temperature: Similar to the AN Tank Farm description except that the terminal box selector switch from the 241-AY-801 Building will be removed.

- Vapor Space Pressure: Similar to the AN Tank Farm except that the pneumatic to electronic signal converters and recorders to be removed are in the 241-AY-801 Building and the annunciators to be removed are in the 241-A-271 Building.

\section{Waste Transfer}

- Raw Water Flow Measurement: Similar to the AN Tank Farm description.

\section{Leak Detection}

- Tank Annulus Liquid Presence Detectors: Leak detector elements inside the annulus will be abandoned. Alarm relays and annunciators in the 241-AY-801 and 241-A-271 Buildings will be removed.

- Tank Annulus Exhaust Air Leak Detector: Similar to the AN Tank Farm description.

- Leak Detection Pit, Gamma Radiation Monitor: Similar to the AN Tank Farm description. 
- Leak Detection Sump, Liquid Leak Detector: Similar to the AN Tank Farm description except that the pneumatic to electric alarm switches and recorders are in the 241-AY-801 Building and the annunciators are in the 241-A-271 Building.

- Encasement Drain Pit, Gamma Radiation Monitor: Similar to the AN Tank Farm description for the leak detection pit.

- Encasement Drain Pit Sump, Liquid Leak Detectors: Similar to the AN Tank Farm description for the leak detection sump except that the pneumatic to electric alarm switches and recorders are in the 241-AY-801 Building and the annunciators are in the 241-A-271 Building.

- Process Pits: Similar to the AN Tank Farm description.

- Cleanout Box: Similar to the AN Tank Farm description.

- Pipeline Leak Detectors: Similar to the AN Tank Farm description.

\section{Master Pump Shutdown}

Similar to the AN Tank Farm description.

\section{Alarms}

- General Local: Similar to the AN Tank Farm description except for the 241-AY-801 and the 241-A-271 Buildings.

- Gamewell Alarms: Similar to the AN Tank Farm description for the 241-A-271 Building.

Miscellaneous Signal Inputs

Similar to the AN Tank Farm description. 
WHC-SD-W314-CDR-001, Rev. 0

\section{Electrical}

- The existing MCC-AY1 in the 241-AY-801 Building will be removed and disposed of accordingly. Existing conduit and wiring that do not require reconnection to the new MCC will be abandoned in place.

- The existing HVAC control panel for Tanks 241-AY-101 and -102 will be removed and disposed of accordingly.

- The existing heater controllers for Tanks 241-AY-101 and -102 will be removed and disposed of accordingly.

\section{Piping}

- As described for the AN Tank Farm, debris is expected to be found in the pits needing the special protective coating that will require disposal.

- Upgrading the pit wall nozzles will require minor modification of the pit wall to facilitate extension of the piping encasement.

- The existing slurry line SL-504 will be abandoned in place except for that portion required for placement of the new transfer line.

\section{DESCRIPTION OF PROJECT SCOPE FOR AZ TANK FARM}

This section describes the electrical, instrumentation and control, valve manifold, and protective coating upgrades to be provided for the $A Z$ Tank Farm. Specific material and equipment information is in the outline specification.

NOTE: For all references stating "Similar to the AN Tank Farm description" in this section, the AN text referring to the 241-AN-271 Building is changed to the 241-A-271 Building. 
WHC-SD-W314-CDR-001, Rev. 0

\section{A. UTILITIES (600)}

\section{Electrical Service}

The electrical upgrades for the AZ Tank Farm include the following:

- The existing EDS-MCC-704 will be replaced with a new MCC located inside the 241-AZ-801A Building as shown on Figure E-5.

- A new mini-power center will be provided to supply $120 \mathrm{Vac}$ power to the instrumentation equipment and control panel. This mini-power center will be fed from the new EDS-MCC-704.

- The existing EDS-MCC-703 and heater controllers will be replaced with new units as shown on Figure E-5A.

- An existing impressed current cathodic protection will be modified to protect new process underground piping against galvanic corrosion.

\section{B. SPECIAL EQUIPMENT AND PROCESS SYSTEMS (700)}

\section{Instrumentation and Control}

\section{Primary Tank}

- Liquid Level: Tank 241-AZ-101 has a displacement gage installed. A new gage will be provided for Tank 241-AZ-102. A new multiplexer/interface box will be provided in the 241-AZ-801 A Building that will connect the level signals to the TFLAN PLC.

- Liquid Level High Alarm: Similar to the AN Tank Farm description except that the signal transmits to the 241-AZ-801A Building. 
- Waste Temperature: Similar to the AN Tank Farm description for Tank 241-AZ-101. A waste temperature device for Tank 241-AZ-102 will be installed by project $W-211$. The signals are connected to the 241-AZ-801A Building.

- Vapor Space Pressure: Similar to the AN Tank Farm description except that the signal transmits to the 241-AZ-801 A Building.

\section{Waste Transfer}

- Valve Positioning: Similar to the AN Tank Farm description for sluice pit $A Z-02 B$ and the central pump pits. The PLC/MMI is in the 241-AZ-801A Building.

- Monitoring: Similar to the AN Tank Farm description.

\section{Leak Detection}

- Tank Annulus Liquid Presence Detectors: Similar to the AN Tank Farm description. The new detectors will be installed in spare risers.

- Tank Annulus Exhaust Air Leak Detector: Similar to the AN Tank Farm description.

- Leak Detection Pit, Gamma Radiation Monitor: Similar to the AN Tank Farm description for two leak detection pits.

- Leak Detection Sump, Liquid Leak Detector: Similar to the AN Tank Farm description for two leak detection pits.

- Encasement Leak Detection Pit 101/102, Gamma Radiation Monitor: Similar to the leak detection pit except for pit 101/102. Pit 101/102 will have the same design as the leak detection pits. 
- Encasement Leak Detection Pit 101/102 Sump, Liquid Leak Detectors: Similar to the leak detection sump except for pit 101/102. Pit 101/102 will have the same design as the leak detection pits.

- Process Pits: Similar to the AN Tank Farm description except for the following process pits:

- Central (tank) pump pits 01 A and 02A

- Siluice pits 01B, 01C, 02B, and 02C

- Annulus pump pits $01 \mathrm{~F}$ and $02 \mathrm{~F}$

- Leak detection pits 101 and 102

- Encasement leak detection pit 101/102

- Cleanout Boxes: Similar to the AN Tank Farm description for ten cleanout boxes (see Figures P-6 and P-15).

- Pipeline Leak Detectors: Similar to the AN Tank Farm description for encasement leak detectors on risers, except that the leak detection signals will need to be transmitted parallel to the AYIAZ Tank Farm MICON DCS installed by project $W-030$. The signals are as follows (the numbers shown are totals for the tank farm):

- $\quad A Z$ Tank Farm encasement leak detectors (on risers) (4)

- Sluice Pit 241-AZ-02B (project $W-314$ pipeline from 241-AX-A) (1) 


\section{Master Pump Shutdown}

Similar to the AN Tank Farm description except for those shown in Table 5 .

\section{TABLE 5}

\begin{tabular}{||c|l||}
\hline \multicolumn{2}{|c||}{ AZ TANK FARM - MPS SIGNALS } \\
\hline Signal Type & \multicolumn{1}{|c||}{ Description } \\
\hline Input & Pit leak detectors \\
\hline Input & Transfer pipe encasement leak detectors \\
\hline Output & Diverter station pump \\
\hline Output & Condensate pump \\
\hline Output & Annulus pumps \\
\hline Output & Transfer pumps \\
\hline Output & Sluice pumps \\
\hline Output & Waste recovery pumps \\
\hline
\end{tabular}

\section{Alarms}

- General Local: Similar to the AN Tank Farm description.

- Gamewell Alarms: Similar to the AN Tank Farm description except that the building is 241-A-271.

\section{Miscellaneous Signal Inputs}

Similar to the AN Tank Farm description.

\section{TFLAN and MPS System Components}

Similar to the AN Tank Farm description except:

- The PLC and MMI will be installed in the 241-AZ-801 A Building.

- The signals will be forwarded to the 241-A-271 Building PLC/MMI. 
- The "MICON" system installed by project W-030 for the AY/AZ ventilation system will be modified to output selected primary ventilation signals to TMACS by the addition of a modem interface and programming.

- 242-A DCS: Similar to the AN Tank Farm description.

\section{Piping}

\section{Valve Manifold}

The valve manifold assembly upgrade for the $A Z$ Tank Farm is the same as described for the AN Tank Farm and applies to sluice pit 241-AZ-O2B (see Figure P-7).

\section{Cover Blocks}

As described for the AN Tank Farm, new cover blocks will be provided for sluice pit 241-AZ-02B.

\section{Special Protective Coating}

The coating upgrade for the $A Z$ Tank Farm is the same as described for the AN Tank Farm for the following pits:

- Pump pits 241-AZ-01A and -02A

- Sluice pits 241-AZ-01B, -01C, -02B, and $-02 C$

\section{DEMOLITION (810)}

All underground electrical systems and process piping will be replaced by project $W-314$ and will be placed in a safe configuration and abandoned in place unless otherwise noted.

\section{Instrumentation and Control}

\section{Primary Tank}

- Liquid Level: Similar to the AN Tank Farm description except for the removal of annunciators at the 241-A-271 Building. 
- Liquid Level High Alarm: Similar to the AN Tank Farm description.

- Waste Temperature: Similar to the AN Tank Farm description except the terminal box selector switch in the 241-AZ-801A Building will be removed.

- Vapor Space Pressure: Similar to the AN Tank Farm description except that the pneumatic to electronic signal converters and recorders to be removed are in the 241-AZ-801 A Building and the annunciators to be removed are in the 241-A-271, Building.

\section{Leak Detection}

- Tank Annulus Liquid Presence Detectors: Leak detector elements inside the annulus will be abandoned. Alarm relays and annunciators in the 241-AZ-801A and 241-A-271 Buildings will be removed.

- Tank Annulus Exhaust Air Leak Detector: Similar to the AN Tank Farm description.

- Leak Detection Pit, Gamma Radiation Monitor: Similar to the AN Tank Farm description.

- Leak Detection Sump, Liquid Leak Detector: Similar to the AN Tank Farm description except that the pneumatic to electric alarm switches and recorders are in the 241-AZ-801A Building and the annunciators are in the 241-A-271 Building.

- Encasement Leak Detection Pit 101/102, Gamma Radiation Monitor: Similar to the AN Tank Farm description. 
- Encasement Leak Detection Pit 101/102 Sump. Liquid Leak Detectors: Similar to the AN Tank Farm description except that the pneumatic to electric alarm switches and recorders are in the 241-AZ-801A Building and the annunciators are in the 241-A-271 Building.

- Process Pits: Similar to the AN Tank Farm description.

- Cleanout Boxes: Similar to the AN Tank Farm description.

- Pipeline Leak Detectors: Similar to the AN Tank Farm description.

Master Pump Shutdown

Similar to the AN Tank Farm description.

Alarms

- General Local: Similar to the AN Tank Farm description except for the 241-AZ-801A and 241-A-271 Buildings.

- Gamewell Alarms: Similar to the AN Tank Farm description for the 241-A-271 Building.

Miscellaneous Signal Inputs

Similar to the AN Tank Farm description.

\section{Electrical}

- Demolition is as described for AY Tank Farm.

\section{Piping}

- As described for the AN Tank Farm, debris is expected to be found in the pits needing special protective coating that will require disposal. 
- The existing jumpers located in the $A Z$ sluice pit will be removed and disposed of accordingly.

- The existing cover blocks used for the $A Z$ sluice pit will be removed and disposed of accordingly.

\section{DESCRIPTION OF PROJECT SCOPE FOR SY TANK FARM}

This section describes the electrical, instrumentation and control, ventilation, and protective coating upgrades to be provided for the SY Tank Farm. Specific material and equipment information is in the outline specification.

NOTE: For all references in this section stating, "similar to the AN Tank Farm description," the AN text referring to the 241-AN-271 Building is changed to the project W-211 Instrumentation/Control/Electrical (ICE) Building at the SY Tank Farm.

\section{A. UTILITIES (600)}

\section{Electrical Service}

The electrical service upgrades for the SY Tank Farm are the same as described for the AN Tank Farm with the following differences (see Figure E-6):

- The spare main circuit breaker for the existing loadcenter substation will not be provided.

- Power for the annulus ventilation system will be upgraded as follows:

- Power to the two new 3-hp fans will be supplied for the annulus exhaust which will replace the existing 2-hp exhaust fans. 
- Power to the annulus supply heaters (two 1-kW heaters/tank) will be supplied for each of the three SY tanks.

- The existing circuit breaker in the C3A compartment of MCC-241-SY-271 in the 241-SY-271 Building will be replaced with a new circuit breaker rated at 100AF and 80AT.

- The existing \#8 AWG cable feeder from compartment C3A of MCC-241-SY-271 Building to the ventilation equipment power panel will be replaced with a $\# 4$ AWG cable to support the upgraded load.

- A new mini-power center will be provided to supply $120 \mathrm{Vac}$ power to the instrumentation equipment and control panel. This mini-power center will be fed from the new ventilation equipment power panel.

\section{B. SPECIAL EQUIPMENT AND PROCESS SYSTEMS (700)}

\section{Instrumentation and Control}

\section{Primary Tank}

- Liquid Level: Displacement gages exist on all tanks. A new multiplexer/interface box that will connect the level signals to the TFLAN PLC will be added in the 241-SY-271 Building.

- Liquid Level High Alarm: Similar to the AN Tank Farm description.

- Waste Temperature: New thermocouple trees will not be installed in the 241-SY Tank Farm. A new terminal will be installed near the TMACS terminals to allow for paralleling the existing temperature signal to the TFLAN PLC. 
- Vapor Space Pressure: Similar to the AN Tank Farm description.

\section{Waste Transfer}

- Valve Positioning: Similar to the AN Tank Farm description for pits 241-SY-A, -B; and the central pump pits.

- Monitoring: Similar to the AN Tank Farm description.

- Raw Water Flow Measurement: Similar to the AN Tank Farm description for the 241-SY-A flush pit. The signal will go to the TFLAN PLC in the 241-SY-271 Building.

\section{Leak Detection}

- Tank Annulus Liquid Presence Detectors: Similar to the AN Tank Farm description except that new detectors will not replace those existing at the same location.

- Tank Annulus Exhaust Air Leak Detector: Similar to the AN Tank Farm description.

- Leak Detection Pit, Gamma Radiation Monitor: Similar to the AN Tank Farm description.

- Leak Detection Sump, Liquid Leak Detector: Similar to the AN Tank Farm description.

- Process Pits: Similar to the AN Tank Farm description for the following process pits (the numbers shown are totals for the tank farm):

- Central (tank) pump pits 01A through 03A

- Tank annulus pump pits 01B through 03B

- Leak detection pits 01C-03C 
- Valve pits 241-SY-A and -B

- Flush pits 241-SY-A, -B, and -O2E

- Drain pit 241-SY-O2D

- Cleanout Boxes: Similar to the AN Tank Farm description for six boxes (see Figure P-8).

- Pipeline Leak Detectors: Similar to the AN Tank Farm description for the following leak detectors (the numbers shown are totals for the tank farm):

- Pump Pits: Two encasement drain line valves and two leak detectors per pit will be added (6).

- Annulus Pump Pits: A valve and leak detector will be added on the encasement (3).

- Leak Detection Pits: A valve and leak detector will be added on the encasement (3).

- Valve Pits: A valve and leak detector will be added for six encasements (6). 
WHC-SD-W314-CDR-001, Rev. 0

\section{Master Pump Shutdown}

Similar to the AN Tank Farm description except for those listed for 200-West Area in Table 6.

TABLE 6

\begin{tabular}{|c|l||}
\hline \multicolumn{2}{|c|}{ SY TANK FARM - MPS SIGNALS } \\
\hline Signal Type & Description \\
\hline Input & Pit leak detectors \\
\hline Input & Transfer pipe encasement leak detectors \\
\hline Input & 241-SY-271 hand switch \\
\hline Input & Miscellaneous from outside farm \\
\hline Output & Supernatant, leak detect pit, and annulus pumps \\
\hline Output & Slurry pump \\
\hline
\end{tabular}

\section{Ventilation, Primary}

The following existing instrumentation signals will be inputted to a local TFLAN I/O box.

- Inlet train pressure.

- Differential Pressure Measurements: The demister, prefilter, HEPA filters, and system pressure analog signals ( 5 total).

- Duct Heater Differential Temperature: The temperature indicator will be replaced with a temperature indicating transmitter.

- Primary ventilation stack monitor.

Ventilation, Annulus Supply (see Figure $\mathrm{H}-3$ )

- Differential Pressure Measurements: The prefilter (one for each train) and HEPA filter (one for each train) differential pressures will be measured. The sensing taps will be fittings on the exhaust train housing on each side of the device 
measured and taps will be provided for the future equipment. The sensing tubing will be routed to a local instrument rack for connection to the indicating transmitter. The analog signal from the transmitter will be wired to the local TFLAN I/O box.

- Inlet Train Temperatures: Train inlet, heater outlet, and train outlet temperatures will be measured. Temperature elements will be installed in wells mounted on the housing in front of the prefilter, immediately downstream of the heater, and downstream of the last filter. The temperature element will be wired to temperature indicating transmitters ( 3 each train/rack) on the local instrument rack. The analog signals from the transmitters will be wired to the local TFLAN I/O box.

- Heater: A heater controller will be installed next to the inlet train heater in a NEMA 4 or 12 enclosure. The heater element controller will be a solid state device controlled by an analog input from the local TFLAN I/O box. Power to the heater controller will be interrupted, both locally or remotely, by either operating a manual on/off switch or deactivating a permissive interlock wired from the local TFLAN $1 / O$ box.

Ventilation, Annulus Exhaust (see Figure $\mathrm{H}-2$ )

- Inlet Pressure: The inlet pressure will be measured with respect to atmosphere at the inlet of the exhaust train manifold. The pressure sensing tap will be a fitting on the duct. The sensing tubing will be routed to a local instrumentation rack (one near each exhaust train) for connection to an indicating transmitter. The analog signal from the transmitter will be wired to the local TFLAN I/O box.

- Differential Pressure Measurements: The prefilters lone each train) and the HEPA filters (one each train) differential pressures will be measured. The sensing taps will be a fitting 
on the exhaust train housing on each side of the device measured. The sensing tubing will be routed to a local instrument rack for connection to the indicating transmitter. The analog signal from the transmitter will be wired to the local TFLAN I/O box.

- Valves: Exhaust train valve motors (three each train) will be wired to a switched (open/closed) signal from the local TFLAN 1/O box through an interposing relay.

- Fan Inlet Damper Motor: The damper motor controller will be wired to an analog control signal from the TFLAN I/O box.

- Stack Monitor: Similar to the primary exhaust for the AN Tank Farm description.

\section{Alarms}

- General Local: Similar to the AN Tank Farm description.

- Gamewell Alarms: Similar to the AN Tank Farm description except the signals connect to CASS.

- 242-S: Alarms and signals normally sent to the 242-S control room will be transmitted to the project W-211 ICE Building at the SY Tank Farm.

Miscellaneous Signal Inputs

Similar to the AN Tank Farm description.

TFLAN and MPS System Components

Similar to the AN Tank Farm description. 


\section{Annulus Ventilation System}

The existing annulus ventilation system equipment will be replaced with an improved system. The following upgrades will be included:

- The new annulus exhaust system will have a higher capacity and will be divided into two units to allow backup capability during filter changeout or in the case of fan failure.

- The new equipment will consist of isolation valves, control valves, prefilters, HEPA filters, test sections, and fans with radial vane inlet dampers. A new stack and monitoring system will be provided (see Figure $\mathrm{H}-2$ ).

- The new annulus supply system will provide redundant air intake stations for each individual tank. Each station will incorporate an electric heater for frost protection, a prefilter, a HEPA filter, and an isolation valve. The air intake stations will replace the existing alternate annulus supply filter units connected to 8 -in. risers at each tank (see Figures $\mathrm{H}-3$ and P-8).

\section{Piping}

\section{Special Protective Coating}

The coating upgrade for the SY Tank Farm is the same as described for the AN Tank Farm for the following pits:

- Pump pits 241-SY-01A, -02A, -02E, and -03A

- Vaive pits 241-SY-A and -B

\section{DEMOLITION (810)}

All underground electrical systems and ventilation piping will be replaced by project $W-314$ and will be placed in a safe configuration and abandoned in place unless otherwise noted. 
WHC-SD-W314-CDR-001, Rev. 0

\section{Instrumentation and Control}

Primary Tank

- Vapor Space Pressure: Similar to the AN Tank Farm description.

\section{Waste Transfer}

- Raw Water Flow Measurement: Similar to the AN Tank Farm description.

\section{Leak Detection}

- Tank Annulus Liquid Presence Detectors: Similar to the AN Tank Farm description.

- Tank Annulus Exhaust Air Leak Detector: Similar to the AN Tank Farm description.

- Leak Detection Pit, Gamma Radiation Monitor: Similar to the AN Tank Farm description.

- Leak Detection Sump, Liquid Leak Detector: Similar to the AN Tank Farm description.

- Process Pits: Similar to the AN Tank Farm description.

- Cleanout Boxes: Similar to the AN Tank Farm description.

- Pipeline Leak Detectors: Similar to the AN Tank Farm description.

\section{Master Pump Shutdown}

Similar to the AN Tank Farm description.

Ventilation, Primary

- Duct Heater Differential Temperature: The existing temperature indicator will be removed for replacement. 
WHC-SD-W314-CDR-001, Rev. 0

\section{Ventilation, Annulus}

All instrumentation associated with the annulus exhaust ventilation train will be demolished with the ventilation train, including field located equipment, above ground wiring, conduit, tubing, and all associated equipment in the 241-SY-271 Building.

Alarms

- General Local: Similar to the AN Tank Farm description.

- Gamewell Alarms: Similar to the AN Tank Farm description.

Miscellaneous Signal Inputs

Similar to the AN Tank Farm description.

\section{Ventilation Systems}

- The existing annulus exhaust equipment and supply filter units (where new filter trains will be installed) will be removed and demolished.

\section{Electrical}

- The existing feeder circuit breaker of the MCC located in the 241-SY-271 Building will be removed.

- The existing feeder of the ventilation power panel will be disconnected and removed. The underground section of conduit and wiring will be abandoned in place.

4. Piping

- As described for the AN Tank Farm, debris is expected to be found in the pits needing the special protective coating that will require disposal. 


\section{DESCRIPTION OF PROJECT SCOPE FOR THE SST FARMS}

This section describes the electrical upgrades to be provided for SST Farms 241-A, -AX, -B, -BX, -BY-, -C, -T, -TX, -TY, -S, -SX, and -U. Specific material and equipment information is in the outline specification.

A. UTILITIES (600)

\section{Electrical Service (see Figure E-7, P-9, and P-10)}

- A new pad-mounted transformer rated at 75 kVA 1225 kVA for 241-C Tank Farm), $13.8 \mathrm{kV}-480 \mathrm{Y} / 277 \mathrm{Vac}$, 3-phase, 4-wire, $60 \mathrm{~Hz}$ will be provided to support a controlled, clean, and stable SST farm. This new transformer will be connected from the existing $13.8 \mathrm{kV}$ overhead line and will feed a new service distribution panelboard clean, control, and stable (CCS).

- A 480 Vac, 3-phase, 3-wire, $60 \mathrm{~Hz}$ power system will be provided from the new panelboard to refeed existing tank farm lighting and for maintenance and miscellaneous needs as required. A new mini-power center will be provided to supply $120 / 240$ Vac power for miscellaneous instrumentations such as the TMACS. The mini-power center will be fed from the new panelboard CCS.

- The new panelboard, power receptacle switches, and mini-power center will be mounted on a steel rack located in non-radiological zone inside the fence of the tank farm.

- A new enclosed circuit breaker rated 225AF/200AT, 600 Vac, 3-pole in a NEMA 4 enclosure will be provided to feed the existing C-LTG panel for C-Farm lighting. 


\section{DESCRIPTION OF PROJECT SCOPE FOR 244-A DCRT}

This section describes the electrical, instrumentation and control, and ventilation upgrades to be provided for the 244-A DCRT. Specific material and equipment information is in the outline specification.

NOTE: $\quad$ For all references stating "Similar to the AN Tank Farm description" used in this section, the AN text referring to the 241-AN-271 Building is changed to the 244-A instrument enclosure.

\section{A. UTILITIES $(600)$}

\section{Electrical Service (see Figure E-8 and P-12)}

- A new panelboard will be provided to replace the existing power distribution center located inside the 244-A instrument enclosure. This new panelboard will be fed from the existing MCC1 located at 242-A Building and will provide power to the new ventilation system; the existing load of the power distribution center; and the existing 244-A agitator, sump, and transfer pumps.

- A new mini-power center will be provided to supply $120 \mathrm{Vac}$ power to the instrumentation and control panel. This mini-power center will be fed from the new panelboard.

- The existing feeder of the power distribution center will be disconnected and removed from the existing 100AF/5OAT circuit breaker (compartment D5) of the MCC-2 located in 244-AR Building. The existing loads of the power distribution center will be disconnected, removed, and then reconnected to the new panelboard.

- A new 225AF/125AT, 3-pole, 600 Vac circuit breaker will be installed in compartment $\mathrm{B} 5$ of the existing MCC1 located in the 
242-A Building. A new feeder for the new panelboard will be installed.

- The existing feeders of the 244-A agitator, sump, and transfer pumps will be disconnected and removed from the existing MCC1 located in the 242-A Building. New feeders from the new panelboard will be installed.

\section{B. SPECIAL EOUIPMENT AND PROCESS SYSTEMS (700)}

\section{Instrumentation and Control}

\section{Primary Tank}

- Liquid Level: An existing spare riser on the 244-A DCRT tank will be extended through the pump pit cover block for installation of a displacement level gage. A multiplexer/ interface box will be installed in the instrument enclosure that will connect the level signal to the TFLAN PLC.

- Waste Temperature: Similar to the AN Tank Farm description.

- Vapor Space Pressure: The pressure transmitter will be replaced and the signal will be connected to the TFLAN PLC.

\section{Waste Transfer}

- Raw Water Flow Measurement: The flowmeter in the service pit will be replaced with a turbine flowmeter. The signal will be connected to the TFLAN PLC.

- Raw Water Radiation (Backflow) Detection: An "on line" liquid effluent radiation monitor in the service pit and an associated rate/count meter in the annulus enclosure assembly will be installed. An analog signal and fail alarms will be connected to the TFLAN. 


\section{Leak Detection}

- Tank Annulus Pump Pit Level: Similar to the AN Tank Farm description except that only one leak detector will be in the annulus.

- Tank Annulus Exhaust Air Leak Detector: Similar to the AN Tank Farm description except that the CAM will be inside the existing annulus enclosure assembly.

- Process Pits: Similar to the AN Tank Farm description for one pump pit.

- Pipeline Leak Detectors: Similar to the AN Tank Farm description for the following (the numbers shown are totals for the tank farm):

- 3-in. drain from flush pit to DCRT 244-A (1)

- 3-in. drain from diversion box 241-ER-153 to DCRT 244-A (1)

- SN-215 encasement (1)

- SN-216 encasement (1)

- WT-SNL-3150 encasement (1)

- WT-SLL-3160 encasement (1)

\section{Master Pump Shutdown}

Similar to the AN Tank Farm description for those in Table 7.

TABLE 7

\begin{tabular}{||l|l|}
\hline \multicolumn{2}{|c|}{ 244-A DCRT - MPS SIGNALS } \\
\hline Signal Type & \multicolumn{1}{|c|}{ Description } \\
\hline Input & 200-East MPS circuit \\
\hline Input & 244-A drain valve "V1" position \\
\hline Input & 244-A leak detector \\
\hline Output & Transfer pump P-244-A1 \\
\hline
\end{tabular}


WHC-SD-W314-CDR-001, Rev. 0

Ventilation, Supply System

Similar to the SY Tank Farm description (see Figure $\mathrm{H}-4$ for exceptions).

Ventilation, Exhaust System (see Figure $\mathrm{H}-4$ )

Similar to the SY Tank Farm description except that no demister differential pressure and inlet pressure instruments will be provided, and a stack monitor will not be installed by this project.

\section{Alarms}

- General Local: Similar to the AN Tank Farm description except that the existing Project W-058, "Replacement of Cross-site Transfer Pipelines," PLC will be used for connecting signals to the TFLAN.

- 242-A DCS: Similar to the AN Tank Farm description except that the existing project $\mathrm{W}-058$ PLC will be used to connect signals to the TFLAN.

\section{Miscellaneous Signal Inputs}

Similar to the AN Tank Farm description.

\section{TFLAN and MPS System Components}

Similar to the AN Tank Farm description except that the existing PLC installed by project $W-058$ will have a communications interface card added to connect to the TFLAN network. No TFLAN I/O boxes will be provided.

\section{Ventilation System}

The ventilation system will be replaced with new equipment and located above grade. The upgrades will be as follows:

- Outside air supply to the annulus will be provided through a system consisting of an intake plenum, an electric heater, a 
prefilter, a testable HEPA filter, and isolation valves. The equipment will be connected to the existing 6-in. inlet pipe supplying the annulus (see Figure $\mathrm{H}-4$ ).

- Exhaust equipment presently located in the filter pits will be removed and replaced with a new 4-in. jumper. The new above grade exhaust system will be connected to the existing 4-in. pipe exiting the pit. The new dual exhaust system will have $100 \%$ backup and will consist of motorized isolation valves, an electric heater, testable HEPA filters, housings for future carbon adsorbers, variable speed exhaust fans, and a stack with the provision of adding flow and record sample devices.

- The new dual exhaust trains will be protected by concrete shield walls and a removable metal roof (see figure P-11).

\section{DEMOLITION (810)}

All underground electrical systems and ventilation piping will be replaced by project $W-314$ and will be placed in a safe configuration and abandoned in place unless otherwise noted.

\section{Instrumentation and Control}

\section{Primary Tank}

- Liquid Level: The sensing legs into the tank that are fed by flow valves F1-TK-1 and F1-TK-2 will be removed. The specific gravity and weight factor transmitters and all associated aboveground tubing will be removed.

- Waste Temperature: The existing probe and associated transmitter will be removed.

- Vapor Pressure: The transmitter will be removed. 
Waste Transfer

- Raw Water Flow Measurement: The existing flowmeter will be removed.

- Raw Water Backflow Radiation Detector: The radiation detector, shielding and pig from the flush pit, associated electronics from the annulus enclosure assembly will be removed.

\section{Leak Detection}

- Tank Annulus Pump Pit Level: The three sensing legs into the annulus, the specific gravity and weight factor transmitters and their readouts will be removed.

- Tank Annulus Exhaust Air Leak Detector: The CAM, local electronics, and alarms from the annulus enclosure assembly will be removed.

- Process Pits: Similar to the AN Tank Farm description.

- Pipeline Leak Detectors: Similar to the AN Tank Farm description.

\section{Master Pump Shutdown}

Similar to the AN Tank Farm description.

\section{Ventilation, Inlet Train, Primary Exhaust Train}

All instrumentation associated with the existing inlet train and primary exhaust ventilation train will be demolished with the ventilation train, including field located equipment, above ground wiring, conduit and tubing, and all associated equipment in the instrument enclosure. 
WHC-SD-W314-CDR-001, Rev. 0

\section{Alarms}

- General Local: Similar to the AN Tank Farm description.

- 242-A DCS: Similar to the AN Tank Farm description.

Miscellaneous Signal Inputs

Similar to the AN Tank Farm description.

\section{Ventilation Systems}

- The existing ventilation equipment and piping will be removed and disposed of after the new ventilation systems are in operation.

\section{Electrical}

- The existing power distribution center located inside the 244-A instrument enclosure will be removed and disposed of as required.

- The feeder of the existing distribution center will be disconnected from the existing $\mathrm{MCC}-2$ located in the 244-AR Building. Exposed conduit and wiring will be removed, and underground conduit and wiring will be abandoned.

- The feeders of the existing 244-A agitator, sump, and transfer pumps will be disconnected from the existing MCC1 located in the 242-A Building. Exposed conduit and wiring will be removed, and underground conduit and wiring will be abandoned. 


\section{DESCRIPTION OF PROJECT SCOPE FOR 244-S DCRT}

This section describes the electrical, instrumentation and control, and ventilation upgrades to be provided for the 244-S DCRT. Specific material and equipment information is in the outline specification.

NOTE: For all references stating "Similar to the 244-A DCRT description" used in this section, the 244-A text referring to the 244-A instrument enclosure is changed to the 244-S instrument enclosure.

\section{A. UTILITIES (600)}

\section{Electrical Service (see Figure E-9)}

- A new pad-mounted transformer rated at 75 kVA, $13.8 \mathrm{kV}-480 \mathrm{Y} / 277 \mathrm{Vac}, 4-$ wire, $60 \mathrm{~Hz}$ will be provided to replace the existing 3-25 kVA, single-phase, pole-mounted transformers that are connected to the existing overhead $2.4 \mathrm{kV}$ line E8-L115. This new transformer will be connected to the existing overhead $13.8 \mathrm{kV}$ line C8L4 and will feed the existing service distribution panelboard "A" located inside the 244-S instrument enclosure.

- A new service metering and disconnect switch will be provided for the new service feeder to the existing panelboard.

- The existing $2.4 \mathrm{kV}$ lightning arresters, fuse cutouts, and existing feeder conductors to the existing panelboard will be removed.

- A 480 Vac, 3-phase, 3-wire, $60 \mathrm{~Hz}$ power system to the new DCRT ventilation system from the existing service distribution panelboard "A" will be provided. A new mini-power center will be provided to supply $120 \mathrm{Vac}$ power for the instrumentation and control panel. The mini-power center will be fed from the existing service distribution panelboard $A$. 
- A new enclosed circuit breaker rated 100AF/60AT, 600 Vac, 3-pole in a NEMA 4 enclosure will be provided to feed an existing panel in the 241-S-271 instrumentation and electrical control house.

\section{B. SPECIAL EOUIPMENT AND PROCESS SYSTEMS (700)}

\section{Instrumentation and Control}

Primary Tank

- Liquid Level: Similar to the 244-A DCRT description.

- Waste Temperature: Similar to the 244-A DCRT description.

- Vapor Space Pressure: Similar to the 244-A DCRT description.

Waste Transfer

- Raw Water Flow Assessment: Similar to the 244-A DCRT description for the flush pit.

- Raw Water Radiation (Backflow) Detection: Similar to the 244-A DCRT description for the flush pit.

\section{Leak Detection}

- Tank Annulus Pump Pit Level: Similar to the 244-A DCRT description.

- Tank Annulus Exhaust Air Leak Detector: Similar to the 244-A DCRT description.

- Process Pits: Similar to the 244-A DCRT description.

- Pipeline Leak Detectors: Similar to the 244-A DCRT description for the following encasements (the numbers shown are totals for the tank farm): 


$$
\begin{array}{ll}
- & \text { V456 (1) } \\
- & \text { V522(1) } \\
- & \text { V560 (1) } \\
- & \text { V561 (1) } \\
- & \text { V562(1) } \\
- & \text { Flush pit drain (1) } \\
-\quad \text { WT-SNL-5350-M17 (3) }
\end{array}
$$

\section{Master Pump Shutdown}

Similar to the 244-A DCRT description.

Ventilation, Supply System

Similar to the 244-A DCRT description.

Ventilation, Exhaust System

Similar to the 244-A DCRT description.

\section{Alarms}

- General Local: Similar to the 244-A DCRT description.

- Gamewell Alarms: Similar to the AN Tank Farm description except the signals are connected to the Gamewell in the 241-SY-271 Building.

- 242-S Control Room: All signals to the 242-S control room will be rerouted to the TFLAN MMI in the project W-211 ICE Building at the SY Tank Farm.

\section{Miscellaneous Signal Inputs}

Similar to the 244-A DCRT description. 
TFLAN and MPS System Components

Similar to the 244-A DCRT description except that a TFLAN PLC/MMI will be installed by project $W-314$ in the instrument enclosure.

\section{Ventilation System}

The upgrades to the 244-S DCRT are similar to those described for the 244-A DCRT (see Figures $\mathrm{H}-4$ and $\mathrm{P}-13$ ).

\section{DEMOLITION $(810)$}

All underground electrical systems and ventilation piping will be replaced by project $\mathrm{W}-314$ and will be placed in a safe configuration and abandoned in place unless otherwise noted.

\section{Instrumentation and Control}

\section{Primary Tank}

- Liquid Level: Similar to the 244-A DCRT description.

- Waste Temperature: Similar to the 244-A DCRT description.

- Vapor Pressure: Similar to the 244-A DCRT description.

Waste Transfer

- Raw Water Flow Measurement: The existing flowmeter will be removed.

- Raw Water Backflow Radiation Detector: Similar to the 244-A DCRT description.

\section{Leak Detection}

- Tank Annulus Pump Pit Level: Similar to the 244-A DCRT description. 
- Tank Annulus Exhaust Air Leak Detector: Similar to the 244-A DCRT description.

- Process Pits: Similar to the 244-A DCRT description.

- Pipeline Leak Detectors: Similar to the 244-A DCRT description.

\section{Master Pump Shutdown}

Similar to the 244-A DCRT description.

Ventilation, Inlet Train, Primary Exhaust Train

Similar to the 244-A DCRT description.

\section{Alarms}

- General Local: Similar to the 244-A DCRT description.

- Gamewell Alarms: Similar to the 244-A DCRT description.

- 242-S Control Room: The annunciators, displays, and recorders in the 242-S control room will be abandoned in place for the demolition of the 242-S Building.

Miscellaneous Signal Inputs

Similar to the 244-A DCRT description.

\section{Ventilation Systems}

- Similar to the 244-A DCRT description.

\section{Electrical}

- The existing three 25 kVA, single-phase, pole-mounted transformers including lightning arresters, fused cutouts, hardware, wires, and conduit will be disconnected and removed. 


\section{DESCRIPTION OF PROJECT SCOPE FOR 200-EAST/ 200-WEST AREAS}

This section describes the electrical, instrumentation and control, piping, valve manifold, and protective coating upgrades to be provided for the 200-East and 200-West Areas. Specific material and equipment information is in the outline specification.

\section{A. OTHER STRUCTURES (550)}

\section{Special Protective Coating}

The coating upgrade for the 200-East Area is the same as described for the AN Tank Farm for the following pits:

- Valve pits 241-A-A and $-\mathrm{B}$ and 241-AX-A and $-\mathrm{B}$

B. UTILITIES (600)

\section{Electrical}

\section{Cathodic Protection}

The existing rectifiers in Tank Farms 241-A, $-A X,-A Y$, and $-A Z$ will be modified to accommodate and protect the new process piping lines against galvanic corrosion. New anodes, test stations, anode distribution and junction boxes, permanent reference electrodes, and cables will be provided as required.

\section{SPECIAL EQUIPMENT AND PROCESS SYSTEMS (700)}

\section{Instrumentation and Control}

\section{Waste Transfer}

- Valve Positioning: Sirnilar to the AN Tank Farm description for valve pits 241-A-A, 241-A-B, 241-AX-A, and 241-AX-B. Position signals will be wired to the TFLAN PLC in the 241-A-271 Building. 


\section{Leak Detection}

- A and AX Tank Farm Pit and Encasement Leak Detectors: Similar to the AN Tank Farm description for 20 pit and pipeline leak detectors in the $A$ and $A X$ Tank Farms. Signals will be wired to the TFLAN in the 241-A-271 Building.

\section{Tank Farm Local Area Network (see Figure 1-4)}

TFLAN is the name of the project $\mathrm{W}-314 \mathrm{PLC} / \mathrm{MMI} /$ workstation network that will gather all specified tank farm data, display the data locally and at specified remote locations, interface with other projects and systems, and replace the MPS hardware. The system is made up of multiple PLCs located in existing structures at the $A$, $A N, A P, A W, A Y, A Z$, and SY Tank Farms; the 242-A evaporator; the 272-AW Building; the 244-A and 244-S DCRTs; and the project W-211 ICE Building at the SY Tank Farm. Signal inputs and outputs will be made directly to the PLC or through $1 / 0$ boxes distributed throughout a monitored local area. The 1/O boxes communicate to the PLC through digital transmission of data using twisted shielded pair wiring. Each PLC has an associated MMl used for local information query, display, and communication to the TMACS. The PLCs are connected into a TFLAN network that communicates using twisted shielded pair wiring or the phone line between the 200-East and 200-West Areas. Programming by an authorized system administrator determines the activities of each PLC/MMI pair with respect to data input, algorithms, alarms, displays, interlocks, control outputs, and communications.

\section{Master Pump Shutdown}

- General: The MPS is a subset function of the TFLAN system (see Figure 1-4). This TFLAN-networked TFLAN PLC system will replace the hardware of the existing MPS of the same name and function in the 200-East Area. 
An "approved program" at the source pump MMI/PLC can use any specified TFLAN connected device signal to control the pump. The approved program is an operating contractor (OC)-supplied item specifically written for each transfer type.

Signal inputs to the TFLAN are via the PLCs and are transmitted over the TFLAN communications link to the PLC controlling the waste transfer source pump.

An alarm condition of any MPS program specified input or by failure of the TFLAN communications link can cause the PLC controlling the source pump to activate an output. This output will control the pump MCC causing the pump and transfer to stop.

Immediate identification of the fault will be available through any TFLAN PLC and the TMACS. An interface will be established with the cross-site transfer (project $W-058$ ) at the 244-A DCRT. Project $W-058$ controls the MPS for the 200-West Area cross-site transfer pumps, and project W-314 controls the MPS for the 200-East Area pumps. Applicable data will be shared between the systems to allow controlled waste transfer between the areas.

- 242-A Building MPS: The five MPS relays in the 242-A evaporator relay cabinet number 1 will be replaced with outputs from the TFLAN PLC in 242-A for the pumps in the 242-A local area. Remote pumps will be controlled by outputs from the TFLAN PLC in that farm. The inputs to the MPS circuit have been covered by the individual descriptions for the $A P, A N, A W, A Y$, and $A Z$ Tank Farms.

- A and AX Tank Farm MPS: There are 25 inputs to the MPS circuit in pipelines, pits in the $A$ and $A X$ Tank Farms, and 
surrounding areas. These inputs will be wired to a TFLAN PLC in a 241-A-271 Building.

- 242-S Building MPS: The 200-West Area MPS has been replaced by the SY Tank Farm, the 244-S TFLAN PLCs, and the 242-S control room abandonment effort. All necessary signals to the 200-West Area MPS (except SST Farm inputs) will be available on the TFLAN PLC in the project W-211 ICE Building at the 241-SY Tank Farm.

- MPS Operation: The TFLAN system with the project W-314 connected signals provides the hardware and software infrastructure to allow MPS programming. Due to the large variety unspecified transfer routings available, the MPS programming for specific waste transfer routes will be done by the $O C$.

\section{Selected Signal Inputs}

In addition to the DST farms and associated facilities, selected signals will be input to the TMACS from the $A, B Y, C$, and $U$ Tank Farms; and the CR-271, 242-T, 244-AR, and 204-AR facilities. The signals are presently connected to a "Panalarm" annunciator panel that will be modified by the addition of a telephone modem interface to transmit the signals through the telephone modem and to the TMACS.

\section{TMACS Interface}

The TMACS data interface is a subset function of the TFLAN network. TFLAN communicates all inputs to the TMACS through a modem interface on the MMI (see Figure 1-4). The TMACS will perform the display, recording, and alarming functions required of the central monitoring station, and will communicate to the SACS. 
WHC-SD-W314-CDR-001, Rev. 0

\section{2-S Control Room}

Applicable signals alarmed and displayed in the 242-S control room will be relocated to the TFLAN PLC in the project W-211 ICE Building at the SY Tank Farm. Signals entering the control room from the northwest or southwest sides of the 242-S Building will be connected to terminal boxes at those respective locations for routing to the TFLAN PLC. Signals from the east of the 242-S Building (including the SY Tank Farm) will be routed directly to the TFLAN PLC. All signals will be available at the TFLAN PLC/MMI at the manned 278-WA facility over the TFLAN network.

\section{Piping}

\section{New Transfer Lines}

Three new transfer lines will be provided to support waste transfer operations. Each line will consist of a 3 -in. primary line encased within a 6-in. secondary line. The new transfer lines essentially will follow existing transfer routes and are located as follows:

- From valve pit 241-AN-B to sluice pit 241-AZ-02B isee Figure P-14).

- From sluice pit 241-AZ-O2B to valve pit 241-AX-A (see Figure P-15).

- From valve pit 241-A-A to valve pit 241-AW-A (see Figure P-16).

The new transfer lines will be sloped to prevent fluid accumulation and provide leak detection capability. Each transfer line will be provided with an encasement drain at its termination pit and a test riser to allow for future pressure testing of the secondary line. 


\section{Replacement of Existing Transfer Lines}

Along with new waste transfer lines, three transfer lines will be replaced:

- SN-216 (from the 244-A DCRT to valve pit 241-A-B)

- $\quad \mathrm{SN}-213 / 200$ (from valve pit $241-A-B$ to valve pit $241-A X-B$ )

- SL-502 (from valve pit 241-AX-B to the 241-AY-O2D)

NOTE: SL-502 consists of a 2 -in. primary line encased by a 4-in. secondary. $\mathrm{SN}-216$ and $\mathrm{SN}-213 / 200$ are 3-in. primary lines encased by 6 -in. secondary lines.

The replacement transfer lines will be designed as described for the new transfer lines and will parallel the existing transfer routes. The new lines will use the wall nozzle locations currently used by the existing lines to minimize any jumper modifications (see Figure $p-17$ ).

The wall nozzle connections will be upgraded to meet compliance criteria. The encasement stops on the outside of the pit wall and will be upgraded by extending the encasement to the inside wall of the pit.

\section{Valve Manifolds}

The valve manifold assembly upgrade for 200-East Area is the same as described for the AN Tank Farm and applies to valve pits 241-A-A, 241-A-B, 241-AX-A, and 241-AX-B (see Figure P-18 for a typical valve pit representation).

\section{Cover Blocks}

New cover blocks will be provided for pits 241-A-A, 241-A-B, 241-AX-A, and 241-AX-B receiving the new valve manifolds. The new cover blocks will accept the valve operating extension handles. The new jumper arrangements will be painted on the cover blocks to show the possible flow paths. 
WHC-SD-W314-CDR-001, Rev. 0

\section{DEMOLITION (810)}

All underground electrical systems and process piping will be replaced by project $W-314$ and will be placed in a safe configuration and abandoned in place unless otherwise noted.

\section{Instrumentation and Control}

- Leak Detection: The existing $A$ and $A X$ Tank Farm pit and encasement leak detectors will be removed. Similar to the AN Tank Farm description for 20 pit and pipeline leak detectors in the $A$ and $A X$ Tank Farms.

\section{Piping}

- As described for AN Tank Farm, debris expected to be found in the pits needing the special protective coating will require disposal.

- The existing jumpers located in the upgraded pits will be removed and disposed of accordingly.

- The existing cover blocks used for the upgraded pits will be removed and disposed of accordingly.

- Upgrading the pit wall nozzles will require minor modification of the pit wall to facilitate the extension of the piping encasement.

- The existing transfer lines will be abandoned in place except for the portion that must be removed for placement of the new transfer lines.

\section{242-A Gamewel!}

The 242-A Gamewell alarm system will be demolished. Necessary Gamewell alarm signals originating in the tank farms that have been connected to the PLC at each farm (as discussed in previous 
sections) and transmitted over the TFLAN network to the 242-A TFLAN PLC where they will be alarmed and displayed on that MMI.

\section{METHODS OF PERFORMANCE}

\section{A. PROJECT MANAGEMENT (WBS 1.1)}

The operating contractor $(\mathrm{OC})$ will provide overall project management and integration services as required to manage the project effectively. The work breakdown structure (WBS) includes overall systems engineering management and coordination, and project controls/business management functions (see Appendix A). The OC project management organization will prepare and maintain required project baseline documentation; interface with DOE, architect-engineer(s) (A-E), the onsite engineer/constructor contractor $(E / C)$, and other subcontractors and $O C$ personnel; provide coordination/integration with other TWRS activities and projects; manage project funds and schedule; provide regular performance and variance reporting; and utilize value engineering in support of definitive design and construction. Quality assurance support is included for the project design and construction activities.

\section{B. PERMITTING AND SAFETY (WBS 1.2)}

\section{Permitting}

The OC will prepare and obtain approval of environmental permits required for the project as identified in Appendix $I$.

\section{Safety Analysis}

The $\mathrm{OC}$ is responsible for coordinating development and approval of any safety analysis documentation required to support the project definitive design and construction efforts. As detailed in the project W-314 System Safety Program Plan, unreviewed safety question (USO) determinations 
and/or analyses, and revisions to existing tank farm safety basis documentation will be prepared, as required (ref 9).

\section{OTHER PROJECT COST ACTIVITIES (WBS 1.3)}

\section{Project Definition}

The $O C$ is responsible for providing the definition of project requirements, and preparing the project requirements baseline documentation.

\section{Program Integration and Support}

The OC will perform and coordinate system assessments (including field inspections), program planning, and management of program interfaces.

\section{Design and Construction Support}

The OC will provide technical and logistical support to, and review of, the project design media. Operations support for construction activities and site and facility-specific training services for offsite personnel will be included as needed.

\section{Conceptual Design}

- Engineering Report (Project W-314G): The onsite E/C was responsible for preparing the project $W-314 G$ engineering report and other applicable information to support the project W-314 FY97 validation process in August 1995. Technical and management support was provided by the $O C$.

- Design Configuration Baseline: The OC has overall responsibility for developing the projects $D C B L$ documentation with support from the onsite $E / C$ and other subcontractors. The DCBL package is being prepared using the Systems Engineering (SE) methodology defined in the project W-314 Systems Engineering Approach Review Document (WHC-SD-W314-SOW-003), Statement of Work (SE-SOW), and other DOE guidance. This effort will develop a 
requirements-based and fully integrated conceptual design for project W-314 to support the initiation of definitive design.

- Conceptual Design Report: This CDR was developed in support of the FY98 validation process by the onsite $E / C$, in conjunction with the $\mathrm{O} / \mathrm{C}$.

- Advanced Conceptual Design (ACD): Upon completion of the conceptual design, the $O C$ will identify any follow-up conceptual-level refinements and/or new tasks needed to further define the project systems engineering basis before Title I design, and perform detailed planning in support of ACD deliverables. Work packages are anticipated to be identified for $A C D$ work to be performed by the onsite $\mathrm{E} / \mathrm{C}$ as well as offsite subcontractor(s).

\section{Preliminary Safety Documentation}

The OC will be responsible for the preparation of initial USQ evaluations. This provides the process by which the project installations will be examined and compared against existing tank farm safety documentation to ensure that the existing documentation bounds any accident scenarios related to project upgrades or identifies the need for additional specific safety analyses through the safety assessment (SA) process.

\section{Permitting Plan}

The $\mathrm{OC}$ will prepare a plan to identify and provide the regulatory permitting requirements. The plan identifies the constraints the permits have on project activities, and provides a schedule and resources required to prepare and obtain approval of the permits.

\section{NEPA Documentation}

The OC will prepare all NEPA documentation associated with the project. An environmental assessment (EA) will address the impacts of the instrumentation, ventilation, and electrical upgrades included in this project. It is expected that the assessment will lead to a formal finding of 
no significant impact (FONSI) prior to initiating Title II definitive design. The waste transfer systems upgrades are addressed in the TWRS Environmental Impact Statement.

\section{A-E Selection and Procurement}

If necessary, and as determined by the forthcoming acquisition strategy as discussed in Section XV, the OC will be responsible for offsite A-E selection and procurement in support of the definitive design efforts. Administration of the offsite A-E contract(s) will also be performed by the OC.

\section{Quality Assurance Program Plan}

The OC TWRS Quality Assurance organization will be responsible for QAPP development based on the conceptual design and preliminary safety documentation.

\section{Site Characterization}

The $O C$ will provide soil sampling and characterization as needed during design and construction to identify any special requirements or conditions during construction and to classify waste for disposal.

\section{Startup Testing}

The OC provides the startup management and engineering support necessary to transcend the project installations from the construction phase to the operating phase through testing and calibration. This includes the preparation of necessary operating and maintenance procedures required for operation. An initial complement of spare parts will be provided.

\section{Operation Preparation}

The OC will perform activities necessary to prepare the project installations for operation by planning for and conducting an OC Readiness Review and Self Assessment. This review and assessment provides verification that all required design, construction, inspection, testing, and documentation 
are complete and that the systems are fully operable. Support to the independent operational readiness review (ORR) will also be provided.

\section{DEFINITIVE DESIGN}

For this CDR, the following methods of performance were assumed for project definitive design. The methods are consistent with other ongoing and proposed tank farm upgrade projects. The methods will be revisited upon development of a project acquisition plan, contained within the Project Plan, and will be submitted during the KD-1 process.

\section{Title I (WBS 1.4)}

The onsite $E / C$ will develop the preliminary design (Title I) documentation in accordance with the completed CDR effort. This effort will culminate in the issuance of a Title 1 report containing drawings, outline specifications, and narrative descriptions of the planned upgrades.

Title II (WBS 1.5.A.1)*

The onsite E/C will also provide detailed design (Title II) services for the project in accordance with the approved Title / baselines. Design packages will be developed during Title II to allow for construction on a farm-by-farm basis. Definitive design drawings and specifications, and other supporting engineering documentation, will be developed during Title II.

Title III (WBS 1.5.A.2)

The onsite $E / C$ will perform the engineering during construction, prepare project as-built drawings, and support project documentation turnover. In process construction, inspection will be performed by construction contractor personnel with final acceptance inspections the responsibility of the onsite $E / C$.

\section{E. PROCUREMENT (WBS 1.5.A.3)}

The OC will procure long-lead engineered equipment.

"Typical WBS sub-elements for 1.5.B, C, D, E, F and 1.6.A, B, C, D) 
WHC-SD-W314-CDR-001, Rev. 0

F. CONSTRUCTION (WBS 1.5.A.4)

Onsite E/C Contractor

The onsite $E / C$ will perform construction services for radiologically contaminated work inside/outside the tank farm; utility tie-ins; and demolition/removal of structures, systems, and components that are taken out of service as a result of the project upgrades.

\section{Offsite Construction Contractor}

Fixed-price construction contracts will be utilized whenever possible for the construction work based on contamination levels and the interfaces with new and existing systems.

\section{Operating Contractor}

The OC will provide for the burial of contaminated soil, equipment, and debris removed during construction.

\section{G. HPT SUPPORT (WBS 1.5.A.5)}

The OC will provide health physics technicians (HPTs) to support construction and other field work as needed, as well as personnel protective equipment and monitoring devices.

\section{ACQUISITION PLANNING}

\section{Mission Need}

In accordance with DOE Order 4700.1, "Project Management System," the mission need for project W-314 was documented in a formal Justification of Mission Need (JMN) that was submitted to DOE in support of the request for KD-O. KD-O was approved by DOE in February 1995.

\section{Systems Engineering Management}

There is a recognized need for the tank farm facilities, as well as all other TWRS elements, to be managed and operated as one fully integrated system. The DOE has placed a strong emphasis on ensuring that all TWRS work be fully supported by sound technical information and adequately defined functions and 
requirements. To support this objective, DOE has directed all new TWRS projects, as well as certain ongoing projects and activities, to utilize an integrated SE approach for planning and execution of work scope. Based on this DOE direction, a dedicated effort has been, and continues to be, made during the conceptual design phase to establish the project $W-314$ objectives and design requirements based upon continued lower-level SE development of the TWRS program functions and requirements $(F \& R)$ and other applicable work.

\section{Research and Development Requirements}

Project W-314 will provide upgrades and renovations to existing process support systems. There is no known research and development work required to support the project.

\section{Conceptual Design Approach}

An integrated onsite team developed the project W-314 conceptual design using the prescribed SE methodology. The SE approach and planning were presented to $\mathrm{RL}$ and were approved in May 1995. The SE approach utilized during the conceptual design phase will result in a detailed DCBL that contains the necessary conceptual-level design specifications, project interface documentation, and supporting decision criteria and analyses (all traceable back to the higher-level TWRS functions and requirements) to support the start of Title I engineering. Since the initial planning in May 1995, it became apparent that a CDR consistent with DOE Order 4700.1 requirements was required prior to the DCBL becoming available to support the FY98 budget validation process. This CDR utilizes the preliminary DCBL products that were available when the CDR was initiated to develop a feasible conceptual approach and design to functional requirements and provides reliable cost and schedule baselines by which to validate an FY98 budget request.

To support the DCBL development, the $O C$ is utilizing several existing contracts to obtain technical and other support services to meet the needs of the project. This includes the use of an existing basic ordering agreement (BOA) contract with the strong team comprised of Los Alamos Technical Associates (LATA), British Nuclear Fuels, Ltd. (BNFL) and TRW Systems Integration Group team 
members. Also, the onsite E/C contractor, ICF Kaiser Hanford Company (ICF KH), and other BOA subcontractors available through ICF $\mathrm{KH}$ are being utilized in support of the conceptual design effort.

\section{Cost, Schedule, and Performance Management}

Management practices will be employed in accordance with DOE Order 4700.1 and applicable procedures to review, monitor, and evaluate total project costs (TPC), schedule, and performance throughout the project acquisition process and to provide assessments for consideration at key decision points or when significant baseline variances occur.

Reporting on the accomplishment and status of the acquisition process will be provided as required. Of particular importance will be the reporting of any potential cost, schedule, or performance threshold breaches before corrective actions are foreciosed.

\section{Acquisition Strategy}

The acquisition strategy for project $W-314$ will reflect the management concepts that will be used to direct and control the project to ensure that the systems being acquired satisfy the approved mission need. The project W-314 Acquisition Strategy, including a description of the contractual basis for the project, will be in the Project Plan as a KD-1 submittal.

\section{REQUIREMENTS AND ASSESSMENTS}

\section{A. SAFEGUARDS AND SECURITY}

Proposed upgrades will be constructed within the 200-East/West Area security fence boundaries. 


\section{B. HEALTH AND SAFETY}

\section{Radiation Protection}

Adequate shielding is provided by cover blocks, shielding walls, and/or earthcover and reduces exposure to as low as reasonably achievable (ALARA) for personnel safety.

Tank risers and pits are shielded by earth, concrete plugs, cover blocks, or a combination thereof.

\section{Industrial Safety}

The design of project W-314 will comply with Occupational Safety and Health Administration (OSHA) regulations, DOE health and safety standards regulations, the Tank Farm Health and Safety Plan, and WHC controlled manuals.

\section{Risk Prevention During Construction}

During construction, contractors will be required to take all reasonable precautions in their work to protect the health and safety of their employees, subcontractors, the operating contractor, and DOE personnel.

A 24-hr advance notice of any excavation work disrupting roadways or other services will be required to ensure that emergency personnel (i.e., patrol and fire department) receive adequate notification.

DOE health and safety standards and regulations will be followed to minimize risks during construction. Removing, packing, and disposing of any contaminated (radiological, hazardous, or both) soil radioactive or dangerous waste (or both) and materials found during excavation will comply with appropriate safety standards and procedures. At all times, the construction contractor will ensure that the construction area is accessible to emergency vehicles or personnel and that emergency evacuation routes are not obstructed. 


\section{DECONTAMINATION AND DECOMMISSIONING}

Project $\mathrm{W}-314$ will be designed to minimize contamination and release of hazardous materials. Process system components can be isolated, packaged, and removed for further decontamination or disposal. Confinement systems that come into contact with waste, or have the potential to become contaminated, will be constructed to minimize absorption of waste and facilitate decontamination.

During definitive design, consideration will be given to the decontamination and disposal of each component installed in the facility.

\section{MAINTENANCE REQUIREMENTS}

Project $W-314$ will be designed to allow access for maintenance work. The use of a bag-in/bag-out method during HEPA filter changes will minimize the spread of contamination and personnel exposure.

The location of instrumentation and electrical equipment will allow crane access to the process pits. Space is provided adjacent to the process pits so that cover blocks can be stacked without moving the crane.

Equipment, instrumentation, detectors, and systems located in the process pits will be capable of being removed and replaced remotely. Rotating equipment not readily accessible will be lubricated remotely.

\section{E. QUALITY ASSURANCE}

\section{Quality Assurance Activities .}

Quality assurance activities for all contractors involved in the design, procurement, construction, inspection, and testing of the proposed project will be formulated and executed in accordance with the project-specific Quality Assurance Program Plan (OAPP). Minimum quality attributes are included in the project functions and requirements document which is the PDRD for project $W-314$, and will be incorporated in the project-specific QAPP. Based upon a graded approach, the QAPP will implement 
applicable quality assurance requirements identified in Code of Regulations (CFR) 10 CFR 830.120, "Quality Assurance Requirements for Nuclear Facilities." The QAPP will provide a format for establishing the scope of the quality-related activities and the specific quality assurance requirements and responsibilities based upon assigned safety classifications. The OAPP will indicate the project critical characteristics, corresponding safety classification assignments, and programmatic controlling documents. The specific technical and quality programmatic requirements, material certifications, qualification and certification of personnel, inspections, examinations and testing, and applicable quality assurance records will be established during definitive design and included in design documents. Specifications will require controls to exclude misrepresented products.

\section{Safety Classification}

Safety classifications have been documented for the existing tank farm structures, systems and components. For this report, the existing safety classifications have been used as a planning and estimating basis for the project $W-314$ work. The validity of this approach has been confirmed by the initial USO screening process. During the project W-314 conceptual and definitive design development efforts, the safety classifications for all affected tank farm structures, systems, and components will continue to be reviewed and revised, if needed, to ensure that appropriate safety-related considerations are placed on design, procurement, construction, testing, operation, maintenance, and future modifications.

Safety classification criteria and methodology are defined in WHC Management and Requirements and Procedures Manual WHC-CM-1-3, MRP 5.46. Safety classifications are determined through analysis and consequences of failure, and the safety class designations form the basis for the design and quality assurance requirements applied to the project. Safety Class 2 is the highest level anticipated for any project W-314 elements. 
NOTE: The safety class classification has changed recently due to revisions to WHC-CM-4-46. For this CDR, Safety Class 2 and 3 should be considered equivalent to "safety significant" under the new standard.

The safety documentation specific to this CDR effort is in the SSPP and includes interim safety equipment lists for DSTs (WHC-SD-WM-SEL-026, Rev. 1), for SSTS (WHC-SD-WM-SEL-027, Rev. 1), and for aging waste tanks (WHC-SD-WM-SEL-020, Rev. 2). The safety classifications are considered to be conservative in their assignments and were used as general guidance. Exceptions to the ISEL safety classifications are noted in the associated USO screening forms.

\section{F. ENVIRONMENTAL COMPLIANCE}

Proposed designs will comply with federal and state regulations applicable to waste management units for storage and treatment of hazardous wastes. Existing enclosures for access, vents and instrumentation will not be upgraded except as noted in this CDR.

Exhaust air filtering systems will be provided for the contaminated air streams to control particulate matter. Design and selection of air treatment trains and the stack will be based on Best Available Radionuclide Control Technology (BARCT) to minimize the release of radionuclides in accordance with WAC 246-247.

Fugitive dust generated during construction or related activities shall be minimized in accordance with WAC 173-400.

\section{G. ENVIRONMENTAL DOCUMENTATION AND PERMITS}

\section{National Environmental Policy Act (NEPA)}

NEPA documentation will be prepared for this project pursuant to the National Environmental Policy Act (NEPA) of 1969 and as implemented by DOE in $10 \mathrm{CFR}$ 1021. The environmental impacts reasonably expected 
from the tank farm instrumentation and controls, ventilation, and electrical upgrades will be evaluated in an environmental assessment (EA). Project W-314 transfer system upgrades are addressed in the TWRS environmental impact statement.

\section{State Environmental Policy Act (SEPA)}

A SEPA review is required for project $W-314$, and a SEPA checklist will be prepared and submitted to the Washington State Department of Ecology with permit applications. However, based on past history with the Washington State Department of Ecology, it is anticipated that the DOE NEPA documentation will satisfy the SEPA documentation requirements.

\section{Permitting}

As a part of the conceptual design activities for project W-314, all permits required to initiate/complete construction and start of operations have been identified. This information has been developed into a permitting plan indicating the constraints that permits may have on project activities and identifies responsibility for obtaining the necessary permits. The plan addresses recommended methods for obtaining the necessary regulatory permits needed to support the project design, construction, and startup phases (see Appendix I).

\section{H. DESIGN COMPLIANCE}

The design and construction of project W-314 will comply with the criteria listed in the PDRD (ref 8 ).

\section{IDENTIFICATION AND ANALYSIS OF UNCERTAINTIES/DESIGN ASSUMPTIONS}

\section{A. GENERAL}

The interim tank farm safety basis was used as the design planning and estimating basis for safety classifications for project W-314 installations. The classifications were developed to comply with the criteria in 
WHC-SD-W314-CDR-001, Rev. 0

WHC CM-1-3, MRP 5.46. The manual was replaced on February 26, 1996 via issuance of Rev. 2 of WHC-M-4-46, "Safety Analysis Manual," concurrent with finalization of this CDR effort. A formal analysis of the change in the definitions of safety classification designations has not been made; therefore, it is assumed that this change from Safety Class 1, 2 and 3 , to designation of safety class by safety significant structures, systems, and components will not impact the cost or schedule baseline within this CDR. It is not envisioned that the new classifications will require safety features beyond those currently in place for either design or operation of the existing tank farm facilities. A change in safety class definition alone could require additional safety related design and operating features, such as redundancies in power supply or instrumentation, which could impact the project cost baseline. The existing TWRS facilities have not been reclassified and, therefore, it is not possible at this time to quantify this uncertainty to the project.

- A recent \$3 million reduction in FY96 expense funding will result in a departure from the original SE approach as defined in the SE-SOW (ref 4). The budget reduction will significantly curtail the SE activities planned to be performed in FY96. A more graded approach for the application of SE to project W-314 will be applied. Lower level functions, requirements, and architectures will be developed in FY97 during the advanced conceptual and/or early definitive design phase of the project. This change in approach was incorporated into the budget and design planning of the CDR.

- The conceptual project schedule reflects the receipt of KD2 on April 1, 1998. DOE Milestone T2C-97-512 requires receipt of KD2 for project W-314 on December 31, 1997. Based on a review of the detailed planning in the schedule, a change to this milestone is warranted. The change request is being developed and will be submitted to RL upon approval of the CDR. 
- All equipment (instrumentation, electrical, and mechanical) will be designed to operate in the environment intended for its use.

\section{B. PITS AND PIPING}

- The special protective coating is expected to provide the lining that provides containment required by regulatory agencies. This assumption is consistent with other ongoing tank farm pit modification efforts. Discussions related to this approach will be conducted with WDOE in the very near future. Coating existing pits appears to be a cost effective way of achieving performance requirements for these ancillary facilities as well as supporting operations ALARA objectives.

- The preparation of the pit surfaces for coating application is uncertain at this time (i.e., sandblasting, water blasting, and dry-ice). The method will be determined during the design phase. Any method will require mask work within a greenhouse in a radiologically-contaminated environment. Therefore, the exact method to be utilized is not expected to be a significant cost driver in comparison to the costs for set-up, special work permit (SWP) work, and disposal of contaminated materials.

- During coating operation, the transfer/process lines will be removed from operation.

- The transfer line routes are appropriate and available for the installation. These routes can be constructed with minimum slopes as required and will not have major obstructions or interferences. New transfer lines are selected based on the current waste volume projections for waste transfer schedule and tank designations for planned retrieval activities including in-tank sludge washing. The proposed locations of the future low-level least of the AP Tank Farm) and high-level (southwest of the 244-A DCRT) vitrification facilities were considered in approximating the locations of the new 
transfer lines. Since many of the new pipeline installations parallel existing routes, it is foreseen that routing and minimum slope requirements can be achieved.

- The valve manifold design is based on one valve pit and one sluice pit. Until further investigation is performed during design, the level of modification that may be required in specific pits is uncertain. However, the total cost to do all pits should be adequate since the valve and sluice pits generally are representative of all the pits.

- The design of the valve manifolds will provide transfers from any DST to any other DST. The valve manifolds will allow simultaneous transfers; however, some limitations, but not beyond those that currently exist, will apply when performing multiple transfers through the same pit.

- Project W-314 upgrades will utilize existing flushing capabilities of the transfer system and no additional flushing capabilities will be needed. If additional flushing capabilities are required, some cost increase will be incurred.

- The plan to use a plug and receptacle system for the valve positioning signal may not be optimum. During design, other less costly methods for providing position indication such as locating them outside the pit environment, will be investigated.

\section{c. ELECTRICAL}

- The existing $13.8 \mathrm{kV}$ utility feeders have adequate capacity to supply power for SST tank farms' limited "operations" during controlled, clean, and stable conditions. 


\section{INSTRUMENTATION}

- TMACS is capable of handling the additional input points proposed by project W-314. A separate Information Management System (IMS) will not be needed. Any IMS functions required can be accommodated by the existing TMACS and SACS.

- The existing signals to be input to the TMACS from the A, BY, C, and $U$ Tank Farms, and the CR-271, 242-T, 244-AR, and 204-AR facilities are presently connected to an existing "Panalarm" annunciator according to discussions with tank farm engineering. Design verification of this configuration has not been performed. If the signals aren't connected, additional funds would be required to relay them to TMACS.

- Systems provided by on-going project W-058 will control and shut down the 200-West to 200-East Area waste transfer pumps. Project $W-058$ design is complete and the project is in the construction phase.

- The 242-S control room annunciators and readouts will be abandoned in place.

- The WHC-developed/supplied "GEMS" stack monitor specification will be used. The GEMS system includes the capability to transmit exhaust air flow volume and temperature, sampled air volume, measured radiation, and radiation equipment fail alarms.

- Project W-211 provides adequate temperature measurement capabilities to support tank retrieval operations. Project W-314 will not be required to replace the temperature measurement devices installed by project $\mathrm{W}-211$.

- Displacement gages for the primary tank liquid level have been installed at DSTs discussed in this report. 
- The central pump pit in each tank should have space for installation of the waste transfer flow meters. If space is not available, an alternate location for the meter would be required at an additional cost to the project.

- The leak detection pit will be dry. The density measurement requirement for liquids discovered in these pits will be met by sampling and analysis. The leak detection pit pump riser can be used for installation of a sample pump for obtaining liquid samples for specific gravity determination by laboratory analysis.

- The existing transfer lines in 200-East Area do not have continuous leak detection. The pipelines that project $W-314$ will install in 200-East Area are not significantly longer than the existing lines which use low-point leak detection systems, therefore, the project assumes that continuous pipeline leak detection will not be required. However, if it is required, the cost for pipeline installations would increase.

- The leak detector design using a single conductivity element placed up to 1 inch from the surface to be monitored le.g., pit floor, annulus floor, leak detection pit floor, or encasement bottom) is adequate for determining a leak within 24 hours.

- Where necessary, drains that require plugs or other suitable methods for water holdup to allow the leak detectors to operate are assumed to be installed and operable. If the existing plugs are not in place, they will be installed by operations or by the project at a minimal additional cost. 


\section{E. VENTILATION}

- Tank vapor space characterization of toxic air pollutants and flammable vapors is not well defined. The need for special treatment devices, such as carbon adsorbers, is uncertain. Therefore, project $W-314$ will provide the capability for future installation of treatment devices.

- The proposed location of the new ventilation equipment is adjacent to the existing equipment to minimize overall installation costs. If interferences are identified during Title I design, the location and/or orientation may need to be modified. This may moderately lengthen the run of new ductwork between the existing duct and the new ventilation equipment at an additional project cost.

- The tank farms currently have no identified ammonia release hazard. Temporary ammonia monitoring equipment will be utilized during future mixer pump operation during retrieval to determine if the pumps cause significant ammonia release. Ammonia control equipment is not part of the project W-314 scope, but the design has the capability of adding it at a later date.

- Ventilation airflow rates will be adequate for waste cooling during storage and transfer and, therefore, condensers and chillers are not required as part of project $W-314$.

- Very low flows (below existing capacity) in primary ventilation systems are acceptable as long as required tank negative pressures and flows determined necessary for flammable gas control and/or tank cooling are maintained.

- The existing scaffolding and other support equipment used at the existing primary exhaust stacks can be relocated and reused at the new stacks. 
- It is assumed that airflows from individual tanks can be adjusted to achieve the desired operations via existing valves and/or future engineered inlets.

\section{REFERENCES}

1. U.S. Department of Energy Order 4700.1, "Project Management System."

2. Upgrade Scope Summary Report (USSR), "Tank Farm Restoration and Safety Operations (TFRSO)," Project W-314, prepared by Westinghouse Hanford Company, Document No. WHC-SD-W314-RPT-003, Rev. 0 , February 1996.

3. Engineering Report, "241-AW Tank Farm Upgrades," Project W-314G, prepared by ICF Kaiser Hanford Company, Document No. WHC-SD-W314-ER-002, Rev. 0, August 1995.

4. Supporting Document, "Systems Engineering SOW Approach Review for Project W-314, Tank Farm Restoration and Safe Operations," Project W-314, prepared by Westinghouse Hanford Company, Document No. WHC-SD-W314-SOW-003, Rev. 0, June 1995.

5. Engineering Study, "Project W-314 DST and DCRT Instrument and Control Systems, Initial Assessment," Project W-314, prepared by Westinghouse Hanford Company, Document No. WHC-SD-W314-ES-018, Rev. 0 , January 1996.

6. Engineering Study, "DST and DCRT Tank Farm Electrical Distribution Systems Initial Assessment," Project W-314, prepared by Westinghouse Hanford Company, Document No. WHC-SD-W314-ES-020, Rev. O, January 1996. 
7. Engineering Study, "Initial Assessment Report for Mechanical Systems Upgrade," Project W-314, prepared by Westinghouse Hanford Company, Document No. WHC-SD-W314-ES-021, Rev. O, February 1996.

8. Preliminary Design Requirements Document, "Tank Farm Restoration and Safe Operations," Project W-314, Document No. WHC-SD-W314-DRD-001, Rev. 2, March 1996 (draft).

9. Supporting Document, "System Safety Program Plan for Project W-314, Tank Farm Restoration and Safe Operations," Project W-314, prepared by Westinghouse Hanford Company, Document No. WHC-SD-W314-PAP-001, Rev. O, February 1996.

10. Letter of Instruction Number 1 for Conceptual Design Report Planning, Project W-314, Document No. 8K530-95-SRB-007, October 24, 1995.

11. Letter of Instruction Number 2 for Conceptual Design Report, Project W-314, Document No. 8K530-95-SRB-008, November 9, 1995.

12. Letter of Instruction Number 3 for Conceptual Design Report, Project W-314, Document No. 8K530-96-SRB-001, January 15, 1996.

13. Department of Energy Letter for Project 96L-EWW-314, "Waiver of the Metrication Transition Plan for Hanford," Document No. 94-PRJ-033, April 20, 1994.

14. Document Transmittal, "Engineering Work Plan for Conceptual Design Report," Project W-314, Document No. TR-W-314-108, January 15, 1996.

15. Report, "Criteria for the Modification of the Master Pump Shutdown System," Document No. WHC-SD-WM-TI-142, Rev. 0, July 19, 1984. 
WHC-SD-W314-CDR-001, Rev. 0

16. Report, "Gaseous Effluent Monitoring System Design Criteria," Document No. WHC-SE-WM-CR-058, March 28, 1995.

17. Report, "Tank Farm Potential Ignition Sources," Document No. WHC-SD-WM-ES-362, Rev. 1, January 30, 1996. 
WHC-SD-W314-CDR-001, Rev. 0

\section{APPENDIX A}

\section{Work Breakdown Structure}




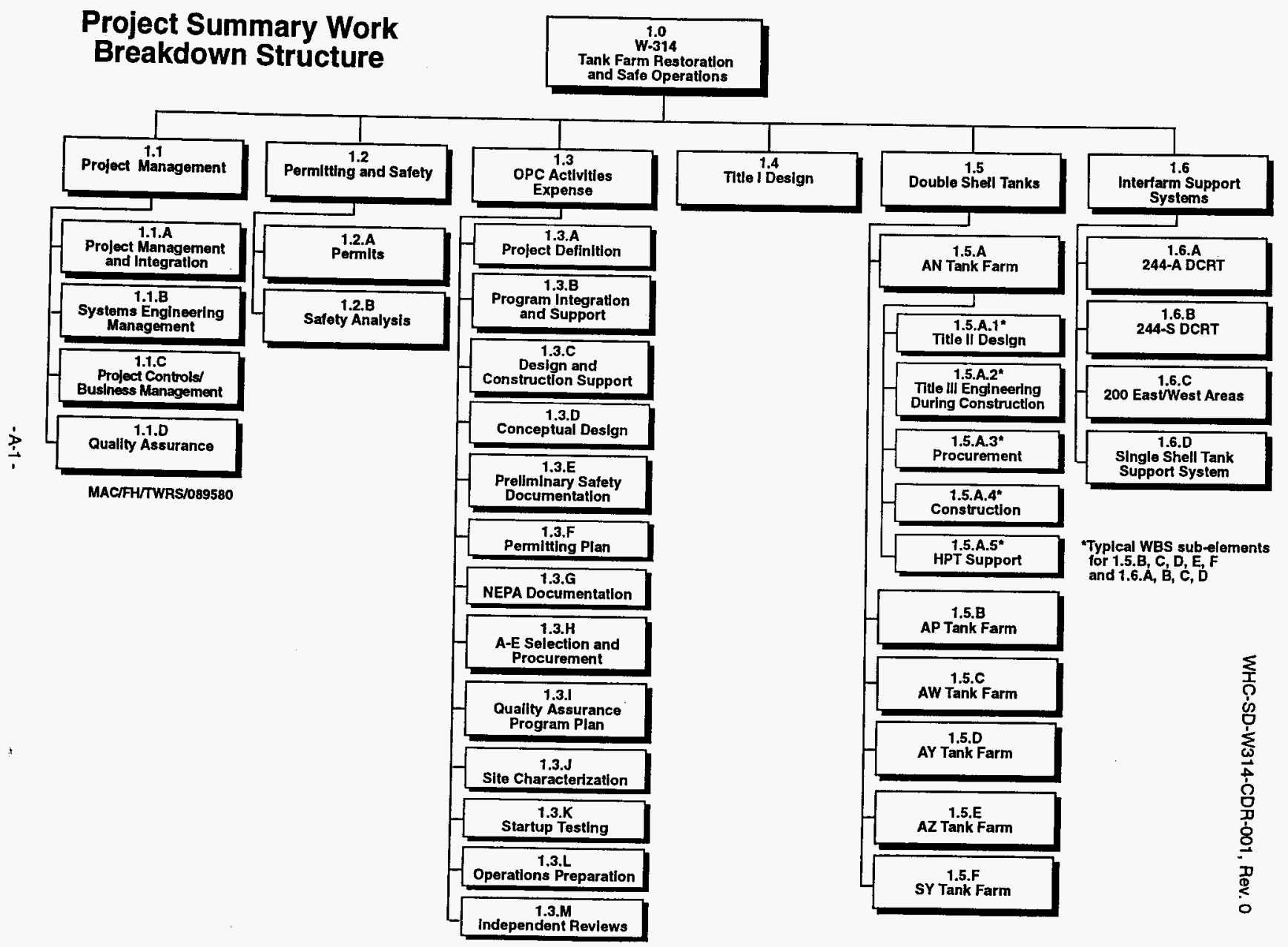




\section{APPENDIX B}

Budget Authorized/Budget Outlay Schedule 
PROJECT W-314

TANK FARM UPGRADES

BABO SCHEDULE (CAPITAL DOLLARS)

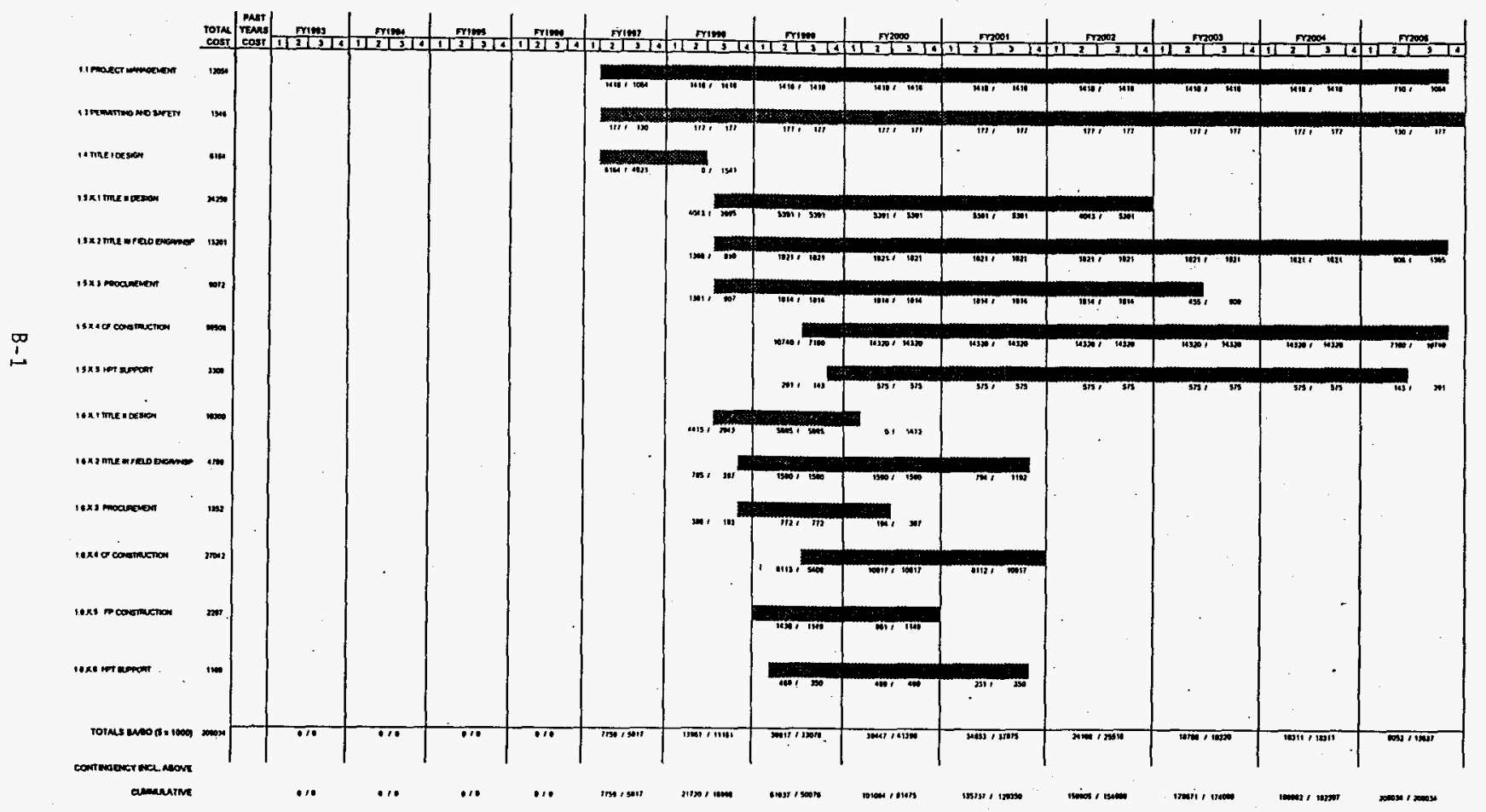

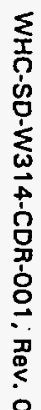


PROJECT W-314

TANK FARM UPGRADES

BABO SCHEDULE (EXPENSE DOLLARS)

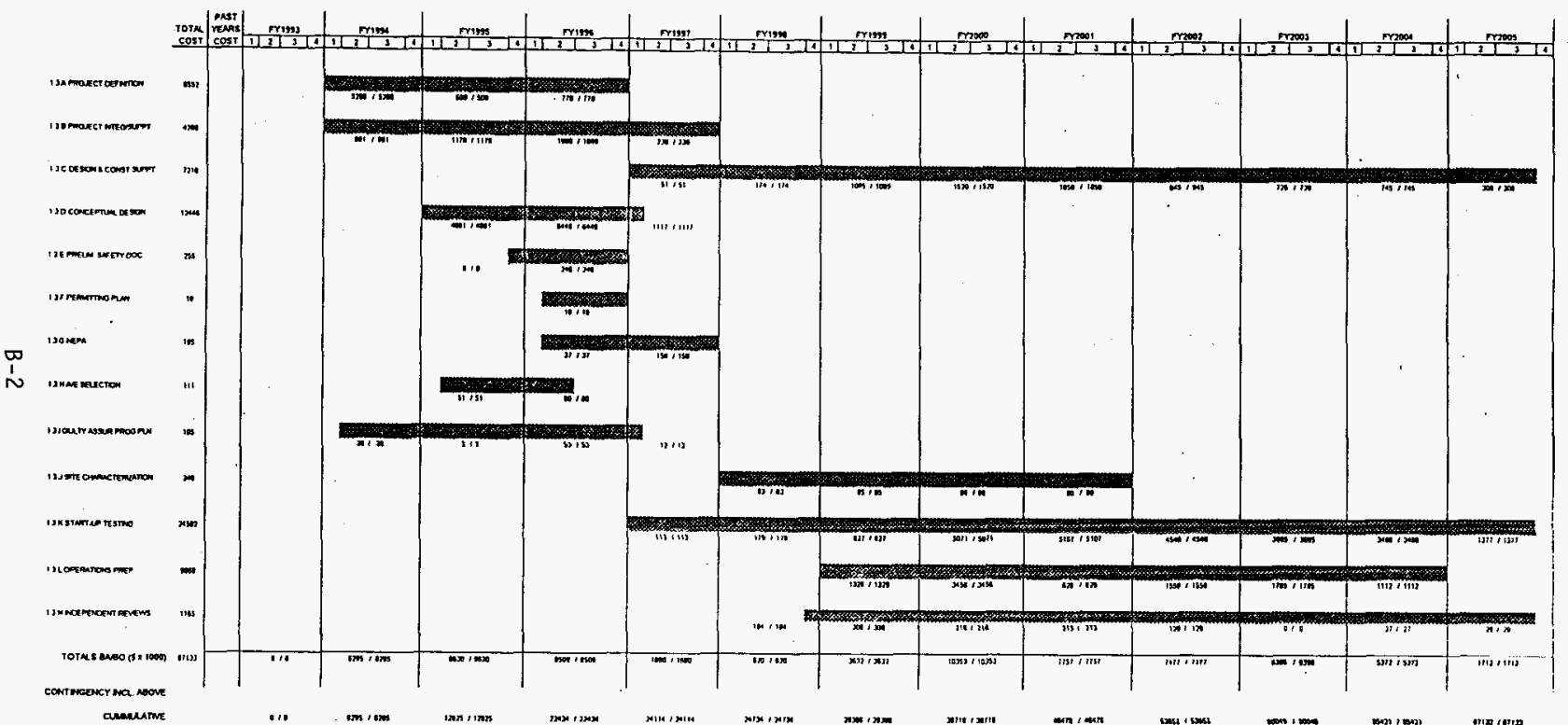


WHC-SD-W314-CDR-001, Rev. 0

\section{APPENDIX C}

Cost Estimate Summary 
KAISER ENGIHEERS HANFORD WESTIMGHOUSE MANFORD COMPANY JOB NO. H314BAC2
* IEST - INTERACTIVE ESTIMATIHG * *

TANK FARM RESTORATION AHD SAFE OPERATIONS

H
DOE RO1
D PROJECT COST SUMMARY REV.
PAGE 1 OF 84

BY TLH RDP OKH JJM

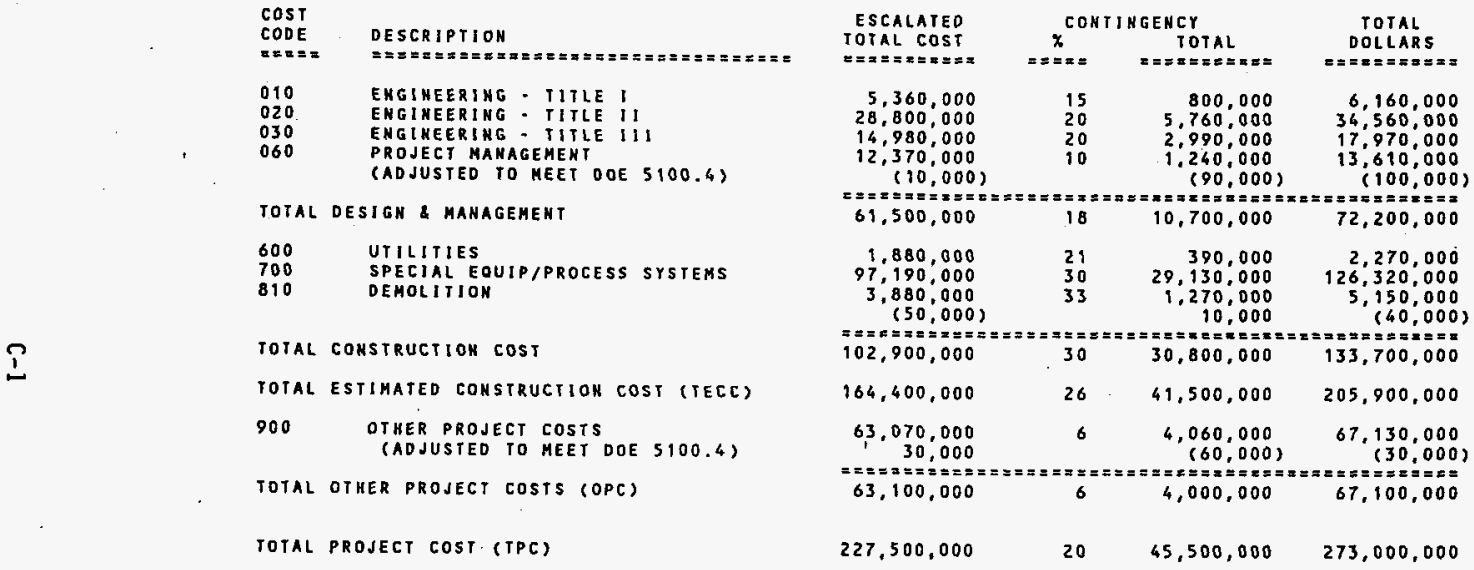

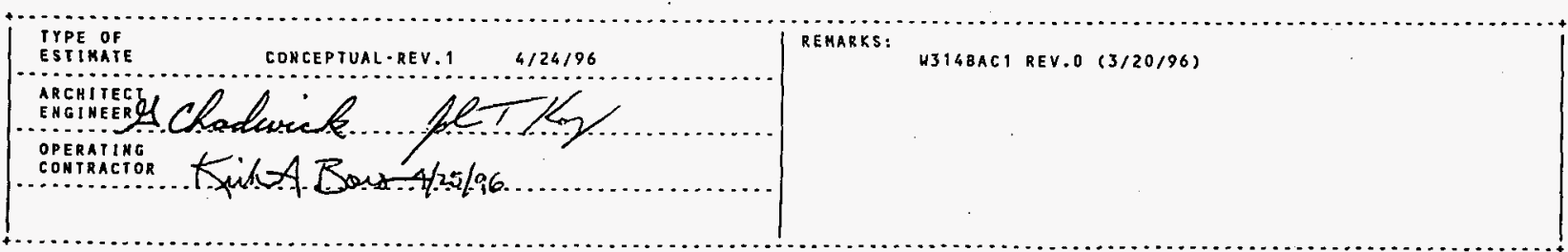

(ROUNDED/ADJUSTEO TO THE HEAREST" $10,000,100,000 "$ "PERCENTAGES hot ReCalculateo to ReFleCt ROUNDING 
KAISER ENGINEERS. HAKFORD WESTINGHOUSE HAHFORD COMPANY

JOB NO. N3 14 BAC2
* * IEST * INTERACTIVE ESTIMATING **

TANK FARM RESTORATION AHD SAFE OPERATIONS H - $3: 4$ CONCEPTUAL ESTIMATE REV. DOE ROZ - HORK BREAKDOWN STRUCTURE SUMMARY
PAGE 2 DF 84

PATE OL/23/96 14:56:21

BY TLHRDP DKH JJH

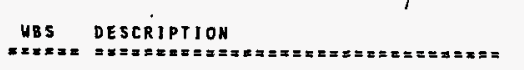

1 AOI PH E INTEGRATION IITLE - I

TAOZ PH IHTEGRATION TITLE.

IAOS PN INTEGRATION - CONST.

SUBTOTAL IA PROJECT MGKT. \& INTEGRATION

1801 SYSTEKS ENG. MGKT. - TITLE I

1802 SYSTEMS ENG. HGHT. - TITLE I

1803 SYSTEMS ENG. HGHT. - CONST

SUBTOTAL $1 B$ SYSTEMS ENG. MGMT.

ICO1 PCIBUSIHESS MGNT - TITLE 1

ICO2 PC/BUSIHESS MGMT: TITLE II
ICOS PC/BUSIHESS MGMT. CONSI

SUBTOTAL IC PROJ CNTRLS/BUSINESS MGMT

\begin{tabular}{|c|c|c|c|c|c|c|c|c|}
\hline $\begin{array}{l}\text { ESTIMAIE } \\
\text { SUBIOTAL } \\
=======\end{array}$ & $\begin{array}{l}\text { OHSITE } \\
\text { INDIRECTS } \\
========x\end{array}$ & $\begin{array}{c}\text { SUB } \\
\text { IOTAL } \\
==x=x====\end{array}$ & $===\approx=\pi$ & $\begin{array}{l}\text { L ATION } \\
\text { TOTAL. } \\
===\approx x==x\end{array}$ & $\begin{array}{c}\text { SUB } \\
\text { TOTAL } \\
x==x=x x==\end{array}$ & $\begin{array}{l}\text { CONTJ } \\
= \pm x \\
= \pm=\end{array}$ & $\begin{array}{l}\text { I KGENCY } \\
\text { TOTAL } \\
==x==\pi= \pm=\end{array}$ & $\begin{array}{c}\text { TOTAL } \\
\text { DOLLARS } \\
=\approx==\approx=2= \pm\end{array}$ \\
\hline $\begin{array}{r}427746 \\
2239150 \\
2320133\end{array}$ & $\begin{array}{l}0 \\
0 \\
0\end{array}$ & $\begin{array}{r}427746 \\
2239150 \\
2320133\end{array}$ & $\begin{array}{r}2.89 \\
10.43 \\
17.15\end{array}$ & $\begin{array}{r}12375 \\
233582 \\
397838\end{array}$ & $\begin{array}{r}440121 \\
2472732 \\
2717971\end{array}$ & $\begin{array}{l}10 \\
10 \\
10\end{array}$ & $\begin{array}{r}44012 \\
247273 \\
271797\end{array}$ & $\begin{array}{r}686933 \\
2720006 \\
2989769\end{array}$ \\
\hline 4987029 & 0 & 4987029 & 12.91 & 643785 & 5630824 & 10 & 563082 & 6193908 \\
\hline $\begin{array}{l}471240 \\
793968 \\
573750\end{array}$ & $\begin{array}{l}0 \\
0 \\
0\end{array}$ & $\begin{array}{l}471240 \\
793968 \\
573750\end{array}$ & $\begin{array}{r}2.67 \\
10.37 \\
21.54\end{array}$ & $\begin{array}{r}12563 \\
82369 \\
123560\end{array}$ & $\begin{array}{l}483803 \\
876337 \\
697310\end{array}$ & $\begin{array}{l}10 \\
10 \\
10\end{array}$ & $\begin{array}{l}48380 \\
87633 \\
69731\end{array}$ & $\begin{array}{l}532183 \\
963971 \\
767062\end{array}$ \\
\hline 1838958 & 0 & 1838958 & 11.88 & 218492 & 2057450 & 10 & 205744 & 2263196 \\
\hline $\begin{array}{l}248799 \\
846564 \\
585178\end{array}$ & $\begin{array}{l}0 \\
0 \\
0\end{array}$ & $\begin{array}{l}248799 \\
846564 \\
585178\end{array}$ & $\begin{array}{r}2.67 \\
10.43 \\
21.54\end{array}$ & $\begin{array}{r}6633 \\
83288 \\
126069\end{array}$ & $\begin{array}{l}255432 \\
934852 \\
711247\end{array}$ & $\begin{array}{l}10 \\
10 \\
10\end{array}$ & $\begin{array}{l}25543 \\
93485 \\
71125\end{array}$ & $\begin{array}{r}280975 \\
1028338 \\
782372\end{array}$ \\
\hline 1680541 & 0 & 1680541 & 13.15 & 220990 & 1901531 & 10 & 190153 & 2091685 \\
\hline $\begin{array}{l}220742 \\
551855 \\
441484\end{array}$ & $\begin{array}{l}0 \\
0 \\
0\end{array}$ & $\begin{array}{l}220742 \\
551855 \\
441484\end{array}$ & $\begin{array}{r}2.94 \\
10.10 \\
20.82\end{array}$ & $\begin{array}{r}6490 \\
55726 \\
91928\end{array}$ & $\begin{array}{l}227232 \\
607581 \\
533412\end{array}$ & $\begin{array}{l}10 \\
10 \\
10\end{array}$ & $\begin{array}{l}22723 \\
60758 \\
53341\end{array}$ & $\begin{array}{l}249955 \\
668339 \\
586753\end{array}$ \\
\hline 1214081 & 0 & 1214081 & 12.70 & 154144 & 1368225 & 10 & 136822 & 1505047 \\
\hline 9720609 & 0 & 9720609 & 12.73 & 1237421 & 10958030 & 10 & 1095801 & 12053836 \\
\hline $\begin{array}{r}81043 \\
60534 \\
3077 \\
1151886\end{array}$ & $\begin{array}{l}0 \\
0 \\
0 \\
0\end{array}$ & $\begin{array}{r}81043 \\
60534 \\
3077 \\
1951886\end{array}$ & $\begin{array}{r}4.31 \\
13.09 \\
4.32 \\
8.96\end{array}$ & $\begin{array}{r}3493 \\
7926 \\
133 \\
103167\end{array}$ & $\begin{array}{r}84536 \\
68460 \\
3210 \\
1255053\end{array}$ & $\begin{array}{l}10 \\
10 \\
10 \\
10\end{array}$ & $\begin{array}{r}8454 \\
6846 \\
321 \\
125506\end{array}$ & $\begin{array}{r}92990 \\
75307 \\
3531 \\
1380557\end{array}$ \\
\hline 1296540 & 0 & 1296540 & 8.85 & 114719 & 1411259 & 10 & 141127 & 1552385 \\
\hline $\begin{array}{r}6552000 \\
4244885 \\
91390\end{array}$ & $\begin{array}{l}0 \\
0 \\
0\end{array}$ & $\begin{array}{r}6552000 \\
4244885 \\
91390\end{array}$ & $\begin{array}{l}0.00 \\
0.08 \\
2.94\end{array}$ & $\begin{array}{r}30 \\
3232 \\
2686\end{array}$ & $\begin{array}{r}6552000 \\
4248117 \\
94076\end{array}$ & $\begin{array}{r}0 \\
0 \\
10\end{array}$ & $\begin{array}{r}0 \\
20912 \\
9407\end{array}$ & $\begin{array}{r}6552000 \\
4269029 \\
103485\end{array}$ \\
\hline
\end{tabular}

1009 QUALITY ASSURANCE - TITLE!

1002 QUALITY ASSURANCE - TITLE
1003 QUALITY ASSURAKCE - CONST.

SUBJOTAL 10 QUALITYASSURANCE

SUBTOTAL I PROJECT MAMAGEMEKT

\section{A01 AIR PERMITTING \\ 2AO2 PART B DANGEROUS HASTE PERMITS \\ $2 A 03$ PRE-OP OEIERMIHATION \\ $2 B D O$ SAFETY ANALYSIS}

SUBTOTAL 2 . PERMITTIHG SAFEIY

3AOO PROJECT DEFIHITION

3 BOO PROJECT MANAGEMENT SUPPORT

3 POO PROJECT MANAGENENT SUPPORT
3 CIO DESIGN \& CONSTR. SUPPORT
91390 
KAISER ENGIHEERS HAHFORD

WEST I HGHOUSE HAKFORD COHPANY

JOB NO. W314BAC?

\begin{tabular}{|c|c|}
\hline $\begin{array}{l}\text { NBS } \\
=E x=x\end{array}$ & 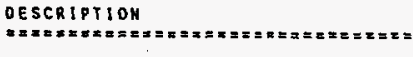 \\
\hline $\begin{array}{l}3620 \\
3630 \\
3010 \\
3020 \\
3030 \\
3040 \\
3000 \\
3600 \\
3600 \\
3600 \\
3100 \\
3000 \\
3 \times 001 \\
3 \times 00\end{array}$ & $\begin{array}{l}\text { DESIGN \& CONSTR. SUPPORT } \\
\text { DESIGN \& CONSTR. SUPPORT } \\
\text { ENGINEERIHG REPORT } \\
\text { OCBL } \\
\text { COHCEPTUAL OESIGH } \\
\text { ACDR } \\
\text { PRELIM SAFETY DOC } \\
\text { PERHITIING PLAN } \\
\text { HEPA DOCUHENTATION } \\
\text { A/E SELECTIOH \& PROCUREMEHT } \\
\text { OAPP } \\
\text { SITE CHARACTERIZATIOH } \\
\text { STARTUP SUPPORT } \\
\text { STARTUP ENGIUEERING- AH }\end{array}$ \\
\hline
\end{tabular}

$\stackrel{?}{1}$

\begin{abstract}
SUBTOTAL 3 KO STARTUP - AN
\end{abstract}

\section{K11 SIARTUP SUPPORT
3K12 SIARTUP ENGINEERING - APP}

SUBTOTAL $3 K I$ STARTUP - AP

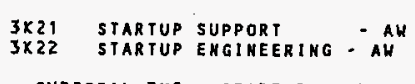

SUBTOTAL $3 K 2$ STARTUP - AK

\begin{abstract}
$3 \times 31$
$3 \times 32$ STARTUP SUPPORT
STARTUP ENGINEERING - AYY
SUBTOTAL 3K3 STARTUP - AY
\end{abstract}

$3 K 43$
$3 K 4 Z$ SIARTUP SUPPORT
SIARTUP ENGINEERING - AZ

SUBTOTAL $3 \times 4$ SIARTUP - AZ

3K5I SIARTUP SUPPORT - SY
** IEST - InTERactive estimatiKg **

TAHK FARM RESTORATIOH ANO SAFE OPERATIOHS

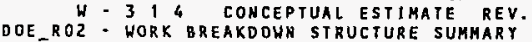

\begin{tabular}{|c|c|c|c|c|c|c|c|c|}
\hline $\begin{array}{l}\text { ESTIMATE } \\
\text { SUBTOTAL } \\
==x===\equiv=\end{array}$ & $\begin{array}{l}\text { OHSITE } \\
\text { INOIRECTS } \\
==\equiv=\equiv=\equiv==\end{array}$ & 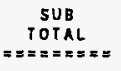 & $\begin{array}{l}\text { ESCA } \\
\mathbf{X} \\
=\approx==\end{array}$ & $\begin{array}{l}\text { ATION } \\
\text { TOTAL } \\
=====\equiv=\pi\end{array}$ & $\begin{array}{c}\text { SUB } \\
\text { TOTAL } \\
==\approx \varepsilon=\approx===\end{array}$ & 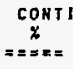 & $\begin{array}{l}\text { NGENCY } \\
\text { TOTAL } \\
=\approx \approx==\pi=\approx \approx\end{array}$ & $\begin{array}{c}\text { TOTAL } \\
\text { DOLLARS } \\
========x\end{array}$ \\
\hline $\begin{array}{r}925324 \\
4735055 \\
208000 \\
9535000 \\
560000 \\
2026000 \\
255000 \\
18000 \\
178346 \\
111000 \\
104133 \\
289228 \\
1522147 \\
982443\end{array}$ & $\begin{array}{l}0 \\
0 \\
0 \\
0 \\
0 \\
0 \\
0 \\
0 \\
0 \\
0 \\
0 \\
0 \\
0 \\
0\end{array}$ & $\begin{array}{r}925324 \\
4735055 \\
208000 \\
9535000 \\
560000 \\
2026000 \\
255000 \\
18000 \\
178346 \\
111000 \\
104133 \\
289228 \\
1522147 \\
982443\end{array}$ & $\begin{array}{r}12.07 \\
14.53 \\
0.00 \\
0.00 \\
0.00 \\
0.77 \\
0.00 \\
0.00 \\
1.24 \\
0.00 \\
0.17 \\
8.61 \\
19.70 \\
18.77\end{array}$ & $\begin{array}{r}111717 \\
687960 \\
0 \\
0 \\
0 \\
15700 \\
0 \\
0 \\
2219 \\
0 \\
175 \\
24909 \\
299883 \\
184423\end{array}$ & $\begin{array}{r}1037041 \\
5423015 \\
208000 \\
9535000 \\
560000 \\
2041700 \\
255000 \\
18000 \\
180565 \\
111000 \\
104308 \\
314137 \\
1822030 \\
1166866\end{array}$ & $\begin{array}{r}10 \\
10 \\
0 \\
0 \\
0 \\
5 \\
0 \\
0 \\
8 \\
0 \\
1 \\
10 \\
10 \\
10\end{array}$ & $\begin{array}{r}103703 \\
542302 \\
0 \\
0 \\
0 \\
101570 \\
0 \\
0 \\
14357 \\
0 \\
1131 \\
31413 \\
182203 \\
116686\end{array}$ & $\begin{array}{r}1160744 \\
5965317 \\
208000 \\
9535000 \\
560000 \\
2143270 \\
255000 \\
18000 \\
194922 \\
111000 \\
105439 \\
345552 \\
2004231 \\
1283552\end{array}$ \\
\hline 2504590 & 0 & 2504590 & 19.34 & 484306 & 2988896 & 10 & $298 \mathrm{B8} 9$ & 3287783 \\
\hline $\begin{array}{l}1505042 \\
1005290\end{array}$ & $\begin{array}{l}0 \\
0\end{array}$ & $\begin{array}{l}1505042 \\
1005290\end{array}$ & $\begin{array}{l}22.87 \\
21.53\end{array}$ & $\begin{array}{l}344141 \\
216465\end{array}$ & $\begin{array}{l}1849183 \\
1221755\end{array}$ & $\begin{array}{l}10 \\
10\end{array}$ & $\begin{array}{l}184920 \\
122175\end{array}$ & $\begin{array}{l}2034102 \\
1343931\end{array}$ \\
\hline 2510332 & 0 & 2510332 & 22.33 & 560606 & 3070938 & 10 & 307095 & .3378033 \\
\hline $\begin{array}{r}1510634 \\
999609\end{array}$ & $\begin{array}{l}0 \\
0\end{array}$ & $\begin{array}{r}1510634 \\
999609\end{array}$ & $\begin{array}{l}11.42 \\
10.12\end{array}$ & $\begin{array}{l}172584 \\
101205\end{array}$ & $\begin{array}{l}1683218 \\
1100814\end{array}$ & $\begin{array}{l}10 \\
10\end{array}$ & $\begin{array}{l}168321 \\
110081\end{array}$ & $\begin{array}{l}1851539 \\
1210895\end{array}$ \\
\hline 2510243 & 0 & 2510243 & 10.91 & 273789 & 2784032 & 10 & 278402 & 3062636 \\
\hline $\begin{array}{l}524897 \\
845358\end{array}$ & $\begin{array}{l}0 \\
0\end{array}$ & $\begin{array}{l}526897 \\
845358\end{array}$ & $\begin{array}{l}15.87 \\
17.25\end{array}$ & $\begin{array}{r}83322 \\
145842\end{array}$ & $\begin{array}{l}608219 \\
991200\end{array}$ & $\begin{array}{l}10 \\
10\end{array}$ & $\begin{array}{l}60821 \\
99120\end{array}$ & $\begin{array}{r}669040 \\
1090320\end{array}$ \\
\hline 1370255 & 0 & 1370255 & 16.72 & 229164 & 1599419 & 10 & 159941 & 1759360 \\
\hline $\begin{array}{l}524897 \\
845358\end{array}$ & $\begin{array}{l}0 \\
0\end{array}$ & $\begin{array}{l}524897 \\
845358\end{array}$ & $\begin{array}{l}15.87 \\
17.25\end{array}$ & $\begin{array}{r}83322 \\
145842\end{array}$ & $\begin{array}{l}608219 \\
991200\end{array}$ & $\begin{array}{l}10 \\
10\end{array}$ & $\begin{array}{l}60821 \\
99120\end{array}$ & $\begin{array}{r}569040 \\
1090320\end{array}$ \\
\hline 1370255 & 0 & 1370255 & 16.72 & 229164 & 1599419 & 10 & 159941 & 1759360 \\
\hline 1403058 & 0 & 1403058 & 13.01 & 182480 & 1585538 & 10 & 158554 & 1744091 \\
\hline
\end{tabular}

PAGE 3 OF 84

DATE 04/23/96 14:56:2

BY TLH ROP OKH JSH 
KAISER ENGIHEERS HANFORD WESTIMGHOUSE HAKFORD COMPANY JOB NO. HS14BAC2

WBS DESCRIPTION

$3 K 52$ STARTUP EHGINEERING - SY

SUBTOTAL $3 \times 5$ STARTUP - SY

3K61 STARTUP SUPPORT

KG2 STARTUP ENGINEERING - 244

SUBTOTAL 3 KG STARTUP - 244 A

$\begin{array}{ll}3 \times 71 & \text { STARTUP SUPPORT } \\ 3 \times 72 & \text { STARTUP ENGIHEERING }-244 \mathrm{~s}\end{array}$

$?$ SUBTOTAL $3 K T$ SIARTUP $244 \mathrm{~s}$

$3 K 81$
$3 K B 2$ SIARTUP SUPPORT
3 STARTUP ENGINEERIHG -200 E/H

SUBTOTAL $3 K 8$ STARTUP - 200 E/U

$3 \times 99$ STARTUP SUPPORT
$3 \times 92$ SIARTUP ENGINEERING - SST

SUBTOTAL $3 K 9$ STARTUP - SST

3XAO STARTUP AOMINISTRATION

SUBTOIAL 3KA SIARTISP AOMINISTRATION

SUBTOTAL. $3 K$ SIARTUP

$3 L 01$ READINESS REVIEH - AN

$3 L 11$ READINESS REVIEH - AP

$3 L 21$
$3 L 31$

$\begin{array}{ll}3 L 31 & \text { REAOINESS REVIEN - AY } \\ 3 L 4 T \text { REAOINESS REVIEH - AZ }\end{array}$
* IEST - INTERACTIVE ESTIMATING *

TANK FARM RESTORATION AND SAFE OPERATIONS DOE - 31 " CONCEPTUAL ESTIMATE REV.

\begin{tabular}{|c|c|}
\hline $\begin{array}{l}\text { ESTIMATE } \\
\text { SUB TOTAL } \\
z======\end{array}$ & $\begin{array}{l}\text { ONSITE } \\
\text { I WD I REC } \\
=====\end{array}$ \\
\hline 936748 & \\
\hline 2339806 & \\
\hline $\begin{array}{l}879835 \\
485540\end{array}$ & \\
\hline 1365375 & \\
\hline $\begin{array}{l}879835 \\
485540\end{array}$ & \\
\hline 1365375 & \\
\hline $\begin{array}{l}382865 \\
285504\end{array}$ & \\
\hline 688459 & \\
\hline $\begin{array}{r}211510 \\
97133\end{array}$ & \\
\hline 308643 & \\
\hline 3136015 & \\
\hline 3136015 & \\
\hline 19449348 & \\
\hline $\begin{array}{r}1010884 \\
1009247 \\
1036160 \\
811210 \\
811865\end{array}$ & \\
\hline
\end{tabular}

PAGE 4 OF 84

DATE O4/23/96 $14: 56: 21$

BY TLN ROP OKH JJM

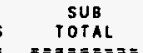

936748

ESCALATION

$x$ TOTAL

$13.07 \quad 122453$

2339806

13.03

304933

0
0 $\quad 879835 \quad 11.13 \quad 97916$

$\begin{array}{rrr}879835 & 11.13 & 97916 \\ 485540 & 5.64 & 27370\end{array}$

1365375

0.18

125286

879835

485540

1365375

.

3028

382865
285594

668459

668459

211510

308643

11.13

5.64

97916

9. 18

125286

10.02

10.02
8.57

38363

8.5457915

9.86
5.97

20864

8.6

26662

3136035

15.6

3136015

15.

19449348

14.94

1010884
1009247
1036140
811210
811865

sus TOIAL.

CONTIHGEHCY $x$ TOTAL

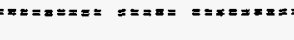

$1059201 \quad 10 \quad 105920$

264474

$2644739 \quad 10$

977751
512910

$1490661 \quad 10$

97775
51291

149066

$\begin{array}{ll}977751 & 10 \\ 512910 & 10\end{array}$

169066110

97775
5129

149066

$421228 \quad 10$

42123

30435

72558

$725574 \quad 10$

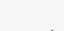

$232374 \quad 10$

23237
10293

33530

362630

362630

2235592

2235592

. 122926 125686 115944 92922
92994
TOTAL

Dollars

1165121

2909212

1075527 564201

1639728

1075527

564201

1639728

463351

334781

798132

255610

113223

368833

3988939

3988939

24591542

1352186 1382550

1275387 1022138 
KAISER ENGIMEERS HANFORD

WESTIMGHOUSE HAHFORD COMPANY

\section{WBS DESCRIPTIOH}

3 359 REAOINESS REVIEY - SY

3169 REAOIMESS REVIEH: 244 A

3271 READIHESS REVIEN -244 S
$3 L 81$ READINESS REVIEW $=200$ EIN

$3 L 99$ READINESS REVIEW - SST

SUBTOTAL $3 L$ READIHESS REVIEH

3MOI IND REV. SYSTEMS ENG. MGMT. - FY QB 3MO2 IHD. REV.SYSTEMS EHG. NGMT: - FY 9

3MO3 INO. REV.SYSTEMS EMG. HGMT. - FYOO

3MO4 INO. REV.SYSTEMS EHG. KGMT. FY O1

$3 M 05$ INO. REV.SYSIERS EHG. MGKT. - FY 02

I 3NO6 IND. REV.SYSTEMS EHG. MGHT. - FY OL

SUBTOTAL 3M INOEPEHDENT REVIEUS

SUBTOTAL 3 OPC ACTIVITIES

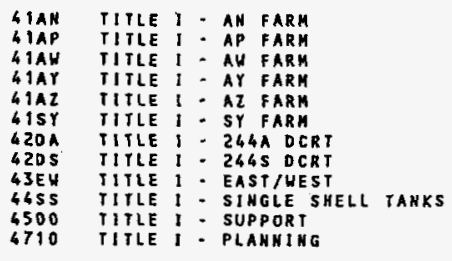

SUBTOTAL 4 TITLE I DESIGN

SAII TITLE II - AN FARH

5AI2 DISC 35.65 SUPPORT ACIIVITIES

SUBTOTAL SAT TITLE H - M
* * IEST - INTERACTIVE ESTIMATIHG * *

TANK FARM RESTORATION AND SAFE OPERATIONS - 314 CONCEPTUAL ESTIMATE REV. DOE_ROZ - WORK BREAKDOHN STRUCTURE SUMMARY

\begin{tabular}{|c|c|c|c|c|c|c|c|c|}
\hline $\begin{array}{l}\text { ESTIMA IE } \\
\text { SUB TOTAL } \\
======\approx\end{array}$ & $\begin{array}{l}\text { ONSITE } \\
\text { INDIRECTS } \\
=====\equiv==\end{array}$ & $\begin{array}{c}\text { SUB } \\
\text { TOTAL } \\
===\approx==z=x\end{array}$ & $== \pm=x=$ & $\begin{array}{l}\text { ALATION } \\
\text { TOTAL } \\
=x==x=x=\end{array}$ & $\begin{array}{c}\text { SUB } \\
\text { TOTAL } \\
==\Rightarrow=\equiv=\equiv==\end{array}$ & $\begin{array}{c}\operatorname{con} T \\
x \\
=x=\infty\end{array}$ & $\begin{array}{l}\text { INGENCY } \\
\text { TOTAL } \\
=\approx==\approx=\approx \approx=\end{array}$ & $\begin{array}{c}\text { TOTAL } \\
\text { DOLLARS } \\
==x=\equiv==x=\end{array}$ \\
\hline $\begin{array}{l}994009 \\
763701 \\
763701 \\
484599 \\
120423\end{array}$ & $\begin{array}{l}0 \\
0 \\
0 \\
0 \\
a\end{array}$ & $\begin{array}{l}994009 \\
763701 \\
763701 \\
484599 \\
120423\end{array}$ & $\begin{array}{r}15.44 \\
8.06 \\
9.09 \\
10.02 \\
6.08\end{array}$ & $\begin{array}{r}153427 \\
61549 \\
68844 \\
68557 \\
8282\end{array}$ & $\begin{array}{r}1147436 \\
825250 \\
832545 \\
533156 \\
128705\end{array}$ & $\begin{array}{l}10 \\
10 \\
10 \\
10 \\
10\end{array}$ & $\begin{array}{r}114744 \\
82525 \\
83255 \\
53316 \\
12870\end{array}$ & $\begin{array}{r}1262180 \\
907775 \\
915799 \\
586471 \\
141576\end{array}$ \\
\hline 7805779 & 0 & 7805779 & 14.84 & 1166035 & 8971814 & 10 & 897132 & 9868993 \\
\hline $\begin{array}{r}160000 \\
260000 \\
180000 \\
220000 \\
100000 \\
20000 \\
20000\end{array}$ & $\begin{array}{l}0 \\
0 \\
0 \\
0 \\
0 \\
0 \\
0\end{array}$ & $\begin{array}{r}160000 \\
260000 \\
180000 \\
220000 \\
100000 \\
20000 \\
20000\end{array}$ & $\begin{array}{r}4.31 \\
7.13 \\
10.02 \\
12.99 \\
16.04 \\
25.69 \\
30.00\end{array}$ & $\begin{array}{r}6896 \\
18538 \\
18036 \\
28578 \\
16040 \\
5138 \\
6000\end{array}$ & $\begin{array}{r}166896 \\
278538 \\
198036 \\
248578 \\
116040 \\
25138 \\
26000\end{array}$ & $\begin{array}{l}10 \\
10 \\
10 \\
10 \\
10 \\
10 \\
10\end{array}$ & $\begin{array}{r}16690 \\
27854 \\
19804 \\
24858 \\
11604 \\
2514 \\
2600\end{array}$ & $\begin{array}{r}183586 \\
306392 \\
217840 \\
273436 \\
127644 \\
27652 \\
28600\end{array}$ \\
\hline 960000 & 0 & 960000 & 10.34 & 99226 & 1059226 & 10 & $105924^{\circ}$ & 1165150 \\
\hline 58048488 & 0 & 58048488 & 8.65 & 5020463 & 63068951 & 6 & 4063493 & 67132443 \\
\hline $\begin{array}{r}379273 \\
187687 \\
148321 \\
83586 \\
101538 \\
139864 \\
145457 \\
99216 \\
179284 \\
49867 \\
2537884 \\
1116246\end{array}$ & $\begin{array}{l}0 \\
0 \\
0 \\
0 \\
0 \\
0 \\
0 \\
0 \\
0 \\
0 \\
0 \\
0\end{array}$ & $\begin{array}{r}379273 \\
187687 \\
148321 \\
83586 \\
181538 \\
139864 \\
145457 \\
99218 \\
179284 \\
49867 \\
2537884 \\
1116246\end{array}$ & $\begin{array}{l}3.93 \\
3.93 \\
3.93 \\
3.93 \\
3.93 \\
3.93 \\
3.93 \\
3.93 \\
3.93 \\
3.93 \\
3.49 \\
3.93\end{array}$ & $\begin{array}{r}14905 \\
7375 \\
5829 \\
3284 \\
3990 \\
5496 \\
5717 \\
3900 \\
7045 \\
1960 \\
88489 \\
43867\end{array}$ & $\begin{array}{r}394178 \\
195062 \\
154150 \\
86870 \\
105528 \\
145360 \\
151174 \\
103118 \\
186329 \\
51827 \\
2626373 \\
1160113\end{array}$ & $\begin{array}{l}15 \\
15 \\
15 \\
15 \\
15 \\
15 \\
15 \\
15 \\
15 \\
15 \\
15 \\
15\end{array}$ & $\begin{array}{r}59126 \\
29259 \\
23122 \\
13032 \\
15830 \\
21802 \\
22676 \\
15466 \\
27948 \\
7774 \\
393954 \\
174017\end{array}$ & $\begin{array}{r}453304 \\
224323 \\
177272 \\
99909 \\
121357 \\
167164 \\
173851 \\
118586 \\
214280 \\
59600 \\
3020330 \\
1334131\end{array}$ \\
\hline 5168225 & 0 & 5168225 & 3.71 & 191857 & 5360082 & 15 & 804006 & 6164099 \\
\hline $\begin{array}{r}2785094 \\
963857\end{array}$ & o & $\begin{array}{r}2785094 \\
963857\end{array}$ & $\begin{array}{l}15.68 \\
15.68\end{array}$ & $\begin{array}{l}636704 \\
151131\end{array}$ & $\begin{array}{l}3221798 \\
1114988\end{array}$ & $\begin{array}{l}20 \\
20\end{array}$ & $\begin{array}{l}644358 \\
222908\end{array}$ & $\begin{array}{l}3866157 \\
1337967\end{array}$ \\
\hline 3748951 & 0 & 3748951 & 15.68 & 587835 & 4336786 & 20 & 867356 & 5204144 \\
\hline
\end{tabular}

PAGE 5 OF 84

$14: 56: 22$

BY TLN RDP OKH JJH 
KAISER ENGINEERS KANFORD WESTIHGHOUSE HANFORD COMPANY

JOB HO. W314BAC?

WBS DESCRIPIION

$5 A 21$ TITLE HI AN

SUETOTAL SA2 TITLE III. AH

SASA ADVANCE PROCUREHEHT INSTRUHENTATION SA3B PRIMARY VENT SYS ADVAHCEO PRCHT

SUBTOTAL SA3 ADVANCEO PROCUREMENT

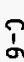

SA4A TAHK 101

SA4B TAHK 102
$5 A 4 C$
TAKK 103

SA4D TARK 104

SAGE TANK 105

5A4F TANX 106

SAGI TAHK 107 TEQUTREMEHTS

SALS SITE WORK

SALK TAKK 1OI. VALVE PIT AN-A

5AGL TANK 101 - VALVE PIT . AN=B

SUBTOTAL 5AG CONSTRUCTION FORCES

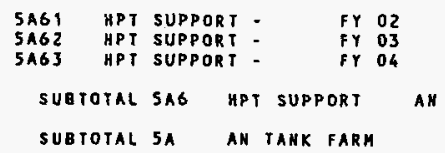

5BII TITLE II - AP FARM

$5 B 11$ IITLE II
5812 OP FARM
DISC $35-65$ SUPPORT ACTIVITIES

SUBTOTAL 5 B TITLE II - AP
* IEST - INTERACTIVE ESTIHATING * *

IANK FARM RESTORATIOH ANO SAFE OPERATIONS $W-394$ CONCEPTUAL ESTIMATE REV.
DOE RO2 - WORK BREAKDOWK STRUCTURE SUMMARY

\begin{tabular}{|c|c|c|c|c|c|c|c|c|}
\hline $\begin{array}{l}\text { ESTIMATE } \\
\text { SUBTOTAL } \\
=\approx \equiv=\approx===\end{array}$ & $\begin{array}{l}\text { ONSITE } \\
\text { INDIRECIS } \\
=======\Rightarrow\end{array}$ & $\begin{array}{c}\text { SUB } \\
\text { TOTAL } \\
\Rightarrow=\approx=\equiv=\equiv=\equiv\end{array}$ & $===\stackrel{\begin{array}{l}E S C A \\
x\end{array}}{=}=$ & $\begin{array}{l}\text { LATION } \\
\text { TOTAL } \\
===\equiv=\pi==\end{array}$ & $\begin{array}{c}\text { SUB } \\
\text { TOTAL } \\
\Rightarrow==x=x=x=\pi\end{array}$ & $\begin{array}{c}\operatorname{cONTI} \\
=x \\
=x= \pm\end{array}$ & $\begin{array}{l}\text { IHGENCY } \\
\text { IOTAL } \\
=\approx==\equiv=\equiv= \pm\end{array}$ & $\begin{array}{c}\text { TOTAL } \\
\text { DOLLARS } \\
==x= \pm==x \approx\end{array}$ \\
\hline 2429600 & 0 & 2428600 & 20.93 & 508515 & 2938115 & 20 & 587625 & 3525739 \\
\hline 2429600 & 0 & 2429600 & 20.93 & 508515 & 2938115 & 20 & 587625 & 3525739 \\
\hline $\begin{array}{l}741394 \\
710675\end{array}$ & $\begin{array}{l}0 \\
0\end{array}$ & $\begin{array}{l}741394 \\
710675\end{array}$ & $\begin{array}{r}17.41 \\
17.41\end{array}$ & $\begin{array}{l}129077 \\
123729\end{array}$ & $\begin{array}{l}870471 \\
834404\end{array}$ & $\begin{array}{l}25 \\
25\end{array}$ & $\begin{array}{l}217618 \\
208601\end{array}$ & $\begin{array}{l}1088088 \\
1043004\end{array}$ \\
\hline 1452069 & 0 & 1452069 & $17.4 \%$ & 252806 & 1704875 & 25 & 426219 & 2131092 \\
\hline $\begin{array}{r}717979 \\
688709 \\
568071 \\
566567 \\
565954 \\
672716 \\
689039 \\
3187789 \\
3534871 \\
590195 \\
606879\end{array}$ & $\begin{array}{l}0 \\
0 \\
0 \\
0 \\
0 \\
0 \\
0 \\
0 \\
0 \\
0 \\
0\end{array}$ & $\begin{array}{r}717979 \\
688709 \\
566071 \\
566567 \\
565954 \\
672716 \\
689039 \\
3187789 \\
3534871 \\
590195 \\
606879\end{array}$ & $\begin{array}{l}22.13 \\
22.13 \\
22.13 \\
22.13 \\
22.13 \\
22.13 \\
22.13 \\
22.13 \\
22.13 \\
22.13 \\
22.13\end{array}$ & $\begin{array}{l}158890 \\
152412 \\
125272 \\
125383 \\
125245 \\
148872 \\
152486 \\
705460 \\
782267 \\
130611 \\
134301\end{array}$ & $\begin{array}{r}876869 \\
841121 \\
691343 \\
691950 \\
691199 \\
821588 \\
841525 \\
3893249 \\
4317138 \\
720806 \\
741172\end{array}$ & $\begin{array}{l}30 \\
30 \\
30 \\
30 \\
30 \\
30 \\
30 \\
30 \\
28 \\
35 \\
35\end{array}$ & $\begin{array}{r}263060 \\
252336 \\
207404 \\
207586 \\
207360 \\
246476 \\
252456 \\
1167975 \\
1198082 \\
250403 \\
257935\end{array}$ & $\begin{array}{r}1139929 \\
1093457 \\
898748 \\
899535 \\
898562 \\
1068066 \\
1093981 \\
5061221 \\
5515217 \\
971210 \\
999107\end{array}$ \\
\hline 12386761 & 0 & 12386761 & 22.13 & 2741199 & 15127960 & 30 & 4511073 & 19639033 \\
\hline $\begin{array}{r}64820 \\
259185 \\
259185\end{array}$ & $\begin{array}{l}0 \\
0 \\
0\end{array}$ & $\begin{array}{r}64820 \\
259185 \\
259185\end{array}$ & $\begin{array}{l}16.04 \\
19.17 \\
22.39\end{array}$ & $\begin{array}{l}10397 \\
49686 \\
58032\end{array}$ & $\begin{array}{r}75217 \\
308671 \\
317217\end{array}$ & $\begin{array}{l}10 \\
10 \\
10\end{array}$ & $\begin{array}{r}7522 \\
30887 \\
31722\end{array}$ & $\begin{array}{r}82739 \\
339758 \\
348938\end{array}$ \\
\hline 583190 & 0 & 583190 & 20.25 & 118115 & 701305 & 10 & 70131 & 771635 \\
\hline 20600571 & 0 & 20800579 & 20.43 & 6208470 & 24809041 & 26 & 6462404 & 31271443 \\
\hline $\begin{array}{r}2293977 \\
931337\end{array}$ & $\begin{array}{l}0 \\
0\end{array}$ & $\begin{array}{r}2293977 \\
931337\end{array}$ & $\begin{array}{l}17.12 \\
17.12\end{array}$ & $\begin{array}{l}392727 \\
159446\end{array}$ & $\begin{array}{l}2686704 \\
1090783\end{array}$ & $\begin{array}{l}20 \\
20\end{array}$ & $\begin{array}{l}537338 \\
218156\end{array}$ & $\begin{array}{l}3224050 \\
1308937\end{array}$ \\
\hline 3225314 & 0 & 3225314 & 17.12 & 552173. & 3777487 & 20 & 755494 & 4532987 \\
\hline
\end{tabular}

PAGE 6 OF 84

T4/23/80 $14: 56: 22$
BY TLH RDP OKH JJH 
KAISER ENGINEERS HAHFORD

WESIIHGHOUSE HAMFORD COMPAUY

JOB HO. H314BAC2

\section{WBS DESCRIPTIOH}

$5 B 21$ TITLE III AP

SUBTOTAL 582 TIBLE III AP

5B3A AOVAKCE PROCUREMEHT INSIRUMENTATION 5B3B PRIMARY VENT SYS ADVANCED PRCHT

SUBTOTAL $5 B 3$ AOYAHCE PROCUREMENT

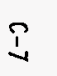

$\begin{array}{ll}\text { 5B4A } & \text { TANK } 101 \\ 5848 & \text { TANK } 102 \\ 584 C & \text { TAHK } 103 \\ 5840 & \text { TANK } 104 \\ 5 B 4 E & \text { TAHK } 105 \\ 584 F & \text { TAHK } 106 \\ 5 B 46 & \text { TANK } 107 \\ 584 H & \text { TANK } 108 \\ 584 ! & \text { GENERAL REQUIREMENTS } \\ 584 \text { SITE HORK } \\ 5 B 4 K & \text { VALVE PIT AP }\end{array}$

SBAK VALVE PIT AP

SUBTOTAL 5 BG CONSTRUCTION FORCES

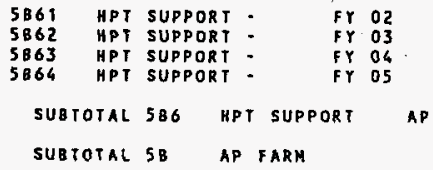

SC11 TIILE II- AH FARM
SCII DISC $35-65$ SUPPORT-ACTIVITIES

SUBTOTAL 5CI TITLE IS. AH
* IEST - INTERACTIVE ESTIMATIKG ** TAMK FARM RESTORATION AND SAFE OPERATIOHS H - 314 CONCEPTUAL ESTIMATE REV. 1 OOE_ROZ - HORK SREAKDOWH STRUCTURE SUMMARY
PAGE 7 OF 84

DATE O4/23/96 $14: 56: 2$

BY TEW RDP DKH JJM

\begin{tabular}{|c|c|c|c|c|c|c|c|c|}
\hline $\begin{array}{l}\text { ESTTMATE } \\
\text { SUBTOTAL } \\
=======\end{array}$ & $\begin{array}{l}\text { ONSITE } \\
\text { J HD IRECT\$ } \\
======\equiv==\end{array}$ & $\begin{array}{c}\text { SUB } \\
\text { IOTAL } \\
=\approx==\approx====\end{array}$ & 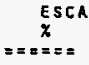 & $\begin{array}{l}\text { LATION } \\
\text { TOTAL } \\
=\varepsilon=x=\varepsilon=\varepsilon\end{array}$ & 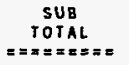 & $\begin{array}{l}\operatorname{conTI} \\
== \pm=\end{array}$ & $\begin{array}{l}\text { HGENCY } \\
\text { JOTAL } \\
==\approx==z \approx=z\end{array}$ & $\begin{array}{c}\text { JOIAL } \\
\text { DOLLARS } \\
===\pi=\pi \approx=\end{array}$ \\
\hline 1778622 & 0 & 1778622 & 22.73 & 404282 & 2182904 & 20 & 436580 & 2619482 \\
\hline 1778622 & 0 & 1778622 & 22.73 & 406282 & 2982904 & 20 & 436580 & 2619482 \\
\hline $\begin{array}{r}1355706 \\
710675\end{array}$ & $\begin{array}{l}0 \\
0\end{array}$ & $\begin{array}{r}1355706 \\
710675\end{array}$ & $\begin{array}{l}18.86 \\
18.86\end{array}$ & $\begin{array}{l}255686 \\
134033\end{array}$ & $\begin{array}{r}1611392 \\
844708\end{array}$ & $\begin{array}{l}25 \\
25\end{array}$ & $\begin{array}{l}402848 \\
211177\end{array}$ & $\begin{array}{l}2014240 \\
1055885\end{array}$ \\
\hline 2066381 & 0 & 2066381 & 18.86 & 3897.18 & 2456100 & 25 & 614025 & 3070125 \\
\hline $\begin{array}{r}621669 \\
911302 \\
699941 \\
620430 \\
693750 \\
624074 \\
617632 \\
617859 \\
2367628 \\
4893232 \\
631213\end{array}$ & $\begin{array}{l}0 \\
0 \\
0 \\
0 \\
0 \\
0 \\
0 \\
0 \\
0 \\
0 \\
0\end{array}$ & $\begin{array}{r}621669 \\
911302 \\
699941 \\
620430 \\
693750 \\
624074 \\
617632 \\
617859 \\
2367628 \\
4893232 \\
631213\end{array}$ & $\begin{array}{l}23.64 \\
23.64 \\
23.64 \\
23.64 \\
23.64 \\
23.64 \\
23.64 \\
23.84 \\
23.64 \\
23.64 \\
23.64\end{array}$ & $\begin{array}{l}146964 \\
215433 \\
165469 \\
146672 \\
164005 \\
147533 \\
146010 \\
146065 \\
559707 \\
1956759 \\
149221\end{array}$ & $\begin{array}{r}768633 \\
1126735 \\
865410 \\
767102 \\
857755 \\
771607 \\
763642 \\
763924 \\
2927335 \\
6049991 \\
780434\end{array}$ & $\begin{array}{l}30 \\
30 \\
30 \\
30 \\
30 \\
30 \\
30 \\
30 \\
35 \\
28 \\
35\end{array}$ & $\begin{array}{c}230590 \\
338022 \\
259623 \\
230130 \\
257326 \\
231482 \\
229092 \\
229177 \\
1022161 \\
1675078 \\
271659 \\
.\end{array}$ & $\begin{array}{r}999220 \\
1464753 \\
1125030 \\
997229 \\
1115080 \\
1003087 \\
992732 \\
993096 \\
3949495 \\
7725069 \\
1052089\end{array}$ \\
\hline 13298730 & D & 13298730 & 23.64 & 3143838 & 16442568 & 30 & 4974340 & 21416880 \\
\hline $\begin{array}{r}21622 \\
259185 \\
259185 \\
194412\end{array}$ & $\begin{array}{l}0 \\
0 \\
0 \\
0\end{array}$ & $\begin{array}{r}21622 \\
259185 \\
259185 \\
194412\end{array}$ & $\begin{array}{l}16.04 \\
19.17 \\
22.39 \\
25.69\end{array}$ & $\begin{array}{r}3468 \\
49686 \\
58032 \\
49944\end{array}$ & $\begin{array}{r}25090 \\
308871 \\
317217 \\
244356\end{array}$ & $\begin{array}{l}10 \\
10 \\
10 \\
10\end{array}$ & $\begin{array}{r}2509 \\
30887 \\
31722 \\
24436\end{array}$ & $\begin{array}{r}27599 \\
339758 \\
348938 \\
268792\end{array}$ \\
\hline 734404 & 0 & 734404 & 21.94 & 161130 & 895534 & 10 & 89554 & 985087 \\
\hline 21103451 & 0 & 21103451 & 22.04 & 4651142 & 25754593 & 27 & 6869993 & 32624561 \\
\hline $\begin{array}{l}2398717 \\
1010033\end{array}$ & $\begin{array}{l}0 \\
0\end{array}$ & $\begin{array}{l}2398717 \\
1090033\end{array}$ & $\begin{array}{l}6.75 \\
6.75\end{array}$ & $\begin{array}{r}161911 \\
68178\end{array}$ & $\begin{array}{l}2560628 \\
1078211\end{array}$ & $\begin{array}{l}20 \\
20\end{array}$ & $\begin{array}{l}512128 \\
215641\end{array}$ & $\begin{array}{l}3072757 \\
1293852\end{array}$ \\
\hline 3408750 & 0 & 3408750 & 6.75 & 230089 & 3638839 & 20 & 727769 & 4366609 \\
\hline
\end{tabular}


XAISER ENGINEERS HANFORD

WESTIMGHOUSE HAHFORD COMPANY

JOB NO. H314BAC?

NBS DESCRIPTION

SC21 ITLE ITI AH

SUBTOTAL 5 C2 TITLE III AH

5C3A AOVANCE PROCUREMENT INSTRUAENTATION 5 C3B. PRIMARY VENT SYS ADVANCED PRCMT

SUBTOTAL SC3 PROCUREMENT AH

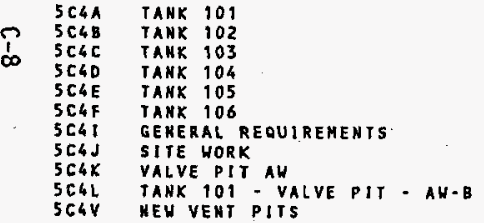

SUBTOTAL SCG CONSTRUCIIOH FORCES

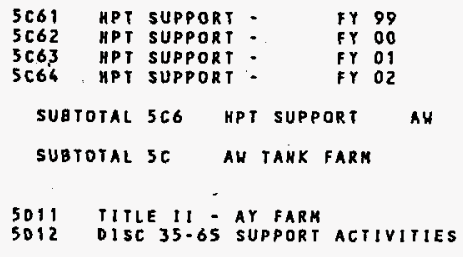

SUBTOTAL 5DI TITLE II - AY FARM
* : IEST - JHTERACTIVE ESTIMATING *

TANK FARH RESTORATION AHD SAFE OPERATIONS

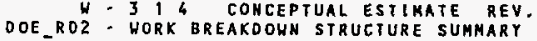

PAGE 8 OF 84

$14.56 \cdot 23$

IY TLH RDP OKH JJM

\begin{tabular}{|c|c|c|c|c|c|c|c|c|}
\hline $\begin{array}{l}\text { ESTIMATE } \\
\text { SUBTOTAL } \\
====\approx=\approx\end{array}$ & $\begin{array}{l}\text { ONSITE } \\
\text { INDIRECTS } \\
========\end{array}$ & $\begin{array}{c}\text { SUB } \\
\text { IOIAL } \\
=\approx=\approx=\approx=\equiv=\end{array}$ & $=\stackrel{x}{x}_{x=2 \text { S }}$ & $\begin{array}{l}\text { LATION } \\
\text { YOTAL } \\
===\approx=\equiv=\equiv\end{array}$ & 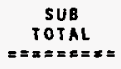 & 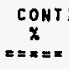 & 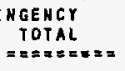 & $\begin{array}{c}\text { TOTAL } \\
\text { DOLLARS } \\
=x=x=x=x=\end{array}$ \\
\hline 1700770 & 0 & 1700770 & 10.72 & 182323 & 1883093 & 20 & 376620 & 2259713 \\
\hline 1700770 & 0 & 1700770 & 10.72 & 182323 & 1883093 & 20 & 376620 & 2259713 \\
\hline $\begin{array}{l}744522 \\
762960\end{array}$ & $\begin{array}{l}0 \\
0\end{array}$ & $\begin{array}{l}746522 \\
762960\end{array}$ & $\begin{array}{l}6.99 \\
6.99\end{array}$ & $\begin{array}{l}52042 \\
53331\end{array}$ & $\begin{array}{l}796564 \\
816291\end{array}$ & $\begin{array}{l}25 \\
25\end{array}$ & $\begin{array}{l}199141 \\
204073\end{array}$ & $\begin{array}{r}995705 \\
1020364\end{array}$ \\
\hline 1507482 & 0 & 1507482 & 6.99 & 105373 & 1612855 & 25 & 403214 & 2016069 \\
\hline $\begin{array}{r}633663 \\
1009575 \\
675599 \\
635935 \\
669408 \\
677753 \\
2174422 \\
5652186 \\
4217717 \\
423455 \\
282214\end{array}$ & $\begin{array}{l}0 \\
0 \\
0 \\
0 \\
0 \\
0 \\
0 \\
0 \\
0 \\
0 \\
0\end{array}$ & $\begin{array}{r}633663 \\
1009575 \\
675599 \\
635935 \\
669408 \\
677753 \\
2174422 \\
5652186 \\
421717 \\
423455 \\
282214\end{array}$ & $\begin{array}{l}12.59 \\
12.59 \\
12.59 \\
12.59 \\
12.59 \\
12.59 \\
12.59 \\
12.59 \\
12.59 \\
12.59 \\
12.59\end{array}$ & $\begin{array}{r}79781 \\
127110 \\
85061 \\
80066 \\
84281 \\
85332 \\
273762 \\
711610 \\
53093 \\
53312 \\
35530\end{array}$ & $\begin{array}{r}713444 \\
1136685 \\
760660 \\
716001 \\
753689 \\
763085 \\
2448184 \\
6363796 \\
474810 \\
476767 \\
317744\end{array}$ & $\begin{array}{l}30 \\
30 \\
30 \\
30 \\
30 \\
30 \\
35 \\
27 \\
35 \\
35 \\
35\end{array}$ & $\begin{array}{r}214035 \\
341005 \\
228200 \\
214802 \\
226109 \\
228928 \\
856864 \\
1744393 \\
164625 \\
165310 \\
111210\end{array}$ & $\begin{array}{r}927472 \\
1677686 \\
988853 \\
930798 \\
979792 \\
992007 \\
3305043 \\
8108188 \\
639437 \\
642079 \\
428956\end{array}$ \\
\hline 13255927 & 0 & 13255927 & 12.59 & 1668938 & 14924865 & 30 & 4495481 & 19420309 \\
\hline $\begin{array}{r}21622 \\
259185 \\
259185 \\
21622\end{array}$ & $\begin{array}{l}0 \\
0 \\
0 \\
0\end{array}$ & $\begin{array}{r}27622 \\
259185 \\
259185 \\
21622\end{array}$ & $\begin{array}{r}7.13 \\
10.02 \\
12.99 \\
16.04\end{array}$ & $\begin{array}{r}1542 \\
25970 \\
33668 \\
3468\end{array}$ & $\begin{array}{r}23164 \\
285155 \\
292853 \\
25090\end{array}$ & $\begin{array}{l}10 \\
10 \\
10 \\
10\end{array}$ & $\begin{array}{r}2316 \\
28516 \\
29285 \\
2509\end{array}$ & $\begin{array}{r}25480 \\
313671 \\
322138 \\
27599\end{array}$ \\
\hline 561614 & 0 & 561614 & 19.51 & 64648 & 626262 & 10 & 62626 & 688888 \\
\hline 20434543 & 0 & 20434543 & 11.02 & 2251371 & 22685914 & 27 & 6065710 & 28751588 \\
\hline $\begin{array}{r}1497662 \\
843261\end{array}$ & 0 & $\begin{array}{r}1497662 \\
843261\end{array}$ & $\begin{array}{l}12.31 \\
12.31\end{array}$ & $\begin{array}{l}184361 \\
103806\end{array}$ & $\begin{array}{r}1682023 \\
947067\end{array}$ & $\begin{array}{l}20 \\
20\end{array}$ & $\begin{array}{l}336404 \\
189493\end{array}$ & $\begin{array}{l}2018430 \\
1136480\end{array}$ \\
\hline 2340923 & 0 & 2340923 & 12.31 & 288167 & 2629090 & 20 & 525817 & 3154910 \\
\hline
\end{tabular}


KAISER ENGINEERS HANFORO

WESI INGHOUSE HANFORD COMPANY

JOB NO. N314BAC?

HBS DESCRIPTION

SDZI TITLE III AY

SUBTOTAL SOZ TITLE IH - AT FARA

503A AOVANCE PROCUREMENT INSTRUHENTATION SUBTOTAL 5D3 AOVANCEO PROCUREMENT

504A TANK 109

SOGB TANK 102

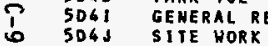

SUBTOTAL 5D4 CONSTRUCTION FORCES

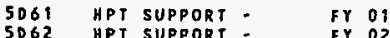

SUBTOTAL 506 HPT SUPPORT AY

SUBTOTAL 5O AY IANK FARM

5EI1 TITLE II - AZ FARM

5EI2 DISE $35-65$ SUPPORT ACTIVITIES

SUBTOTAL 5ET TITLE II-AZ

SE21 TITLE IIS AZ

SUBTOTAL $5 E Z$ TITLE III - AZ

SE3A AOVANCE PROCUREMENT INSTRUMENTATION

SUBTOTAL SE3 ADVANCE PROCUREMENT
* * IEST - INTERACTIVE ESTIMATING * *

TANK FARM RESTORATIOH AHD SAFE OPERATIONS

W - 3 T DOE_ROZ - WORK BREAKDOHH STRUCTURE SUMMARY
PAGE 9 OF 84

OATE $04 / 23 / 96$

BY TLHROP DKH JJM

\begin{tabular}{|c|c|c|c|c|c|c|c|c|}
\hline $\begin{array}{l}\text { ESTIHATE } \\
\text { SUBTOTAL } \\
=======\end{array}$ & $\begin{array}{l}\text { ONSIJE } \\
\text { INDIRECIS } \\
=\geq=\geq=\equiv=\equiv\end{array}$ & $\begin{array}{c}\text { SUB } \\
\text { TOT } A \mathrm{~L} \\
========\end{array}$ & $\Rightarrow=\underset{x}{E S C A}$ & $\begin{array}{l}\text { LATION } \\
\text { TOTAL } \\
=====x=*=\end{array}$ & $\begin{array}{l}\text { SUB } \\
\text { TOTAL } \\
=x=\approx==a z=\approx\end{array}$ & $\begin{array}{c}\text { CONTt } \\
x \\
\Rightarrow= \pm= \pm x\end{array}$ & $\begin{array}{l}\text { NGENCY } \\
\text { TOTAL } \\
===a==x==\end{array}$ & $\begin{array}{c}\text { TOTAL } \\
\text { DOLLARS } \\
=x====\pi=x=\end{array}$ \\
\hline 1109078 & 0 & 1109078 & 15.40 & 170797 & 1279875 & 20 & 255873 & 1535853 \\
\hline 1109078 & 0 & 1109078 & 15.40 & 170797 & 1279875 & 20 & 255973 & 1535853 \\
\hline 275594 & 0 & 275594 & 13.63 & 37012 & 312606 & 25 & 78152 & 390758 \\
\hline 275594 & 0 & 275594 & 13.43 & 37012 & 312606 & 25 & 78152 & 390758 \\
\hline $\begin{array}{r}1525387 \\
1468392 \\
638032 \\
2682461\end{array}$ & $\begin{array}{l}0 \\
0 \\
0 \\
0\end{array}$ & $\begin{array}{r}1525387 \\
1468392 \\
638032 \\
2682461\end{array}$ & $\begin{array}{l}16.83 \\
16.83 \\
16.83 \\
16.83\end{array}$ & $\begin{array}{l}256719 \\
247129 \\
107381 \\
451459\end{array}$ & $\begin{array}{r}1782106 \\
1715521 \\
745413 \\
3133920\end{array}$ & $\begin{array}{l}30 \\
30 \\
35 \\
34\end{array}$ & $\begin{array}{r}534635 \\
514659 \\
260895 \\
1067968\end{array}$ & $\begin{array}{l}2316750 \\
2230187 \\
1006307 \\
4201887\end{array}$ \\
\hline 6314272 & 0 & 6316272 & 16.83 & 1062688 & 7376960 & 32 & 2378157 & 9755131 \\
\hline $\begin{array}{r}43198 \\
129593\end{array}$ & $\begin{array}{l}0 \\
0\end{array}$ & $\begin{array}{r}43198 \\
129593\end{array}$ & $\begin{array}{l}12.99 \\
16.04\end{array}$ & $\begin{array}{r}5611 \\
20787\end{array}$ & $\begin{array}{r}48809 \\
150380\end{array}$ & $\begin{array}{l}10 \\
10\end{array}$ & $\begin{array}{r}4889 \\
15038\end{array}$ & $\begin{array}{r}53690 \\
165418\end{array}$ \\
\hline 172799 & 0 & 172791 & 15.28 & 26398 & 199189 & 10 & 19919 & 219108 \\
\hline 10212658 & 0 & 10212658 & 15.52 & 1585062 & 11797720 & 28 & 3258018 & 15055760 \\
\hline $\begin{array}{r}1538459 \\
845453\end{array}$ & $\begin{array}{l}0 \\
0\end{array}$ & $\begin{array}{r}1538459 \\
845453\end{array}$ & $\begin{array}{l}12.31 \\
12.31\end{array}$ & $\begin{array}{l}189382 \\
104076\end{array}$ & $\begin{array}{r}1727849 \\
949529\end{array}$ & $\begin{array}{l}20 \\
20\end{array}$ & $\begin{array}{l}345568 \\
189906\end{array}$ & $\begin{array}{l}2073412 \\
1139434\end{array}$ \\
\hline 2383912 & 0 & 2383912 & 12.31 & 293458 & 2677370 & 20 & 535474 & 3212846 \\
\hline 1117151 & 0 & 1117151 & 15.40 & 172039 & 1289190 & 20 & 257838 & 1547029 \\
\hline 1117151 & 0 & 1117151 & 15.40 & 172039 & 1289190 & 20 & 257838 & 1547029 \\
\hline 263354 & 0 & 263354 & 13.99 & 36843 & 300197 & 25 & 75049 & 375247 \\
\hline 263354 & 0 & 263354 & 13.99 & 36843 & 300197 & 25 & 75049 & 375247 \\
\hline
\end{tabular}


KAISER ENGINEERS HANFORD WESTIHGHOUSE HANFORO COMPAHY

JOB HO. H314BAC2

\section{HBS DESCRIPTION}

\section{SEMA TANK 101 \\ SE4B TANK 102 \\ SE 4 I GENERAL REQUIREMEHTS \\ SITE WORK \\ SE4H SLUICE PIT 028}

SUBTOTAL SE 4 CONSTRUCTION FORCES

$\begin{array}{lll}\text { 5E61 } & \text { HPT SUPPORT - } & \text { FY } 01 \\ \text { SE } & \text { HPT SUPPORT } & \text { FY } 02\end{array}$

SUBTOTAL $5 E 6$ HPT SUPPORT AZ

SUBTOTAL 5E AZ TANK FARK

5FII TITLE II - SY FARM

SFI2 DISC 35-65 SUPPORT ACTIVITIES

SUBTOTAL 5FI TITLE II - SY FARM

SF21 IITLE III SY

SUBTOTAL SF2 TITLE II - SY FARM

SF3A ADVANCE PROCUREMENT INSTRUMENTATIOH

SF3B ADVANCE PROCUREMENT INSTRUMEHTATION

SF3C ADVANCE PROCUREMENT INSTRUMEHTATION

SUBTOTAL 5F3 ADVAHCE PROCUREMENT

SF4A TANK 101

5F4B TANK 102

SF4C TANK 103

5F4 I GENERAL REOUIREMENTS
* * IEST * INTERACTIVE ESTIMATING *

TANK FARM RESTORATION AND SAFE OPERATIONS

$H=3,4$ CONCEPTUAL ESTIMATE REV. DOE_ROZ - HORK BREAKDOHH STRUCTURE SUMMARY
PAGE 10 OF 84

DATE 0412319614.56 .23

BY TLH RDP OKH JUM

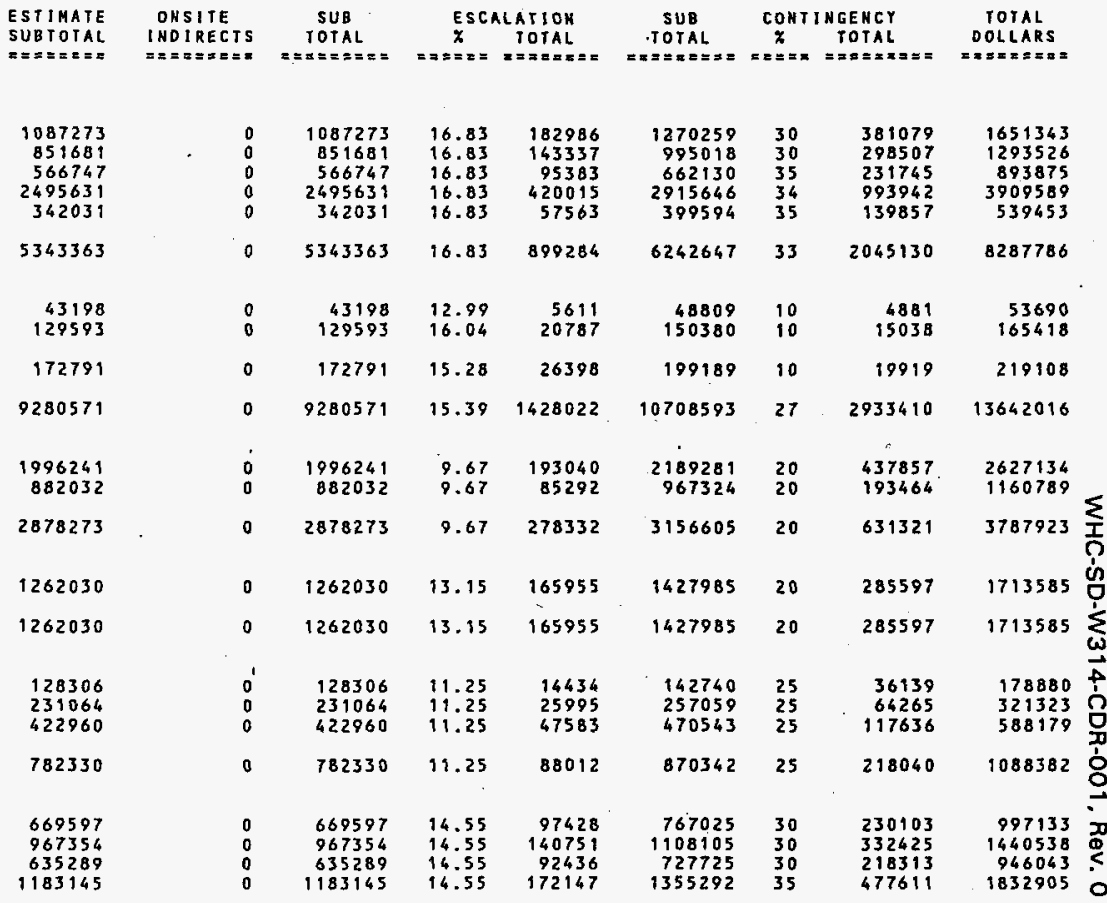


KAISER ENGIHEERS HANFORD

WESTINGHOUSE. HANFORO COMPAKY

JOS NO. W314BAC?

\section{WES DESCRIPTION}

\section{$5 F 4 \mathrm{~J}$ SITE WORK}

SF4K VALVE PIT FY-

SF4L, VALVE PIT SY-B

SUBTOTAL 5FG COHSTRUCTION FORCES

5F61 HPT SUPPORT: $\quad F Y 00$

$\begin{array}{lll}5 F 62 & \text { HPT SUPPORT: } & \text { FY OO } \\ 5 F 63 & \text { HPT SUPPORT } & \text { FY }\end{array}$

SUBTOTAL $5 F G$ HPT SUPPORT SY

\begin{abstract}
SUBTOTAL SF SY TANK FARM
\end{abstract}
SUBTOTAL 5 DOUBLE SHELL TANKS

6A11 TITLE II - 244-A DCRT

6AIZ DISC 35.65 SUPPORT ACTIVITIES

SUBTOTAL 6AT TITLE II - 244-A OCRT

6A21 244-A DCRT-A \& SST SUPPPORT

SUBTOIAL GAR TITLE III - 244-A DCRT

GA3A ADVANCE PROCUREMENT INSTRUMEHTATCOH GA3B ADVANCE PROCUREMENT VENT SYSTEM

SUBTOTAL GA3 PROCUREMENT

GA4A GENERAL REQUIREMENTS

GA4B 24G-A DERT

GAGC 242-A BLDG.

GA4D SITE WORK

SUBTOTAL GAL CONSTRUCTION FORCES
\#* IEST - INTERACTIVE ESTIMATING **

TANK FARM RESTORATION AHD SAFE OPERATIONS H: 3,4 CONCEPTUAL ESTIMATE REV. DOE_ROZ - WORK BREAKOOWN STRUCTURE SUMKARY

ESTIMATE SUBTOTAL
$======$ ONSITE $=====\approx=\pi$

ESCALATIOH

2977063
385757

385757
396403

7214608

17279
259185

$\begin{array}{r}64820 \\ \hline\end{array}$

341284

12478525

94910319

1437084

1835970

711971

711971

187740
136986

324726

1115220

959020

16303
62083

98401

2251027
PAGE It OF 84

$3198 \quad 14: 56: 23$

BY TLWRDP OKH JJM TOTAL

$==x==x==x=x=$

SUB

CONTINGEHCY TOTAL

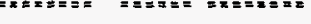
TOTAL
$=\geq= \pm=x$ 385757
396403 $\begin{array}{rr}14.55 & 433162 \\ 14.55 & 56127 \\ 14.55 & 57676\end{array}$

7214608

$14.55 \quad 1049727$ 441884
454079

3
3
3

1144505

154660 158928

826433533

2716545

\section{259185}

$10.02 \quad 1731$ 259185
64820

12.99
16.04

33668

19010
292853
75217

10
10
10

1901
29285

29285
7522

38708

$13.42 \quad 45790$

387080

10

3890211

$12478525 \quad 13.04 \quad 1627822$

14106347

$16.74 \quad 15751889$

109862208

27

29479746

\section{4}

$8.66 \quad 12445$

156953

56953

20

312309

108418

108418

1935970

8.66

167655

$2103625 \quad 20$

157660

791971

90.72

76324

$788295 \quad 20$

157660

71197

10.72

76324

$788295 \quad 20$

157660

\section{0}

$9.67 \quad 18154$

9.67

13247

205894

150233

$356127 \quad 2$

5167
37558

324726

9.67

31401

\section{0}

959020
16303

6208

11.78$$
\text { 11 }
$$

2251027
11.78
131374
112973
1920
7315
7315
11591

124659
107199

18223

69398

109992

$11.78 \quad 265173$

2516200
89032

32998

TOTAL

6554728

596544

613007

10980898

20911 322138
82739

425788

17996576

139341944

1873845

650509

2524354

945954

945954

257368

257368
187791

445159

1676320

1354963

23324

87050
142990

32846470 
KAISER EMGINEERS HANFORD HESI INGHOUSE HANFORD COMPAHY JOB HO. H314BAC2

WBS DESCRIPTION

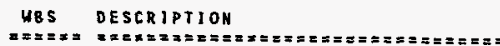

6A61 HPT SUPPORT: FY OO

SUBTOTAL $6 A 6$ HPT SUPPORT $244-A$

SUBTOTAL GA 244.A DCRT

6811 TITLE II- $244-5$ DCRT

6812 DISE $35-65$ SUPPORT ACTIVITIES

SUBTOTAL 6BI TITLE II 244-S OCRT

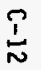

6821244.5 DCRT-S

SUBTOTAL 6BZ TITLE III - 244.5 DCRT

\begin{abstract}
GB3A IHSTRUHENTATION
GB3B VEHTILATION SYSTEA

SUBTOTAL 683 PROCUREMENT
\end{abstract}

GBGA GEMERAL REQUIREMENTS

6B4B 244-5 DCRT

6BGI. OFFICIAL ACCEPTAHCE OF COHST. SUBTOTAL $6 B 4$ CONSTRUCTION FOREES

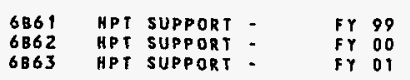

6863 HPI SUPPORT. FYOT

SUBTOTAL 686 HPI SUPPORT $244-5$

SUBTOTAL 6B 244-S OCRT
* IEST - IRTERACTIVE ESIIMATING *

TANK FARM RESTORATIOH AND SAFE OPERATIONS $K$
- 314 CONCEPTUAL ESTIMATE REV.

\begin{tabular}{|c|c|c|c|}
\hline $\begin{array}{l}\text { EST IHATE } \\
\text { SUBTOTAL } \\
=======\end{array}$ & $\begin{array}{l}\text { ONSITE } \\
\text { INDIRECTS } \\
==x=E===\end{array}$ & $\begin{array}{c}\text { SUB } \\
\text { TOTAL } \\
=x===\equiv= \pm=\end{array}$ & 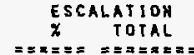 \\
\hline
\end{tabular}

SU6

PAGE 12 OF 84

OATE 04/23/96 14:56:24

BY TLH RDP DKH JJH

TOTAL

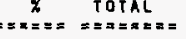

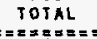

a TOTAL

TOTAL

DOLLARS

\begin{tabular}{|c|c|c|c|c|c|c|c|c|}
\hline $\begin{array}{l}86395 \\
21622\end{array}$ & $\begin{array}{l}0 \\
0\end{array}$ & $\begin{array}{l}86395 \\
21622\end{array}$ & $\begin{array}{l}10.02 \\
12.90\end{array}$ & $\begin{array}{l}8657 \\
2809\end{array}$ & $\begin{array}{l}95052 \\
24431\end{array}$ & $\begin{array}{l}10 \\
10\end{array}$ & $\begin{array}{l}9505 \\
2443\end{array}$ & $\begin{array}{r}104557 \\
26874\end{array}$ \\
\hline 108017 & 0 & 108017 & 10.62 & 11466 & 119483 & 10 & 11948 & 131431 \\
\hline 5331711 & 0 & 5331711 & 10.35 & 552019 & 5883730 & 25 & 1447818 & 7331545 \\
\hline $\begin{array}{r}1322890 \\
440034\end{array}$ & $\begin{array}{l}0 \\
0\end{array}$ & $\begin{array}{r}1322890 \\
440034\end{array}$ & $\begin{array}{l}7.23 \\
7.23\end{array}$ & $\begin{array}{l}95643 \\
31814\end{array}$ & $\begin{array}{r}1418533 \\
471848\end{array}$ & $\begin{array}{l}20 \\
20\end{array}$ & $\begin{array}{r}283707 \\
94369\end{array}$ & $\begin{array}{r}1702237 \\
566218\end{array}$ \\
\hline 1762924 & 0 & 1762924 & 7.23 & 127457 & 1890381 & 20 & 378076 & 2268455 \\
\hline 862125 & 0 & 862125 & 9.15 & 78884 & 941009 & 20 & 188201 & 1129212 \\
\hline 862125 & 0 & 862125 & 9.15 & 78884 & 941009 & 20 & 188201 & 1129212 \\
\hline $\begin{array}{l}265322 \\
126106\end{array}$ & $\begin{array}{l}0 \\
0\end{array}$ & $\begin{array}{l}265322 \\
126106\end{array}$ & $\begin{array}{l}\text { B. } 18 \\
\text { B. } 18\end{array}$ & $\begin{array}{l}21703 \\
10315\end{array}$ & $\begin{array}{l}287025 \\
136421\end{array}$ & $\begin{array}{l}25 \\
25\end{array}$ & $\begin{array}{l}71756 \\
34105\end{array}$ & $\begin{array}{l}358782 \\
170527\end{array}$ \\
\hline 391428 & 0 & 391428 & 8.18 & 32018 & 423446 & 25 & 105861 & 529309 \\
\hline $\begin{array}{r}1028268 \\
943671 \\
98401\end{array}$ & $\begin{array}{r}0 \\
18830 \\
0\end{array}$ & $\begin{array}{r}1028268 \\
962501 \\
98401\end{array}$ & $\begin{array}{l}9.67 \\
9.67 \\
9.67\end{array}$ & $\begin{array}{r}99433 \\
93076 \\
9516\end{array}$ & $\begin{array}{r}1127701 \\
1055577 \\
107917\end{array}$ & $\begin{array}{l}34 \\
26 \\
30\end{array}$ & $\begin{array}{r}388240 \\
273504 \\
32375\end{array}$ & $\begin{array}{r}1515944 \\
1329083 \\
140292\end{array}$ \\
\hline 2070340 & 18830 & 2089170 & 9.67 & 202025 & 2291195 & 30 & 694119 & 2885319 \\
\hline $\begin{array}{r}21622 \\
86395 \\
5417\end{array}$ & $\begin{array}{l}0 \\
0 \\
0\end{array}$ & $\begin{array}{r}21622 \\
86395 \\
5417\end{array}$ & $\begin{array}{r}7.13 \\
10.02 \\
13.00\end{array}$ & $\begin{array}{r}1542 \\
8657 \\
704\end{array}$ & $\begin{array}{r}23164 \\
95052 \\
6121 .\end{array}$ & $\begin{array}{l}10 \\
10 \\
10\end{array}$ & $\begin{array}{r}2316 \\
9505 \\
612\end{array}$ & $\begin{array}{r}25480 \\
104557 \\
6733\end{array}$ \\
\hline 113434 & 0 & 113434 & 9.61 & 10903 & 124337 & 10 & 12433 & 136770 \\
\hline 5200251 & 18830 & 5219081 & 8.65 & 451287 & 5670368 & 24 & 1378690 & 7049065 \\
\hline
\end{tabular}


XAISER ENGINEERS HANFORO

WESTINGHOUSE HANFORD COMPAHY

JOB HO. W31GBACZ

WBS OESTRIPTIOH

SUBTOTAL 601 TITLE II- SST

6021 TITLE III ENG. DURING CONST.

SUBTOTAL 602 TITLE III SST - EHG. DURING

SD4A GENERAL REQUIREMENTS

SUBTOTAL 604 CONSTRUCTION FORCES

O 6D5A GENERAL REQUIREMENTS

D 605B AFARH

6DSC AX FARH

605D B FARH

605E $8 X$ FARH

6056 G

GOSN T FARH

GDSI TX FARM

GDSJ TY FARH

6D5K S FARM

GDSL SY FARM

605H U FARM

SUBTOTAL 605 FIXEO PRICE CONSTRUCTIOH

$\begin{array}{lll}\text { ODO } & \text { HPT SUPPORT } & \text { FY } 99 \\ 6062 & \text { HPT SUPPORT } & F Y 00\end{array}$

SUBTOTAL 606 HPT SUPPORT SST

SUBTOIAL BO SST SUPPORT SYSTEMS

SUBTOJAL 6

INTERFARM SUPPORT SYSTEMS
* IEST - INTERACTIVE ESTIMATING * *

TANX FARM RESTORATION AHD SAFE OPERATIONS DOE_RO2 - HORK BREAXDOWN STRUCTURE SUMKARY
PAGE 14 OF 84

DATE $04 / 23 / 96 \quad 14: 56: 26$

BY : TLH RDP OKH JJH

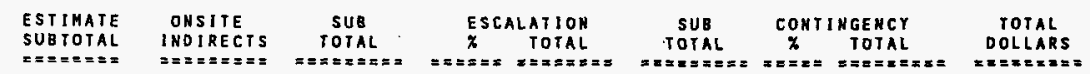

\begin{tabular}{|c|c|c|c|c|c|c|c|c|}
\hline 799433 & 0 & 799433 & 6.06 & 48448 & 847881 & 20 & 169575 & 1017454 \\
\hline 702620 & 0 & 702620 & 9.41 & 66117 & 768737 & 20 & 153747 & 922484 \\
\hline 702620 & 0 & 702620 & 9.41 & 66117 & 768737 & 20 & 153747 & 922484 \\
\hline 39785 & 0 & 38785 & 9.67 & 3847 & 43632 & 30 & 13090 & 56722 \\
\hline 39785 & 0 & 39785 & 9.67 & 3847 & 43632 & 30 & 13090 & 56722 \\
\hline $\begin{array}{l}68223 \\
109440 \\
109447 \\
109447 \\
109447 \\
109447 \\
120531 \\
109447 \\
147947 \\
109447 \\
109447 \\
109447 \\
109447\end{array}$ & $\begin{array}{r}8404 \\
37545 \\
22546 \\
22546 \\
22546 \\
22546 \\
24830 \\
22546 \\
30477 \\
22546 \\
22546 \\
22546 \\
22546\end{array}$ & $\begin{array}{r}76627 \\
146985 \\
131993 \\
131993 \\
131993 \\
131993 \\
145361 \\
131993 \\
178424 \\
131993 \\
131993 \\
131993 \\
131993\end{array}$ & $\begin{array}{l}9.40 \\
9.40 \\
9.40 \\
9.40 \\
9.40 \\
9.40 \\
9.40 \\
9.40 \\
9.40 \\
9.40 \\
9.40 \\
9.40 \\
9.40\end{array}$ & $\begin{array}{r}7203 \\
13816 \\
12407 \\
12407 \\
12407 \\
12407 \\
13664 \\
12407 \\
16772 \\
12407 \\
12407 \\
12407 \\
12407\end{array}$ & $\begin{array}{l}83830 \\
160802 \\
144401 \\
144401 \\
144401 \\
144401 \\
159024 \\
144401 \\
195197 \\
144401 \\
144401 \\
144401 \\
144401\end{array}$ & $\begin{array}{l}20 \\
20 \\
21 \\
21 \\
21 \\
21 \\
21 \\
21 \\
22 \\
21 \\
21 \\
21 \\
21\end{array}$ & $\begin{array}{l}17075 \\
32768 \\
30309 \\
30309 \\
30309 \\
30309 \\
33229 \\
30309 \\
43008 \\
30309 \\
30309 \\
30309 \\
30309\end{array}$ & $\begin{array}{l}100908 \\
193570 \\
174709 \\
174709 \\
174709 \\
174709 \\
192253 \\
174709 \\
238203 \\
174709 \\
174709 \\
174709 \\
174709\end{array}$ \\
\hline 1431164 & 304170 & 1733334 & 9.40 & 163118 & 1898462 & 21 & 398861 & 2297313 \\
\hline $\begin{array}{l}172790 \\
172790\end{array}$ & $\begin{array}{l}0 \\
0\end{array}$ & $\begin{array}{l}172790 \\
172790\end{array}$ & $\begin{array}{r}7.13 \\
10.02\end{array}$ & $\begin{array}{l}12320 \\
17314\end{array}$ & $\begin{array}{l}185190 \\
190104\end{array}$ & $\begin{array}{l}10 \\
10\end{array}$ & $\begin{array}{l}18511 \\
19010\end{array}$ & $\begin{array}{l}203621 \\
209114\end{array}$ \\
\hline 345580 & 0 & 345580 & 8.58 & 29634 & 375294 & 10 & 37521 & 412735 \\
\hline 3318582 & 304170 & 3622752 & 8.59 & 311164 & 3933926 & 20 & 772794 & 4706708 \\
\hline 190011 & 323000 & 33513011 & 9.98 & 3343523 & 36856544 & 27 & 10072800 & 46929333 \\
\hline
\end{tabular}

33190011

$323000 \quad 33513011$

9.983343523 
KAISER EHGINEERS HANFORD

WESTINGHOUSE HAMFORD COMPAHY

JOB NO. H314BAC2

HES DESCRIPTION

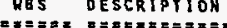

PROJECT TOTAL
* IEST - INTERACTIVE ESTIMATING ** TANK FARM RESTORATION AND SAFE OPERATIOHS DOE : 3 I 4 COR CONCEPTUAL ESTIMATE REV.
PAGE 14A OF 84

DATE 04/23/96 14:56:24
TLW ROP DXH JJI

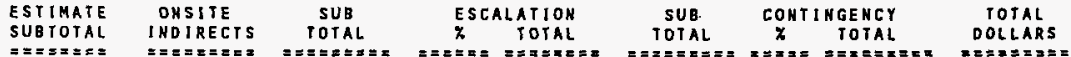

SUBTOTAL

$==\Sigma= \pm=x=2$ 
KAISER EHGIHEERS HAKFORO WESTIHGHOUSE HANFORD COMPANY JOB NO. HSTLOBAC2

FILE NO. H314BAC2
* * IEST - InIERACTIVE ESTIRATINg * * IANK FARM RESTORATION AND SAFE OPERATIONS H. 314 CONCEPTUAL ESTIMATE DOE_RO3. ESTIMATE BASIS SHEET
PAGE 15 OF
DATE $4 / 23 / 96$

BY: DTLH ORDP ODKH JJM

1. DOCUNERTS AND ORAHIHGS

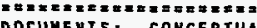

DOCUMENTS: CONCEPTUAL DESIGH REPORT, TAHK FARM RESTORATION AHD SAFE OPERATIONS, DATED (MARCH/96) AND SKETCHES

AS PROVIDED BY THE EHGINEER. ORCR COMMENTS BY OHACTEC.

2. MATERIAL PRICES

UHIT COSIS REPRESENT CUREENT PRICES FOR SPECIFIED MATERIAL. VENDOR INFORMATIOH HAS OBTAIHED FOR THE FOLLOHING ITEMS

OAMEROH PRODUCTS - PIT COATING

OSCS - TYPE A BURIAL BOXES

AIR CONTROL, DIKC. - QHEPA FILTER HOUSINGS

UNIT PROCESS CO. - ISOLATION BUTTERFLY VALYES

LABOR RAIES

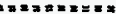

A.) IICF-OKH HOURLY RATES ARE BASED ON THE 1996 FISCAL YEAR BUOGET LIQUIDATION RATES AS ISSUED BY XEH FIHAMCE (EFFECTIVE 03-18-96). SEE ALSO THE OFY 1996 PLANHING RATES * (REPORT ABGHB7012).

B.) BASE CRAFT RATES ARE AS ISSUED BY KEH FINANCE (EFFECTIVE 10-01-95). RATES INCLUDE FRINGE BENEFITS, LABOR IHSURANCE, TAXES

DEPARTMENTAL OVERHEADS, GRA AND ASUS, AND TRAVEL.

C.) UHC HOURLY RATES

4. GEMERAL REQUIREMENTS/TECHNICAL SERVICES/OVERHEADS

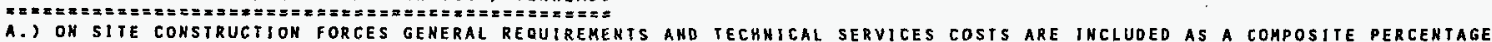

QASED ON THE ICF-KH ESTIMATING FACIORS FOUND IN SECTION 2 OF THE BUDGET GUIDELINE HANDBOOK (BGHB) LOCATEO ON HAHEORD SOFT

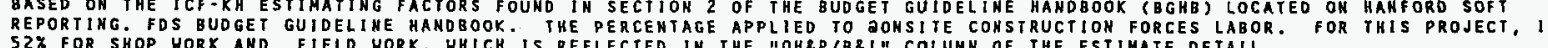

B.) ONSITE COHTRACT ADMINISTRATION AHD COHSTRUCTION MANAGEMENT COSTS, ASSOCIATED WITH BHE OVERALL MAHAGERENT OF THE FIXEO PRICE CONTRACTS, ARE INCLUDEO AS A CONPOSITE PERCENIAGE AND LUHP SUM ALLOLANCE )FOR BID PACKAGE PREP) BASED ON THE ESTIMATING FACTOR/BILLING SCHEDULE. THE TOTAL COMPOSITE PERCENTAGE AND LUMP SUM ALLOHANCE ARE APPLIED AGAINST THE TOTAL FIXED PRICE CONTRACT AMOUNI HHICH IS REFLECIED DN THE KEH SUMMARY REPORT DOE ROT, IHCLUDED HITH THIS ESTIMATE, (FIHAL ESTIMATES MAY BE PARTIALLY MANLOADED AND INCLUDED WITHIN THE ESIIMATE DETAIL).

C.) FIXED PRICE CONTRACTOR OVERHEAD, PROFIT, BOND AND INSURANCE COSTS HAVE BEEN APPLIED AT THE FOLLOHIHG PERCEHTAGES

ANO ARE REFLECTED IH THE "OH\&P/B\&I" COLUMN OF THE ESTIMATE DETALL

LABOR - 30\%, MATERIAL - 30\%, EQUIPMENT USE - 10\%, EQUIPRENT - O\% AND SUBCONTRACTS - 10X

5. ESCALATION

ESCALATION PERGENTAgES HERE CALCULATEO FROM THE AUGUSt, 1995 UPDATE OF THE ECONOMIC ESCALATION PRICE CKANGE IMDICES FOR DOE CONSIRUCIION PROJECTS AS PUBLISHED BY THE "OFFICE OF INFRASTRUCTURE ACOUISITION" EM-SO.

6. ROUNDING

U.S. DEPARTHENT DF ENERGY - DOE ORDER 5100.4 PAGE I-32 SUBPARAGRAPH (K), REOUIRES ROUHDING OF ALL GENERAL PLAMT PROJECIS (DGPP'S) AND LINE ITEM (LI) COSIESTIMATES. REFERENCE: DOE S100.4, FIGURE I-11, DATED 10-31-B4. 
KAISER EHGI HEERS HAHFORD

WESTIHGHOUSE HAHFORO COMPANY

JOB NO. U314BACI

FILE NO. H314BAC1

\section{REMARKS}

$=\pi \mathrm{x}=\mathrm{Ex}=$

1. METHOD OF PERFORMANCE:

A. DESIGN BY ONSITE AIE.

B. CONSTRUCTION INSIDE OF THE TANK FARM FENCES IS BY THE ONSITE CONSTRUCTION FORCES.

C. CONSTRUCTION DUTSIOE OF THE TANK FARM FENCES IS BY FIXED PRICE CONIRACT.

D. PROJECT MANAGEHEKT IS BY THE OPERATING CONTRACTOR.

2. OTHER PROJECT COSTS IS PERFORMEO BY THE OPERATING CONTRACTOR.

. RAOLATION ALLOWANCES OF $159 \mathrm{mr}$ (SAME BASIS AS H-21

OF PITS FOR REMOVAL AMD REPLACEMENT OF JUMPERS ONLY. QURHOUT IS ONLY INCLUDEO FOR PIT MODIFICATIOKS.

3. CRANE ALLOWANCES ARE FOR ZOEA $30 T$ TROVES AHD IEA TMANITOWOC $100 T$

4. NEW JUKPER ALLOWANCES: A.) GEA INSIDE DESIGHATED VALVE PIIS, B.) 2EA INSIDE DESIGMATEO PUMP PITS.

BURIAL FOR EXISTIHG JUMPERS IS FBR THE REPLACEMENTS AND THOSE LISTED BY ENGINEERING

5. NEH COVER BLOCX COSTS ARE BASED UPON PROJECT H-151, TARK 101-AZ HASTE RETRIEVAL SYSTEM.

6. PROJECTS H-211 AND W-030 "LESSONS LEARNED" WERE INCORPORATED INTO THE COSTESTIMATE FOR JUMPERS AND EXCAVATION.

7. PER UHC OJRECTIONS, THIS COST ESTIMATE DOES MOT INCLUDE MASK WORK ON ALL FIELD WELDS (PER I/J1/QG HEETING).

B. SEALING OF PITS IS INCLUDED FOR THOSE THAT NERE OPEHEO.

9. FRESH ALR SUPPORT IS SHOUN SEPARAIELY FROM HASK YORK.

I 10. TRANSFER PIPIHG BETHEEN TAMK FARMS IS BASED UPOH THE YORK BEIHG PERFORMED BY COHSTRUCTION FORCES.

o

11. VERIFICATION OF EXISTIHG IHSTRUMENTATION OPERATION, IN ALL FARMS IS ASSUMED TO BE PERFORHED BY THE OPERATING COHTRACTOR. 12. COVER BLOCX BURIAL INCLUDES URAPPIXG IN PIASTIC, IN ONE PIECE, AHO IRANSPORTATION TO THE BURIAL GROUHOS. IT WAS ASSUMED THAT BURIAL IN BOXES IS NOT NECESSARY

13. LEAK DETECTOR INSTALLATION ASSUMES THAT EACH PIT HILL ALREADY OE OPEHED FOR OTHER HORK. IN OTHER WORDS COVER BLOCK REMOVAL IS PROVIOED NITH PIT MODSFBCATIONS SUCH AS HEH COATINGS AND JUMPER REPLACEMENTS, ETC..

14. ASBESTOS ABATEMEHT OH PIPIMG IIE-IHS IS ASSUMEO TO NOT BE A PROBLEM.

- REHORK OF EXISTING PIPING, UHOERGROUND UTILITIES, ETC. FOR EASE OF PIPE AND CONOUIT INSTALLATION IS RDT INCLUDEO IN THE COST ESTIMATE. AN ALLOWANCE FOR THIS IS RAS BEEN ADORESSED IN THE CONTINGENCY AHALYSIS.

16. JUHPER CUTUP HILL BE PERFORMEO BY USING AN EXISTIUG ON SITE MECHANICAL SHEAR.

17. SPECIAL HORK PROCEDURE (SHP) MARKUP FOR THIS PROJECT HAS BEEH APPLIED AT $40 X$. THIS IS USEB TO COMPENSATE FOR PRODUCTIVITY LOST DUE TO HORKING IN THE TAHK FARM. PRODUCTIVITY IS LOST FOR SAFETY MEETINGS, DPREJOB REVIEH, DRESS, SURVEY OUT, TRAKSPORT TO AHD FROM FARM, AND LOADING OF TOOLS FOR TRANSPORT. ALONG WITH THESE ACTIVITIES. THERE ARE OTHER DELAYS THAT ARE MOT ACCOUNTED FOR BY THIS PERCENTAGE: LATE ARRIVALS OF OHPT'S AND OPERATORS, ACCESS THROUGH IHE DWRAM SYSTEMS, LARGE CREN (CHANGE TRAILER LIMITATIONS), CONFLICTS HITH WHC OPERATIONS, INITIAL PREJOB BRIEFINGS HHICH CAN TAKE UP TO OHE HOUR, REASSIGHMENT OF PERSONNEL WHICH WILL CAUSE A REVIEN OF IHITIAL PREJOB BRIEFING AND QUESTIONS, LACK OF TRANSPORTATIOH, CHANGES IH FARM CONDITIONS, SAFETY CONCERNS AND HEATHER. THESE DELAYS OR IMPACTS HAVE BEEN AOQRESSED THROUGH COHTINGENCY APPLICATION.

18. ASSUME ALL WORK WILL BE DONE DURSNG THE NORMAL HORK DAY, $7: 30 A M-4: 30 P M$, THERE ARE NO ALLOUAMCES MAOE FOR SHIFT WORK OR OVERTIHE.

19. H314BAC2, REV. 1 INCORPORATES THE RCR ESTIMATING COMMENTS THAT HAS PROVIOEO BY MACTEC. 
KAISER ENGINEERS HAMFORD

WESTI HGHOUSE HAHFORD CONPANY

JOB HO. US14BAC2

$\cos T$

CODE / WB S

DESCRIPIIOH

O IO ENGINEERIKG - TITLE I

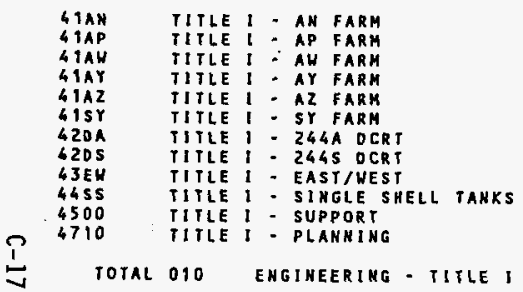

020 EHGIHEERING - TITLE II

\begin{tabular}{|c|c|c|c|}
\hline $\begin{array}{l}5 A 11 \\
5 A 12 \\
5 B 11 \\
5 B 12 \\
5 C 11 \\
5 C 12 \\
5011 \\
5012 \\
5 E 11 \\
5 E 12 \\
5 F 11 \\
5 F 12 \\
6 A 119 \\
6 A 12 \\
6 B 11 \\
6 B 12 \\
6 C 11 \\
6 C 12 \\
6011 \\
6012\end{array}$ & 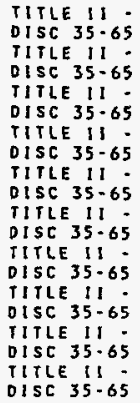 & 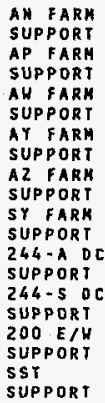 & $\begin{array}{l}\text { ACTIVITIES } \\
\text { ACTIVITIES } \\
\text { ACTIVITIES } \\
\text { ACTIVITIES } \\
\text { ACTIVITIES } \\
\text { ACTIVITIES } \\
\text { ACT } \\
\text { ACTIVITIES } \\
\text { ACTIVITIES } \\
\text { ACTIVITIES }\end{array}$ \\
\hline
\end{tabular}

6012
DISC $35-65$ SUPPORT ACIIVITIES
** IEST - INTERACTIVE ESTIMATIHG ** TAMK FARM QESTORATION AND SAFE OPERATIONS W. 3,4 CONCEPTUAL ESTIMATE REV. DOE_ROL - COST CODE ACCOUHT SUMMARY SUBTOTAL INOIRECT

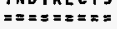

SUB
TOTAL ESCALATION JOTAL TOTAL $=$ PAGE 17 OF 84 BY TLH RDP DKH JJM $=x=x=x==$

I HOENCY

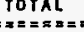

$==\equiv=\Sigma= \pm=$

379273
187687
148321
83586
101538
139864
145457
99218
179284
49867
2537884
1116246

5108225

5168225

2785094

963857

2293977

2398797

1010033

1497662

843261

1538459

845453

1996241

882032

1437084

498886

1322890

440034
2668788

2668788

354475

354475
466958

\begin{abstract}
$=x=x= \pm=2$
\end{abstract}
$=2 x$

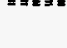

Dotal $==x= \pm x=x=$

379273
187687
148321
83586
101538
139864
145457
99218
179284
49867
2537884
1196246
5168225

3.93
3.93
3.93
3.93
3.93
3.93
3.93
3.93
3.93
3.93
3.49
3.93
3.71

14905

14905
7375

5829

3284

5996

5717

3900

7045
1960

9960
88489

88489
43867

191857

394178
195062
154150
86870
105528
145360
151174
103118
186329
51827
2626373
1160113

2626373
1160113

5360082

15
15
15
15
15
15
15
15
15
15
15
15
15

59126

$23122 . \quad 173323$

13032

15830

21802

22676

22676

27948

0774

393954
174017

806006

99901

121357

167164

173851
118586

214280

3020330

1334131

6164099

2785094

$15.68 \quad 436704$

$963857 \quad 15.88 \quad 151131$

$2293977 \quad 17.12 \quad 392727$

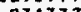

17.12

392727

3221798
1114988

1114988
2686704

1090783

2560628

$6.75 \quad 161911$

12.750878

$1497602 \quad 12.31 \quad 184361$

$043261-12.31-103806$

$\begin{array}{lll}1538459 & 12.31 & 189382\end{array}$

$10452412.39 \quad 104076$

$\begin{array}{lll}882032 & 9.87 & 193040 \\ 1437086 & 8.66 & 85292\end{array}$

$1437086 \quad 8.66 \quad 124452$

$\begin{array}{lll}498886 & 8.66 & 43203\end{array}$

$\begin{array}{rrr}1322890 & 7.23 & 95643 \\ 440034 & 7.23 & 31814\end{array}$

440034

$266878 B$

$6.52 \quad 31814$

174005
55020

843857

444958

6.06

1682023

947067

1727841

949529

2189281

967324

1561536
542089

1418533

471848

471848
2842793

898877

375958

21483
26965

471923

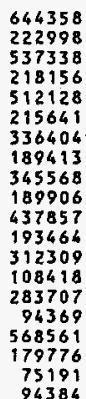

3866157 1337987 3224050 1308937 3072757

1293852

2018430

1136480

2073412

1139434

2627134

1160789

1873845

650509

1702237

566218

3411350

1078651

451146

566308 
KAISER ENGINEERS HAHFORD

WESTINGHOUSE HAHF ORD COMPANY

JOB HO. W314BAC2

\section{$\cos T$}

CODE/WBS

DESCRIPTION

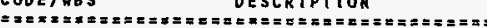

TOTAL D2O ENGIHEERING - TITLE II

O30 engineering - title itI
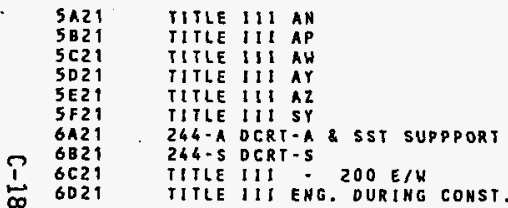

TOTAL 030 ENGIHEERING - TITLE III

\section{PROJECT MANAGEMENT}

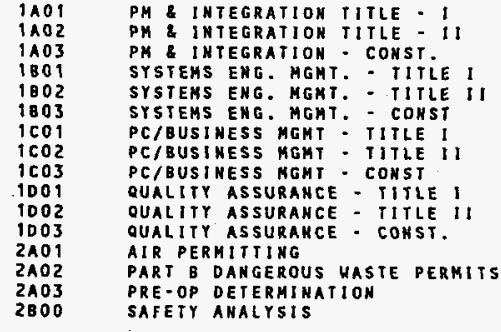

TOTAL OSO PROJECT MANAGEKENT
* * IEST - INTERACTIVE ESTIMATING **

TANK FARM RESTORATION ANO SAFE OPERATIONS

H - 314 CONCEPTUAL ESTIMATE REV.

PAGE 18 OF 84

BY TLW RDP OKH JJM

ESTIMATE

SUBTOIAL

ONSIIE

INOJRECTS

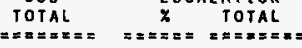

ESCALATION

SUB CONTI HGENCY
$X$ TOTAL

TOTAL

$== \pm=\Sigma=$

0

25997095

$10.78 \quad 2802639$

2879973

5759946

34559683

2429600

1778622

1700770

1109078

1117158

1262030

71197

1333463

702620

13007430

2429600
1778622
1700770
1109078
1117151
1262030
711971
862125
1333663
702620

20.93
22.73
10.72
15.40
15.40
13.15
10.72
9.15
10.72
9.41

508515

404282

182323

172039

165955

76324

78884

142945

2938115
218290

2182904
1883093

1279875

1289190

1427985

788295

941009

1476408

768737

$5.13 \quad 1968181$

14975611

20
20
20
20
20
20
20
20
20
20
20

587625

$36580 \quad 3525739$

$\begin{array}{ll}376620 & 2619482 \\ & 2259713\end{array}$

$255973 \quad 1535853$

$257838 \quad 1547029$

$285597 \quad 1713585$

$157660 \quad 945954$

$188201 \quad 1129212$

$294629 \quad 177103$ ?

13007430

2994470

$179700 B 8$

427746

2239150

2320133

471240

793968

573750

268799

846564

585178

220742

551855

441484

81043

60534

3077
159886

11017149
427746

2239150

2320133

2320133
77240

793968

793968
573750

573750
248799

248799
846564

866564
585178

220742

551855

441484

81043

60534

3077
1151886

2.89

10.43
17.15

17.15
2.67

10.37

21.54

2.67
10.43

21.54

2.94

10.10
20.82
4.31

4.31
13.09

4.32
8.96

11097149

12.27
12375

233582

397838

12563

82369

123560
6633

88288

126069

6490

55726

91928

3493
7926

440121

247273

2717971
483803

483803
876337

697310

25543

93485

711247

227232

607581

533412

84536

6846

3210
55053

103167

1255053

1352140

12369289

10
10
10
10
10
10
10
10
10
10
10
10
10
10
10
10
10

44012
247273
271797
48380
87633
69731
25543
93485
71125
22723
60758
53349
8454
6846
321
125506
236928

484133

27.006

2989769

963971

767042

280975

1028338

782372

249955

668339

586753

92990

75307

1380557

13606221 
KAISER ENGTMEERS HAMFORD HESTINGHOUSE HAHFORD COMPARY JOS NO. H314BACZ

$\cos 1$

COOE/WBS

DE SCRIPI 1 ON

600 UTILITIES

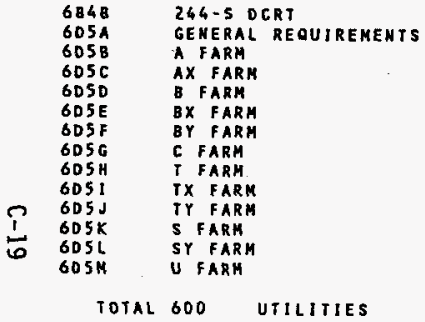

700 SPECIAL EQUIP/PROCESS SYSTEMS

5A3A AOVAHCE PROCUREMENT INSTRUMENTATION 5A3B PRIMARY VENT SYS ADVANCED PRCMT

SA4A TAKK 101

$5 A 4 B$ TANK 102

SA4C IAHK 103

SA4D TANK 104

$5 A 4 E$ TANK 105

$5 A 4 F$ TANK 106

SA46 TANK 107

$5 \wedge$ (

546

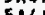

$5 \AA 61$

$5 \wedge 62$

$5 \wedge 63$

GENERAL REC

SITE WORK RUIREMENTS

TAHK 109 .

TANK TOP - VALVE PIT AH-A

TANK 101 - VALVE PIT - AN-

HPT SUPPORT - $\quad$ EY OZ

HPT SUPPORT - $\quad$ FY OS

APY SUPPORT

FY 04

ADVAHCE PROCUREMENT INSIRUMENTATION
PRIMARY VENT SYS ADVANCED PRCMT
* * IEST - INTERACTIVE ESTIMATING * TAMK FARH RESTORATION AMD SAFE OPERATIONS H. 314 CONCEPTUAL ESTIHATE REV.

OOE_RO4: COST CODE ACCOUNT SUMMARY

ESTIMATE SUBTOTAL $== \pm= \pm= \pm$

ONSITE INDIRECTS

SUB
TOTAL $=x==x==x=x$

PAGE 19 OF 84

DATE $04 / 23196 \quad 14: 56: 45$ TLY RDP DKH HOH

40252
40798
109440
109447
109447
109447
109447
120539
109447
109447
109447
109447
109447
109447

1883
840
3754
2254
2254
2254
2254
2483
2254
2256
2254
2254
22546
22546

1405491

\section{2}

\section{2}

146985
131993

131993

131993

131993

145361

131993

131993

131993

131993

131993
131993

1720560

9.67

9.40
9.40

9.40
9.40

9.40

9.40
9.40

9.40
9.40

9.40

9.40
9.40

9.40

9.40
9.40

9.41

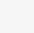

161888

5713

4625
13816

12407

12407
12407

12407

13664

12407

12407

12407

12407

12407
12407

741394

710675

673305

644035

51093

551589

5776

627873

2827376

3500755

589719

606395

64820

259185

259185

1355706
710675
74139

$$
\begin{aligned}
& 741394 \\
& 71067 \\
& 67330
\end{aligned}
$$

710675
673305

644035

551093

521589

550976

627873

644365

2827376

3500755

589719

606395

64820

259185

259185

1355706
710675
$17.41 \quad 129077$

$17.41 \quad 123729$

$22.13 \quad 149004$

$22.13 \quad 142526$

$22.13 \quad 121958$

$22.13 \quad 12206$

$22.13 \quad 12193$

162600

142600

2.13

22.13

22.13

16.04

19.17

22.39

18.86

18.86

625700

774798
130506

134196

10397

49686

58032
255686

134033

64795
53827
160802
144401
144401
144401
144401
159024
144401
144401
144401
144401
144401
144401
1882458

$\begin{array}{rr}12959 & 77754 \\ 8074 & 61902 \\ 32768 & 193570 \\ 30309 & 174709 \\ 30309 & 174709 \\ 30309 & 174709 \\ 30309 & 176709 \\ 33229 & 192253 \\ 30309 & 176709 \\ 30308 & 174709 \\ 30309 & 174709 \\ 30309 & 174709 \\ 30309 & 174709 \\ 30309 & 174709 \\ 390120 & 2272569\end{array}$

87047125

$834604 \quad 25$

82230

78656

673051

673658

672907

766822

786965

3453076

4275473

720225

740591

75217

308871

317217

1611392
844708

217698

208601

246692

235968
201916

202098

201872

23004

236088

1035923

1183499

25020

257732

7522
30887

3172

40284

211177

1088088

1043006

1069001

1022529

874968

875755

874782

996870

4488997

5458968

970425

998322

82739

339758

348938

2014240
1055885 
KAISER EHGINEERS HANFORD

UESTIHGHOUSE HAKFORD COMPANY

JOB ND. W314BACZ

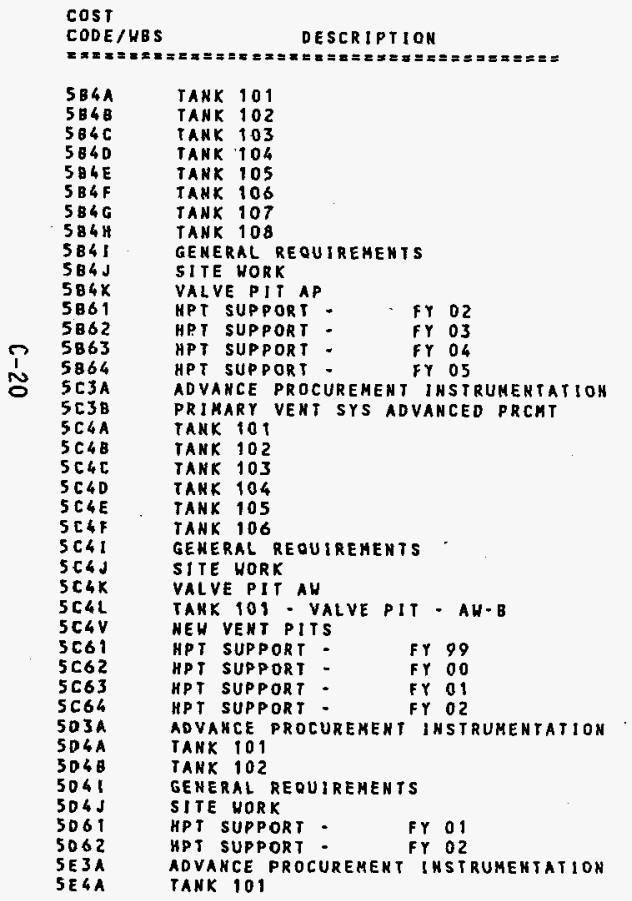

* IEST - Interactive estimating ** TANK FARM RESTORATION AND SAFE OPERATIONS W - 314 CONCEPTUAL ESTIMATE REV. DOE_RO4: COST CODE ACCOUNT SUMMARY REV.

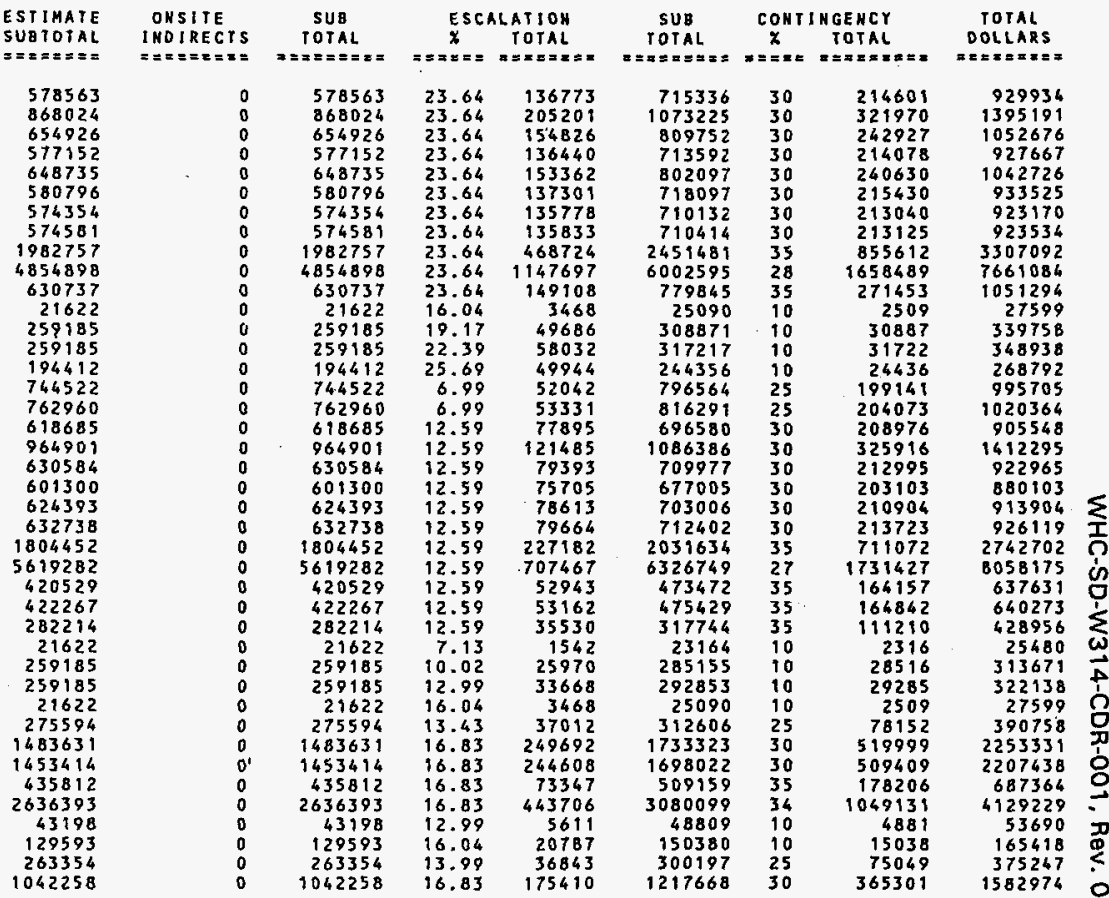

PAGE 20 OF 84 BY TLH ROP OKH JJH DATE O4/23/96 14:56:45 
KAISER ENGINEERS HAHFORD WEST I HGHOUSE HANFORD COMPANY JOB $\mathrm{NO}$. $1314 \mathrm{BAC2}$

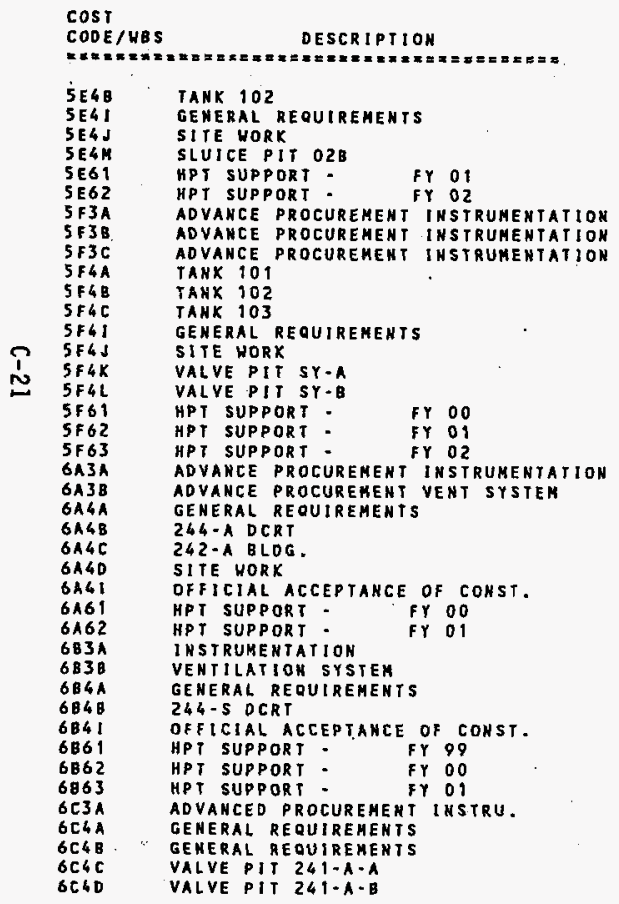

* IEST - INTERACTIVE ESTIMATING * TAHK FARM RESIORATION AHD SAFE OPERATIONS H = 314 COHCEPTUAL ESTIMATE REV. 1 DOE_ROA - COST CODE ACCOUNT SUMMARY

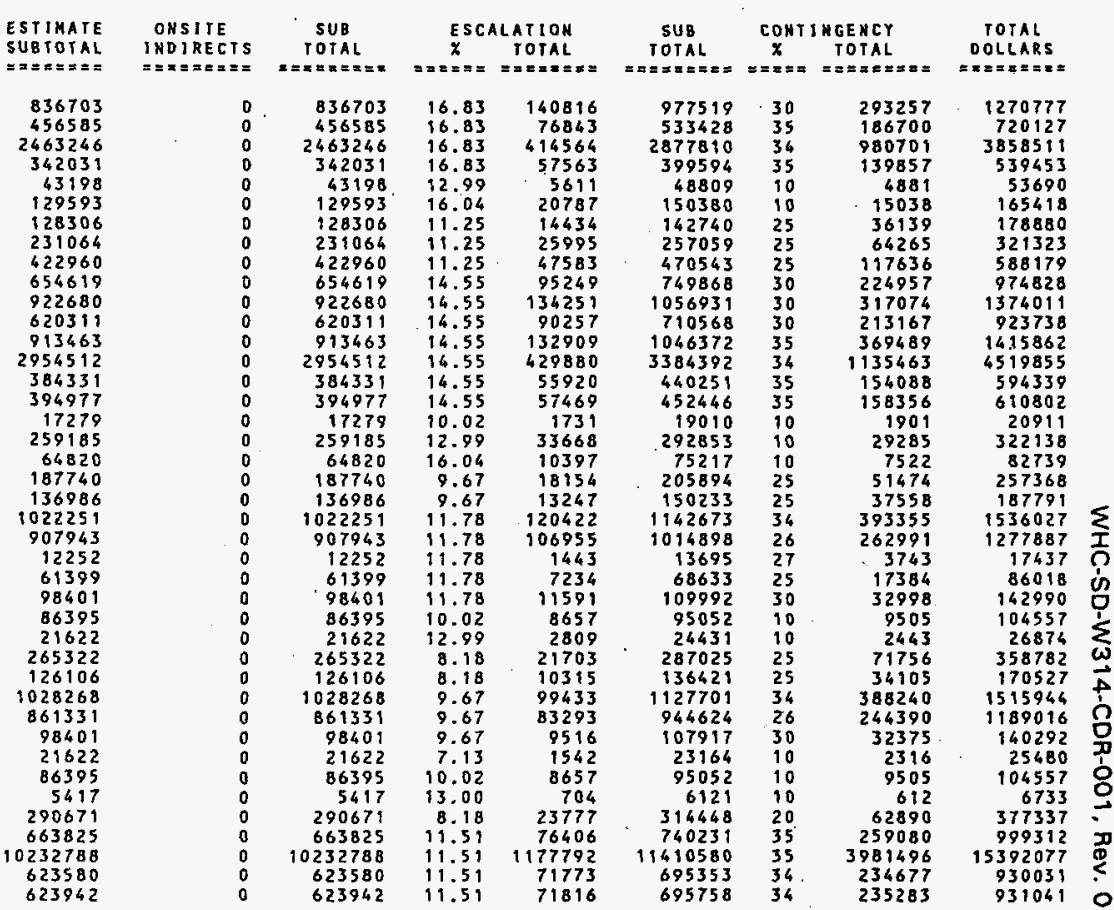

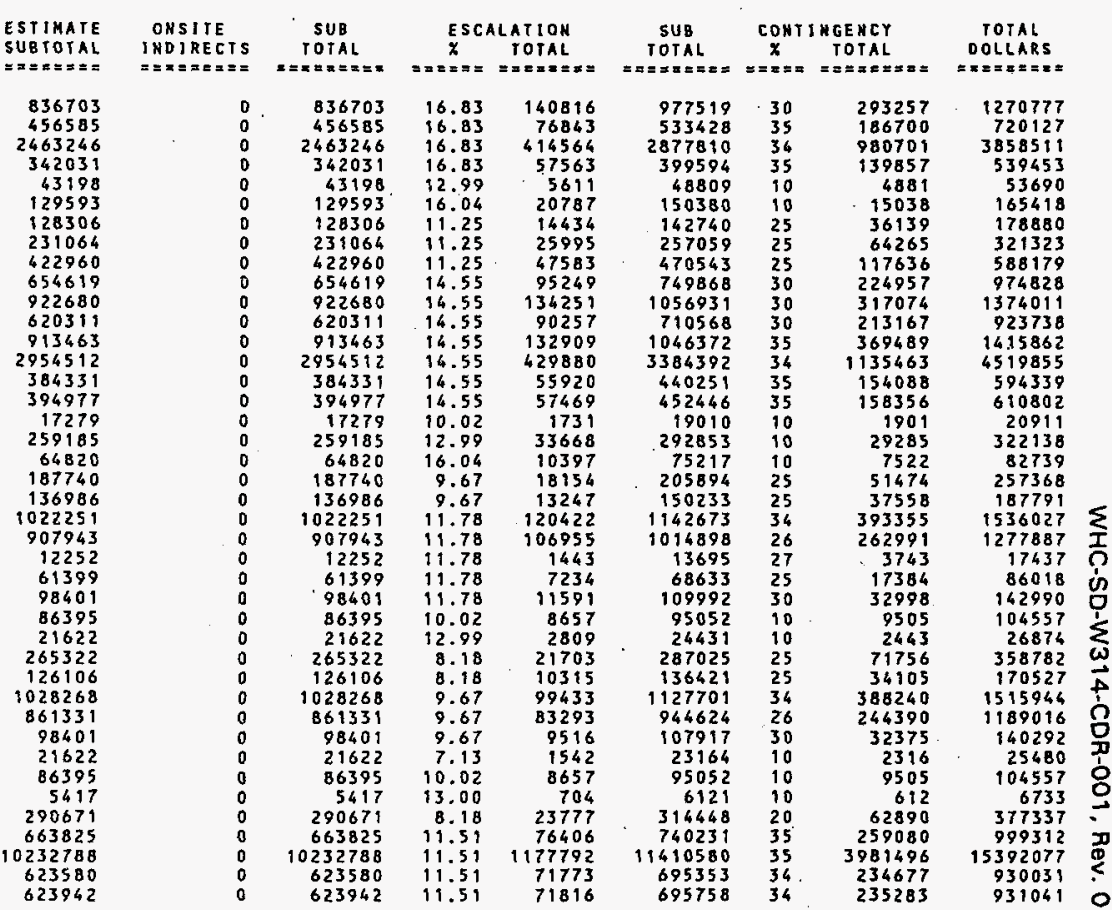

PAGE 21 OF 84 DATE 04/23/96 14:56:45

BY TLHRDP DKH JJM 
KAISER ENGINEERS HANFORD

WESTI KGHOUSE HANFORD COMPAHY

JO8 HO. W3 I4BAC2

$\cos t$

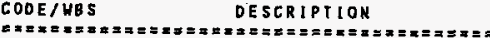

GC4E VALVE PIT $24 i-A X-A$

6CGF VALVE PIT 24$\}-A X-B$

6C4I. OFFICIAL ACCEPTANCE OF CONST.

$6 C 69$ HPT SUPPORT 6 TY 99

$6 C 62$ HPT SUPPORT FY OO

$\begin{array}{lll}6 C 63 & \text { HPT SUPPORT } & \text { FY O1 } \\ 6 C 64 & \text { HPT SUPPORT } & \text { FY O2 }\end{array}$

604A GENERAL REQUIREMENTS

605A GEMERAL REQUIRERENTS

605T TX FARM

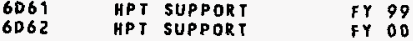

$\stackrel{T}{\sim}$

TOTAL 700 SPECIAL EQUIP/PROCESS SYSTEH 83597981

810 DEMOLITION

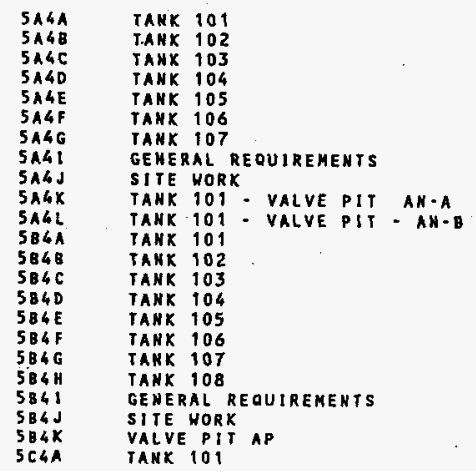

44674

14978

14978

14978

46843

46674
360413

34916

476
476

43106

43278

45015

43278

45015

43278

43278

43278

384871

476

14978

$\begin{array}{rl}44674 & 22.13 \\ 44674 & 22.13 \\ 14978 & 22.13 \\ 14978 & 22.13 \\ 14978 & 22.13 \\ 44843 & 22.13 \\ 44674 & 22.13 \\ 360413 & 22.13 \\ 34116 & 22.13 \\ 476 & 22.06 \\ 476 & 22.06 \\ 43106 & 23.64 \\ 43278 & 23.64 \\ 45015 & 23.64 \\ 43278 & 23.64 \\ 45015 & 23.64 \\ 43278 & 23.64 \\ 43278 & 23.64 \\ 43278 & 23.64 \\ 384871 & 23.64 \\ 38336 & 23.64 \\ 476 & 23.74 \\ 14978 & 12.59\end{array}$

PAGE 22 OF 84

DATE 04/23/96 14:56:45

BY TLU ROP OKH JJH
FARM RESTORATION ANO SAFE OPERATION

- 314 COHCEPTUAL ESTIMATE REV.

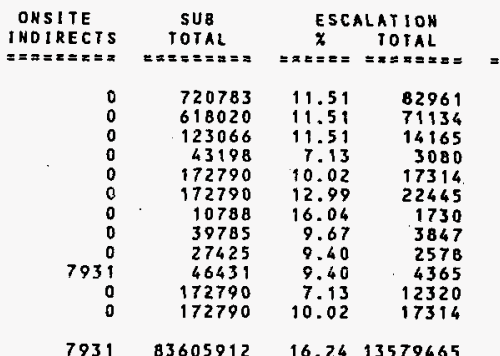

7931

3605912

$16.24 \quad 13578465$
SUB COHTINGENCY

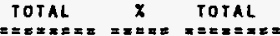

803744
689154
137231
46278
190104
19523
12518
43632
30003
50796
185110

190104

97185377

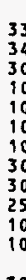

26161
23297
4116
462
1901
1952
125
13090
900
12699
1851
49010

29133085
TOTAL

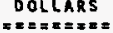

1065366

922127
178400

50906

209114

214758

13770

56722

39004

63494

203621

26318435

$\begin{array}{rrr}54560 & 30 & 16368 \\ 54560 & 30 & 16368 \\ 18292 & 30 & 5488 \\ 18292 & 30 & 5488 \\ 18292 & 30 & 5488 \\ 54766 & 30 & 16430 \\ 54560 & 30 & 16368 \\ 440173 & 30 & 132052 \\ 41665 & 35 & 14583 \\ 581 & 35 & 203 \\ 581 & 35 & 203 \\ 53297 & 30 & 15989 \\ 53510 & 30 & 16052 \\ 55658 & 30 & 16696 \\ 53510 & 30 & 16052 \\ 55658 & 30 & 16696 \\ 53510 & 30 & 16052 \\ 53510 & 30 & 16052 \\ 53510 & 30 & 16052 \\ 475854 & 35 & 166549 \\ 47396 & 35 & 16589 \\ 589 & 35 & 208 \\ 16864 & 30 & 5059\end{array}$

70928

70928

23780

23780
23780

23780
71196

70928

572226

56249

785

785

69286

69562

72354

69562

69562

69562

69562

642403

642403
63985

63985
795

21924 
KAISER EHGINEERS HANFORD WESI I HGHOUSE HAHEORO COMPAHY JOB HO. WJ1GBACZ

$\cos 5$

CODE/WBS

Description

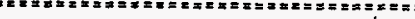

$5 \mathrm{C4B}$

$5 \mathrm{C} 4 \mathrm{C}$

5040

$5 \mathrm{CAE}$

$5 \mathrm{CHF}$

$5 C 61$

$5 \mathrm{C} 4 \mathrm{~K}$

$5 C 4 L$

$504 A$

5048

5041

$504 \mathrm{~J}$

SE4B

W $5 E 4 i$

$5 E 4 \mathrm{~J}$

$5 \% 4 A$

$5 F 48$

$5 \% 41$

$5 F 4 \downarrow$

$5 F 4 K$

$5 F 4 \mathrm{~L}$

SA4A

GA4C

$6 A 4 D$

$6 \mathrm{~B} 4 \mathrm{~B}$

$6 C 6 \mathrm{C}$

6 CC4

6260

$6 C 4 E$

$6 \mathrm{CHF}$

TOTAL 810 DEMOLITION

GENERAL REQUIREKENTS

SITE MORK

244 -5 DCRT

GENERAL REOUIREWENTS

VALVE PIT 241 -A-A

VALVE PIT $241-A-B$

VALVE PIT $241-A X-A$
VALVE PIT $241-A X-B$
* iest - Ihteractive estihating * TANK FARM RESTORATION AND SAFE DPERATIOHS

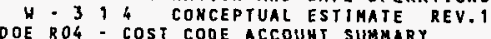

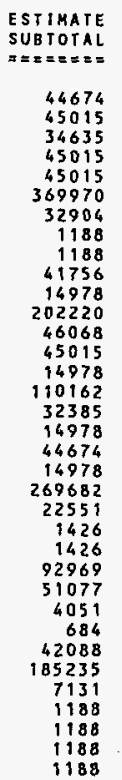

3292333

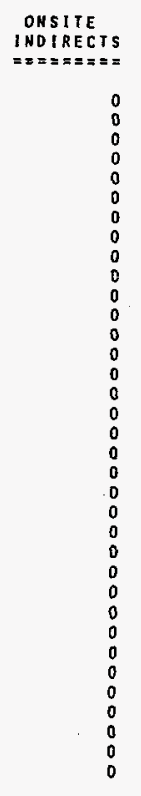

sus

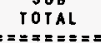

12.59

$45015-12.59$

$\begin{array}{ll}45015 & 12.59\end{array}$

369970

32904
1188

1188
1188
1756

41750

202220

202220
46068

45015

14978

110162

110162
32385

14978

44674
14978

269682

22551
1426

12.59

12.59
12.63

12.63

16.83
16.83
16.83

16.83
16.83

16.83

16.83

16.83

16.83
14.55

14.55
14.55

14.55
14.55

14.55
14.55

14.55
14.55

14.55
14.52

1426

92969

14.52

$4051 \quad 11.77$ $=x=x=x=x=x=x$

$\begin{array}{lll}45015 & 12.59 \quad 5668\end{array}$

$\begin{array}{lll}34635 & 12.59 & 4361\end{array}$

$244 \cdot A$ DCRT

900 OTHER PROJECT costs
$51077 \quad 11.78$

$684 \quad 11.84$

42088
185235

$7131 \quad 91.51$

$1188 \quad 11.53$

$1188 \quad 11.53$

202333

17.72
$1188 \quad 91.53$
4361
5668

5668

46580

4143

150
150

7027

2521
34034

34034
7753

7576
2521

2521
18540

5451

2179

6500

2179
39238

3282

207
207

207
10952

6018
4095

477
81

4070
21321

821

821
137
137

137
137
137

137

583239
PAGE 23 OF 84

DATE $04 / 23 / 96 \quad 14: 56: 46$

BY TLK RDP BKH JJK
SUB CONTINGERCY

TOTAL

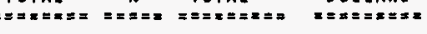

$\begin{array}{llll}50299 & 30 & 15089 & 85389\end{array}$

$\begin{array}{llll}50683 & 30 & 15205 & 65888\end{array}$

$38996 \quad 30 \quad 11699 \quad 50695$

$5068330-15205$

$\begin{array}{llll}50683 & 30 & 15205 & 65888\end{array}$

416550

37047

1338

133

478

0

236254

53821

17498

17498

128702

17157

51174

308920

25833

1633

10392

57095

4528
765

46158

206556

7952

1325

1325
1325

1325

3875572
45792

4796

12966

468
468

14636

5250

82689

1883

15778

5250
45045

13241

5146

15351

5146

108922

9042
572

572
572

3637

$199 \mathrm{~B}$

19982
1358
268

268
16155

16155

7229

464

464

464

562341

50013

1806

6349

22749

37843

72658

68369

22749

173748

51078.

66527

22305

417043

34873

2205

2205

140293

77076

5887

62313

278850

10735

1788

1788

1788

1274925

5150502 
KAISER ENGIHEERS HANFORD

WEST I NGHOUSE HAKFORO COMPAHY

JOB NO. H314BAC2

$\cos T$

CODE/HBS

DESCRIPTION

3AOO PROJECT DEFINITION

3800 PROJECT MANAGEMENT SUPPORT

3 C10 DESIGK \& CORSTR. SUPPOR

3C2O DESIGK \& CONSTR. SUPPOR

SC30 DESIGW E CONSTR. SUPPORT

3020

3030

3040

$3 E 00$

$3 F 00$

3600

3400

3100

í 3300

$3 \times 01$

$3 \times 02$

$3 \times 12$

$3 \times 21$

$3 \times 22$

$3 \times 31$

$3 \times 32$

$3 \times 41$

$3 x 4$

-10
$3 \times 4$

3r.5

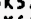

3x6

3.7.

$3 \times 8$

KK8

$3 \times 82$

$3 K 92$

3 KAO

310

(I)

3 L2

$3\llcorner 3$

$3<4$
DCBL

CONCEPTUAL DESIGN

ACOR

PRELIN SAFETY DOC

PERMITTING PLAH

NEPA DOCUHEHTATION

IE SELECTION \& PROCUREMENT

QAPP

SITE CHARACTERIZATIOY

STARTUP SUPPORT

STARTUP SUPPORT

STARTUP ENGINEERING - AP

STARTUP SUPPORT

STARTUP EHEINEERING - $A$

SIARTUP SUPPORT - AY

SIARTUP ENGINEERING - AY

STARTUP EHGIHEERING - AZ

STARTUP SUPPOR

STARTUP ENGINEERING - SY

STARTUP SUPPORT $244 A$

STARTUP SUPPORT

STARTUP EHGIHEERING - 2665

STARTUP SUPPORT $-200 \mathrm{E} / \mathrm{H}$

STARTUP ENGINEERING - 200 EIH

STARTUP SUPPORT

$-S S T$
SST

TARTUP ADHINISTRATIOH

STARTUP ADHINTSTRATIOH

READIHESS REVIEW - AP

RERDIHESS REVIEN - A

READINESS REVIEH - AY
ENGINEERING REPORT

STARTUP EMGIMEERING : AH
\#* IEST - INTERACTIVE ESTIMATIUE **

TANK FARM RESTORATIOH AND SAFE OPERATIONS

DOE_RO4: COST CODE ACCOUHT SUMMARY

ONSITE

SUBTOTAL,
$=\approx \approx=\approx \approx=\approx$

6552000

4244885

91390

925324
4735055

535000

560000

2026000

255000

18000

111000

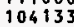

289228

1522147

982443

1005290

1510834

999608

524897

845358

845358

04535

403058

036748

936748

879835

485540

879835

485540

382865

285594

87133

3136015

1010884

1009247

1036140

811210
811865

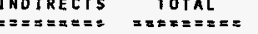

6552000

4244885

91390
925324

925324

4735055

9535000

560000

2026000

255000

18000

111000

106133

289228

1522147

982443

1005290

1510634

909609

524807

845358

1403058

936748

879835

485540

879835

485540

382865

285594

211510

3136015

1010884

1009247

1036140

811865

0.00

0.08
2.94

2.96
12.07

14.53

0.00

0.00

0.77

0.00

1.24

0.00

8.61

19.70

18.77

21.53

11.42

10.1

15.87

15.87

17.25

13.0

11.13

5.64

5.64

10.02

6.57

5.97

15.63

21.60

11.90

14.55
INOIRECTS TOTAL

$x$ TOTAL

TOTAL $X$ TONTINGENCY
TOTAL

PAGE 24 OF $B$

$5: 46$

BY TLH RDP DKH JJM

14.54

0
3232
2686
111717
687960
0
0
0
15700
0
0
2219
0
175
24909
299883
184423
344141
216465
172584
101205
83322
145842
83322
145842
182480
122453
97918
27370
97916
27370
38363
18752
20864
5798
490293
218376
247617
123304
118007
118072

6552000

4248117

1037041

5423015

208000
.535000

50

2041700

255000

18000

180565

111000

$3: 4137$

1822030

1166866

1849183

1221755

1683218

608210

891200

991200

00829

51200

158553

1059201

512910

977751

512910

421228

102931

1229260

1259260

929217

929937
$=$
0
0
10
10
10
0
0
0
5
0
0
10
1
10
10
10
10
10
10
10
10
10
10
10
10
10
10
10
10
10
10
10
10
10
10
10
10
10
10
10
10

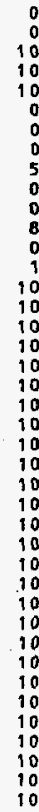

TOTAL $=x= \pm x= \pm x=$

8552000

4269029

1140744

5965317

208000

9535000

143270

255000

18000

111000

105439

345552
2004231

1283552

2034102

1343931

1851539

1210895

669040

1090320

669040

1165121

564209

564201

564201

463351

33478

2556ro

113223

1382550

1275387

1022931

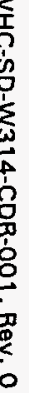


XAISER EMGINEERS HAHFORD

WESTIKGHOUSE HANFORD COMPANY

JOB HO. H314BAC?

$\cos r$

CODE/KBS

DESCRIPTION

$3<51$

$3\llcorner 61$

$3\llcorner 71$

$3<81$

$3 M O 1$

$3 M 02$

$3 \rightarrow 03$

$3 \times 04$

$3 M 05$

$3 M 06$
3 MOT

$\stackrel{?}{1}$

TOTAL 900

REAOINESS REVIEH - SY

READINESS REVIEW - 244

REAOINESS REVIEH - 244 S

REAOINESS REVIEY = $200 \mathrm{E} / \mathrm{H}$

READJNESS REVIEW - SST

INO REV. SYSTEMS ENG. MGMT. - FY 98

IND. REV.SYSTEMS ENG. NGMT. - FY 99

IND. REV.SYSTEMS ENG. MGMT. - FY OO

IND. REV.SYSTEMS ENG. MGMT. - FY O

IND. REY SYSTERS ENG. MGNT. - FY O

IND. REV.SYSTEHS ENG. MGMT: - FY O5

PROJECT TOTAL
* IEST - InTERACTIVE ESTIMATIHG *

TANK FARM RESTORATION

W - 314 CONCEPTUAL ESTIMATE REV. 1

DOE_RO - COST CDDE ACCOUNT SUMMARY

ESTIKAT
SUBTOTA
$======$

99400
76370
76370
48459
12042
16000
26000
18000
22000
10000
2000
2000

58048488

INDIRECTS

SUB
TOTAL

ESCALATION
$*$ TOTAL

$= \pm= \pm= \pm=\equiv$

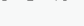

(1)
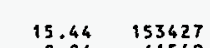

$\begin{array}{lll}763701 & 8.06 & 61549\end{array}$

$763709 \quad 9.01 \quad 68844$

$\begin{array}{lll}484599 & 10.02 & 48557\end{array}$

$120423 \quad 6.88 \quad 8282$

260000

180000

220000

100000

20000

4.31

7.13
0.02

12.99

16.04

25.69

20000

30.00

0 $\quad 38048488$

8.655020463
PAGE 25 OF 84

$16: 56: 46$

BY TLW RDP DKH JJM

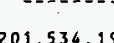

323,000

$25,659,872$

$227,517,074$

20

$45,656,973$

$201,534,192$

$201,857,192$

12.71 
KAISER EMGIMEERS HAHFORD WESTINGHOUSE HAHFORD COMPANY JOB NO. W314BAC2

CS I

DESCRIPTION

CONSTRUCTION

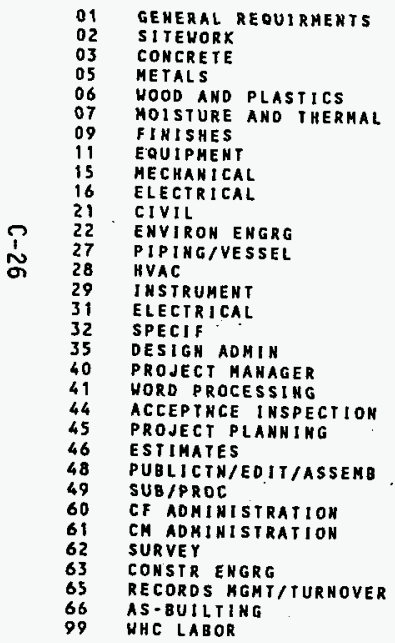

TOTAL CONSTRUCTIOH

PROJECT TOTAL
* IEST - INTERACTIVE ESTIMATIHG **

TANK FARM RESTORATION AND SAFE OPERATIONS DOE_ROS - ESTIMATE SUMMARY BY CSI DIVISION
PAGE 26 OF 84

DATE $04 / 23 / 96 \quad 16: 57: 05$

BY TLW RDP OKH JJK

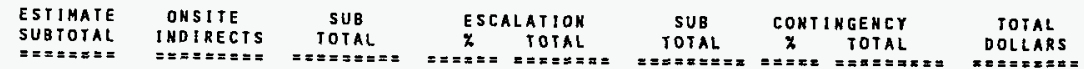

\begin{tabular}{|c|c|c|c|c|c|c|c|c|}
\hline $\begin{array}{r}32796220 \\
13363860 \\
1103856 \\
604224 \\
417589 \\
1010970 \\
2590332 \\
4080 \\
13792932 \\
19079071 \\
2650585 \\
259844 \\
4305781 \\
2261131 \\
10920034 \\
4002134 \\
148784 \\
3190778 \\
8061086 \\
78722 \\
1113853 \\
2315857 \\
1318441 \\
23390 \\
424379 \\
286078 \\
2834 \\
279533 \\
431296 \\
377115 \\
1721095 \\
72598308\end{array}$ & $\begin{array}{r}7931 \\
79428 \\
0 \\
0 \\
0 \\
0 \\
0 \\
0 \\
0 \\
0 \\
235641 \\
0 \\
0 \\
0 \\
0 \\
0 \\
0 \\
0 \\
0 \\
0 \\
0 \\
0 \\
0 \\
0 \\
0 \\
0 \\
0 \\
0 \\
0 \\
0 \\
0 \\
0 \\
0\end{array}$ & $\begin{array}{r}32806151 \\
13443288 \\
1103856 \\
604224 \\
417589 \\
1010970 \\
2590332 \\
4080 \\
13792932 \\
19314712 \\
2650585 \\
259844 \\
4305781 \\
2261131 \\
10920034 \\
4002134 \\
148784 \\
3190778 \\
8061086 \\
78722 \\
1113853 \\
2315857 \\
1318441 \\
23390 \\
426379 \\
286078 \\
2834 \\
279533 \\
431296 \\
377115 \\
1721095 \\
72598308\end{array}$ & $\begin{array}{r}17.11 \\
14.71 \\
15.38 \\
19.45 \\
16.27 \\
17.88 \\
18.17 \\
11.25 \\
15.53 \\
15.78 \\
9.91 \\
12.33 \\
9.05 \\
9.96 \\
10.96 \\
9.33 \\
11.04 \\
11.65 \\
13.00 \\
12.31 \\
18.28 \\
11.69 \\
10.39 \\
3.93 \\
3.81 \\
9.97 \\
3.92 \\
8.37 \\
11.19 \\
13.40 \\
14.98 \\
9.52\end{array}$ & $\begin{array}{r}5612537 \\
1977104 \\
169749 \\
117542 \\
67951 \\
180802 \\
470671 \\
459 \\
2941374 \\
3047346 \\
262730 \\
32048 \\
389792 \\
225313 \\
1196669 \\
373560 \\
16431 \\
371829 \\
1047604 \\
9693 \\
203589 \\
270630 \\
137043 \\
919 \\
16175 \\
28524 \\
111 \\
23405 \\
48267 \\
50536 \\
257809 \\
6911660\end{array}$ & $\begin{array}{r}38416688 \\
15420392 \\
1273605 \\
721766 \\
485540 \\
1191772 \\
3061003 \\
4539 \\
15934306 \\
22362068 \\
2913395 \\
291892 \\
4695573 \\
2486444 \\
12116703 \\
4375694 \\
165215 \\
3562607 \\
9108690 \\
88415 \\
1317442 \\
2586487 \\
1455484 \\
24309 \\
440554 \\
314602 \\
2945 \\
302938 \\
479563 \\
427651 \\
1978904 \\
79509968\end{array}$ & $\begin{array}{l}32 \\
32 \\
29 \\
25 \\
34 \\
27 \\
32 \\
35 \\
29 \\
30 \\
19 \\
20 \\
19 \\
19 \\
20 \\
19 \\
20 \\
20 \\
20 \\
20 \\
20 \\
20 \\
20 \\
15 \\
17 \\
19 \\
15 \\
18 \\
20 \\
20 \\
20 \\
7\end{array}$ & $\begin{array}{r}12168232 \\
4873481 \\
372510 \\
180441 \\
163245 \\
327056 \\
970733 \\
1589 \\
4685265 \\
6648405 \\
558848 \\
58379 \\
883612 \\
469609 \\
2373806 \\
835976 \\
33044 \\
702316 \\
1798459 \\
17350 \\
263433 \\
508585 \\
284026 \\
3646 \\
72998 \\
61277 \\
462 \\
55732 \\
95912 \\
85199 \\
395781 \\
5707594\end{array}$ & $\begin{array}{r}50584895 \\
20293884 \\
1646109 \\
902207 \\
648788 \\
1518821 \\
4031744 \\
6128 \\
20619543 \\
29010488 \\
3472179 \\
350269 \\
5579193 \\
2956050 \\
14490508 \\
5211666 \\
198261 \\
4264921 \\
10907138 \\
105766 \\
1580873 \\
3095073 \\
1739514 \\
27956 \\
513554 \\
375880 \\
3387 \\
358672 \\
575476 \\
512848 \\
2374686 \\
85217563\end{array}$ \\
\hline
\end{tabular}
$201,534,192 \quad 323,000 \quad 201,857,19212,71^{25,659,872} 227,517,074 \quad 20^{45,656,973} 273,174,040$ $273,174,040$

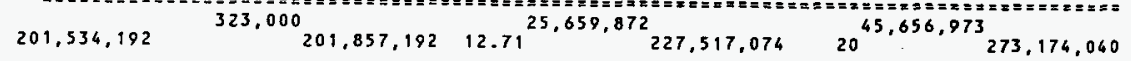


NESTIHGHOUSE HANFORD COMPANY

KAISER ENGIMEERS HANFORD

JOB NO. W314OBAC2

FILE "U3 $14 \mathrm{BAC2}$
* IEST. INTERACTIVE ESTIMATING **

TAHK FARM RESTORATION AHD SAFE OPERATIONS W - 314 CORCEPTUAL ESTIMATE REV.

DOE_ROG - CONTIMGENCY ANALYSIS BASIS SHEET
PAGE 27 OF B6

DATE $04 / 23 / 96$

BY T.L. OWALOO

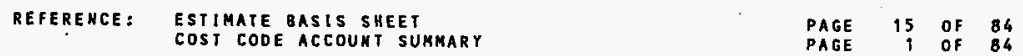

THE U.S. DEPARIMENT OF ENERGY - ORICHLAND ORDER 5700.3 "COST ESTIMATING ANALYSIS AND STANDARDIZATIOH" OATEO 3-27-85, PROVIDES GUIDELINES FOR ESTIMATE COHTIHOENCIES. THE GUIDELINE FOR A COHCEPTUAL ESTIMATE SHOULO HAVE AH OVERALL RANGE OF 15 TO $40 \%$.

CONTIHGENCY IS EVALUATED AT THE FHIRD COST CODE LEVEL ANO SUMMARIZED AT THE PRIMARY AHD SECOHDARY COST CODE LEVEL OF THE DETAILED COST ESTIMATE.

010

TIILE I

020

ITLE II

030

TIYLE III

080

PROJECT MANAGEMENT
A $15 \%$ CONTIMGENCY WAS APPLIED DUE TO UNCERTAIHTIES IN THE LEVEL OF DETAIL THAT HILL BE PROVIDED IN THE DESIGH CONFIGURATION BASELIHE DOCUMENT.

A 20\% CONTINGENCY HAS APPLIEO DUE TO UNCERTAINTIES IN THE IDENTITY AHO SEQUENCE OF THE TEN TANKS; CHANGES IN TECHHOLOGY OVER THE LIFE OF THE PROJECT: UTILIZATIOH DF UHPROVEN EQUIPMENT TO BE INSTALLEO BY OTHER PROJECTS, (OEG. H-151, W-320); TAHK WASTE CHARACTERIZATION (i.e. DOME LOADING, TANK TEMPERATURES, CHEMICAL AND PHYSICAL PROPERTIES, OPERATING COHDITIONS ETC.); ANO CHANGES IH TITLE II COST HHEM DETALLED PLANNIHG IS PERFORMED.

A 20\% CONTINGENCY HAS APPLIED DUE TO UNCERTAINTIES IH TITLE II DESIGH (ABOVE); QUALITY, COMPLESENESS AND TIMELINESS OF RECEIPT OF VENDOR SUBAITTALS; AVAJLABILITY AND ACCURACY OF EXISTIHG TANK FARM DRAW:HGS; NEED FOR REVISED CONSTRUCTION METHODS TO MINIMIZE DOSE; REQUIREMEHTS FOR H.14 ESSEKTIAL ORANINGS; AND SCOPE OF ACCEPTANCEI INSPECTION ANO AS-BUILDIHG WORK. AN AVERAGE OF $10 \%$ CONTINGENCY WAS APPLIEO DUE TO UHCERTAINTIES IN PERMITTING DACIIV-
DITIES AND SAFETY AHALYSIS: MULTIPLE IIER REVIEUS OF PERMITIING AND SAFETY DOCUMENTS;

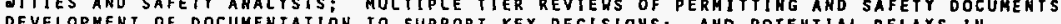
DECETPT OF KEY DECISIONS. 
HESTINGHOUSE HANFORD COMPANY

KAISER ENGINEERS HANFORD

JOB NO. H314BAC2

FILE \# W314BAC2
600 UTILITIES

700 SPECIAL EQU1P/PROCESS SYSTEKS

$\stackrel{?}{1}$

810 DEMOLITION

900

OTHER PROJECT COSTS

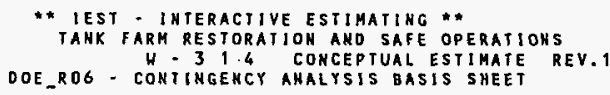

CONSTRUCTION
AVERAGE PROJECT COHTINGEHCY
PAGE 28 OF 84

BY T.L. WALDO 
KAISER ENGIHEERS KAMFORD

WEST INGHOUSE HAHFORD COHPANY

SOB HO. 4396 BAC?

WB

DESCRIPTION

PH INTEGRATION TITLE - I

1 AOZ PM INTEGRATION TITLE - I

1 AOS PH TNTEGRATIOH - CONST.

1801 SYSTEHS EHG. MGMT. - TITLE !

1802 SYSTEMS ENG. MGHT. - TITLE I

1803 SYSTENS EHG. MGMT. - CONST

ICOI PC/BUSINESS MGMT - TITLE,

$1 C 02$ PC/BUSIHESS MEMT - TITLE I

1 CO3 PC/BUSIRESS MGHT - COHST

1009 QUALITY ASSURANCE - IIILE I

IDOZ QUALITY ASSURANCE - TITLE

guality assurance - const.

AIR PERHITTING

PART B DANGEROUS HASTE PERMITS

2A03 PRE-OP DETERMIHATIOH

2800

3400

3800

3020

3030

3010

3010

3020

3040

$3 E 00$

$3 F 00$

3600

3 HOO

3100

$3 \mathrm{JOO}$

$3 \times 09$

$3 \mathrm{KO2}$

$3 \mathrm{KIZ}$

3 Kर:

$3 \times 22$

$3 \times 31$

$3 \times 32$

$3 \times 61$

SAFETY AHALYSIS

PROJECT DEFIHITION

PROJECT MANAGEHENT SUPPORT

OESIGN CONSTR. SUPPORT

DESIGN CONSTR. SUPPORT

DESIGH \& CONSIR. SUPPORT

ENGINEERING REPOR I

CBL

COHCEPTUAL DESIGH

PRELIM SAFETY DOC

PERMITTING PLAH

NEPA OOCUMENTATION

A/E SELECTION \& PROCURERENT

SITE CHARACTERIZATIOH

STARTUP SUPPORT - AN

STARTUP ENGINEERING - AN

STARTUP SUPPORT - AP

STARTUP EHGINEERING - AP

STARTUP SUPPORT

STARTUP ENGINEERIHG - AH

STARTUP SUPPORT

STARTUP SUPPORT -AZ

STARTUP ENGINEERING - AZ
* * IEst - interactive estimating *

TANK FARM RESTORATION AHD SAFE OPERATIONS O - 314 CONCEPTUAL ESTIMATE REV. 1 DOE_ROT - ONSITE IMOIRECI COSTS BY HBS

\begin{tabular}{|c|c|c|}
\hline $\begin{array}{l}\text { ESTIMATE } \\
\text { SUBTOTAL } \\
==\pi===\equiv\end{array}$ & $\begin{array}{r}\text { COKTRACT } \\
=z=z=\end{array}$ & $\begin{array}{c}\text { AOMINISTRATIOI } \\
\text { TOTAL } \\
=== \pm=\equiv=E\end{array}$ \\
\hline $\begin{array}{r}427746 \\
2239150 \\
2320133 \\
471240 \\
793968 \\
573750 \\
248799 \\
846564 \\
585178 \\
220742 \\
551855 \\
441684 \\
81043 \\
60534 \\
3077 \\
1151886 \\
6552000 \\
4244885 \\
91390 \\
925324 \\
4735055 \\
208000 \\
9535000 \\
560000 \\
2026000 \\
255000 \\
18000 \\
178346 \\
111000 \\
104133 \\
289228 \\
1522147 \\
982443 \\
1505042 \\
1005290 \\
1510634 \\
999609 \\
524897 \\
845358 \\
524897 \\
845358\end{array}$ & $\begin{array}{l}0.00 \\
0.00 \\
0.00 \\
0.00 \\
0.00 \\
0.00 \\
0.00 \\
0.00 \\
0.00 \\
0.00 \\
0.00 \\
0.00 \\
0.00 \\
0.00 \\
0.00 \\
0.00 \\
0.00 \\
0.00 \\
0.00 \\
0.00 \\
0.00 \\
0.00 \\
0.00 \\
0.00 \\
0.00 \\
0.00 \\
0.00 \\
0.00 \\
0.00 \\
0.00 \\
0.00 \\
0.00 \\
0.00 \\
0.00 \\
0.00 \\
0.00 \\
0.00 \\
0.00 \\
0.00 \\
0.00 \\
0.00\end{array}$ & $\begin{array}{l}0 \\
0 \\
0 \\
0 \\
0 \\
0 \\
0 \\
0 \\
0 \\
0 \\
0 \\
0 \\
0 \\
0 \\
0 \\
0 \\
0 \\
0 \\
0 \\
0 \\
0 \\
0 \\
0 \\
0 \\
0 \\
0 \\
0 \\
0 \\
0 \\
0 \\
0 \\
0 \\
0 \\
0 \\
0 \\
0 \\
0 \\
0 \\
0 \\
0 \\
0\end{array}$ \\
\hline
\end{tabular}

PAGE 29 OF 84

$14: 57: 18$

BY TLW RDP DKH JJM

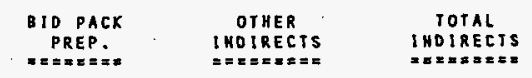


KAISER ENGIHEERS HANFORD

NESTIMGHOUSE HAHFORD COMPANY

JOE NO. H314BAC2.

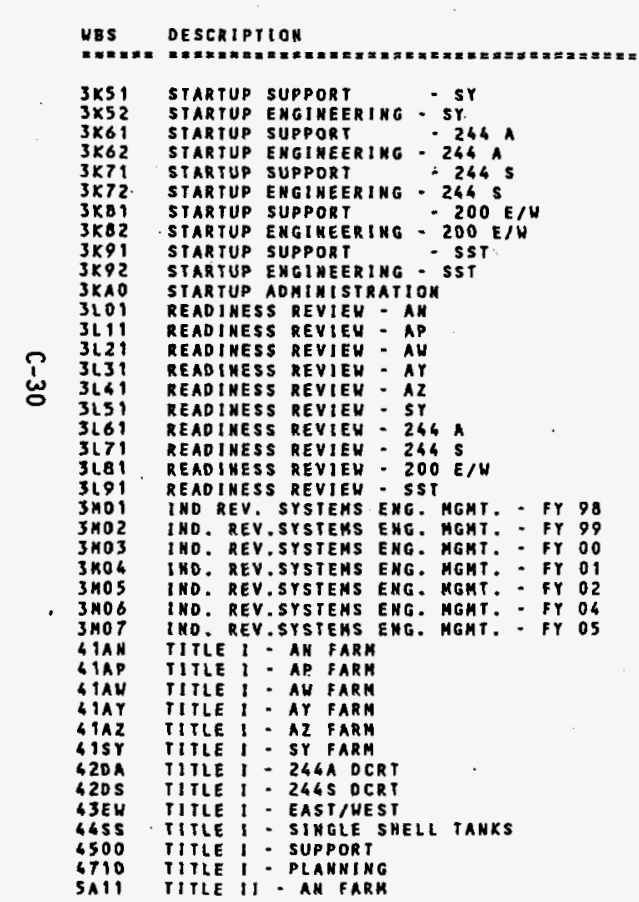

* IEST - interactive estimating *

IANR FARM RESTORATION AKD SAFE OPERATIOHS DOE_ROT - ONSIIE INOIRECT COSTS BY HBS

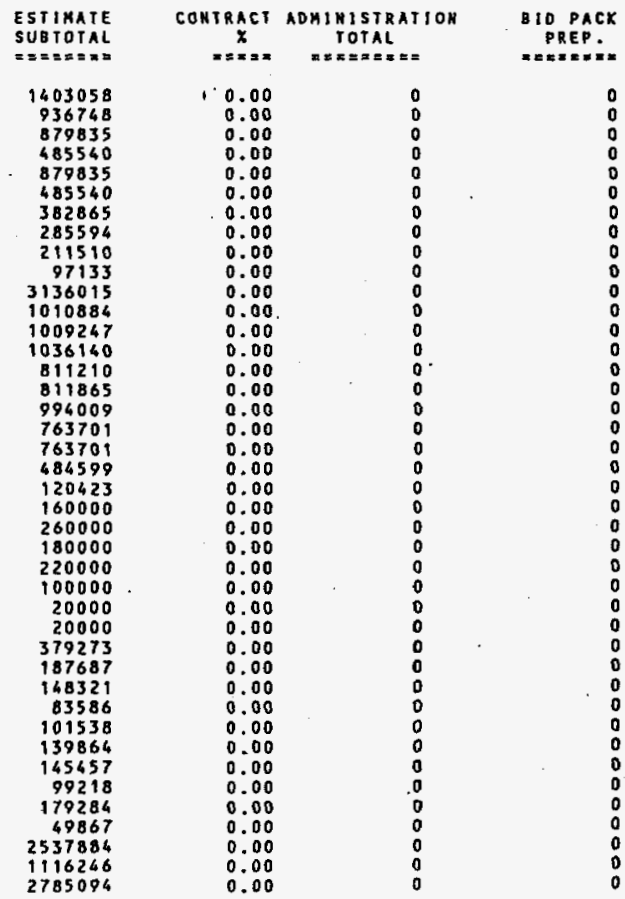

PAGE 30 OF 84

$16: 57: 19$

gY ILW ROP OKH JJU

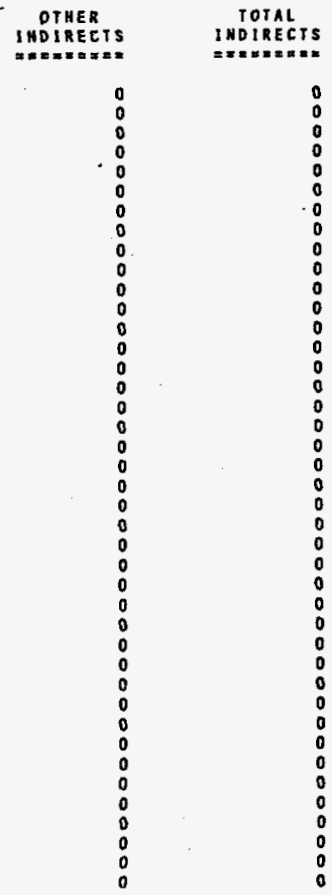


KAISER EMGIMEERS HANFORO

WESIIHGHOUSE HANFORD COMPAMY

JOB MO. H3 16 BACZ
* IEST - INTERACTIVE ESTIMATING *

TAHK FARM RESTORATION AND SAFE OPERATI ONS

OOE_ROT " ONSITE INOIRECT COSTS BY HBS

\begin{tabular}{|c|c|c|}
\hline $\begin{array}{l}\text { ESITMAIE } \\
\text { SUB TOTAL } \\
===\equiv=\equiv=\end{array}$ & 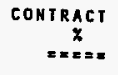 & $\begin{array}{c}\text { ADMINISTRATIOH } \\
\text { TOTAL } \\
=x=x=\pi x=x\end{array}$ \\
\hline $\begin{array}{r}963857 \\
2429600 \\
741394 \\
710675 \\
717979 \\
688709 \\
566071 \\
566567 \\
565954 \\
672716 \\
689039 \\
3187789 \\
3534871 \\
590195 \\
606871 \\
64820 \\
259185 \\
259185 \\
2293977 \\
931337 \\
1778622 \\
1355706 \\
710675 \\
621669 \\
911302 \\
699941 \\
620430 \\
693750 \\
626074 \\
617632 \\
617859 \\
2367628 \\
4893232 \\
631213 \\
21622 \\
259185 \\
259185 \\
194412 \\
2398717 \\
1010033 \\
1700770\end{array}$ & $\begin{array}{l}0.00 \\
0.00 \\
0.00 \\
0.00 \\
0.00 \\
0.00 \\
0.00 \\
0.00 \\
0.00 \\
0.00 \\
0.00 \\
0.00 \\
0.00 \\
0.00 \\
0.00 \\
0.00 \\
0.00 \\
0.00 \\
0.00 \\
0.00 \\
0.00 \\
0.00 \\
0.00 \\
0.00 \\
0.00 \\
0.00 \\
0.00 \\
0.00 \\
0.00 \\
0.00 \\
0.00 \\
0.00 \\
0.00 \\
0.00 \\
0.00 \\
0.00 \\
0.00 \\
0.00 \\
0.00 \\
0.00 \\
0.00\end{array}$ & $\begin{array}{l}0 \\
0 \\
0 \\
0 \\
0 \\
0 \\
0 \\
0 \\
0 \\
0 \\
0 \\
0 \\
0 \\
0 \\
0 \\
0 \\
0 \\
0 \\
0 \\
0 \\
0 \\
0 \\
0 \\
0 \\
0 \\
0 \\
0 \\
0 \\
0 \\
0 \\
0 \\
0 \\
0 \\
0 \\
0 \\
0 \\
0 \\
0 \\
0 \\
0 \\
0\end{array}$ \\
\hline
\end{tabular}

PAGE. 31 OF 84

DATE 04/23/96 14:57:19

OY TLY RDP DKH JJI

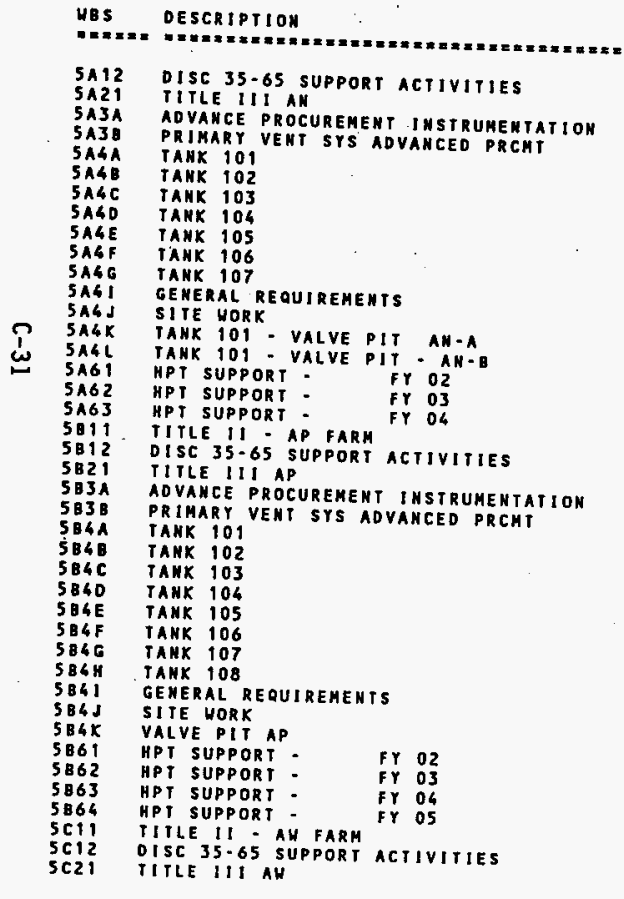

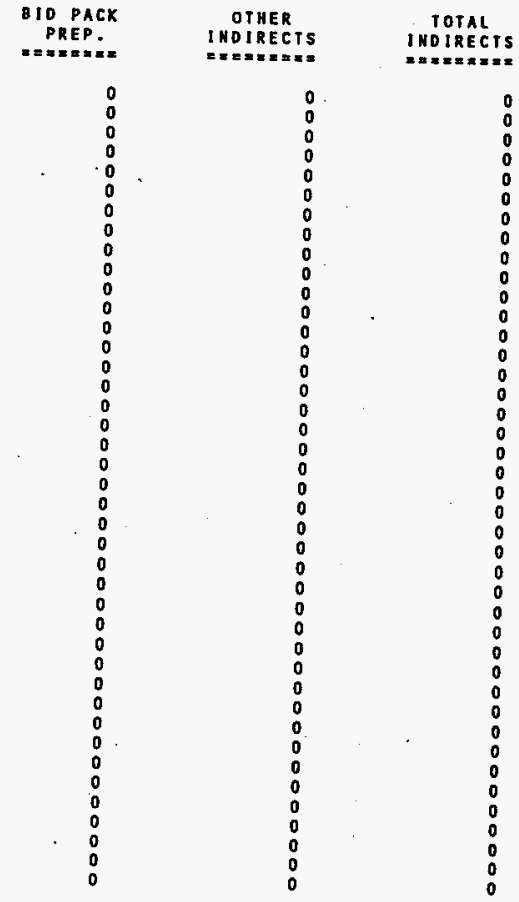


KAISER ENGIHEERS HAMFORD

WEST INGHOUSE MAHFORD COMPANY

JOB NO. H314BACZ
* 1EST * InTERactive estihatimg * TANK FARM RESTORATION aHO SAFE OPERATIOHS DOE HOT - 3 T OOE_RO7 - ONSITE INDIRECT COSTS BY HES

\begin{tabular}{|c|c|c|}
\hline $\begin{array}{l}\text { ESTIMATE } \\
\text { SUBTOTAL } \\
=\approx x=\approx=\approx=\end{array}$ & $\begin{array}{r}\text { CONTRACT } \\
=\underset{x}{= \pm=}\end{array}$ & $\begin{array}{c}\text { ADNINISTRATION } \\
\text { TOTAL } \\
= \pm=x=a=x\end{array}$ \\
\hline $\begin{array}{r}744522 \\
762960 \\
633663 \\
1009575 \\
675599 \\
635935 \\
669408 \\
677753 \\
2174422 \\
5652186 \\
421717 \\
423455 \\
282214 \\
21622 \\
259185 \\
259185 \\
21622 \\
1497662 \\
863261 \\
1109078 \\
275594 \\
1525387 \\
1468392 \\
638032 \\
2682461 \\
43198 \\
1129593 \\
1538459 \\
845453 \\
1117151 \\
263356 \\
1087273 \\
851681 \\
566747 \\
2495631 \\
362031 \\
43198 \\
1129593 \\
1996241 \\
882032 \\
1262030\end{array}$ & $\begin{array}{l}0.00 \\
0.00 \\
0.00 \\
0.00 \\
0.00 \\
0.00 \\
0.00 \\
0.00 \\
0.00 \\
0.00 \\
0.00 \\
0.00 \\
0.00 \\
0.00 \\
0.00 \\
0.00 \\
0.00 \\
0.00 \\
0.00 \\
0.00 \\
0.00 \\
0.00 \\
0.00 \\
0.00 \\
0.00 \\
0.00 \\
0.00 \\
0.00 \\
0.00 \\
0.00 \\
0.00 \\
0.00 \\
0.00 \\
0.00 \\
0.00 \\
0.00 \\
0.00 \\
0.00 \\
0.00 \\
0.00 \\
0.00\end{array}$ & $\begin{array}{l}0 \\
0 \\
0 \\
0 \\
0 \\
0 \\
0 \\
0 \\
0 \\
0 \\
0 \\
0 \\
0 \\
0 \\
0 \\
0 \\
0 \\
0 \\
0 \\
0 \\
0 \\
0 \\
0 \\
0 \\
0 \\
0 \\
0 \\
0 \\
0 \\
0 \\
0 \\
0 \\
0 \\
0 \\
0 \\
0 \\
0 \\
0 \\
0 \\
0 \\
0\end{array}$ \\
\hline
\end{tabular}

PAGE 32 OF 84

DATE O4/23/96 14:57:19

BY TLN ROP DKH IJH

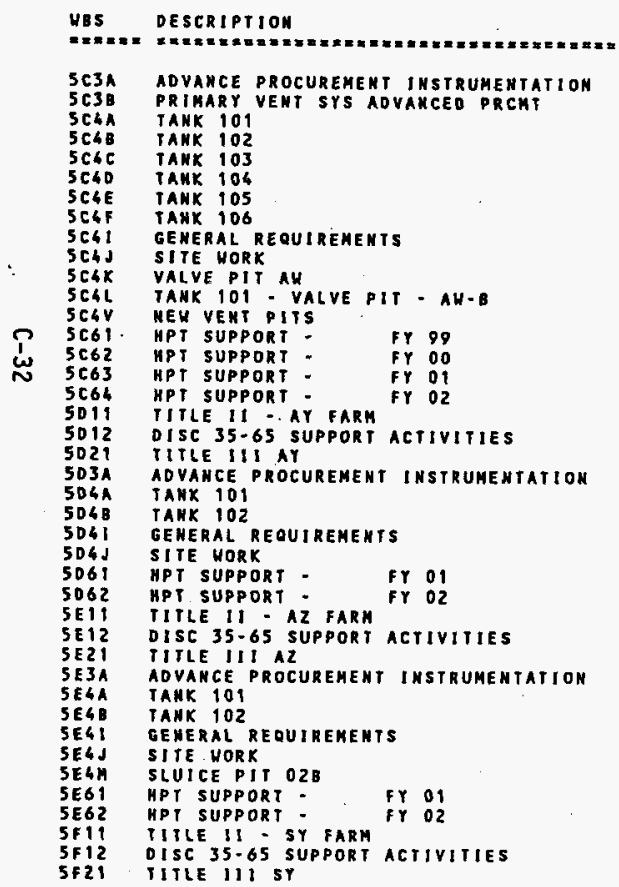

\begin{tabular}{|c|}
\hline $\begin{array}{l}0 \\
0 \\
0 \\
0 \\
0 \\
0 \\
0 \\
0 \\
0 \\
0 \\
0 \\
0 \\
0 \\
0 \\
0 \\
0 \\
0 \\
0 \\
0 \\
0 \\
0 \\
0 \\
0 \\
0 \\
0 \\
0 \\
0 \\
0 \\
0 \\
0 \\
0 \\
0 \\
0 \\
0 \\
0 \\
0 \\
0 \\
0 \\
0 \\
0 \\
0\end{array}$ \\
\hline
\end{tabular}

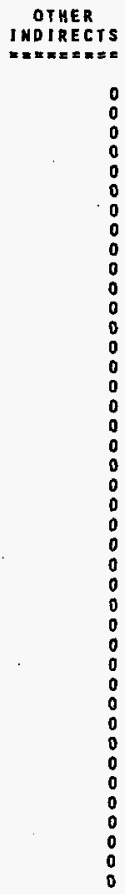

TOIAL

INDIRECTS 
KAISER EMGINEERS HANFORO WESTIUGHOUSE HAKFORD CONPAHY JOQ NO. H314BAC?

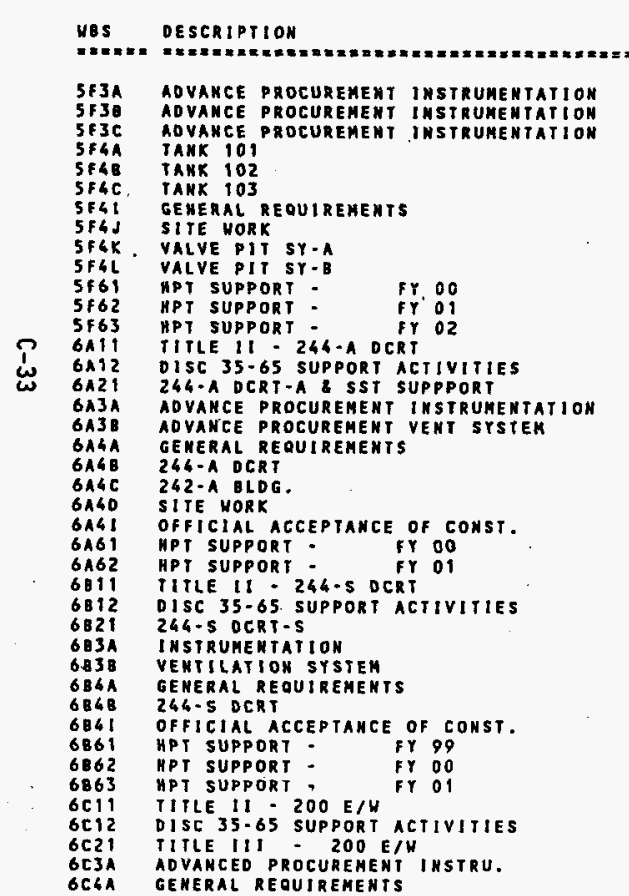

* IEST - InTERACTIVE ESTIMATIHG * TAHK FARM RESTORATION AND SAFE OPERATIONS DOE

\begin{tabular}{|c|c|c|}
\hline $\begin{array}{l}\text { ESTIMATE } \\
\text { SUBTOTAL } \\
=x=\pi=\geq x=\end{array}$ & $\underset{x=x=0}{\operatorname{CONTRACT}}$ & $\begin{array}{l}\text { ADHINISTRATION } \\
\text { TOIAL } \\
=x=x= \pm==\end{array}$ \\
\hline $\begin{array}{r}128306 \\
231064 \\
422960 \\
669597 \\
967354 \\
635289 \\
1183145 \\
2977063 \\
385757 \\
396403 \\
17279 \\
259185 \\
64820 \\
1437084 \\
498886 \\
711971 \\
187740 \\
136986 \\
1115220 \\
959020 \\
16303 \\
62083 \\
98401 \\
86395 \\
21622 \\
1322890 \\
440034 \\
862125 \\
265322 \\
126106 \\
1028268 \\
943671 \\
98401 \\
21622 \\
86395 \\
5417 \\
2668788 \\
843857 \\
1333463 \\
290671 \\
849060\end{array}$ & $\begin{array}{l}0.00 \\
0.00 \\
0.00 \\
0.00 \\
0.00 \\
0.00 \\
0.00 \\
0.00 \\
0.00 \\
0.00 \\
0.00 \\
0.00 \\
0.00 \\
0.00 \\
0.00 \\
0.00 \\
0.00 \\
0.00 \\
0.00 \\
0.00 \\
0.00 \\
0.00 \\
0.00 \\
0.00 \\
.0 .00 \\
0.00 \\
0.00 \\
0.00 \\
0.00 \\
0.00 \\
0.00 \\
10.52 \\
0.00 \\
0.00 \\
0.00 \\
0.00 \\
0.00 \\
0.00 \\
0.00 \\
0.00 \\
0.000\end{array}$ & $\begin{array}{r}0 \\
0 \\
0 \\
0 \\
0 \\
0 \\
0 \\
0 \\
0 \\
0 \\
0 \\
0 \\
0 \\
0 \\
0 \\
0 \\
0 \\
0 \\
0 \\
0 \\
0 \\
0 \\
0 \\
0 \\
0 \\
0 \\
0 \\
0 \\
0 \\
0 \\
0 \\
1430 \\
0 \\
0 \\
0 \\
0 \\
0 \\
0 \\
0 \\
0 \\
0\end{array}$ \\
\hline
\end{tabular}

PAGE 33 OF 84 DATE O4/23/96 14:57:19 BY TLURDP DKH JJM
OTHER

1 HOIRECTS

TOTAL

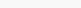


KAISER ENGIMEERS HAHFORD VESTIHGHOUSE HAMFORD COHPANY

JOB HO. U314BACZ
* IEST - INTERACTIVE ESTIMATIME * TANK FARM RES DANK FARM RESTORATION AND SAFE OPERATMONS DOE_ROT - ONSITE INOIRECT COSTS BY HBS
PAGE 34 OF 84

BY TLN ROP DXH JJH

\section{WOS DESCRIPTION}

\section{GC4B GEMERAL REQUIREMENTS}

GC4C VALVE PIT $249-A-A$

6C4D VALVE PIT $241-A-B$

GLGE VALVE PIT $241-A X-A$

6C4F VALDE PIT $241-A X-B$

GC4) OFFICIAL ACCEPIANCE OF CONST.

6C61 HPY SUPPORT FY 99

6C62 HPI SUPPORT FY

6C63 HPI SUPPORT FY OI

6C64 HPI SUPPORT

6012 DISC 35.65 SUPPORT ACTIVITIES

6021 TITLE III ENG. DURIKG CONST.

W

6OSA GENERAL REQUTREMENTS

6D5B A FARH

CDSC AX FARM

6050 B FARM

GDSF BY FARM

GOSG EY FARH

6DSH T FARM

GOS! TX FARM

GDSJ IY FARM

GOSK S FARM

6DSL SY FARM

6DSM U FARM

GDS

6062

$\begin{array}{ll}\text { HPT SUPPORT } & \text { FY } 99 \\ \text { HPT SUPPORT } & \text { FY OO }\end{array}$

PROJECT TOTAL

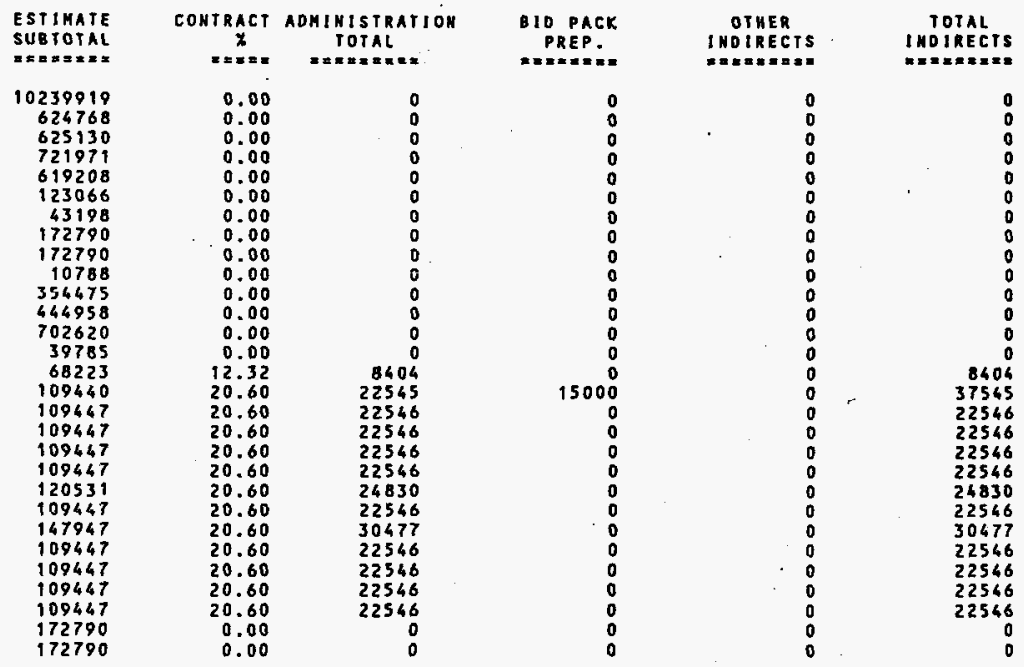

$=z x=5=x=2=$
$201,534,192$

19,500

303,500

323,000 
WHC-SD-W314-CDR-001, Rev. 0

Page 35 of 84

ENGINEERING STATEMENT OF WORK

FOR TITLE I DESIGN

PROJECT: W-314, TANK FARM RESTORATION AND SAFE OPERATIONS

PREPARED BY: ICF KAISER HANFORD COMPANY

DATE: APRIL 23, 1996

\subsection{SCOPE}

This statement of work addresses the engineering and management activities to be performed by ICF Kaiser Hanford Company in the design of the Tank Farm Restoration and Safe Operations Project. The scope of the upgrades focus on the DST system (AN, AP, AW, AY, and AZ Tank Farms) in the 200 East Area, and also includes the SY Tank Farm in the 200 West Area, the 244-A and 244-S DCRTs, new transfer lines in the 200 East Area, and minor electrical improvements in the SST Tank Farms (A, AX, B, $B X, B Y, C, S, S X, T, T Y, T X$, and U Tank Farms).

Sufficient design will be performed during the Title I phase to firmly fix the project scope and features of the project, and further develop costs and schedules. Title I design will generally include the following:

- Development of P\&ID's and flow diagrams

- Further definition of project design criteria

- Expansion of conceptual design drawings

- Further development of outline specifications

- Identification of long-lead materials/equipment

- Improvement in the accuracy of the cost estimate

- Preparation of the Title I Design Report

\subsection{BASIS}

This engineering statement of work and engineering estimate were prepared using the W-314 Conceptual Design Report (WHC-SD-W314-CDR-001) as a basis.

This engineering statement of work and engineering estimate were prepared considering that the Title I design will be performed by the onsite engineer/constructor.

The schedule to perform the Title I design is as follows:

Start

Complete January 1998 


\subsection{DESIGN ACTIVITIES}

3.1 Civil/Structural/Environmental

AN Tank Farm
- 1 Site Plan Drawing
- 2 Equipment Pads and Shielding Walls Drawings
- 1 Ventilation Equipment Roof Drawing
- 1 Seal Pot Pit Drawing
- 1 Pit Modification and Cover Block Drawing
- Preliminary calculations
Input to the Title I Design Report
- 1 Site Plan Drawing
- $\quad 1$ Pit Modification and Cover Block Drawing
- Input to the Title I Design Report

AP Tank Farm

AW Tank Farm
- 1 Site Plan Drawing
- Input to the Titie I Design Report
AY Tank Farm
- 1 Site Plan Drawing
Input to the Title I Design Report
AZ Tank Farm
- 1 Site Plan Drawing
- 1 Pit Modification and Cover Block Drawing
SY Tank Farm
Input to the Title I Design Report

\author{
- 1 Site Plan Drawing \\ - Input to the Title I Design Report
}
244-A DCRT
- 1 Site Plan Drawing
- 1 Equipment Pads and Shielding Wall Drawing
- 1 Ventilation Equipment Roof Drawing
- Preliminary calculations
244-S DCRT
Input to the Title I Design Report
- 1 Site Plan Drawing
200 East/West Areas
Input to the Title I Design Report
- 4 Site Plan Drawings
- 1 Pit Modification and Cover Block Drawing
- Input to the Title I Design Report

\subsection{Piping}

AN Tank Farm

- 3 Process Flow Diagrams

- 8 P\&ID's

- 6 Plan/Arrangement Drawings

- 2 Section/Detail Drawings

- Input to the Title I Design Report 
WHC-SD-W314-CDR-001, Rev. 0

Page 37 of 84

AP Tank Farm

- 1 Process Flow Diagram

- 5 P\&ID's

- 2 Plan/Arrangement Drawings

- 1 Section/Detail Drawing

AW Tank Farm Input to the Titie I Design Report

- 1 Process Flow Diagram

- 4 P\&ID's

- 2 Plan/Arrangement Drawings

- 1 Section/Detail Drawing

AY Tank Farm

Input to the Title I Design Report

- 2 P\&ID's

- 1 Plan/Arrangement Drawing

- 1 Section/Detail Drawing

AZ Tank Farm

Input to the Title I Design Report

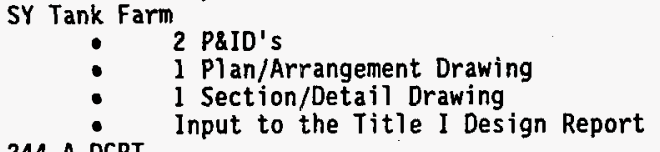

Farm

244-A DCRT

3 P\&ID's

- $\quad 2$ Plan/Arrangement Drawing

- Input to the Title I Design Report

- 1 P\&ID

- 1 Plan/Arrangement Drawing

- Input to the Title I Design Report

244-S DCRT

- 1 P\&ID

- 1 Plan/Arrangement Drawing

- Input to the Title I Design Report

200E/200W Infrastructure

- 4 P\&ID's

- $\quad 12$ Plan/Arrangement Drawings

- 2 Section/Detail Drawings

- Input to the Title I Design Report

\subsection{HVAC}

AN Tank Farm

- 1 Primary Flow Diagram

- 1 Annulus Flow Diagram

- 1 Equipment Arrangement Drawing

- Preliminary calculations

- Input to the Title I Design Report 


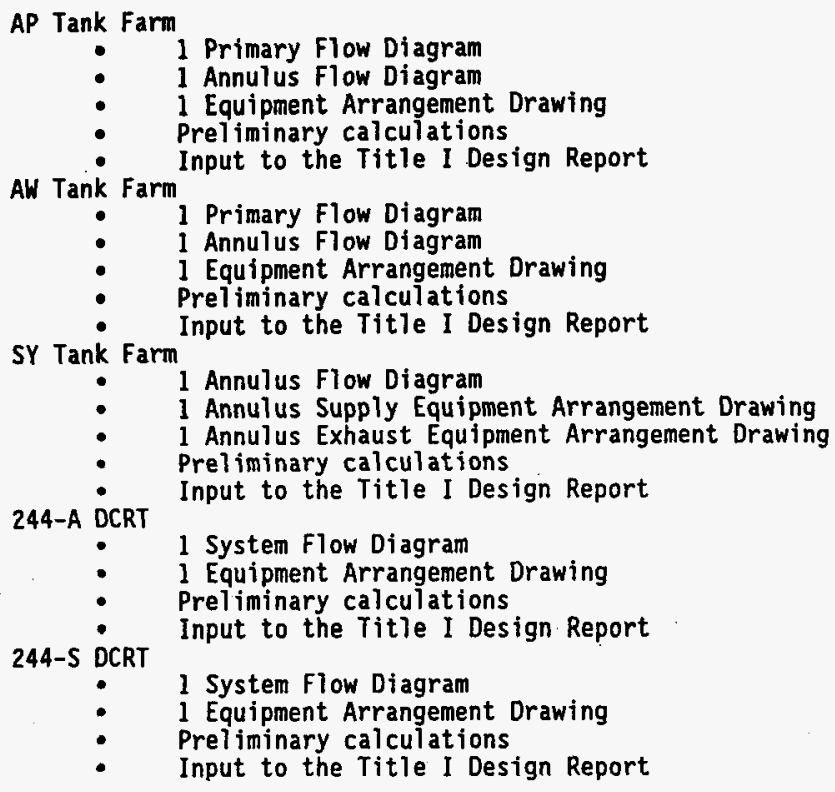

- 1 Primary Flow Diagram

- 1 Annulus Flow Diagram

- $\quad 1$ Equipment Arrangement Drawing

- Preliminary calculations

- Input to the Title I Design Report

SY Tank Farm

- 1 Annulus Flow Diagram

- 1 Annulus Supply Equipment Arrangement Drawing

- 1 Annulus Exhaust Equipment Arrangement Drawing

- Preliminary calculations

- Input to the Title I Design Report

244-A DCRT

- 1 System Flow Diagram

- 1 Equipment Arrangement Drawing

- Preliminary calculations

- Input to the Title I Design Report

244-S DCRT
- 1 System Flow Diagram
- 1 Equipment Arrangement Drawing
- Preliminary calculations
- Input to the Title I Design Report

\subsection{Instrumentation}

AN Tank Farm

- 4 Primary Ventilation Exhaust Instrument Engineering Flow Diagrams

- Input to the Title I Design Report

AP Tank Farm

- 4 Primary Ventilation Exhaust Instrument Engineering Flow Diagrams

Aw Tank Farm Input to the Title I Design Report

- 4 Primary Ventilation Exhaust Instrument Engineering Flow Diagrams

AY Tank Farm

Input to the Titie I Design Report

AZ Tank Farm

Input to the Title I Design Report

SY Tank Farm

Input to the Title I Design Report

- 1 Annulus Air Inlet Instrument Engineering Flow Diagram

- 3 Annulus Air Exhaust Instrument Engineering Flow Diagrams 
- Input to the Title I Design Report

244-A DCRT

- 3 Ventilation Inlet Air and Exhaust Air Instrument Engineering Flow Diagrams

- Input to the Title I Design Report

244-S DCRT

3 Ventilation Inlet Air and Exhaust Air Instrument

Engineering Flow Diagrams

Input to the Title I Design Report

200E/200W Infrastructure

- Input to the Title I Design Report

\subsection{Electrical}

AN Tank Farm

- 1 One-Line Diagram

- 1 Electrical/Instrumentation Site Plan Drawing

- I Building Modifications/Equipment Location Drawing

- l Panelboard Schedule Drawing

- Input to the Title I Design Report

AP Tank Farm

- 1 One-Line Diagram

- 1 Electrical/Instrumentation Site Plan Drawing

- 1 Building Modifications/Equipment Location Drawing

- 1 Panelboard Schedule Drawing

- Input to the Title I Design Report

AW Tank Farm

- 1 One-Line Diagram

- I Electrical/Instrumentation Site Plan Drawing

- 1 Building Modifications/Equipment Location Drawing

- 1 Panelboard Schedule Drawing

- Input to the Title I Design Report

AY Tank Farm

- 1 One-Line Diagram

- 1 Electrical/Instrumentation Site Plan Drawing

- 1 Building Modifications/Equipment Location Drawing

- 1 Panelboard Schedule Drawing

AZ Tank Farm

Input to the Title I Design Report

- 2 One-Line Diagrams

- 1 Electrical/Instrumentation Site Plan Drawing

- 1 Building Modifications/Equipment Location Drawing

- 1 Panelboard Schedule Drawing

SY Tank Farm

Input to the Title I Design Report

\footnotetext{
- 1 One-Line Diagram

- $\quad 1$ Electrical/Instrumentation Site P1an Drawing

- 1 Building Modifications/Equipment Location Drawing

- 1 Panelboard Schedule Drawing

- Input to the Title I Design Report
} 


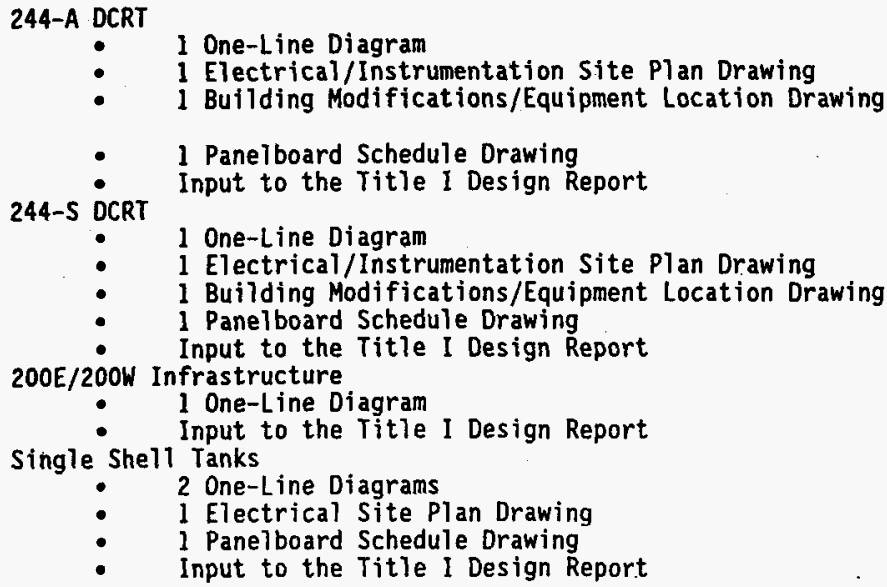

\subsection{Systems Engineering Activities}

- Continuation of requirements development, starting from specifications generated during conceptual design and ending with lower-level specifications suitable for detailed design.

- Continuation of architectural development, starting with the Baseline System Description (BSD) generated during conceptual design and completing with a BSD to the level of the detailed design specifications.

- Continuation of management interfaces defined during conceptual design and updating interface documentation as changes are generated.

- Continuation of logistics support analysis to develop the system support and maintenance requirements; and ensure system supportability in a cost-effective manner.

- Continuation of training requirements analysis, evaluating need for specialized training equipment and programs.

- Continuation of installation requirements analysis, developing an installation concept, equipment needs, costs and specifications for specialized installation equipment.

- Continuation of test requirements analysis and system verification in accordance with the Test and Evaluation Plan.

- Continuation of D\&D analysis, developing concepts and feeding these back into design. 


\subsection{Pre-Title II Studies}

- Perform engineering studies on items that are identified upon completion of the conceptual design which will facilitate the start of Title II design.

\subsection{Title I Design Support}

The disciplines listed above will require other engineering, supervision, and administration support as listed below:

- ENVIRONMENTAL ENGINEERING (22)

a. Review and approve the design documents for compliance with appropriate environmental regulatory requirements.

- DESIGN ADMINISTRATION (35)

a. Provide design supervision and interdiscipline coordination.

b. Make engineering personnel assignments (DM).

c. Provide discipline technical oversight (DM).

d. Coordinate design basis inputs with the discipline lead engineers (PLE).

e. Plan/coordinate/approve engineering estimates/schedules prepared by the discipline lead engineers (PLE).

f. Ensure the design tasks are completed in accordance with all quality requirements and procedures (PLE).

- PROJECT MANAGEMENT (40)

a. Provide single point interface between ICF KH and WHC.

b. Prepare Engineering Work Plan.

c. Provide daily management of project activities.

d. Ensure the project technical, budget, and schedule objectives are met.

e. Disposition client comments.

f. Hold bi-weekly status meetings with client and prepare meeting minutes.

g. Hold weekly design team meetings.

h. Perform definitive design planning.

i. Develop design and construction schedules.

j. Input to, review and comment on the Title II SOW, estimate and schedules.

- WORD PROCESSING (41)

a. Provide word processing services for Title I Design Report.

- ACCEPTANCE INSPECTION (44)

a. Provide input to the Title I to assure compliance with the appropriate criteria and procedures. 
Page 42 of 84

b. Review and comment on Title I and sketches as required.

- PROJECT CONTROLS (45)

a. Provide a cost and scheduling services for the Title I work.

b. Status Work Plan schedule on monthly basis.

c. Track changes to the Work Plan basis.

d. Develop definitive design and construction schedules.

- COST ESTIMATING (46)

a. Prepare definitive design and construction cost estimate.

- PUBLICATIONS (48)

a. Prepare and issue the Title I Design Report.

b. Prepare outline specifications.

c. Make reproductions and assemble documents.

d. Prepare advance Procurement Specifications.

- $\quad$ SUBCONTRACTS/PROCUREMENT (49)

a. Provide procurement review and input to procurement schedule.

- CONSTRUCTION FORCE ADMINISTRATION (60)

a. Input to construction schedule.

b. Review and comment on cost estimate.

d. Perform constructability review of concept.

- CONSTRUCTION MANAGEMENT ADMINISTRATION (61)

a. Provide input to the advance Procurement Specifications.

- SURVEY (62)

a. Provide survey services to support route planning for

underground piping and conduit.

b. Provide scanning services of valve pits to support valve manifold designs.

- RECORDS MANAGEMENT (65)

a. Maintain project records.

b. Perform transmittals.

\subsection{ASSUMPTIONS}

4.1 The Upgrade Scope Summary Report (provided by WHC) will be the basis for what has to be replaced/upgraded for Project W-314.

4.2 Information that has been or will be developed during the system engineering process will be used to the greatest extent possible. 
4.3 Economies of scale have been employed in this estimate by assuming the tank farm details will be common throughout all the upgrades, which reduces the number of drawings and calculations required.

4.4. Many Title I design activities are common to several farms. A reduction in project scope may not proportionately reduce the engineering cost.

4.5 The estimate assumes the deliverables will only show the upgrades covered under this project and necessary interfaces with existing equipment. There is no allowance for incorporating all existing infrastructure (i.e., as-built drawings).

4.6 The design for the HVAC system will be modular to the extent that special effluent treatment devices (such as absorbers for organics and/or ammonia control) can be easily connected in the future.

4.7 The HVAC design will. assume that upgraded ventilation equipment will be removed with the new equipment located in a nearby area.

4.8 The new primary ventilation equipment will be generic to AN, $A P$, and AW Tank Farms; the capacity may be adjusted to suit each individual farm. The DCRT's require new designs.

4.9 The primary ventilation systems are assumed safety class 2 for confinement and safety class 3 for operation. The annulus ventilation system is assumed safety class 3 . 


\title{
ENGINEERING STATEMENT OF WORK
}

\author{
FOR TITLE II DESIEN
}

\section{PROJECT: $\mathrm{H}-314$, TANK FARM RESTORATION AND SAFE OPERATIONS}

\section{PREPARED BY: ICF KAISER HANFORD COMPANY}

DATE: APRIL 23, 1996

\subsection{SCOPE}

The engineering work performed during Title II will utilize the approved Title I design and design criteria that have been prepared for the project as a design basis. Design performed during the Title II phase will produce drawings and specifications which will be used for procurement and construction activities. Title II design will generally include:

- Completion of design media developed in the Title I design phase

- Development of final drawings and specifications which will be used for procurement and construction

- Development of detailed estimates of construction costs, procurement schedules, construction schedules, methods of performance, and identification of work packages

\subsection{BASIS}

2.1 This engineering statement of work and engineering estimate were prepared using the W-314 Conceptual Design Report (WHC-SD-W314-CDR-001) as a basis.

2.2 This engineering statement of work and engineering estimate were prepared considering that the Title II design will be performed by the onsite engineer/constructor.

2.3 The schedule to perform the Titie II design is as follows:

\begin{tabular}{|c|c|c|}
\hline $\begin{array}{l}\text { AN Tank Farm } \\
\text { AP Tank Farm } \\
\text { AW Tank Farm } \\
\text { AY Tank Farm } \\
\text { AZ Tank Farm } \\
\text { SY Tank Farm }\end{array}$ & $\begin{array}{l}\text { Start } \\
\text { Complete } \\
\text { Start } \\
\text { Complete } \\
\text { Start } \\
\text { Complete } \\
\text { Start } \\
\text { Complete } \\
\text { Start } \\
\text { Complete } \\
\text { Start } \\
\text { Complete }\end{array}$ & $\begin{array}{l}\text { March } 2001 \\
\text { March } 2002 \\
\text { August } 2001 \\
\text { August } 2002 \\
\text { April } 1998 \\
\text { May } 1999 \\
\text { March } 2000 \\
\text { March } 2001 \\
\text { March } 2000 \\
\text { March } 2001 \\
\text { May 1999 } \\
\text { May 2000 }\end{array}$ \\
\hline
\end{tabular}


WHC-SD-W314-CDR-001, Rev. 0

Page 45 of 84

\begin{tabular}{|c|c|c|}
\hline $\begin{array}{l}\text { 244-A DCRT } \\
244-S \text { DCRT } \\
200 E / 200 \mathrm{~W} \\
\text { SST }\end{array}$ & $\begin{array}{l}\text { Start } \\
\text { Complete } \\
\text { Start } \\
\text { Complete } \\
\text { Start } \\
\text { Complete } \\
\text { Start } \\
\text { Complete }\end{array}$ & $\begin{array}{l}\text { March } 1999 \\
\text { October } 1999 \\
\text { September } 1998 \\
\text { Narch } 1999 \\
\text { April } 1998 \\
\text { March } 1999 \\
\text { April 1998 } \\
\text { October } 1998\end{array}$ \\
\hline
\end{tabular}

\subsection{DESIGN ACTIVITIES (AN TANK FARM)}

\subsection{Civil/Structural/Environmental}

3.1.1 Drawings

- 1 Drawing List

- I Civil Site Plan

- 1 Equipment Pads and Shielding Walls - drawing will give orientation, various size and thickness factors for concrete pads, shielding walls, and foundations for the ventilation units

- 2 Shielding Wall Sections and Details - expansion of detail of previous drawing

- I Ventilation Equipment Roof - drawing will provide framing orientation and size of members for removable roof and stack support

- 1 Roof Frame Details - expansion of details from previous drawing

- 1 Drain Pit - drawing will provide detail dimensions of the drain pit and related cover blocks

- 2 Drain Pit Sections and Details - expansion of detail from previous drawing

- 1 Pit Modifications and Cover Blocks - drawing will depict new cover blocks for 2 pits

\section{$3: 1.2$ Specifications}

- Construction Specification - Prepare the following sections: Demolition; Asphaltic Concrete Paving; Fencing; Metal Fabrications; Earthwork; Concrete; Structural Steel; and Special Protective Coating.

- Procurement Specification - Provide input to the HVAC ventilation equipment procurement specification

\subsubsection{Calculations}

- Shielding wall structural analysis; shielding wall connection/detail structural analysis; ventilation equipment roof structural analysis; ventilation equipment roof connection detail structural analysis; drain pit structural analysis; cover block structura? analysis; equipment support pad structural anaiysis; 


\subsection{Piping}

stack and related support structural analysis; pit modification structural analysis; and instrument rack structural analysis; process flow diagrams.

\subsubsection{Drawings}

- 3 Piping Plans - locations of piping provided for HVAC drains and seal pot drains

- 2 Piping Sections - section view of previous drawing

- 2 Piping Support - support details for new piping

- 4 Pit Arrangements - new jumper arrangements of pits receiving new valve manifolds

- 7 Pit Sections and Details - sections and details of previous drawings

- 27 Jumper Assemblies and Details - individual assemblies of each new jumper (spools, valves, flow elements, remote connectors, etc.)

- 1 Cathodic Protection Plan - plan view of new piping locating elements requiring modification to the existing cathodic protection system

- 2 Seal Pot Plan and Details - details of new seal pot for use in procurement specification

- 2 Heat Trace Plans and Details - location and details of any required heat trace added to equipment

- 1 Thermocouple Tree - outline and details of new thermocouple tree

- 1 Service/Utilities Plans and Details - location and details of service piping required for tie-in to the new seal pot and HVAC system

\subsubsection{Specifications}

- Construction Specification - Prepare the chemical process piping system section; develop pipe codes which outline service conditions, size and thickness values, material requirements, fitting classifications, gasket materials, and valve selections for all new piping systems

- Procurement Specification - Prepare the Seal Pot Specification, which will include drawings, design details, quality requirements, and fabrication requirements

\subsubsection{Calculations}

- 3 pipe stress analysis; 2 pipe support analysis;

1 seal pot design analysis; 4 shielding analysis;

1 in-tank component analysis 


\subsection{HVAC}

\subsubsection{Drawings}

- 1 Primary System Flow Diagram - a schematic of the ventilation system design, showing individual components, simplified instrumentation, airflows, and system operation.

- 5 Primary Exhaust Equipment Elevation, Plan, Sections and Details - the physical equipment arrangement, to scale, and include enough detail for a fabricator to build the equipment.

\subsubsection{Specifications}

- Construction Specification - Prepare the heating, ventilation, and air conditioning section

- Procurement Specification - Prepare a specification for the ventilation equipment

\subsubsection{Calculations}

- Primary system airflows; pressure drops; heat and mass transfer; demister; energy conservation; shielding analysis.

\subsection{Instrumentation}

\subsubsection{Drawings}

- 1 General Plan - depict the general equipment/ instrumentation locations

- $\quad 2$ Plan and Elevation - for installation of PLC/MMI and support equipment in existing instrument building

- 3 Tank Primary Waste Temperature Assembly - these drawings will be included in the procurement specification

- 1 TMACS Assembly - TMACS cabinet modification to allow parallel TFLAN inputs

- 1 Temperature Tree Installation - Temperature tree and RTD signal box installation in a riser

- $\quad 1$ Instrument Cabinet Demolition - existing cabinet located next to leak detection pit

- 1 Instrument Cabinet Assembly - cabinet to house vapor pressure transmitters, leak detection pit gamma radiation monitor, heater

- I Vaive Positioning Indication - modify existing leak detector relay/alarm box to show local indication of valve positions

- 2 Leak Detection Assembly - typical drawing showing installation of floor mounted detectors. Drawings will be used for procurement specification 
- 1 Tank Annulus Liquid Presence Detector Installation installation of detector in riser

- 1 Tank Annulus Exhaust Air Leak Detector modification of existing cabinet for new CAM

- 1 Leak Detection Pit/Gamma Radiation Monitor installation of leak detector in pit and sump and gamma probe in radiation well

- 6 Process Pit Leak Detection Installation installation of leak detectors in central pump pit, annulus pump pit, valve pits, service pit/flush pit, supernate receiver pit, condensate receiver pit

- I Raw Water Flow Meter Installation - installation of flow meter in raw water line in service pit.

- 1 Waste Level High Installation - installation of high level instrument in a riser

- 1 Clean Out Box Installation - installation of leak detectors, connectors, junction box

- 2 Pipeline Leak Detector - pipe encasement leak detectors on risers, and pipe encasement leak detectors on drain lines inside a pit

- l Seal Pot Instrumentation Installation - installation of level, pit and pipe leak detection instruments in seal pot

- 1 Stack Monitor Installation - show necessary detail to install the GEMS specified stack monitor

- 1 TFLAN I/0 Box Assembly - typical I/0 box with enclosure, heater, terminal strip

- 24 Loop Diagrams - loop diagrams showing connections from sensors to display devices for 24 loops

- 10 HVAC Logic Diagrams - loop diagrams showing connections from sensors to display devices for 10 HVAC loops

- $\quad 77$ Master Pump Shutdown Logic Diagrams - logic diagrams showing logic configuration for selectable permissives from MPS for each of the 7 tank pumps

- $\quad 12$ AN Tank Farm Master Pump Shutdown Logic Diagrams logic diagrams for AN Tank Farm permissive

- 33 Instrument Lists - list will reference the appropriate drawing, specification, and $1 / 0$ point number

\subsubsection{Specifications}

- Construction Specification - Prepare the instrumentation sections

- Procurement Specifications - Prepare 5 specifications as follows: General (instruments/equipment); Stack Monitor: Programmable Logic Controller, Man-Machine Interface, I/0 Boxes; Temperature Tree; Leak Detector. Provide input to the HVAC ventilation equipment, and the piping seal pot procurement specifications. 
Page 49 of 84

\subsection{Electrical}

\subsubsection{Drawings}

- 1 One-Line Diagram - ampere, voltage, phase, and power ratings of electrical equipment/devices; feeder conductor sizes and provisions required for backup power to upgrade the primary vent system

- 3 Elementary Diagrams - motor control center schematics showing control/interlocking devices for motors, heaters, and dampers; ladder diagrams for annunciator alarms and master pump shutdown circuit

- $\quad 1$ Power/Control/Instrumentation Conduit Layout Plan locations of electrical and instrumentation equipment/devices as well as conduit layout

- 2 Plan, Sections, and Details - enlarged plan of primary vent system and associated details

- 1 Panelboard Schedule - panelboard voltage, ampere, phase, and power ratings; number and type of circuit breakers

- 2 Wire Run Lists - conduit and wire/cable numbering system and associated routing

- 2 Cathodic Protection Plan and Details - location of existing rectifier, new cathodic protection equipment, and devices and conduit layout

\subsubsection{Specifications}

- Construction Specification - Prepare the service and distribution and cathodic protection sections

- Acceptance Test Procedure - Cathodic Protection

\subsubsection{Caiculations}

- 1 Load analysis and voltage drop; 1 cathodic protection

\subsection{DESIGN ACTIVITIES (AP TANK FARM)}

\subsection{Civil/Structural/Environmenta]}

\subsubsection{Drawings}

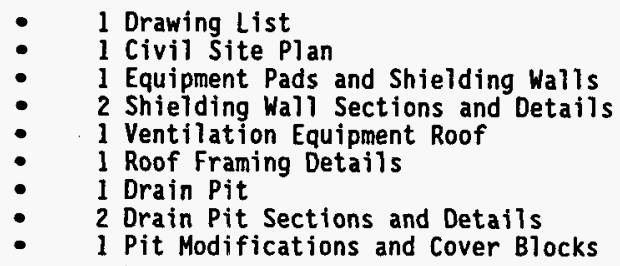




\subsubsection{Specifications}

- Construction Specification - Prepare the following sections: Demolition; Asphaltic Concrete Paving; Fencing; Metal Fabrications; Earthwork; Concrete; Structural Steel; and Special Protective Coating.

- Procurement Specification - provide input to the HVAC ventilation procurement specification

4.1.3 Calculations

- Shielding wall; vent equipment roof; drain pit; cover block; equipment support pad; stack; pit modification; instrument rack; process flow diagrams

\subsection{Piping}

4.2.1 Drawings

- 3 Piping Plans

- 2 Piping Sections

- 2 Piping Support

- 3 Pit Arrangements

- 6 Pit Sections and Details

- 13 Jumper Assemblies and Details

- 1 Cathodic Protection Plan

- 2 Seal Pot and Details

- 2 Heat Trace Plans and Details

- 1 Thermocouple Tree

- 1 Service/Utilities Plan and Details

\subsubsection{Specifications}

- Construction Specification - prepare the chemical process piping section and associated pipe codes

- Procurement Specification - Seal Pot

\subsubsection{Calculations}

- 3 pipe stress analysis; 1 pipe support analysis;

1 seal pot design analysis; 2 shielding analysis;

1 in-tank component analysis

\subsection{HVAC}

\subsubsection{Drawings}

- 1 Primary System Flow Diagram

- 5 Primary Exhaust Equipment Elevation, Plan, Sections and Details 


\subsubsection{Specifications}

- Construction Specification - prepare the HVAC sections

- Procurement Specification - prepare the ventilation equipment specification

\subsubsection{Calculations}

- Primary system air flows; pressure drops; heat and mass transfer; demister; energy conservation; shielding analysis

\subsection{Instrumentation}

\subsubsection{Drawings}

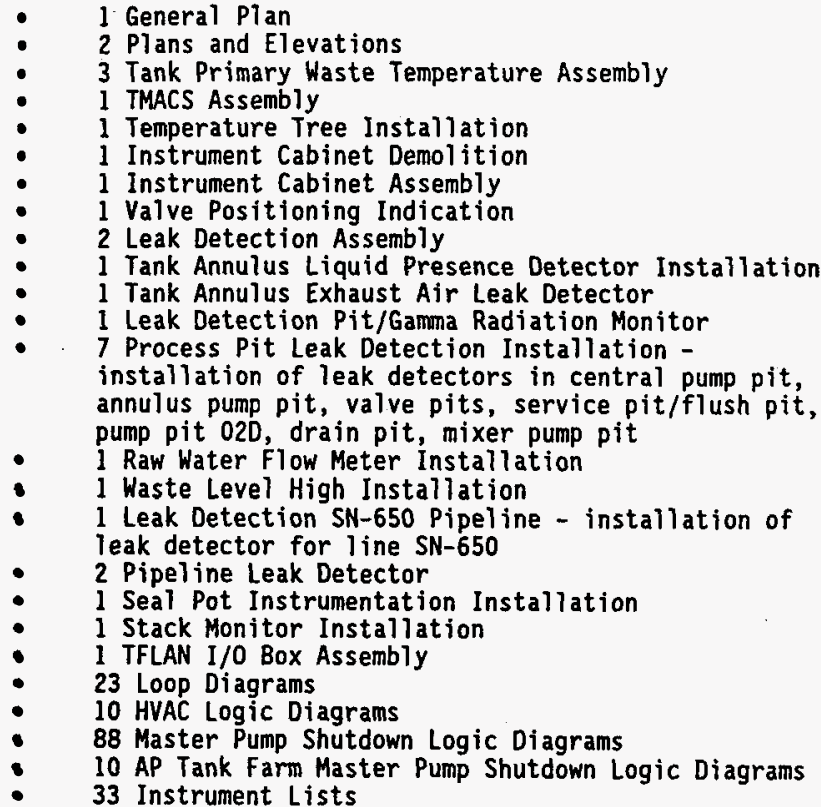

\subsubsection{Specifications}

- Construction Specification - prepare the instrumentation sections

- Procurement Specifications - Prepare 5 specifications as follows: General (equipment/instruments); Stack 
WHC-SD-W314-CDR-001, Rev. 0

Page 52 of 84

Monitor; PLC/MMI/I/O Boxes; Temperature Tree; Leak Detector. Provide input to the ventilation equipment specification.

\subsection{Electrical}

\subsubsection{Drawings}

- 1 One-Line Diagram

- 3 Elementary Di agrams

- 1 Power/Control/Instrumentation Conduit Layout Plan

- 2 Plan, Sections, and Details

- 1 Panelboard Schedule

- 2 Wire Run Lists

- 2 Cathodic Protection Plan and Details

\subsubsection{Specifications}

- Construction Specification - Prepare the service and distribution and cathodic protection sections

- Acceptance Test Procedure - Cathodic Protection

\subsubsection{Calculations}

- 1 load analysis and voltage drop; 1 cathodic protection

\subsection{DESIGN ACTIVITIES (AH TANK FARM)}

\subsection{Civil/Structural/Environmenta]}

5.1.1 Drawings

- 1 Drawing List

- 1 Site Plan

- 1 Equipment Pads and Shielding Wall

- 2 Shielding Wall Sections and Details

- 1 Ventilation Equipment Roof

- 1 Roof Framing Details

- 1 Drain Pit

- 2 Drain Pit Sections and Details

- 1 Pit Modification and Cover Block

\subsubsection{Specifications}

- Construction Specification - prepare the following sections: Demolition; Asphaltic Concrete Paving; Fencing; Metal Fabrications; Earthwork; Concrete; Structural Steel; Special Protective Coating

- Procurement Specification - Input to the ventilation equipment procurement specification 


\subsubsection{Calculations}

- Shielding wall; vent equipment roof; drain pit; cover block; equipment support pad; stack; pit modification; instrument rack; process flow diagrams

\subsection{Piping}

5.2.1 Drawings
- 3 Piping Plans
- 2 Piping Sections
- 1 Piping Support
- 4 Pit Arrangements
- 6 Pit Sections and Details
- 13 Jumper Assemblies and Details
- 1 Cathodic Protection Plan
- 2 Seal Pot and Details
- 2 Heat Trace Plans and Details
- 1 Thermocouple Tree
- 1 Service/Utilities Plans and Details

\subsubsection{Specifications}

- Construction Specification - prepare the chemical process piping section and associated pipe codes

- Procurement Specification - Seal Pot

\subsubsection{Calculations}

- 3 pipe stress analysis; 2 pipe support analysis;

1 seal pot design analysis; 4 shielding analysis;

1 in-tank component analysis

\subsection{HVAC}

\subsubsection{Drawings}

- 1 Primary System Flow Diagram

- 5 Primary Exhaust Equiipment Plan, Sections and Details

\subsubsection{Specifications}

- Construction Specification - prepare the HVAC sections

- Procurement Specification - ventilation equipment

\subsubsection{Calculations}

- Primary system air flows; pressure drops; heat and mass transfer; demister; energy conservation; shielding analysis 


\subsection{Instrumentation}

\subsubsection{Drawings}

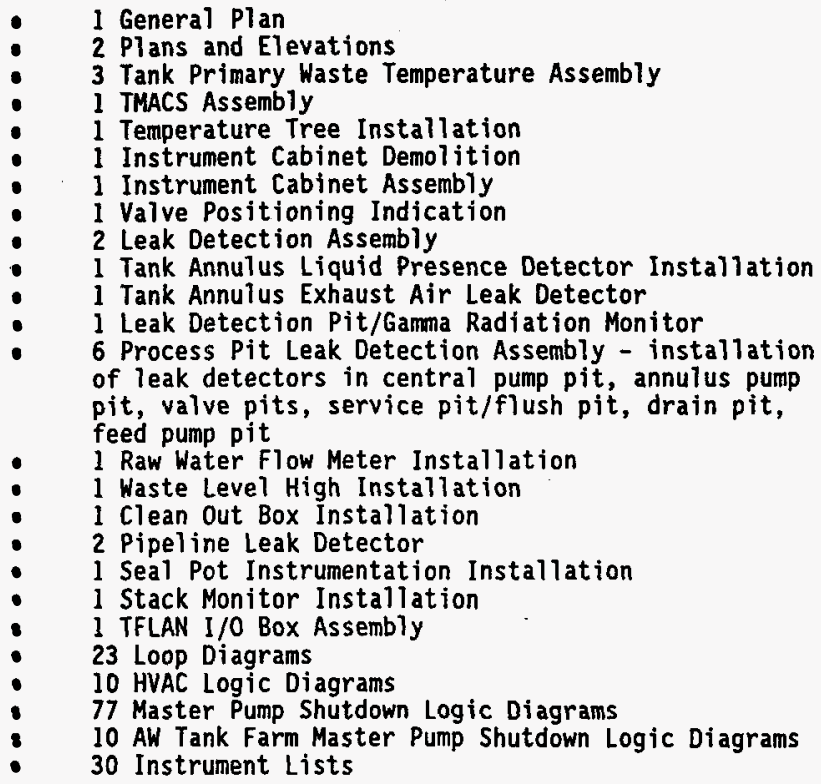

\subsubsection{Specifications}

- Construction Specification - prepare the instrumentation sections

- Procurement Specifications - Prepare 5 specifications: General (equipment/instruments); Stack Monitor; PLC/MMI/I/O Boxes; Temperature Tree; Leak Detector. Provide input to the ventilation equipment specification.

\subsection{ETectrical}

\subsubsection{Drawings}

- 1 One-Line Diagram

- 3 Elementary Diagram

- I Power/Control/Instrumentation Conduit Layout Plan

- 2 PI an, Sections, and Details

- 1 Pahelboard Schedule 
WHC-SD-W314-CDR-001, Rev. 0

Page 55 of 84

- 2 Wire Run Lists

- 2 Cathodic Protection Plan and Details

5.5.2 Specifications

- Construction Specification - Prepare the service and distribution and cathodic protection sections

- Acceptance Test Procedure - Cathodic Protection

\subsubsection{Calculations}

- 1 load analysis and voltage drop; 1 cathodic protection.

\subsection{DESIGN ACTIVITIES (AY TANK FARN)}

6.1 Civil/Structural/Environmental

6.1.1 Drawings

- 1 Drawing List

- 1 Site Plan

6.1.2 Specifications

- Construction Specification - Prepare the following sections: Demolition; Asphaltic Concrete Paving; Fencing; Metal Fabrications; Earthwork; Concrete; Structural Steel; Special Protective Coating.

\subsubsection{Calculations}

- Pit modification structural analysis; instrument rack structural analysis.

6.2 Piping

\subsubsection{Drawings}

- 1 Piping Pian

- 1 Piping Section

- 1 Piping Support

- 1 Pit Arrangement.

- 3 Pit Sections and Details

- 5 Jumper Assemblies and Details

- 1 Cathodic Protection Plan

- 1 Thermocouple Tree

- 1 Service/Utilities Plan and Details 


\subsubsection{Specifications}

- Construction Specification. - prepare the chemical process piping section and associated pipe codes

\subsubsection{Calculations}

- $\quad 2$ pipe stress analysis; 2 pipe support analysis;

1 seal pot design analysis; 4 shielding analysis;

1 in-tank component analysis

\subsection{Instrumentation}

\subsubsection{Drawings}

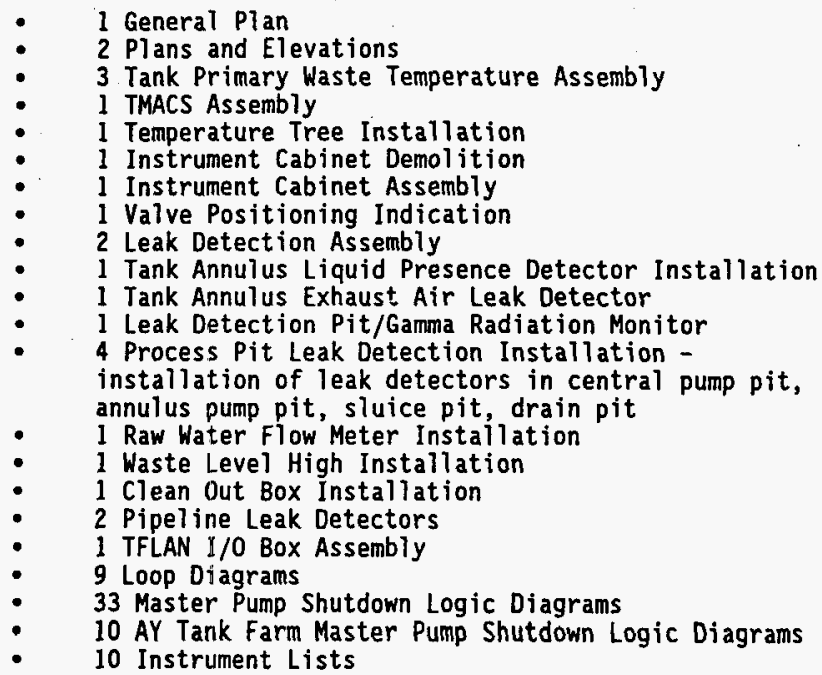

\subsubsection{Specifications}

- Construction Specification - Prepare the instrumentation sections

- Procurement Specifications - Prepare 4 specifications as follows: General (instruments/equipment); Programmable Logic Controller, Man Machine Interface, 1/0 Boxes; Temperature Tree; Leak Detector. 


\subsection{Electrical}

\subsubsection{Drawings}

- 1 One-Line Diagram - shows the new motor control center complete with feeder circuit breakers, combination starters, and devices to replace the existing motor control center; will also show existing loads and the front elevation of the motor control center

- 3 Elementary Diagrams

- 1 Power/Control/Instrumentation Conduit Layout Plan

- 2 Plan, Sections, and Details

- 1 Panelboard Schedule

- 2 Wire Run Lists

- 2 Cathodic Protection Plan and Detajls

\subsubsection{Specifications}

- Construction Specification - Prepare the service and distribution and cathodic protection sections

- Acceptance Test Procedure - Cathodic Protection

\subsubsection{Calculations}

- 1 load analysis and voltage drop; 1 cathodic protection

\subsection{DESIGN ACTIVITIES (AZ TANK FARM)}

\subsection{Civil/Structural/Environmental}

\subsubsection{Drawings}

- 1 Drawing List

- I Pit Modification and Cover Block

\subsubsection{Specifications}

- Construction Specification - Prepare the following sections: Demolition; Asphaltic Concrete Paving; Fencing; Metal Fabrications; Earthwork; Concrete; Structural Steel; Special Protective Coating.

\subsubsection{Calculations}

- Cover block structural analysis; pit modification structural analysis; instrument rack structural analysis. 


\subsection{Piping}

\subsubsection{Drawings}

$$
\begin{aligned}
& 2 \text { Pit Arrangements } \\
& 2 \text { Pit Sections and Details } \\
& \text { - } 10 \text { Jumper Assemblies and Details } \\
& \quad 1 \text { Thermocouple Tree }
\end{aligned}
$$

\subsubsection{Specifications}

- Construction Specification - prepare the chemical process piping sections and associated pipe codes

\subsubsection{Calculations}

- 1 pipe stress analysis; 1 shielding analysis;

1 in-tank component analysis

\subsection{Instrumentation}

\subsubsection{Drawings}

- 1 General Plan

- 2 Plans and Elevations

- 3 Tank Primary Waste Temperature Assembly

- 1 TMACS Assembiy

- 1 Temperature Tree Installation

- 1 Instrument Cabinet Demolition

- 1 Instrument Cabinet Assembly

- 1 Valve Positioning Indication

- 2 Leak Detection Assembly

- 1 Tank Annulus Liquid Presence Detector Installation

- 1 Tank Annulus Exhaust Air Leak Detector

- 1 Leak Detection Pit/Gamma Radiation Monitor

- 5 Process Pit Leak Detection Installation installation of leak detectors in central pump pit, annulus pump pit, service pit/flush pit, sluice pit, drain pit

- 1 Waste Level High Instailation

- 1 Clean Out Box Installation

- 2 Pipeline Leak Detector

- 1 TFLAN I/O Box Assembly

- 9 Loop Diagrams

- 33 Master Pump Shutdown Logic Diagrams

- 10 AZ Tank Farm Master Pump Shutdown Logic Diagrams

- 10 Instrument Lists

\subsubsection{Specifications}

- Construction Specification - prepare the instrumentation sections 
- Procurement Specifications - Prepare 5 specifications as follows: General (equipment/electrical); Stack Monitor; PLC/MMI/I/O Boxes; Temperature Tree; Leak Detector. Provide input to the ventilation equipment specification.

\subsection{Electrical}

\subsubsection{Drawings}

- 1 One-Line Diagram - will show the new motor control center and their respective loads and front elevation

- 3 Elementary Diagrams

- 1 Power/Control/Instrumentation Conduit Layout Plan

- 2 Plan, Sections, and Details

- 1 Panelboard Schedule

- 2 Wire Run Lists

- 2 Cathodic Protection Plan and Details

7.5.2 Specifications

- Construction Specification - Prepare the service and distribution and cathodic protection sections

- Acceptance Test Procedure - Cathodic Protection

7.5.3 Calculations

- 1 load analysis and voltage drop; 1 cathodic protection

\subsection{DESIGN ACTIVITIES (SY. TANK FARM)}

\subsection{Civi]/Structural/Environmenta]}

8.1.1 Drawings

- $\quad 1$ Drawing List

- 1 Site Plan

- 1 Equipment Pads

- 1 Sections and Detajls

\subsubsection{Specifications}

- Construction Specification - Prepare the following sections: Demolition; Asphaltic Concrete Paving; Fencing; Metal Fabrications; Earthwork; Concrete; Structural Steel; Special Protective Coating.

- Procurement Specification - Input to the ventilation equipment specification 


\subsubsection{Calculations}

- Structural analysis of concrete pads and supports; pit modification structural analysis; instrument rack structural analysis.

\subsection{Piping}

\subsubsection{Drawings}

- 2 Pit Arrangements

- 4 Pit Sections and Details

- 6 Jumper Assembities and Details

- 1 Thermocouple Tree

- 1 Service/Utilities Plan and Details

\subsubsection{Specifications}

- Construction Specification - prepare the chemical process piping section and associated pipe codes

\subsubsection{Calculations}

- I pipe stress analysis; 1 shielding analysis;

1 in-tank component analysis

\subsection{HVAC}

\subsubsection{Drawings}

- 1 Annuius System Flow Diagram - a schematic of the ventilation system design, showing individual components, simplified instrumentation, air flows, and system operation.

- 5 Annulus Exhaust Equipment Elevation, Plan, Sections and Details - the physical equipment arrangement, to scale, and include enough detail for a fabricator to build the equipment.

- 4 Annulus Supply Equipment Plan, Sections and Details - the physical equipment arrangement, to scale, and include enough detail for a fabricator to build the equipment.

\subsubsection{Specifications}

- Construction Specification - prepare the HVAC sections

- Procurement Specification - Ventilation Equipment

\subsubsection{Calculations}

- Annulus system air flows; pressure drops; heat and mass transfer; energy consumption 
WHC-SD-W314-CDR-001, Rev. 0

Page 61 of 84

\subsection{Instrumentation}

8.4.1 Drawings

- 1 General Plan

- 2 Plans and Elevations

- 3 Primary Tank Waste Temperature Assembly

- 1 TMACS Assembly

- 1 Temperature Tree Installation

- 1 Instrument Cabinet Demolition

- 1 Instrument Cabinet Assembly

- 1 Valve Positioning Indication

- 2 Leak Detection Assembly

- 1 Tank Annulus Liquid Presence Detector Installation

- 1 Tank Annulus Exhaust Air Leak Detector

- 1 Leak Detection Pit/Gamma Radiation Monitor

- 6 Process Pit Leak Detection Installation installation of leak detectors in central pump pit, annulus pump pit, valve pits, service pit/flush pit, drain pit \#1, drain pit \#2

- 1 Raw Water Flow Meter Installation

- 1 Waste Level High Installation

- 1 Clean Out Box Installation

- 2 Pipeline Leak Detector

- 1 Seal Pot Instrumentation Installation

- 1 Stack Monitor Installation

- 1 TFLAN I/0 Box Assembly

- 22 Loop Diagrams

- 13 HVAC Logic Diagrams

- $\quad 44$ Master Pump Shutdown Logic Diagrams

- 10 SY Tank Farm Master Pump Shutdown Logic Diagrams

- 17 Instrument Lists

\subsubsection{Specifications}

- Construction Specification - prepare the instrumentation sections

- Procurement Specifications - prepare 5 specifications as follows: General (equipment/instruments); Stack Monitor; PLC/MMI/I/0 Boxes; Temperature Tree; Leak Detector. Input to the Ventilation Equipment Specification.

\subsection{Electrical}

\subsubsection{Drawings}

- 1 One-Line Diagram - will show existing ventilation equipment power panel which will feed the load of the new primary ventilation system and the existing loads fed by the panel

- 3 Elementary Diagrams 
- 1 Power/Control/Instrumentation Conduit Layout Plan

- 2 Plan, Sections, and Details

- 1 Paneiboard Schedule

- 2 Wire Run Lists

8.5.2 Specifications

- Construction Specification - Prepare the service and distribution section

\title{
8.5.3 Calculations
}

1 load analysis and voltage drop

\subsection{DESIGN ACTIVITIES (244-A DCRT)}

\subsection{Civil/Structural/Environmental}

\subsubsection{Drawings}

\author{
- 1 Drawing List \\ - 1 Site Plan. \\ - $\quad 1$ Equipment Pads and Shielding Walls \\ - 2 Shielding Wall Sections and Details \\ - l Ventilation Equipment Roof \\ - 1 Roof Framing Details
}

9.1.2 Specifications

- Construction Specification - prepare the following sections: demolition; asphaltic concrete paving; fencing; metal fabrications; earthwork; concrete; structural steel; special protective coating.

- Procurement Specification - input to the ventilation equipment specification

\subsubsection{Calculations}

- Shielding wall; vent equipment roof; stack; pit modification; instrument rack; process flow diagram

\subsection{HVAC}

\subsubsection{Drawings}

- 1 Ventilation System Flow Diagram - a schematic of the ventilation system design, showing individual components, simplified instrumentation, airflows, and system operation.

- 5 Equipment Arrangement Elevation, Plan, Sections and Details - the physical equipment arrangement, to 
scale, and include enough detail for a fabricator to build the equipment.

- 1 Equipment Schedule - a list of equipment

\subsubsection{Specifications}

- Construction Specification - prepare the HVAC section

\subsubsection{Calculations}

- Air flows; pressure drops; heat and mass transfer; shielding analysis.

\subsection{Instrumentation}

9.4.1 Drawings

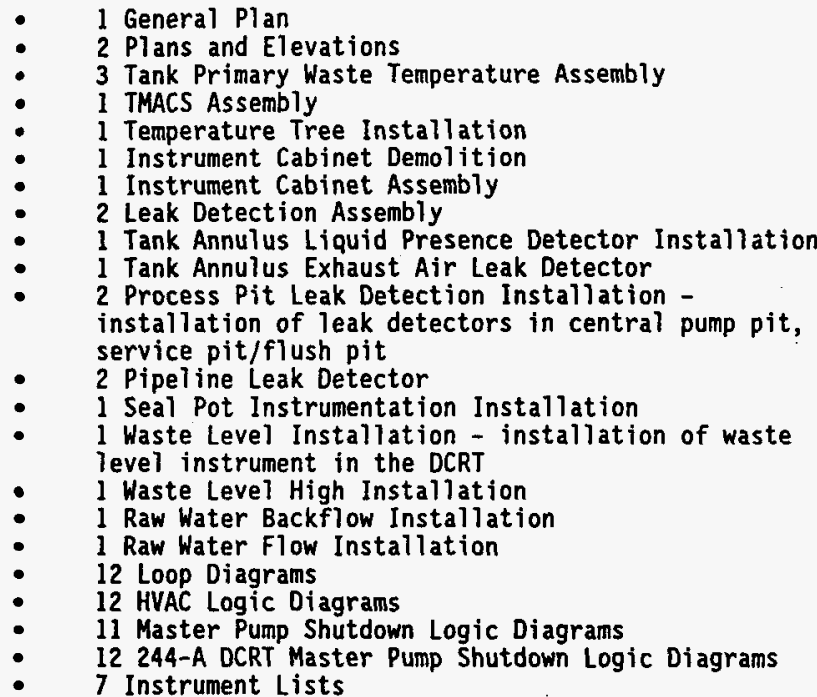

\subsubsection{Specifications}

- Construction Specification - prepare the instrumentation sections

- Procurement Specifications - prepare 4 specifications as follows: General (equipment/instrument); PLC/MMI/I/O Boxes; Temperature Tree; Leak Detector. Provide input to the ventilation equipment specification. 
WHC-SD-W314-CDR-001, Rev. 0

Page 64 of 84

\subsection{Electrical}

\subsubsection{Drawings}

- One-Line Diagram - will show the new panelboard that will feed the new vent system; the loads of the existing power distribution center which will be replaced by the new panelboard; schedule of the new panelboard

- 3 Elementary Diagrams

- 1 Power/Control/Instrumentation Conduit Layout Plan

- 2 Plan, Sections, and Details

- 1 Paneíboard Schedule

- 2 Wire Run Lists

\subsubsection{Specifications}

- Construction Specification - prepare the service and distribution section

\subsubsection{Calculations}

- 1 load analysis and voltage drop

\subsection{DESIGN ACTIVITIES (244-S DCRT)}

\subsection{Civil/Structural/Environmenta]}

10.1.1. Drawings

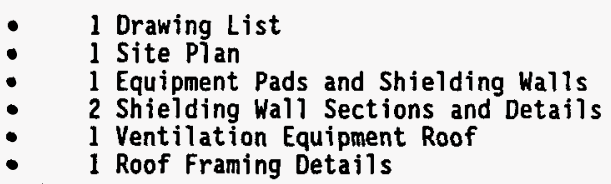

10.1.2 Specifications

- Construction Specification - prepare the following sections: demolition; asphaltic concrete paving; fencing; metal fabrications; concrete; earthwork; structural steel; special protective coating.

- Procurement Specification - provide input to the ventilation equipment specification

10.1.3 Calculations

- Shielding wall; vent equipment roof; stack; pit modification; instrument rack; process flow diagrams 
WHC-SD-W314-CDR-001, Rev. 0

Page 65 of 84

10.3 HVAC

10.3.1 Drawings

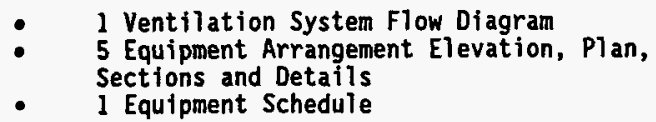

10.3.2 Specifications

- Construction Specification - prepare the HVAC sections

10.3.3 Calculations

- Air flows; pressure drops; heat and mass transfer; shielding analysis

10.4. Instrumentation

10.4.1 Drawings

- 1 General Plan

- 2 Plans and Elevations

- 3 Tank Primary Waste Temperature Assembly

- 1 TMACS Assembly

- 1 Temperature Tree Installation

- 1 Instrument Cabinet Demolition

- 1 Instrument Cabinet Assembly

- 2 Leak Detection Assembly

- 1 Tank Annulus Liquid Presence Detector Installation

- 1 Tank Annulus Exhaust Air Leak Detector

- 2 Process Pit Leak Detection Assembiy installation of leak detectors in central pump pit, service pit/flush pit

- 2 Pipeline Leak Detector

- 1 Seal Pot Installation

- 1 Waste Level Installation

- 1 Waste Level High Installation

- 1 Raw Water Backflow Installation

- 1 Raw Water Flow Installation

- 12 Loop Diagrams

- 12 HVAC Logic Diagrams

- $\quad 11$ Master Pump Shutdown Logic Diagrams

- 12 244-S DCRT Master Pump Shutdown Logic Diagrams

- 7 Instrument Lists 
10.4.2 Specifications

- Construction Specification - prepare the instrumentation sections

- Procurement Specifications - prepare 4 specifications as follows: General (equipment/instrument); PLC/MMI/I/O Boxes; Temperature Tree; Leak Detection. Provide input to the ventilation equipment specification.

10.5 Electrical

10.5.1 Drawings

- 1 One-Line Diagram - will show the new pad mounted transformer, lightning arresters, and fused cutouts connected to the existing $13.8 \mathrm{kV}$ overhead line; existing service distribution (panelboard A) that feeds the new vent system

- 3 Elementary Diagrams

- 1 Power/Control/Instrumentation Conduit Layout Plan

- 2 Plan, Sections, and Details - will show pole line and hardware connection to the existing 13.8kV line, metering, and the pad mounted transformer

- 1 Panelboard Schedule

- 2 Wire Run Lists

10.5.2 Specifications

- Construction Specification - prepare the service and distribution section

10.5.3 Calculations

- 1 load analysis and voitage drop

\subsection{DESIGN ACTIVITIES (200E/200W AREA INFRASTRUCTURE)}

11.1 Civil/Structural/Environmental

11.1 .1 Drawings

- 1 Drawing List

- 4 Site Pians (AN to $A Z$; $A Z$ to $A X ; A$ to $A W ; 244-A$ to $A$ to $A Y$ )

- 3 Plan and Profiles (AN to AZ to AX; 244-A to A;

$A$ to $A Y$ and $A$ to $A W$ )

- 2 Cover Block Modifications and Details 
11.1.2 Specifications

- Construction Specification - prepare the following sections: demolition; asphaltic concrete paving; fencing; metal fabrications; earthwork; concrete; structural steel; special protective coating.

11.1.3 Calculations

- Cover block structural analysis; pit modification structural analysis; instrument rack structural analysis.

11.2 Piping

11.2.1. Drawings

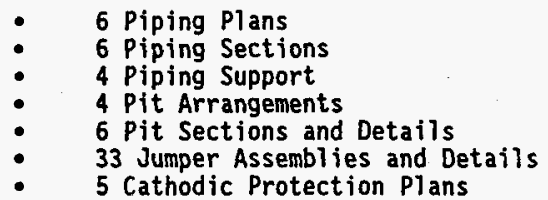

11.2.2 Specifications

- Construction - prepare the chemical process piping section and associated pipe codes

11.2.3 Calculations

- 9 pipe stress analysis; 4 pipe support analysis;

6 shielding analysis

\subsection{Instrumentation}

\subsubsection{Drawings}

- 4 General Plans - A/AX/241-A-271; 242-S/W-211 ICE; 200E TFLAN/TMACS; 200W TFLAN/TMACS

- 5 Programmable Logic Controller/Man Machine Interface Installation - 241-A-271; 242-A; 272-AW; W-211 ICE at SY Tank Farm; WA-278

- I Terminal Box Assembly - for 242-5 demolition

- 1 Valve Positioning Assembly

- 2 Leak Detection Assembiy

- 2 Valve Pit Leak Detection Installation 241-A-A/241-A-B and 241-AX-A/241-AX-B

- 2 Pipeline Leak Detector

- 2 Instrument Building Alarm 
Page 68 of 84

11.4.2 Specifications

- Construction Specification - Prepare the instrumentation sections

- Procurement Specifications - Prepare 3 specifications as follows: General (instruments/equipment); Programmable Logic Controller, Man Machine Interface, I/0 Boxes; Leak Detector.

\subsection{Electrical}

11.5.1 Drawings

- 3 Elementary Diagrams

- 1 Power/Control/Instrumentation Conduit Layout Plan

- 2 Plan, Sections, Details

- 1 Paneiboard Schedule

- 2 Wire Run Lists

- 2 Cathodic Protection Plan and Details

11.5.2 Specifications

- Construction Specification - prepare the service distribution and cathodic protection sections

- Acceptance Test Procedures - Cathodic Protection

11.5.3 Calculations

- 1 cathodic protection

\subsection{DESIGK ACTIVITIES (Single Shell Tanks)}

12.1 Civil/Structural/Environmental

12.1.2 Specifications

- Construction Specification - Prepare the following sections: Earthwork; Concrete.

12.1.3 Calculations

- Concrete foundation structural analysis. 


\subsection{Electrical}

12.5.1 Drawings

- 1 One-Line Diagram - will show the pad mounted transformer, lightning arresters, and fused cutouts connected to the existing $13.8 \mathrm{kV}$ overhead line; new panelboard and associated equipment

- 3 Elementary Diagrams

- 1 Power/Control Conduit Layout Plan

- 2 Plan, Sections, and Details - pole line and hardware connection to the existing $13.8 \mathrm{kV}$ overhead line, metering, and pad mounted transformer

- I Panelboard Schedule

- 2 Wire Run Lists

12.5.2 Specifications

- Construction Specification - prepare the service and distribution section

\subsubsection{Calculations}

- 1 load analysis and voltage drop

\subsection{TITLE II DESIGN SUPPORT}

The disciplines listed above will require other engineering, supervision, and administrative support as listed below:

- ENVIRONMENTAL ENGINEERING (22)

a. Review and approve the design documents for compliance with appropriate environmental regulatory requirements.

- SPECIFICATIONS (32)

a. Prepare Construction and Procurement Specifications

- DESIGN ADMINISTRATION (35)

a. Provide design supervision and interdiscipline coordination.

b. Make engineering personnel assignments (DM).

c. Provide discipl ine technical oversight (DM).

d. Coordinate design basis inputs with the discipline lead engineers (PLE).

e. Ensure the design tasks are completed in accordance with all quality requirements and procedures (PLE). 
Page 70 of 84

- PROJECT MANAGEMENT (40)

a. Provide single point interface between ICF KH and WHC.

b. Prepare Engineering Work Plan.

c. Provide daily management of project activities.

d. Ensure the project technical, budget, and schedule objectives are met.

e. Disposition client comments.

f. Hold bi-weekly status meetings with client and prepare meeting minutes.

g. Hold weekly design team meetings.

- WORD PROCESSING (4I)

a. Provide word processing services for the Construction and Procurement Specifications.

- $\quad$ ACCEPTANCE INSPECTIONS (44)

a. Provide independent engineering assessment of the project design as required by WAC-173-303-640.

b. Prepare Acceptance Inspection Plans for early procurement and construction.

c. Provide vendor surveillances on early procurement contracts as required.

- PROJECT CONTROLS (45)

a. Provide a cost and scheduling services.

b. Provide weekly/monthly schedule and cost analys is and variance reporting.

- $\quad$ SUBCONTRACT/PROCUREMENT (49)

a. Provide procurement review and input to procurement schedule.

- CONSTRUCTION FORCE ADHINISTRATION (60)

a. Perform constructability review of concept.

b. Assist in job walks by engineering.

- SURVEY (62)

a. Provide survey services to support route planning for underground piping and conduit.

b. Provide scanning services of valve pits to support valve manifold designs.

CONSTRUCTIBILITY (63)

a. Perform a Constructibility Review of the Definitive Design documents prepared by ICF KH.

- RECORDS MANAGEMENT (65)

a. Establish and maintain project records.

b. Provide document distribution support services. 


\subsection{ASSUMPTIONS}

\subsection{Civi1/Structural/Environmental}

14.1.1 Safety classifications - the valve pits and associated cover blocks and waste transfer lines are assumed to be SC 2 using SC 1 seismic loads. The primary vent system are assumed to be SC 2 . Shielding walls, roof structures, and stack supports are assumed to be SC 3 over SC 2. All other items, as related to the civil/structural/environmental discipline, are assumed to be either SC 3 or SC 4.

14.1.2 The engineering estimate accounts for similarities between the various tank farms and planned equipment upgrades, with the estimates reduced for subsequent items of similar design as an economy of scale.

\subsection{Piping}

14.2.1 The engineering estimate assumes the deliverables will only show the upgrades covered under this project and necessary interfaces with existing equipment. There is no allowance for incorporating all existing infrastructure (i.e., as-built drawings).

14.2.2 Title I design provides completed, approved P\&IO's and flow diagrams before commencing Title Il design activities.

14.2.3 Each valve pit manifold design will require 8 jumper assemblies while the drain pit will require 7 jumper assemblies.

\subsection{HVAC}

14.3.1 The design will be modular to the extent that special effluent treatment devices. (such as absorbers for organic and/or ammonia control) can be easily connected in the future.

14.3.2 The existing underground ventilation piping is in good condition and does not require replacement.

14.3.3 The design will assume that existing ventilation equipment will be removed with the new equipment located in a nearby area.

14.3.4 The new primary ventilation equipment will be generic to AN, AP, and AW Tank Farms; the capacity may be adjusted to suit each individual farm. The OCRT's will require new designs.

14.3.5 The primary ventilation systems are assumed SC 2 for confinement and SC 3 for operation. The annulus ventilation system is assumed SC 3 for confinement and SC 3 for operation. 
WHC-SD-W314-CDR-001, Rev. 0

Page 72 of 84

\subsection{Instrumentation}

14.4.1 Includes no allowance for interferences or disagreements with devices and methods selected by the systems engineering effort.

14.4.2 P\&ID's and IEFD's are approved in Title I and require no additional effort in Title II.

14.4.3 No demolition drawings, including red-lined existing drawings, are intended to be released for construction (except where noted).

14.4.4 ECNs or ECN incorporation of existing drawings is included in Title III.

14.4.5 All instrumentation will be SC 3 .

14.4.6 Primary tank liquid level: The existing drawing $\mathrm{H}-2-817634$ is sufficient for installation of the "Enraf" displacement level gage in all DSTs.

14.4.7 Primary tank waste temperature: The primary tank temperature measurement design described by existing drawings $\mathrm{H}-2-815181$ and $\mathrm{H}-2-817863$ is an adequate design for all identified tanks and requires no extensive redesign. Only minor modifications are required to use drawings as part of the procurement specification. These aforementioned drawings are the sole drawings contained in the procurement specification.

14.4.8 Waste transfer valve positioning: Position switches/elements are a supplied item on the valves. The valves are supplied with a cable, connector, and mating connector for transmitting position information outside the pit.

14.4.9 Waste transfer monitoring: Flow meters can be installed inside all central pump pits. Magnetic or ultrasonic flow meters can be used.

14.4.10 Tank annulus liquid presence detectors: Existing riser is usable for standard "floor mount" leak detector design.

14.4.11 Tank annulus exhaust air leak detector: Modification of existing cabinet to install new CAM is adequate and no new cabinet or sample line is required.

14.4.12 Leak detection pit, gamma radiation monitor: A commercially available "off the shelf" probe and transmitter will cover entire operating range.

14.4.13 Leak detection pit, liquid lead detector: The pit will be dry and sampling with lab analysis is sufficient for density.

14.4.14 Pipeline leak detectors: End (low) point leak detection is sufficient as opposed to continuous.

14.4.15 Master pump shutdown for $A Y$ and $A Z$ Tank Farms controls not only a pump in each central pump pit but also one pump for the sluice pits.

14.4.16 Ventilation, primary exhaust: No buried duct or vent pits require leak detection. 
Page 73 of 84

14.4.17 Ventilation, primary exhaust stack monitor: The GEMS specification is adequate for procuring the stack monitor and requires minimal text changes before issuance. The specification requires no new drawings and contains sufficient information to install the pieces on the construction $\mathrm{pl}$ an and elevation installation drawing. The GEMS specified system has outputs adequate to transmit all signals to the TFLAN

1/0 box over the required range, speed, accuracy, etc. 242-A DCS alarms: Forty signals need to be connected (replicated) from the TFLAN PLC/MMI to the existing DCS.

14.4.19 TMACS miscellaneous signal inputs: The 8 "Panalarm" to TMACS modem installations assumes a capable "Panalarm" already in place. No logic diagrams are required.

14.4.20 TFLAN system component: MMI faceplate is necessary for each tank, each exhaust train, two for the tank farm overview, and faceplates for the area (1 for 200W and 2 for $200 E$ ).

14.4.21 TFLAN system component: TMACS programing is done by experienced TMACS personnel.

14.4.22 TFLAN system component: Al] signals from the tank farms will be monitored in the local instrument building as well as at $2750 E$ by TMACS.

14.4.23 The scope of the 242-S control room demolition is based on 76 points found on drawing H-2-46436. The 76 points identified do not include any signals pertaining to the 242-S building and does not include any "GAMEWELL" or "CASS" signals that remain to be identified. The signals moved will only be those associated with the tank farms. Project W-314 will not ensure the associated equipment is operational.

\subsection{Electrical}

14.5.1 All electrical power will be SC 3 .

14.5.2 The existing 13.8. kV utility feeders have enough capacity to meet the demands for existing and future power requirements. 


\section{ENGINEERING STATEMENT OF WORK}

\section{FOR TITLE III ENGINEERING/INSPECTION ACTIVITIES}

\section{PROJECT: W-314, TANK FARY RESTORATION AND SAFE OPERATIONS \\ PREPARED BY: ICF KAISER HANFORD COMPANY}

DATE: APRIL 23, 1996

ICF KH will provide engineering and inspection services during the construction of this project. For the main design disciplines of Civil/Structural, Piping, HVAC, Instrumentation, and Electrical, that support will include:

a. Review and disposition of Fixed Price Contractor submittals.

b. Prepare and issue Engineering Change Notices (ECNs).

c. Disposition Nonconformance Reports (NCRs).

d. Attend construction meetings.

e. Be available to assist construction personnel in resolving technical issues.

The above engineering efforts during construction and construction itself will be supported by the following disciplines:

- ENVIRONMENTAL ENGINEERING (22)

a. Perform overview and approval of all project ECNs and NCRs for compliance with appropriate environmental regulatory requirements.

b. Attend meetings and field trips as required to support construction activities.

- DESIGN ADMINISTRATION (35)

a. Coordinate and provide administration for engineering activities.

b. Support the Principle Lead Engineer (PLE) on the project.

c. PLE to perform fieid walkdowns and safety inspections of the construction work.

- PROJECT MANAGEMENT (40)

a. Provide overall coordination of all

Engineering/Inspection and Construction activities.

b. Responsible for cost and schedule performance and reporting.

c. Coordinate project completion and turnover to the Operating Contractor.

d. Perform field walkdowns and safety inspections of the construction work. 
Page 75 of 84

e. Provide single point of contact for the client.

- HORD PROCESSING (41)

a. Provide word processing services for Acceptance Test Procedures (ATPS).

- $\quad$ ACCEPTANCE INSPECTIONS (44)

a. Provide independent assessment verification of certain critical construction processes required by WAC-173-303-640.

b. Provide acceptance inspection services for all project construction.

c. Provide weekly inspection reports.

d. Prepare NCRs as necessary.

e. Conduct acceptance performance testing.

- PROJECT CONTROLS (45)

a. Provide a cost and scheduling services.

b. Provide weekly/monthly schedule and cost analysis and variance reporting.

- $\quad$ SUBCONTRACT/PROCUREMENT (49)

a. Provide procurement review and input to procurement schedule.

- RECORDS MANAGEMENT (65)

a. Maintain project records.

b. Provide document distribution support services.

- AS-BUILTINg (66)

a. As-built the drawings, specifications and ATPs at the completion of the project.

b. Update existing drawings to reflect changes the project has made. 
WHC-SD-W314-CDR-001, Rev. 0

Page 76 of 84

OPERATING CONTRACTOR STATEMENT OF WORK

PROJECT:

W-314, TANK FARM RESTORATION AND SAFE OPERATIONS

PREPARED BY: MESTINGHOUSE HANFORD CONPANY

DATE:

APRIL 23, 1996

\subsection{OBJECTIVES}

The Operating Contractor shall perform those activities required to support the Tank Farm Restoration and Safe Operations (TFRSO) effort, Project $W-314$, from initial project development through completion of construction and turnover to operations. These activities include overall project management (WBS 1); permitting and safety (WBS 2); and $O P C$ activities (WBS 3 ).

With the exception of the expense-funded WBS 3 activities, all activities addressed in this SOW are capitally-funded, in accordance with DOE Cost Estimating Manual, Volume 6.

\subsection{CAPITAL (PACE) FUNDED SCOPE}

WBS 1.1A - Project Management and Integration

- Provide overal1, day-to-day management and oversight of project activities and ensure that appropriate project support is obtained as needed to meet the project objectives

- Prepare and maintain required project documentation and records

- Interface with $\mathrm{DOE}, \mathrm{A}-\mathrm{E}(\mathrm{s})$, construction/construction management subcontractors, onsite Engineer/Constructor, and Operating Contractor personnel (Program Office, Tank Farm Operations, etc.) to ensure good communication concerning project activities and needs, and to facilitate integration with other. TWRS activities

- Coordinate configuration management activities in accordance with the project Configuration Management Plan

- Coordinate risk identification/analysis/mitigation activities in accordance with the project Risk Management Plan

- Support budget validations, Key Decisions, and major reviews

- Provide technical direction to the design and construction subcontractors 
WHC-SD-W314-CDR-001, Rev. 0

Page 77 of 84

- $\quad$ Support project closeout activities

\section{WBS 1.1B - Systems Engineering (SE) Management}

- Update/maintain project Systems Engineering Management Plan (SEMP) during design/construction phases

- Monitor project activities to ensure conformance to the project SEMP and other applicable SE requirements

- Provide SE guidance to the Project Manager and subcontractor personnel as required to support the design activities

- Interface with TWRS and Site SE organizations to ensure consistency of SE applications

- Support project design reviews

\section{WBS 1.1C - Project Controls/Business Management}

- Provide progress reporting and maintain budgetary documentation for project activities

- Coordinate development of project cost and schedule input to programmatic work plans

- Prepare and manage project cost account plans, schedules, and supporting documentation

- Maintain/update required project administration and management documentation (Project Plan, Project Management Plan, etc.)

- Coordinate the Operating Contractor's project-related TPA milestone tracking/reporting to support DOE's commitments with the State

WBS 1.10 - Quality Assurance

- Conduct reviews, surveys, interviews, and spot inspections, as required, to ensure that the $\mathrm{H}-314$ Quality Assurance Program Plan (QAPP) is appropriately implemented by all parties during the design and construction phases

- Document any deviations or deficiencies in QAPP implementation, and work with appropriate parties to resolve/correct these deficiencies

- Maintain the project QAPP to refiect current requirements and conditions throughout the life of the project 
WHC-SD-W314-CDR-001, Rev. 0

Page 78 of 84

WBS 1.2A - Permits

- Prepare Notice of Construction and supporting documentation to meet Clean Air Act permit requirements

- Prepare and submit a modification to the Hanford Site Double-Shell Tank RCRA Part B permit application, if required

- Prepare pre-operational monitoring determination report for affected facilities prior to construction.

- See Appendix $J$ for further permitting details

WBS 1.2B - Safety Analysis

- Perform Unreviewed Safety Question (USQ) determinations and safety analyses, as needed, to support the definitive design and to ensure that project activities have been appropriately assessed for impacts to the existing Tank Farm safety envelope

- Develop updates for tank farm safety analysis documentation (Safety Analysis Report, Safety Equipment List, etc.), if required based on USQ determinations

\subsection{EXPENSE-FUNDED (OPC) SCOPE}

The following Operating Contractor activities are included as other Project Costs (OPC), as defined in Table 4-1, "TPC and TEC Guidance and Clarification, Inclusion in Detailed Activities in TPC and/or TEC," Volume 6 of the draft DOE Cost Estimating Manual:

\section{WBS 1.3A - Project Definition}

- Prepare draft Justification of Mission Need (JMN) documentation to support RL's request for Key Decision 0 , and assist RL in resolving any comments

- Prepare and issue Engineering Studies in support of the TFRSO project definition effort (e.g., ROM scoping, cost estimates, and schedule information)

- Prepare initial Systems Engineering (SE) documentation to support the TFRSO project's Conceptual Design Phase activities, including:

- Functions and Operational Requirements (F\&OR)

- Mission Analysis Report (MAR)

- Requirement Allocation Sheets (RASs)

- Design Constraint Sheets (DCSs)

- Identification of required Trade Studies

- Preliminary Design Requirements Document (PDRD) 
- Provide program/project management, planning, coordination and oversight for the project definition tasks

\section{WBS 1.3B - Program Integration and Support}

- Develop planning to support system assessments of existing Tank Farm structures, systems, and components

- Perform Condition Assessment Survey (CAS) field walk downs and inspections to evaluate/document the physical condition of existing structures, systems, and components

- Evaluate performance capabilities of the existing structures, systems, and components in terms of meeting the established function-based requirements and constraints (PDRD)

- Prepare and submit Facility Assessment Report(s) to support programmatic planning and W-314 Conceptual Design tasks

- Develop weighted need/value added checklist using criteria by which programmatic planning decisions can be based for the Tank Farm work scope.

- Evaluate all required work scope against the weighted need/value added criteria

- Develop preliminary "Master Plan" documentation to specifically identify the scope of work for Project W-314

- Complete Tank Farm Upgrades "Master Plan" which addresses all of the programmatic planning for the Tank Farm activities, including Project W-314

- Provide general project management support for all Conceptual Design Phase tasks, including detailed planning; coordination/integration management; oversight of design and technical 1 iaison with RL, A-Es and subcontractors; and project status tracking/reporting

- Coordinate the Operating Contractor's project-related TPA milestone tracking/reporting to support DOE's commitments with the State

- Develop and issue "Late Validation" documentation, including engineering report, cost estimate, etc., for the $W-314 G$ (AW Tank Farm) scope, and support presentation to DOE-HQ validator (August 1995)

- Identify follow-up conceptual-level refinements and/or new tasks needed to further define the project's Systems Engineering basis before Title I Design (i.e., Advanced Conceptual Design), and 
perform detailed planning in support of ACD deliverables (currently TBD)

- Develop offsite A-E utilization strategies for use during $A C D$, Title I, Title II, Title III, and procurement/construction, and provide support to A-E Selection and Procurement, WBS 1.3.H.

- Perform ACD tasks as identified in detailed planning and integrate the results of this work with existing documentation, including updates to the DCBL documentation and project baseline.

- Perform and document detafled planning in support of Title I Design activities.

\section{WBS 1.3C - Design and Construction Support}

- Provide technical and logistical support to Title I and II design efforts, as required.

- Review the Title I and II design media for operability, maintainability, quality, safety, and environmental considerations

- Review project design documentation to ensure that applicable regulatory requirements, and other environmental considerations, have been appropriately addressed

- Support Project Manager in reconciliation of design review comments and issues

- Provide review of procurement and construction submittals

- Provide technical and logistical support to Title III engineering effort, as required

- Review Engineering Change Notices, Nonconformance Reports, and other documentation, as required, for operability, maintainability, quality, safety, and environmental considerations

\section{WBS 1.3D - Conceptual Design}

\section{WBS 1.3D1 - W-314G Engineering Report}

Develop engineering report similar to CDR to be utilized during FY 97 validation process for establishment of cost and schedule baselines

\section{UBS 1.302 - Design Configuration Baseline (DCBL)}

Continue Systems Engineering $\mathrm{planning}$ and development of project requirements documentation, based on the approved $W-314$ Systems 
Engineering Approach Review package (WHC-SD-W314-XX-002), including:

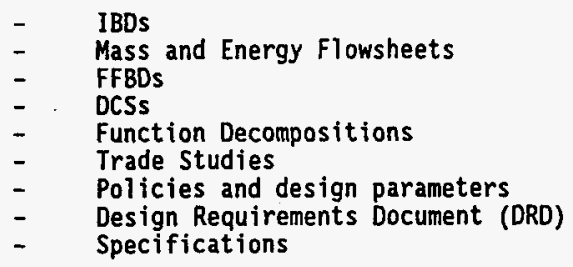

- Develop and issue interface control documentation addressing all project interfaces, including both internal project interfaces (between facilities, and system/subsystem elements) and external interfaces (with other programs/activities/projects)

- Support RL Decision Point Reviews (DPRs) and System Design Review (SDR) in accordance with RL's Systems Engineering Statement of Work (SE-SOW) and other applicable guidance

- Issue Design Configuration Baseline (DCBL) package, containing the completed $\mathrm{W}-314$ Conceptual Design documentation, to RL and support the field office review and approval process

WBS 1.3D3 - Conceptual Design Report (CDR)

Activity provides for development of a CDR consistent with RL 4700 requirements for the purpose of supporting a successful FY 98 full project validation.

\section{WBS 1.3D4 - Advanced Conceptual Design}

Upon completion of CDR/DCBL, an advanced conceptual design effort will be initiated in order to confirm significant assumptions and address any significant uncertainties identified during conceptual design activities. This activity will enure an orderly and efficient transition into Title 1 definitive design. A value engineering session will be conducted to evaluate alternate methods of achieving project objectives.

\section{WBS 1.3E - Preliminary Safety Documentation}

- Prepare safety evaluations and other safety documentation to support W-314 Conceptual Design activities

- Perform initial Unreviewed Safety Question (USQ) determinations and safety analyses to ensure that project activities have been 
appropriately assessed for impacts to the existing Tank Farm safety envelope

- Develop planning for any follow-up safety analyses or documentation updates that may be required for existing Tank Farm safety analysis reports (WBS 1.2.B), based on the USQ/safety analysis activities, and integrate with the project's Title I/II planning

\section{WBS 1.3F - Permitting Plan}

- Prepare and issue a regulatory compliance POC checklist for the project, based on the DCBL package documentation

- Prepare and issue a Permitting Plan for the W-314 project, identifying the specific permitting requirements, permitting strategy, schedule, and resources required for the acquiring applicable permits

\section{WBS 1.36 - NEPA Documentation}

- Provide planning and guidance to ensure that all project activities are conducted in accordance with the National Environmental Policy Act (NEPA) as required by 10 CFR 1021, "National Environmental Policy Act; Implementation Procedures and guidelines Revocation; Final Rule and Notice," and applicable DOE policies

- Coordinate project NEPA strategy and planning with appropriate RL and Operating Contractor organizations

- Advise W-314 Project Manager on alternatives with regard to NEPA documentation development and provide recommendations that will ensure an adequate assessment of environmental impacts is performed and documented

- Prepare and submit to RL documentation to support RL's NEPA Action Description Memorandum to DOE-HQ, and assist in resolving any DOE-HQ comments

- Prepare and submit a NEPA Environmental Assessment (EA) for the W-314 upgrades to RL, and support RL's review and approval process

- Support RL's submittal of this documentation to DOE-HQ, and assisting resolving $\mathrm{DOE}-\mathrm{HQ}$ comments as required

WBS 1:3H - A-E Selection and Procurement

- Select appropriately qualified personnel and convene the Architect-Engineer Evaluation Board 
- Develop A-E evaluation and procurement documentation (evaluation criteria, statement of work, request for qualifications, etc.)

- Review and evaluate A-E proposals and submittals, conduct interviews, and perform site visits, as required, to select offsite $A-E(s)$ to perform the Advanced Conceptual Design and subsequent engineering services

- Prepare and approve offsite A-E contractual documents and issue Notice to Proceed

WBS 1.3I - Quality Assurance Program PTan

- Support project engineering and systems engineering staff in identification of appropriate quality requirements and considerations during DCBL development

- Prepare and issue the Project H-314 QAPP based on the project's conceptual design documentation (DCBL), preliminary safety documentation, and other appropriate requirements

WBS 1.3J - Site Characterization

- Determine the representative sampling basis for characterization of current site conditions, and extract soil samples

- Conduct analysis of samples and issue results to support Title 1 and Title II Design

\section{WBS 1.3K Start-up Testing}

- Provide/coordinate startup spare parts, consumable and equipment

- Support pre-operational testing after turnover to Startup/Operations

- Support pre-operational testing

- Prepare operating, maintenance, calibration and surveillance procedures.

- Prepare test specification to support pre-operational and operational test procedure development.

- Provide reviews of design, procurement specifications, ATPs and contractor submittals

- Witness and/or verification of factory acceptance testing and construction acceptance testing. 
- Participate in project completion walkdowns and deficiency punchlist generation, turnover package reviews and startup custody.

- Develop and provide support to Operational Test Procedures including performance and deficiency resolution during initial operations

- Prepare maintenance $p l$ ans and verify the inventory of critical spares

- Develop operating procedures

- Develop operator training programs and conduct training for operations personnel

- Conduct readiness reviews and issue ORR reports

- Resolve DOE readiness review comments, as required

KBS 1.3L Operation. Preparations

- Provide for ORR preparation and support execution.

- Perform OC Readiness Review prior to ORR.

WBS 1.3N Independent Reviews

- Perform Preliminary Design Review (POR) for Project W-314 Title I design.

- Perform Critical Design Reviews (CDRs) for each Title II design package (10 total).

- Perform Operational Readiness Review (ORR) for each Construction Work Package (10 total).

WBS 1.5.x.5 and 1.6.x.6 HPT Support

- Provide dedicated HPT support during construction. 


\section{APPENDIX D}

Conceptual Project Schedule 


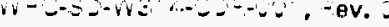

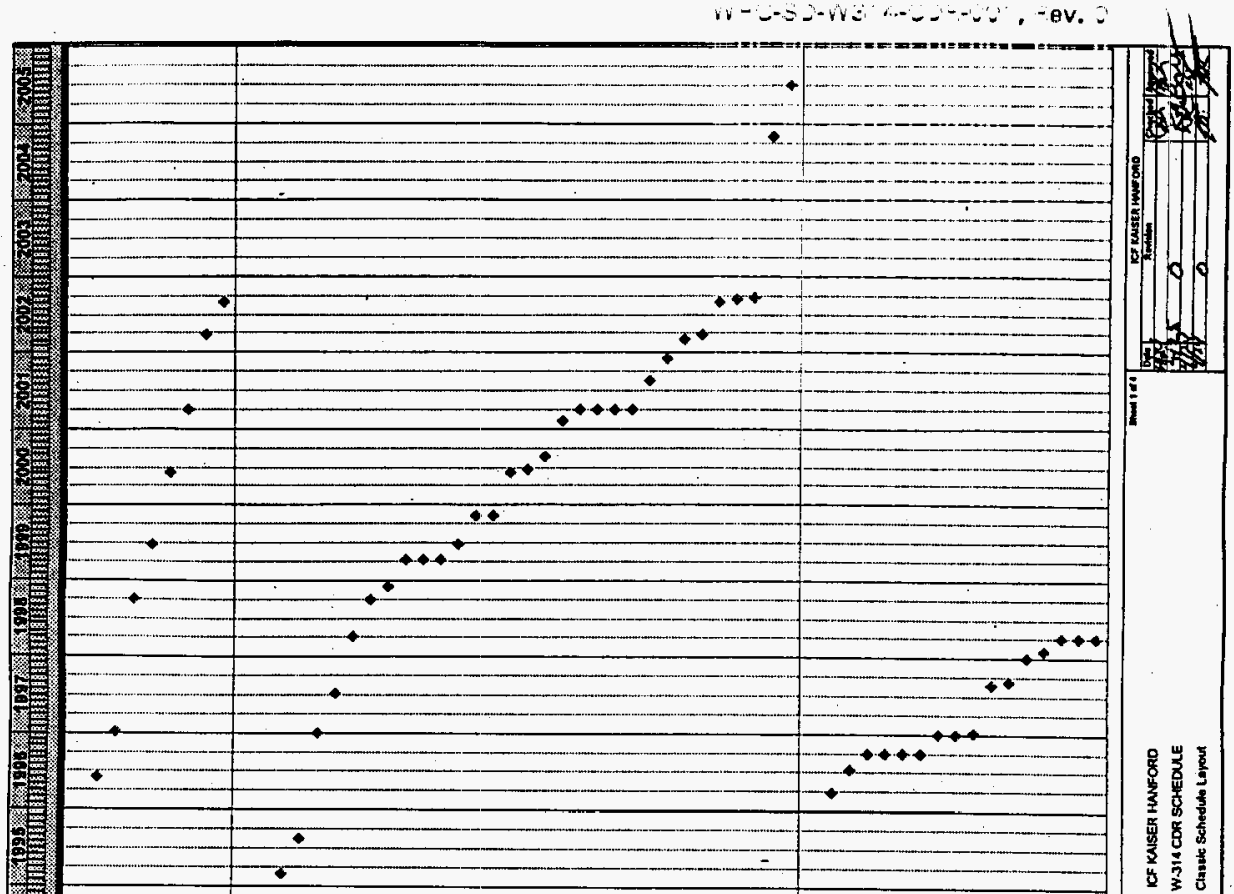

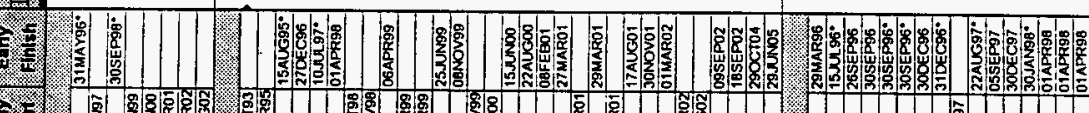

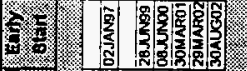

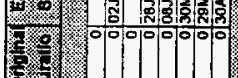

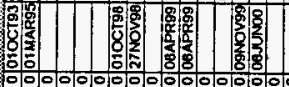

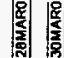

00000000.0000000000000000 .0000

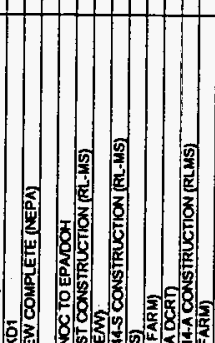

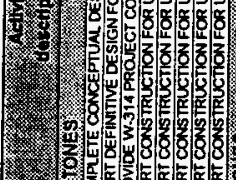

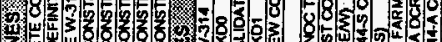

(2)

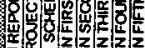

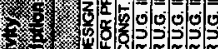

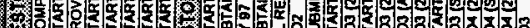

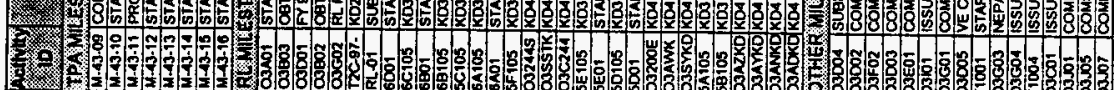

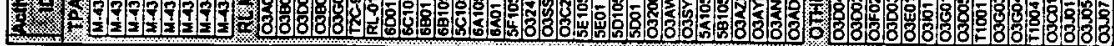

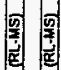

000000000000000
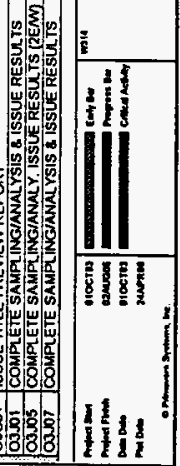

$D-1$ 
$W H C-S D-W 314-C D R-001 ;$ Rev. 0

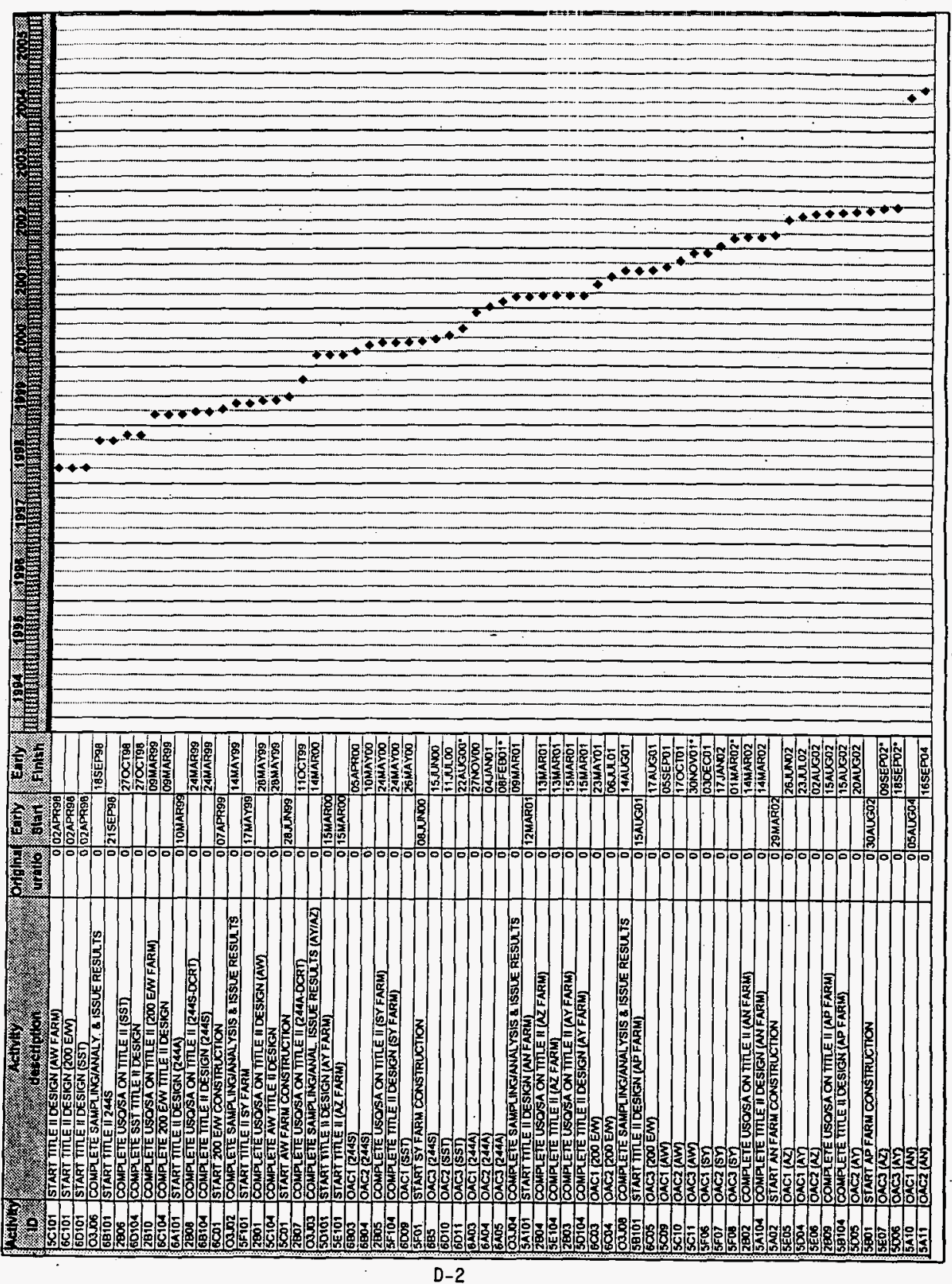


W-C-SD-W3 14 -CDR-001, Rev. 0

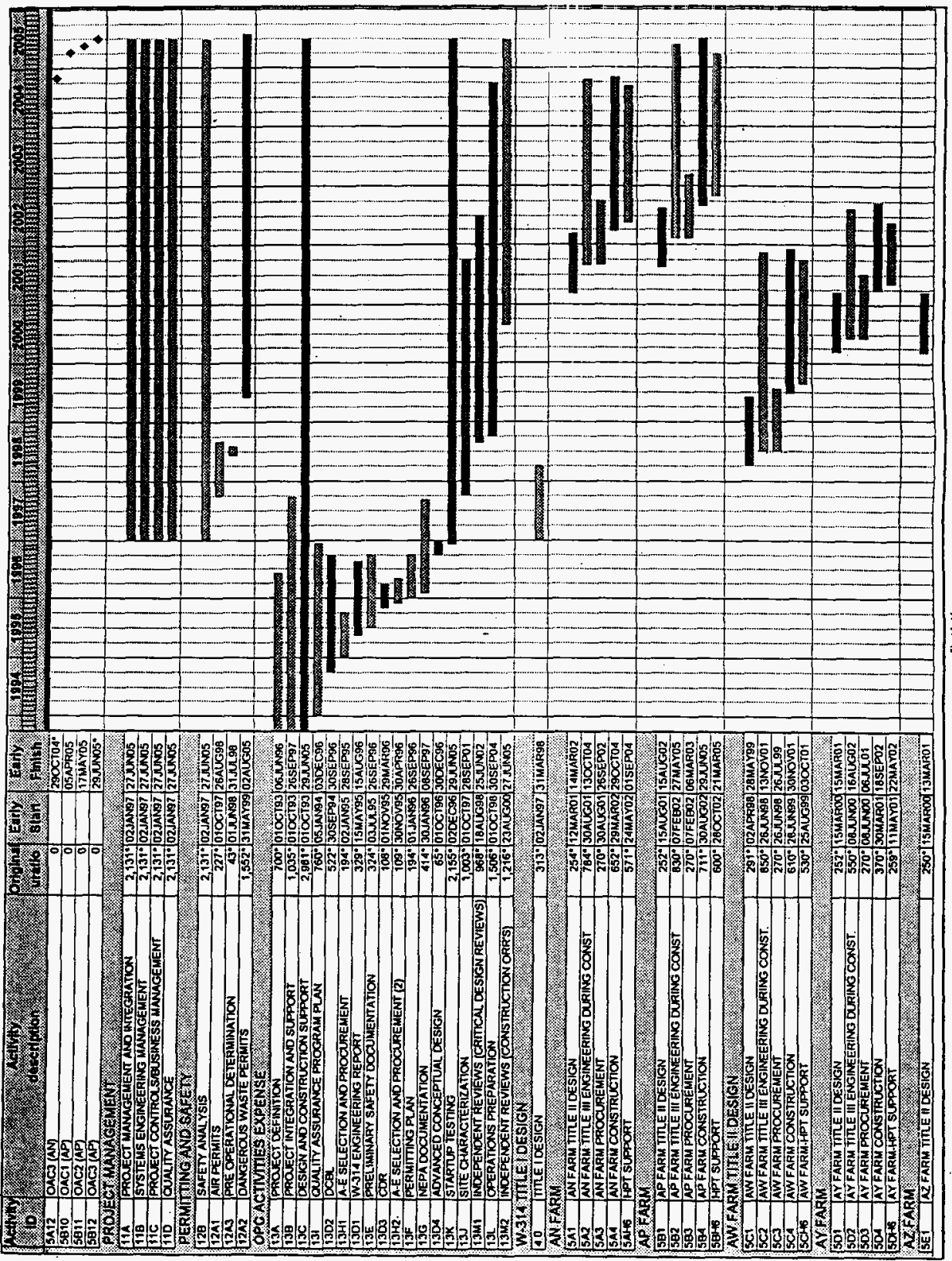
$D-3$ 


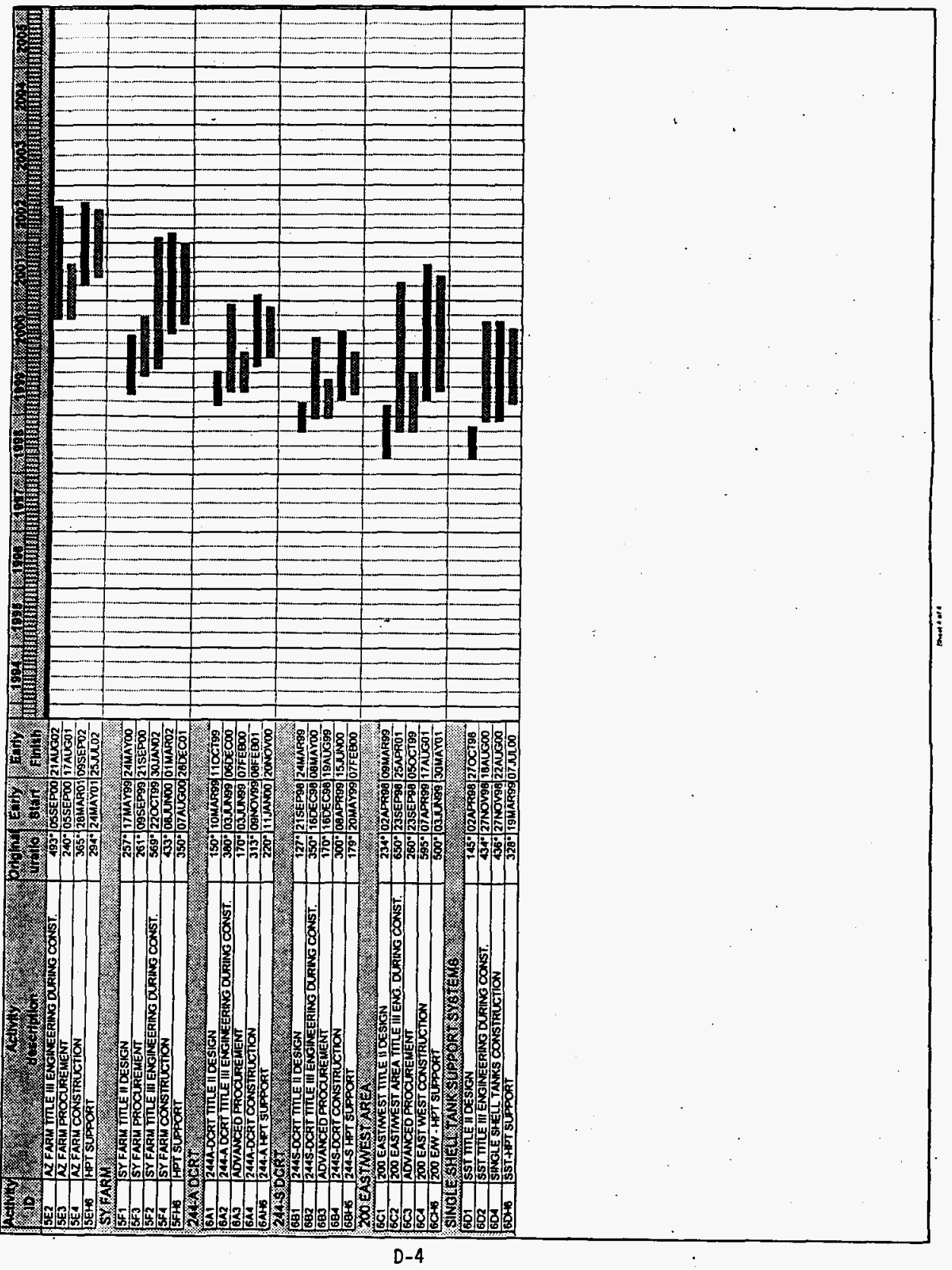




\section{APPENDIX E}

\section{Outline Specification}
Application Matrix
E-1 - E-7
Specification Divisions
$E-8-E-26$ 


\begin{tabular}{|c|c|c|c|c|c|c|c|c|c|c|}
\hline \multicolumn{11}{|c|}{ OUTLINE SPECIFICATION A } \\
\hline \multirow{2}{*}{$\begin{array}{c}\text { SPECIFICATION } \\
\text { DIVISION/SECTION }\end{array}$} & \multicolumn{7}{|c|}{ Tank Farms } & \multicolumn{2}{|c|}{ DCRTs } & \multirow[b]{2}{*}{$200 \mathrm{E} / \mathrm{H}$} \\
\hline & AN & $\mathbf{A Z}$ & AY & AW & AP & SY & SST & 244-A & $244-5$ & \\
\hline \multicolumn{11}{|l|}{ DIVISION 2 - SITEWORK } \\
\hline \multicolumn{11}{|l|}{ Section 02050 Dernolition } \\
\hline \multicolumn{11}{|l|}{ 1. Roinforted Conerote } \\
\hline -. Core Drif & $x$ & $\mathbf{x}$ & $\mathbf{x}$ & $x$ & $x$ & $x$ & & $x$ & & \\
\hline b. Pertial Removal & $x$ & $x$ & $x$ & & $x$ & & & $x$ & & \\
\hline 2. Cover Blocke & $x$ & $x$ & & & $x$ & & & & & $x$ \\
\hline 3. Alphatie Concrate & & & & & & & & & & $x$ \\
\hline \multicolumn{11}{|l|}{ 4. Utithie: } \\
\hline -. Eloctrical \& Signal Wiro/Cable & $x$ & $x$ & $x$ & $x$ & $x$ & $x$ & $\mathrm{x}$ & $x$ & $x$ & $x$ \\
\hline b. Eloctrical Equipment & $x$ & $x$ & $x$ & $\mathbf{x}$ & $x$ & $x$ & & $x$ & & $x$ \\
\hline \multicolumn{11}{|l|}{ 5. Inmtnuments a Controls } \\
\hline -. Tank Lovel Mossurement Devices & $x$ & $x$ & $\mathbf{x}$ & $x$ & $x$ & $x$ & & $\mathbf{x}$ & & $\mathbf{x}$ \\
\hline b. Tank High Lovel Alorms & $x$ & $\mathbf{x}$ & $\mathrm{x}$ & $\mathrm{x}$ & $x$ & & & & & \\
\hline c. Tank \& Waste Temp. Devices & $\mathbf{x}$ & $\mathbf{x}$ & $\mathbf{x}$ & $x$ & $x$ & $x$ & & $\mathbf{x}$ & & $\mathbf{x}$ \\
\hline d. Vapor Space Presture Devices & $x$ & $\mathbf{x}$ & $x$ & $x$ & $x$ & $x$ & & $x$ & & $x$ \\
\hline - Aew Woter Flow Mater & 1 & 1 & 1 & 1 & 1 & 1 & & 1 & & 1 \\
\hline f. Tank Annulus Liquid Dotector: & $x$ & $\mathbf{x}$ & $x$ & $x$ & $x$ & $x$ & & $x$ & & $x$ \\
\hline o. Annulus Air Dotectore (CAMs) & $x$ & $\mathbf{x}$ & $x$ & $\mathbf{x}$ & $x$ & $x$ & & $x$ & & $\mathbf{x}$ \\
\hline h. Loak Datection Pit Red Manktors & $x$ & $x$ & & $\mathbf{x}$ & $\mathbf{x}$ & $x$ & & & & \\
\hline 1. Leak Detection Pit Leak Detectors & $x$ & $\mathbf{x}$ & $x$ & $x$ & $x$ & $x$ & & & & $x$ \\
\hline j. Procesen Pit Loak Detectors & $x$ & $x$ & $x$ & $x$ & $x$ & $x$ & & $x$ & $x$ & $x$ \\
\hline k. Clean Out Box Leak Detoctore & $\mathbf{x}$ & $\mathbf{x}$ & $\mathbf{x}$ & $x$ & & $\mathbf{x}$ & & & & \\
\hline I. Pipelino Leak Dotectors & $x$ & $x$ & $x$ & $x$ & $x$ & $x$ & & $x$ & $\mathbf{x}$ & $x$ \\
\hline m. Master Pump Shutdown Switchos & $x$ & $x$ & $x$ & & $x$ & $\mathbf{x}$ & & $x$ & $\mathbf{x}$ & $\mathbf{x}$ \\
\hline n. Alarms A Reloted Circuitry & $\mathbf{x}$ & $x$ & $x$ & $\mathbf{x}$ & $x$ & $\mathbf{x}$ & & $x$ & $x$ & $x$ \\
\hline D. Tank Primary Vent. Equipmont & $x$ & & & $\mathbf{x}$ & $x$ & & & $x$ & $\mathbf{x}$ & \\
\hline p. Tonk Annulus Vont. Equipment & & & & & & $\mathbf{x}$ & & & & \\
\hline q. Primary Vent. Steck Monitor & $x$ & & & $x$ & $x$ & $\mathbf{x}$ & & $x$ & & $x$ \\
\hline r. Soal Pot Level Alarms & & & & & & $x$ & & & & \\
\hline
\end{tabular}




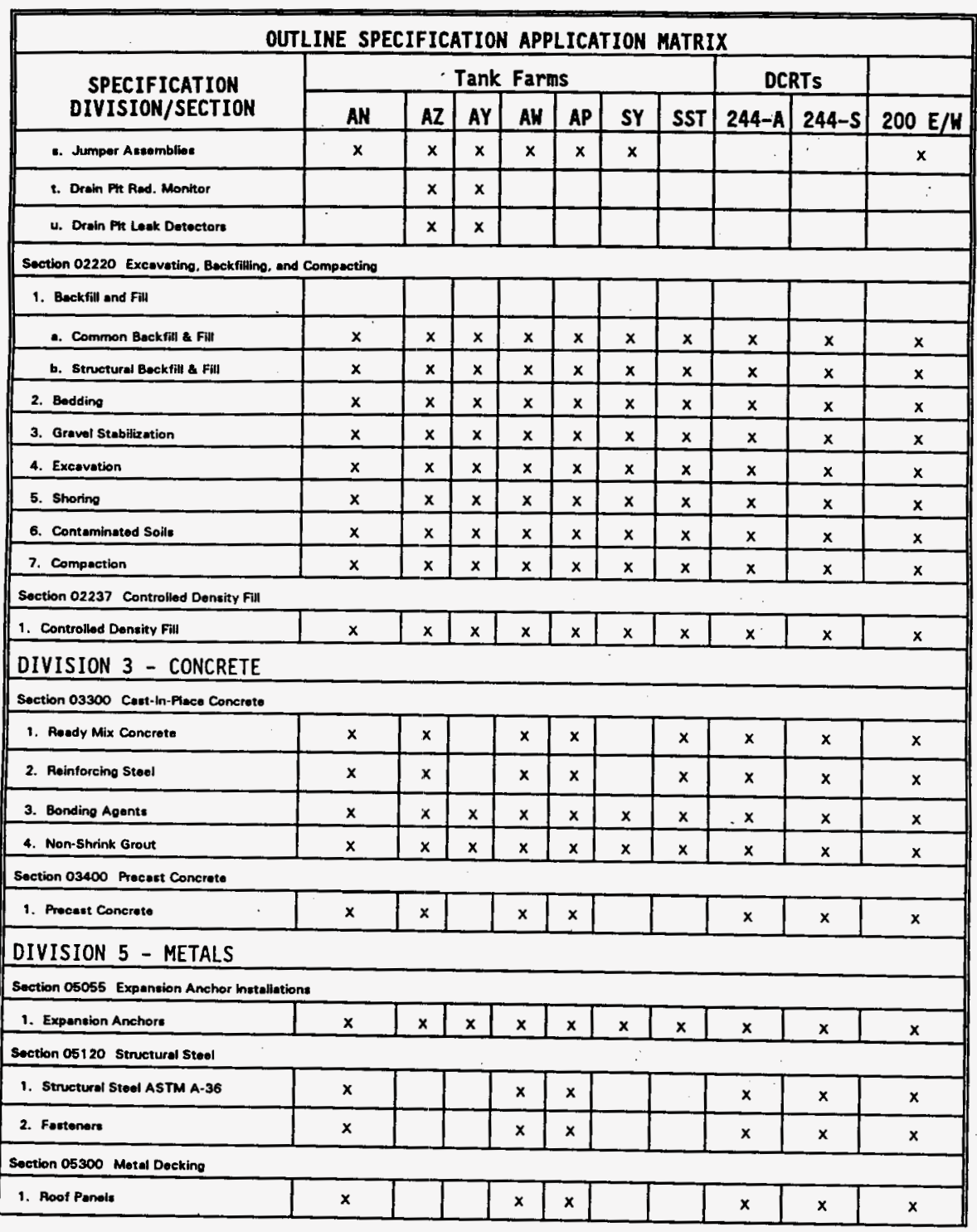




\begin{tabular}{|c|c|c|c|c|c|c|c|c|c|c|}
\hline \multicolumn{11}{|c|}{ OUTLINE SPECIFICATION APPLICATION MATRIX } \\
\hline \multirow{2}{*}{$\begin{array}{l}\text { SPECIFICATION } \\
\text { DIYISION/SECTION }\end{array}$} & \multicolumn{7}{|c|}{ Tank Farms } & \multicolumn{2}{|c|}{ DCRTs } & \multirow[b]{2}{*}{$200 \mathrm{E} / \mathrm{H}$} \\
\hline & AN & AZ & AY & AW & AP & SY & SST & 244-A & $244-5$ & \\
\hline \multicolumn{11}{|l|}{ Section 05500 Motel Febricatione } \\
\hline 1. Mivedulloneous Steol heme & $\mathbf{x}$ & $x$ & $x$ & $x$ & $\mathbf{x}$ & $x$ & $x$ & $x$ & $\mathbf{x}$ & $x$ \\
\hline \multicolumn{11}{|l|}{ DIVISION 9 - FINISHES } \\
\hline \multicolumn{11}{|c|}{ Section 09855 Chemical Roviatent Deconteminable Contings } \\
\hline 1. Decontaminablo Coatinge & $\begin{array}{l}600 \mathrm{tt}^{2} / \text { p.p. } \\
744 \mathrm{tt}^{2} \text { N.p. }\end{array}$ & $x$ & $x$ & $x$ & $x$ & $x$ & & & & $\mathbf{x}$ \\
\hline \multicolumn{11}{|c|}{ DIVISION 13 - SPECIAL CONSTRUCTION } \\
\hline \multicolumn{11}{|c|}{ Soction 13440 kntrumentotion } \\
\hline \multicolumn{11}{|l|}{ 1. Proprommable Logic controller } \\
\hline a.PC & 1 & 1 & 1 & 1 & 1 & 1 & & & 1 & 3 \\
\hline b. FLC Beckplane & 1 & 1 & $t$ & $\uparrow$ & 1 & 1 & & & 1 & $\mathbf{3}$ \\
\hline c. PLC Power Supply & 1 & 1 & 1 & 1 & 1 & 1 & & & 1 & 3 \\
\hline d. Aemote l/O controller & 1 & 1 & 1 & 9 & 1 & 1 & & & & \\
\hline e. Aemote l/O drop cerd & 5 & 2 & 2 & 6 & 4 & 2 & & & & \\
\hline 1. Riemote $1 / 0$ cable top & 5 & 2 & 2 & 6 & 4 & 2 & & & & \\
\hline g. Remote Beckpiane & 5 & 2 & 2 & 6 & 4 & 2 & & & . & \\
\hline h. Remoto vO power supply & 5 & 2 & 2 & 6 & 4 & 2 & & & & \\
\hline 1. PLC Sottware Program & 1 & & & & & & & & & \\
\hline j. Communication Network & 1 & 1 & 1 & 1 & 9 & 1 & & 1 & 1 & 3 \\
\hline k. Communication Card & 1 & 1 & 1 & 1 & 1 & 1 & & 1 & 1 & 3 \\
\hline I. TCP/IP intertece cerd & 1 & 1 & 1 & 1 & 1 & 1 & & 1 & $t$ & 3 \\
\hline m. Analog mput Card & 23 & 8 & 7 & 18 & 21 & 16 & & 9 & 9 & 4 \\
\hline n. Diecrote Output Card & 3 & 2 & $\mathbf{3}$ & 4 & 18 & 5 & & 1 & 1 & 1 \\
\hline a. Discrete Input Cord & 5 & 1 & 1 & 2 & $\theta$ & 2 & & 1 & , & 1 \\
\hline D. ATD input Card & 7 & 5 & 5 & 14 & 18 & 7 & & 1 & 1 & \\
\hline \multicolumn{11}{|l|}{ 2. Man-Mechice Intorfece teminals } \\
\hline - CAT & 1 & 1 & 1 & 1 & 1 & 1 & & 1 & 1 & 3 \\
\hline b. Proceseor & 1 & 1 & 1 & 1 & 1 & 1 & & 1 & 1 & 3 \\
\hline c. Hard Disk & 1 & 1 & 1 & 1 & 1 & 1 & & 1 & 1 & 3 \\
\hline d. Operator interface & 1 & 1 & 1 & 1 & 1 & 1 & & 1 & 1 & 3 \\
\hline
\end{tabular}




\begin{tabular}{|c|c|c|c|c|c|c|c|c|c|c|}
\hline \multicolumn{11}{|c|}{ OUTLINE SPECIFICATION APPLICATION MATRIX } \\
\hline \multirow{2}{*}{$\begin{array}{l}\text { SPECIFICATION } \\
\text { DIVISION/SECTION }\end{array}$} & \multicolumn{7}{|c|}{ Tank Farms } & \multicolumn{2}{|c|}{ DCRTs } & \multirow[b]{2}{*}{$200 \mathrm{E} / \mathrm{H}$} \\
\hline & AN & $A Z$ & AY & AW & AP & SY & SST & 244-A & 244-S & \\
\hline -. Sottware & 1 & 1 & 1 & 1 & $t$ & 1 & & 1 & 1 & 3 \\
\hline \multicolumn{11}{|l|}{ 3. Tenk Lovel Mossurement } \\
\hline a. Dluplecoment lovel aego & 3 & 1 & 2 & 4 & $\mathbf{8}$ & & & & & \\
\hline b. Communicetiont interfece unit & 1 & 1 & 1 & 1 & 1 & 1 & & 1 & 1. & \\
\hline 4. Lquid Conductivity Probes & 95 & 37 & 30 & 82 & e8 & 54 & & 10 & 10 & 20 \\
\hline 5. Tenk Temperature Tree & 4 & 1 & 1 & 4 & $\mathbf{B}$ & & & 1 & 1 & \\
\hline 6. Tank Pressure tronamitter & 14 & 4 & 4 & 12 & 16 & 6 & & 2 & 2 & \\
\hline 7. Watte monitoring flowmoter & 14 & 4 & 4 & 12 & 16 & 6 & & 2 & 2 & \\
\hline B. Raw water monitoring flowmeter & 1 & 1 & 1 & 1 & 1 & 1 & & 1 & 9 & \\
\hline 9. Annulue CAM flesk detectort & 7 & 2 & 2 & 8 & $\mathbf{8}$ & 3 & & 1 & 1 & \\
\hline 10. Primary exhaust presture & 9 & & & 9 & 9 & 12 & & & & \\
\hline 11. Primery oxhauct temperature & 6 & & & 6 & 6 & 16 & & & & \\
\hline 12. Exhoust otack monitoring & 1 & & & 1 & 1 & 1 & & & & \\
\hline \multicolumn{11}{|l|}{ 13. Enclowures and Accessorios } \\
\hline - Inetrumort anelosure & 5 & 2 & 2 & 6 & 4 & 2 & & & & \\
\hline b. Hestar & 5 & 2 & 2 & 6 & 4 & 2 & & & & \\
\hline 14. Limit Switches & 21 & 9 & 9 & 14 & 12 & 14 & & & & 3 \\
\hline \multicolumn{11}{|c|}{ Section 13460 Gsmma Radiation Monitoring Syatem } \\
\hline \multicolumn{11}{|l|}{ 1. Leak Detection Pit } \\
\hline C. Gernme Probs & 7 & 2 & 2 & 6 & $\mathbf{B}$ & 3 & & 1 & 1 & \\
\hline b. Bamms Meter & 7 & 2 & 2 & 6 & 8 & 3 & & 1 & 1 & \\
\hline \multicolumn{11}{|l|}{ 2. Raw Water Backitow } \\
\hline a. Rediation Monhror & & & & & & & & 1 & 1 & \\
\hline b. Dighal Ratemeter & & & & & & & & 1 & 1 & \\
\hline \multicolumn{11}{|l|}{ DIVISION 15 - MECHANICAL } \\
\hline \multicolumn{11}{|c|}{ Section 15493 Chomical Process Piping Syotoms } \\
\hline \multicolumn{11}{|l|}{ A. Procese and Service Piping } \\
\hline 1. Process piping & $x$ & $x$ & $x$ & $x$ & $x$ & $x$ & & & & $x$ \\
\hline 2. Support material & $x$ & $x$ & $x$ & $x$ & $x$ & $\mathbf{x}$ & & & & $x$ \\
\hline
\end{tabular}




\begin{tabular}{|c|c|c|c|c|c|c|c|c|c|c|}
\hline \multicolumn{11}{|c|}{ OUTLINE SPECIFICATION APPLICATION MATRIX } \\
\hline \multirow{2}{*}{$\begin{array}{l}\text { SPECIFICATION } \\
\text { DIVISION/SECTION }\end{array}$} & \multicolumn{7}{|c|}{ Tank Farns } & \multicolumn{2}{|c|}{ DCRTs } & \multirow[b]{2}{*}{$200 \mathrm{E} / \mathrm{W}$} \\
\hline & AN & $A Z$ & AY & AH & AP & SY & SST & 244-A & 244-S & \\
\hline 3. Cethodic protwetion & $x$ & & & & & & & & & \\
\hline \multicolumn{11}{|l|}{ 4. Protective couting } \\
\hline a. Carbon wteel piping & $\mathbf{x}$ & $x$ & $x$ & $x$ & $x$ & $x$ & & & & $x$ \\
\hline b. Curbon etoel eactions & $x$ & $x$ & $x$ & $x$ & $x$ & $x$ & & & & $\mathbf{x}$ \\
\hline c. Stainders stool pipe & $\mathbf{x}$ & & & $x$ & $x$ & & & & & \\
\hline \multicolumn{11}{|l|}{ B. Equipment } \\
\hline 1. Seal pot & 1 & & & 1 & 1 & & & & & \\
\hline 2. Sent pot pit sump pump & 1 & & & 1 & 1 & & & & & \\
\hline \multicolumn{11}{|c|}{ Soction 15500 Heoting, Ventiloting. and Air Conditioning } \\
\hline \multicolumn{11}{|l|}{ A. Materials } \\
\hline 1. Plonum: & $x$ & & & $\mathbf{x}$ & $\mathbf{x}$ & $\mathbf{x}$ & & $x$ & $x$ & \\
\hline 2. Plonum reinforcement & $x$ & & & $x$ & $x$ & $\mathbf{x}$ & & $x$ & $x$ & \\
\hline 3. Supports & $x$ & & & $x$ & $x$ & $x$ & & $x$ & $x$ & \\
\hline 4. Insulation & $x$ & & & $x$ & $x$ & $x$ & & & & \\
\hline 5. Ventilation Piping & $x$ & & & $x$ & $x$ & $x$ & & $x$ & $x$ & \\
\hline 6. Fabrication & $\mathbf{x}$ & & & $x$ & $x$ & $x$ & & $x$ & $x$ & \\
\hline 7. Protoctive cooting & $x$ & & & $x$ & $x$ & & & & & \\
\hline •. Carbon stoel piping & $x$ & & & $x$ & $x$ & & & & & \\
\hline b. Special wectione & $x$ & & & $x$ & $x$ & & & & & \\
\hline c. Stainlese Stool pipe & $x$ & & & $x$ & $x$ & & & & & \\
\hline 8. Underground pipe trenching & $x$ & & & $x$ & $x$ & & & & & \\
\hline \multicolumn{11}{|l|}{ B. Equipment } \\
\hline 1. Exhaust fans: & 2 & & & 2 & 2 & 2 & & 2 & 2 & \\
\hline 2. MEPA fiher housing: & 4 & & & 4 & 4 & 4 & & 5 & 5 & \\
\hline 3. HEPA fittere & 8 & & & e & 8 & 4 & & 5 & 5 & \\
\hline 4. Heating colss & 2 & & & 2 & 2 & 2 & & 3 & 3 & \\
\hline 5. Prefilters & & & & & & 2 & & 1 & 1 & \\
\hline 6. Carbon odsorter housing* & 2 & & & 2 & 2 & & & 2 & 2 & \\
\hline 7. Miet Eliminators & 2 & & & 2 & 2 & & & & & \\
\hline
\end{tabular}




\begin{tabular}{|c|c|c|c|c|c|c|c|c|c|c|}
\hline & SP & FIC & TIOH & APP & ICA & [ON & ATRI & r & & \\
\hline \multirow{2}{*}{$\begin{array}{l}\text { SPECIFICATION } \\
\text { DIVISION/SECTION }\end{array}$} & \multicolumn{7}{|c|}{ Tank Farms } & \multicolumn{2}{|c|}{ DCRTs } & \multirow[b]{2}{*}{$200 \mathrm{E} / \mathrm{H}$} \\
\hline & AN & AZ & AY & AH & AP & SY & SST & 244-A & 244-s & \\
\hline \multicolumn{11}{|c|}{ DIVISION 16 - ELECTRICAL } \\
\hline \multicolumn{11}{|l|}{ Section 16300 Medium Voltege Distrlbution } \\
\hline \multicolumn{11}{|l|}{ A. Motoriat: } \\
\hline 1. Underground condut & - & & & & & & $x$ & & $x$ & \\
\hline 2. Primery cable & & & & & & & $x$ & & $\mathbf{x}$ & \\
\hline a. Conductor & & & & & & & $x$ & & $x$ & \\
\hline b. Conductor ehield & & & & & & & $\mathbf{x}$ & & $\mathrm{x}$ & \\
\hline c. Insulation & & & & & & & $x$ & & $x$ & \\
\hline d. Ineulation shield & & & & & & & $x$ & & $x$ & \\
\hline -. Jaeket & & & & & & & $\mathbf{x}$ & & $\mathbf{x}$ & \\
\hline \multicolumn{11}{|l|}{ B. Equipment } \\
\hline \multicolumn{11}{|l|}{ 1. Equipment encloeures } \\
\hline 2. Dintribution power fues & & & & & & & 36 & & 3 & \\
\hline 3. Lightning arrovter & & & & & & & 36 & & 3 & \\
\hline 4. Distribution transformark & & & & & & & 12 & & 1 & \\
\hline \multicolumn{11}{|l|}{ Section 16400 Service and Distribution } \\
\hline \multicolumn{11}{|l|}{ A. Materials } \\
\hline \multicolumn{11}{|l|}{ 1. Conduint } \\
\hline a. Condult below arede & $x$ & & & $x$ & $x$ & $x$ & $x$ & $x$ & $x$ & \\
\hline b. Exposed conduit & $x$ & & & $x$ & $x$ & $x$ & $x$ & $x$ & $x$ & \\
\hline c. Conduit concealed in concrete & $x$ & & & $x$ & $x$ & $x$ & $\mathbf{x}$ & $x$ & $x$ & \\
\hline 2. Conductor: & $x$ & & & $x$ & $x$ & $x$ & $x$ & $x$ & $x$ & \\
\hline \multicolumn{11}{|l|}{ B. Equipment } \\
\hline \multicolumn{11}{|l|}{ 1. Equipment onclosure: } \\
\hline 2. Motor control contors & & 1 & 1 & & & & & & & \\
\hline -. Motor comroliera(combination) & & 14 & 18 & & & & & & & \\
\hline b. Feeder circult breakera & 1 & 6 & 6 & 1 & 1 & 1 & & & & \\
\hline 3. Panelbourda & & 1 & 2 & & & & 12 & 1 & & \\
\hline -. Erench eireuh breakere & & $\mathbf{3}$ & 4 & & & 4 & 98 & 16 & 6 & \\
\hline
\end{tabular}




\begin{tabular}{|c|c|c|c|c|c|c|c|c|c|c|}
\hline \multicolumn{11}{|c|}{ OUTLINE SPECIFICATION APPLICATION MATRIX } \\
\hline \multirow{2}{*}{$\begin{array}{l}\text { SPECIFICATION } \\
\text { DIVISION/SECTION }\end{array}$} & \multicolumn{7}{|c|}{ Tank Farms } & \multicolumn{2}{|c|}{ DCRTs } & \multirow[b]{2}{*}{$200 E / H$} \\
\hline & AU & AZ & AY & AN & AP & SY & SST & 244-A & 244-S & \\
\hline 4. Combination motor controllere & & 2 & 2 & & & 2 & & & & \\
\hline E. Salety switcher & & & & & & & & 2 & 3 & \\
\hline $\begin{array}{l}\text { 6. Enclosed combination megnotic } \\
\text { starter }\end{array}$ & 2 & & & 2 & 2 & & & 3 & & \\
\hline 7. Variable epoed drive & & & & & & & & 2 & 2 & \\
\hline 8. Mint-power center & 1 & 1 & 1 & 2 & 1 & 1 & 12 & 1 & 1 & \\
\hline a. Menual tranefor ewitch & 1 & & & 1 & 1 & & & & & \\
\hline 10. Wire ounter & 1 & & & 2 & 1 & & & & & \\
\hline 11. Powor roceptecle & 2 & & & 6 & 3 & & & & & \\
\hline 12. Roceptecle ewitch & 1 & & & 1 & 1 & & 36 & & & \\
\hline 13. Enclosed circuit breaker & & & & 1 & & & 1 & & 1 & \\
\hline 14. SCR unit & & 2 & 2 & & & & & & & \\
\hline 15. Circuit brwaker (moin/incoming) & 1 & 1 & 2 & 1 & 1 & & & 2 & & \\
\hline 16. Roceptecles: & 2 & & & 6 & 3 & & & & & \\
\hline 17. Heat trace cable & $x$ & & & $x$ & $\mathbf{x}$ & & & & & \\
\hline 18. Hent tracing control pand & 1 & & & 1 & $\mathfrak{\imath}$ & & & & & \\
\hline Section 16640 Cathodic Pratection & & & & & & & & & & $\cdot$ \\
\hline 1. Anodes: & $x$ & $x$ & $x$ & $\mathbf{x}$ & $x$ & & & & & $x$ \\
\hline 2. Pormenent reference electrodo & 4 & 2 & 2 & 4 & 4 & & & & & $x$ \\
\hline 3. Test atations & 4 & 2 & 2 & 4 & 4 & & & & & $x$ \\
\hline 4. Anode divtribution box & 2 & & & 2 & 2 & & & & & $x$ \\
\hline 5. Conduit & $x$ & $x$ & $x$ & $x$ & $\mathbf{x}$ & & & & & $x$ \\
\hline 6. Conductors & $x$ & $\mathbf{x}$ & $x$ & $x$ & $x$ & & & & & $x$ \\
\hline 7. Exothermic wold mold & $x$ & $x$ & $x$ & $x$ & $x$ & & & & & $x$ \\
\hline B. Exothermic wold motal & $x$ & $x$ & $x$ & $x$ & $x$ & & & & & $x$ \\
\hline 9. Conductor splice kit & $x$ & $x$ & $x$ & $x$ & $x$ & & & & & $x$ \\
\hline 10. Wiremerkers & $x$ & $x$ & $x$ & $x$ & $x$ & & & & & $x$ \\
\hline 11. Cablo markar & $x$ & $x$ & $x$ & $x$ & $x$ & & & & & $x$ \\
\hline 12. Nemeplate & $x$ & $x$ & $x$ & $x$ & $x$ & & & & & $x$ \\
\hline
\end{tabular}




\section{DIVISION 2 - SITEWORK}

\section{Section 02050 Demolition}

1. Reinforced concrete: Remove portions of existing pits, cover blocks, and other structures where shown on the Drawings by means noted in this Specification. Rubble may be contaminated with mixed waste and shall be handled and disposed of in accordance with procedures.
a. Core drilijing.
b. Partial removal including use of saws, core drills, impact tools, and high pressure water blasting equipment to create large openings. Extreme care shall be taken to prevent cracking of structure beyond limits of opening being created.

2. Cover blocks: Remove, decontaminate, and dispose of cover blocks in accordance with procedures.

3. Asphaltic concrete paved surfaces to be disturbed by excavation activities shall be saw cut at the limits of the excavation prior to demolition and removal.

4. Utilities: Disconnect and remove electrical equipment where shown on the Drawings and as noted in this Specification. Dispose of, or stockpile for recycling, as directed.

a. Above ground electrical and signal wire and cable shown on the Drawings to be removed shall be cut at the entrance to conduits or just below grade. Wire, cable, and conduit ends shall be covered or otherwise sealed. Below grade portions of the wire and cable shall be abandoned in place.

b. Electrical equipment.

5. Disconnect and remove instruments and control devises where shown on the drawings and as noted in this Specification. Dispose.of, or stockpile for recycling, as directed.
a. Tank leve] measurement devices.
b. Tank high level alarms.
c. Haste temperature reading devices.
d. Vapor space pressure reading devices.
e. Raw water flow meter.
f. Tank annulus liquid detectors.
g. Annulus air detectors (CAMs). 
h. Leak detection pit radiation monitors.

i. Leak detection pit leak detectors.

j. Process pit leak detectors.

k. Cleanout box leak detectors.

1. Pipeline leak detectors.

m. Master pump shutdown switches.

n. Alarms and related circuitry.

o. Tank primary ventilation equipment.

p. Tank annulus ventilation equipment.

q. Primary ventilation stack monitor.

r. Seal pot level alarms.

s. Jumper assemblies.

t. Drain pit radiation monitor.

u. Drain pit leak detector.

\section{Section 02220 Excavating, Backfilling, and Compacting}

1. Backfill and Fill

a. Common: Well graded and uniformly mixed soil with largest particle being 3 inches in greatest dimension and constituting not more than $40 \%$ in volume.

b. Structural: Well graded and uniformly mixed soil with largest particle being 3 inches in greatest dimension and constituting not more than $20 \%$ in volume.

c. Controlled density: See Section 02237. Material may be used as common and structural backfill and fill if approved by ICF KH.

2. Bedding for utility lines: Sand as defined in ASTM D 653 or excavated sandy material having less than $20 \%$ gravel particles. Gravel particles shall have a maximum dimension of $1 / 2$ inch.

3. Gravel stabilization: Crushed rock with maximum fragment size of $3 / 4$ inch for walkways and 2 inches for other areas. 
4. Excavation: Excavate deep enough to allow laying utility lines at line and grade shown on Drawings after placement and compaction of bedding.

5. Shoring: Provide shoring as required meeting requirements of ICF KH CESH 20.

6. Contaminated soils: Manage and dispose of contaminated soils in accordance with approved Waste Management Plan and applicable procedures.

7. Compaction: For structural fill and bedding, uniformly compact each layer to $95 \%$ of maximum density as determined by specified compaction tests.

\section{Section 02237 Controlled Density Fill}

1. Control density fill mixture:
a. Cement: ASTM C 150, Type II, low alkali.
b. Fly ash: ASTM C 618 , Class $F$ in accordance with recommendations of $40 \mathrm{CFR} 249.12$ and 249.13 .
c. Aggregates: ASTM C 33, 3/8 inch maximum.
d. Air-entraining admixtures: - ASTM C 250 .
e. Measure and mix specified materials and deliver mixture in accordance with ASTM C 94 or WSDOT M 41-10, Section 6-02.3.
f. Provide fill compressive strength of 50 to 100 psi at 28 days.

2. Placement: Place mixture in accordance with ASTM C 94 or WSDOT M 41-10, Section 6-02.3. Discharge directly from truck by pumping or other approved methods.

\section{DIVISION 3 - CONCRETE}

\section{Section 03300 Cast-In-Place Concrete}

1. Ready mixed concrete mixture
a. Cement: ASTM C 150, Type II, low alkali.
b. Fly ash: In accordance with recommendations of 40 CFR 249.12 and 249.13
c. Aggregates: ASTM C 33, 1-1/2 inch maximum size.
d. Air-entraining admixture: ASTM C 260. 

e. Minimum allowable compressive strength: $30001 \mathrm{~b} / \mathrm{in}^{2}$ at 28 days.
f. Proportions: In accordance with ACI 301, Sections 3.8 and 3.9 , and ASTM C 94.

2. Reinforcing steel
a. Steel bars: ASTM A 615, deformed, Grade 60.
b. Welded wire fabric: ASTM A 185 .
c. Tie wire: ASTM A 853 carbon steel, 16-gage minimum, annealed.

3. Bonding agents: Epoxy resin in accordance with WSDOT $M$ 41-10, Section 9-26, Type II, Grade 2, Class B or C; QCM Company EAS8 Class A, Adhesive Engineering "Concresive 1001 LPL," or Protex Industries "Probond 822 ."

4. Non-shrink grout: ASTM C 1107; Sika Corporation "Sika Grout 212," or Master Builders "Masterflow 713."

\section{Section 03400 Precast Concrete}

1. Precast concrete
a. Mix in accordance with ASTM C 94 (Alternate 2).
b. Proportion in accordance with ACI 301, Section 3.8.
c. Minimum allowable compressive strength: $5000 \mathrm{lb} / \mathrm{in}^{2}$ at 28 days.

2. Reinforcing steel
a. Steel bars: ASTM A 615, deformed, Grade 60.
b. Welded wire fabric: ASTM A 185.
c. Tie wire: ASTM A 853 carbon steel, 16-gage minimum, annealed.

\section{DIVISION 5 - METALS}

\section{Section 05055 Expansion Anchor Installation}

1. Expansion anchors (Safety Classes 1 and 2): Hilti Fastening Systems "Kwik-Bolt II."

2. Expansion anchors (Safety $\mathrm{Classes} 3$ and 4): Industry standard wedge type, having a published evaluation report (by International Conference of Building Officials), with anchor descriptions, tables of allowable tension and shear loads, and test findings. 


\section{Section 05120 Structural Steel}

1. Rolled steel shapes and plates: ASTM A 36.

2. Steel bars and rods: ASTM A 108, minimum yield $36,0001 \mathrm{~b} / \mathrm{in}^{2}$, maximum carbon content $0.35 \%$.

3. Steel tubing: ASTM A 500, Grade B, or ASTM A 501.

4. Steel Pipe: ASTM A 53, Type E or S, Grade 8.

5. Fasteners: Class 2 fit.
a. Bolts: ASTM A 325, Type 1 or 2, plain (noncoated) or galvanized; or ASTM A 490, Type 1 or 2.
b. Nuts: ASTM A 563, Grade C, plain, heavy hex, or for galvanized bolts, ASTM A 563, Grade DH, galvanized, heavy hex.
c. Washers: ASTM F 436, circular.

\section{Section 05300 Metal Decking}

1. Roof panels: Standard wide rib, Type WR20 in accordance with SDI Publication No. 26 and manufactured from zinc-coated steel sheets.

\section{Section 05500 Metal Fabrications}

1. Miscellaneous steel items: Fabricate parts from standard structural sections or shapes, to sizes required. Shop paint parts except those to be embedded in concrete or masonry, or those which require other specific finishes.

2. Performance: Verify measurements and take field measurements necessary before fabrication. Provide miscellaneous bolts and anchors, supports, braces, and connections necessary for completion of metal fabrications. Wherever miscellaneous parts are exposed, grind edges, corners, and rough cuts smooth and free of snags. Cut, reinforce, drill, and tap metal fabrications shown to receive finish hardware and similar items. Weld or bolt connections as shown on Drawings.

\section{DIVISION 9 - FINISHES}

\section{Section 09855 Chemical Resistant Decontaminable Coatings}

1. Decontaminable coatings (service level II as defined in ASTM D 5144):

a. Finish coating applied at the specified thicknesses shall demonstrate decontaminability to radioactive solutions by having a minimum decontamination factor (DF) of 50 as 
determined by ASTM D 4256, Method A, or ANSI N512 Section 4. Test samples shall be prepared in accordance with ASTM D 5139 or ANSI N512 Section 7.

b. Chemical resistance: Coating shall be resistant to the standard decontamination solutions listed in ASTM D 3912 , Figure 1. Chemical resistance testing shall be in accordance with ASTM D 3912, or an equivalent standard except test samples coating shall be prepared in accordance with ASTM D 5139 or ANSI N512 Section 7.

c. Coating shall be 'VOC' compliant with a maximum volatile organic content of $2.9 \mathrm{lb} / \mathrm{gallon}$.

d. Primers, thinners, and coating accessory materials shall be produced and/or approved for use by the same manufacturer as the finish coating system. Representative products:

\begin{tabular}{|l|c|}
\hline Product & $\begin{array}{c}\text { Nanufacturer } \\
\text { Ameron }\end{array}$ \\
\hline Steel Primer & Amerlock 400 \\
\hline Concrete Surfacer & Nu-Klad 114A \\
\hline Concrete Primer (walls) & $\begin{array}{c}\text { Nu-Klad 105A or } \\
\text { Amerlock 400 }\end{array}$ \\
\hline Concrete Primer (floors) & Nu-Klad 105A \\
\hline Base Coating & Amerlock 400 \\
\hline Intermediate Finish Coating (except floors) & Amerthane 487 \\
\hline Self-Leveling base (floors only) & PSX 756 Siloxane \\
\hline Top Coat (floors only) & PSX 756 Siloxane \\
\hline
\end{tabular}

\section{DIVISION 13 - SPECIAL CONSTRUCTION}

\section{Section 13440 Instrumentation}

1. Programmable Logic Controller (PLC): Series TSX Quantum Automation, Modicon/Square D.
a. PLC: 140 CPU 42402 Controller.
b. PLC backplane: 140 XBP 01600 sixteen slot backplane.
c. PLC power supply: 140 CPS 214 O0 DC power supply.
d. Remote I/0 controller: 140 CRP 93200 remote I/0 head. 
e. Remote I/0 drop card: 140 CRA 93200 remote drop input.

f. Remote I/0 cable tap: MA 0185000 .

g. Remote backplane: 140 XBP 01600 sixteen slot backplane.

h. Remote I/0 power supply: 140 CPS 21400 DC power supply.

i. PLC software program: SW-MSID-9LA (site 1icense Modsoft).

j. Communication network: Modbus Plus.

k. Communication card: AM-SA85-002 IBM PC/AT Adaptor.

1. TCP/IP interface card: SW-EMBP-000 Ethernet to Modbus Plus Gateway.

m. Analog input card: 140 AVI 03000 (8 channels, unipolar).

n. Discrete output card: 140 DRC 83000 relay (NO/NC] 8 output points form $C$.

o. Discrete input card: 140 DAI 540 00 115 Vac isolated input module; 16 points.

p. RTD input card: 140 ARI 030008 channels.

2. Man-Machine-Interface (MMI): Modicon Modular FactoryMate Plus Series; industrial PC.
a. CRT: 19 inch $1280 \times 1024$ resolution (with ISA SVGA video board).
b. Processor: 80486DX; $66 \mathrm{MHz}, 16 \mathrm{MB}$ RAM.
c. Hard disk: $240 \mathrm{MB}$.
d. Operator interface: Basic keypad with industrially sealed mouse installed.
e. Software: FactoryLink.

3. Tank level measurement:
a. ENRAF displacement level gauge Model 854ATG.
b. ENRAF communications interface unit Model CIU 858.

4. Liquid conductivity probes: Double metallic probe used for conductivity measurement.

5. Tank temperature: Temperature tree, see Hanford Drawings $\mathrm{H}-2-815180, \mathrm{H}-2-815781$, and $\mathrm{H}-2-817863$. 
6. Tank pressure: Differential pressure tranșitter, Rosemount 3051C.

7. Waste monitoring: Magnetic flowmeter, Fischer and Porter, Model 1001475, Class 1, Division 2 approved.

8. Raw water monitoring: Turbine flowmeter, EG\&G series FT with 100:1 turndown and series "RI5x" rate indicator/transmitter. 1-1/2 inch range $=1.6$ to $160 \mathrm{gpm}$ or 2 inch range $=2.5$ to $250 \mathrm{gpm}$.

9. Annulus CAM leak detector: Eberline AMS-4.

10. Primary exhaust pressure: Differential Pressure Indicating/Transmitter (PDIT): Bailey Model BCN-11 or BCN-12.

11. Primary exhaust temperature: Temperature Indicating Transmitter (TIT): Foxboro 893 series RTD with integrally mounted element and local display.

12. Exhaust stack monitoring: A Gaseous Effluent Monitoring System (GEMS) stack monitor specification for multiple tank farms is under development by WHC (see WHC Specification WHC-S-0400).

13. Enclosures and accessories:

a. Hoffman, instrument enclosure Model A-36H3OFLP; NEMA 4.

b. Hoffman heater Model D-AH4001B; 400 watt, $115 \mathrm{~V}$.

Section 13460 Gamma Radiation Nonitoring System

1. Leak detection pit:

a. Submersible gamma probe, Series DT-616W, Nuclear Research corp.

b. Gamma radiation meter, Model ADM-610, Nuclear Research Corp; NEMA 4.

2. Raw water backflow:

a. Liquid radiation monitor, Victoreen model 940-3.

b. Digital ratemeter, Victoreen model 942A-200.

\section{DIVISION 15 - MECHANICAL}

\section{Section 15493 Chemical Process Piping Systems}

\section{A. Process and Service Piping}

1. Process piping shall meet the requirements for design, materials, fabrication, erection, testing, and inspection as prescribed by ASME B31.3. Material requirements, piping categories (ASME B31.3 
categories), inspection/testing, non-destructive examination (NDE) and material documentation requirements are listed on the pipe code descriptions. Valves shall be consistent with the ratings of the fittings.

2. Support material shall be as follows.

a. Carbon steel: ASTM A 36.

b. Stainless steel: ASTM A 276, Type 304 or 304L.

3. Cathodic protection system shall be provided on buried metallic process, drain, and ventilation piping.

4 Protective coating for piping in contact with earth or concrete shall be as follows:

a. Carbon steel piping: Factory-applied exterior protective coating in accordance with AWWA C2.3.

b. Carbon steel piping special sections, connections and fittings: Field applied liquid epoxy coatings and hot melt patch compound, SCOTCHKOTE 312 and $206 \mathrm{~N}$, respectively.

c. Stainless steel pipe: Extruded polyethylene, by Encoat a Lukens Company. (Thickness based on pipe size, 25-40 mil)

5. Flush piping with water after installation.

6. Identify exposed piping as to fluid carried and direction of flow in accordance with ANSI Al3.1.

7. The following piping systems will be installed to withstand natural forces requirements for nonreactor facilities as specified in Hanford Plant Standard SDC 4.1.

a. Moderate Hazard (Safety Class 2)

Primary Ventilation piping (M-9)

Waste Transfer piping (M-9)

Drain piping (M-9)

Piping Encasement (M-26)

b. Low Hazard/Important (Safety Class 3)

Annulus Ventilation piping (M-9)

Piping not identified above.

8. Jumpers will be designed in accordance with WHC-SD-RE-DGS-002, Rev. 3, to connect each active pit nozzle to the valve manifolds. Jumpers will use Integral Seal Block-type connectors and satisfy Safety Class 3 requirements. 
B. Equipment

1. Seal pot

a. 180 gallon capacity stainless steel (304L) tank, 42 inches diameter by 30 inches tall. The tank will be designed, fabricated and code stamped in accordance with ASME Section VIII, Division 1.

b. Tank Liquid Level will be monitored with a level element which will be removed remotely and installed with a jumper assembly.

c. Liquid level will be maintained by manually adding water through a fill funnel and shutoff valve located adjacent to the pit.

2. Seal pot pit sump pump

a. Self priming centrifugal pump, $1 / 3$ horsepower, 1-phase, $60 \mathrm{~Hz}$, $115 / 230 \mathrm{~V}$.

Section 15500 Heating, Ventilating, and Air Conditioning

A. Materials

1. Plenums: Stainless steel sheet - ASTM A 240, Type 304 or $304 \mathrm{~L}$.

2. Plenum reinforcement:

a. Stainless steel sheet: ASTM A 240, Type 304 or $304 \mathrm{~L}$.

b. Stainless steel shapes: ASTM A 276, Type 304 or 304L.

3. Supports:

a. Carbon steel shapes: ASTM A 36.

b. Stainless steel shapes: ASTM A 276, Type 304 or 304 L.

4. Insulation: UL listed in the Building Materials Directory, and carry UL mark.

a. Insulation and adhesive shall have UL fire hazard classifications of 25 maximum for $\mathrm{fl}$ ame spread and 50 maximum for smoke developed.

b. Insulation for exterior surfaces of plenums and filter housings: $1-1 / 2$ inch thick glass fiberboard, $6 \mathrm{lb} / \mathrm{ft}^{3}$ minimum density; Schuller Spin-Glas board.

5. Ventilation piping: Exhaust piping will be in accordance with pipe code M-9. Primary ventilation underground ductwork will be double contained in accordance with pipe code M-26. Fabrication and 
testing will be in accordance with ASME N509/N510 or ASME AG-1 as applicable.

6. Fabricate and install piping in accordance with ASME B31.3.

7. Protective coating for piping in contact with earth or concrete.

a. Carbon steel piping: Factory applied exterior protective coating; AWWA C203.

b. Carbon steel piping special sections, connections, and fittings: Field applied exterior protection system, AWWA C203, Section 3; Tapecoat Company "Tapecoat 20" and primer.

c. Stainless steel pipe: Extruded polyethylene, by Encoat a Lukens Company. (Thickness based on pipe size, 25-40 mil)

8. Underground pipe trenching: Excavate, backfi11, and compact.

B. Equipment

1. Exhaust fans: Centrifugal, stainless steel, non-sparking wheel, arrangement 9. Fans will be designed in accordance with ASME N509 and furnished with radial vane inlet dampers or variable speed drives (as shown), back-draft dampers, and vibration isolation mounts. Motors will be furnished in accordance with NEMA MG-1 and have a premium efficiency classification. See equipment schedule.

2. HEPA filter housings will be bag-in/bag-out arrangement with HEPA filter test sections or test ports as shown. HEPA filter housings will be capable of meeting test requirements of ASME N510. Housings will meet the requirements of ASME N509. See equipment schedule.

3. HEPA filters will have metal frames and meet the requirements of ASME AG-1.

4. Heating coils at the filter trains will be fin-tubular construction, non-sparking design, with proportional solid state controllers that hold a constant temperature or temperature rise with varying air flows. The heating element to flange penetrations will be sealed, meeting the pressure decay test requirements of ASME N510. Heating coils will meet the requirements of ASME N509. SCR unit with fused disconnect switch shall be outdoor type in NEMA 4 enclosure. See equipment schedule.

5. Prefilters will be 50 percent ASHRAE Standard 52 rated, UL Class 1 . Prefilter housings will be a bag-in/bag-out arrangement.

6. Carbon adsorber housings will be located in the air clean-up trains between the HEPA filters. Housings will be bag-in/bag-out arrangement, meeting the requirements of ASME N 509 and $N 510$. 
7. Mist eliminators: Designed for horizontal airflow at velocities not to exceed $600 \mathrm{fpm}$. The mist eliminators shall consist of a blade deentrainment section followed by a 4 inch thick sst fine mesh pad, followed by an array of spray nozzles (for pad cleaning), followed by a downstream blade deentrainment section.

\begin{tabular}{|c|c|c|c|c|c|}
\hline \multicolumn{6}{|c|}{ EQUIPMENT SCHEDULE } \\
\hline \multirow{2}{*}{$\begin{array}{l}\text { Tank Farm } \\
\text { System }\end{array}$} & \multicolumn{3}{|c|}{ Fans } & \multirow{2}{*}{$\begin{array}{l}\text { HEPA Filters } \\
\text { Configuration }\end{array}$} & \multirow{2}{*}{$\frac{\text { Elec. Heaters }}{\text { Capacity (kW) }}$} \\
\hline & $\begin{array}{l}\text { Flow } \\
\text { (cfm) }\end{array}$ & $\begin{array}{c}\Delta \mathrm{P} \\
\text { (in. } w c)\end{array}$ & $\begin{array}{l}\text { Motor } \\
\text { (hp) }\end{array}$ & & \\
\hline AN (Pri.) & 1500 & 10 & 7.5 & $2 \times 1,24 \times 24 \times 11\}$ & 10 \\
\hline AP (Pri.) & 2000 & 11 & 7.5 & $2 \times 1,24 \times 24 \times 11 \frac{1}{2}$ & 10 \\
\hline AW (Pri.) & 2000 & 11 & 7.5 & $2 \times 1,24 \times 24 \times 11 \xi$ & 10 \\
\hline SY (An. Ex.) & $\begin{array}{c}600 \\
(2 \mathrm{ea})\end{array}$ & 12.5 & 3 & $1 \times 1,24 \times 24 \times 11 \frac{1}{2}$ & \\
\hline SY (An. Sup.) & & & & $1 \times 1,24 \times 24 \times 11 \frac{1}{2}$ & 1 (2 ea. Tank) \\
\hline 244-A DCRT & 175 & 12 & 1 & $1 \times 1,12 \times 12 \times 11 \frac{1}{2}$ & $\begin{array}{c}2 \text { (supply) } \\
1.5(\text { exh) }\end{array}$ \\
\hline 244-S DCRT & 175 & 12 & 1 & $1 \times 1,12 \times 12 \times 11 \frac{1}{2}$ & 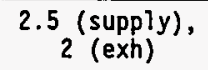 \\
\hline
\end{tabular}


C. Pipe Codes

The pipe codes are as follows:

\begin{tabular}{|c|c|c|}
\hline \multicolumn{3}{|c|}{ PIPE CODE $M-9$} \\
\hline $\begin{array}{l}\text { Service } \\
\text { Waste Transfer }\end{array}$ & $\begin{array}{l}\text { Max. Operating Pressure } \\
400 \text { psig }\end{array}$ & $\begin{array}{l}\text { Max: Operating Temp } \\
200^{\circ} \mathrm{F}\end{array}$ \\
\hline Ventilation & $+60 /-6$ inH $_{2} \mathrm{O}$ & $200^{\circ} \mathrm{F}$ \\
\hline Drains & 20 psig & $200^{\circ} \mathrm{F}$ \\
\hline Sizes & $10^{\prime \prime}$ and smaller. & $12 "$ and larger \\
\hline Pipe & \multicolumn{2}{|c|}{ ASTM A 312 Grade TP $304 L$ Seamless } \\
\hline Wall Thickness & Schedule $40 \mathrm{~S}$ & Standard Weight \\
\hline Fittings & \multicolumn{2}{|c|}{$\begin{array}{l}\text { Stainless steel, ASTM A } 403 \text { Grade WP-S } 304 \mathrm{~L} \text {, buttwelding } \\
\text { in accordance with ASME B16.9. Wall thickness to match } \\
\text { pipe }\end{array}$} \\
\hline Flanges & \multicolumn{2}{|c|}{$\begin{array}{l}\text { Class } 300 \text { forged stainless stee), ASTM A } 182 \text { Grade F } 304 \mathrm{~L} \text {, } \\
\text { raised face, weld neck in accordance with ASME BI6.5. } \\
\text { Bore to match pipe ID. (No buried flanges) }\end{array}$} \\
\hline Bolting & \multicolumn{2}{|c|}{$\begin{array}{l}\text { Alloy steel bolts, ASTM A } 193 \text { Grade } B 7 \text {, and heavy hex } \\
\text { nuts, ASTM A } 194 \text { Grade } 2 H \text {. }\end{array}$} \\
\hline Gaskets & \multicolumn{2}{|c|}{$\begin{array}{l}\text { Compressed carbon fiber, nonasbestos, } 1 / 16 " \text { thick sheet; } \\
\text { Garlock HTC } 9850 \text {, or Anchor Packing } 495 \mathrm{C} \text {. Use full face } \\
\text { gaskets with flat face flanges. }\end{array}$} \\
\hline Valves & \multicolumn{2}{|c|}{$\begin{array}{l}\text { Class } 300 \text {, stainless steel body, ASTM A } 351 \text { Gr. CFBM, } \\
\text { butt-we1d ends, UHMWPE seats and seals. } \\
\text { 2-Way: PBM SP-H-39-BW-S-6 } \\
\text { 3-Way: PBM MP-H-19-BW-S-6 }\end{array}$} \\
\hline $\begin{array}{l}\text { Installation: } \\
\text { NDE Requirement }\end{array}$ & \multicolumn{2}{|l|}{ ASME B31,3, Normal Service } \\
\hline
\end{tabular}




\begin{tabular}{|c|c|c|}
\hline \multicolumn{3}{|c|}{ PIPE CODE $\mathrm{N}-26$} \\
\hline $\begin{array}{l}\text { Service } \\
\text { Encasement }\end{array}$ & $\begin{array}{l}\text { Max. Operating Pressure } \\
\text { Same as encased line }\end{array}$ & $\begin{array}{l}\text { Max. Operating Temp } \\
\text { Same as encased line }\end{array}$ \\
\hline Sizes & 10" and smaller & $12^{\prime \prime}$ and larger \\
\hline Pipe & \multicolumn{2}{|l|}{ ASTM A 106 Grade B } \\
\hline Wall Thickness & Schedu7e 40 & Standard Weight \\
\hline Fittings & \multicolumn{2}{|c|}{$\begin{array}{l}\text { Wrought steel, ASTM A } 234 \text { Grade WPB, buttwelding in } \\
\text { accordance with ASME B16.9. Wall thickness to match pipe. }\end{array}$} \\
\hline Flanges & \multicolumn{2}{|l|}{ None } \\
\hline Bolting & \multicolumn{2}{|l|}{ None } \\
\hline Gaskets & \multicolumn{2}{|l|}{ None } \\
\hline $\begin{array}{l}\text { Installation: } \\
\text { NDE Requirement }\end{array}$ & \multicolumn{2}{|l|}{ ASME B31.3, Normal Service } \\
\hline
\end{tabular}




\section{DIVISION 16 - ELECTRICAL}

\section{Section 16300 Medium Voltage Distribution}

\section{A. Material}

1. Underground conduit: Rigid steel or PVC in concrete duct bank; or PVC coated rigid steel or Schedule 80 PVC direct buried.

2. Primary cable: $15 \mathrm{kV}$ single conductor for wet and dry conditions at normal operating temperature of $90^{\circ} \mathrm{C}$ maximum.

a. Conductor: Copper, annealed, class B concentric stranding.

b. Conductor shield: Extruded semi-conducting thermosetting compound, 15-mils thick minimum.

c. Insulation: Ethylene-propylene-rubber, 220-mils thick minimum.

d. Insulation shield: Minimum 30-mil extruded nonmetallic covering over insulation with minimum 5-mil nonmagnetic metal component directly over or embedded in covering.

e. Jacket: Black polyethylene, 80-mils average minimum thickness.

B. Equipment

1. Equipment enclosures: NEMA ICS 6 Type 3R minimum.

2. Distribution power fuse: Drop out, 45 degree open power fuse disconnect, Extra-heavy-duty minimum 22,400 amperes asymmetrical interrupting rating at $14.4 \mathrm{kV}$. Fuse-unit rating as shown on the drawings. Fuses will be furnished and installed by Operating Contractor.

3. Lightning arresters: Metal-oxide distribution type rated $18 \mathrm{kV}$, $125 \mathrm{bil}$, for use on $13.8 \mathrm{kV}$ grounded-neutral system. Porcelain bodies, wet porcelain with uniform color glaze. Galvanized cap and base hardware with bolted clamps for both line and ground connections. Galvanized mounting bolts.

4. Distribution transformers: Outdoor type, ratings as shown on the Figures, and have two $2-1 / 2 \%$ above and below normal high-voltage taps, pad-mounted with less flammable cooling and insulating fluid. Transformers shall have outdoor type non-fused 3-phase gang-operated load break switch for incoming $13.8 \mathrm{kV}$ lines. 


\section{Section 16400 Service and Distribution}

A. Materials

1. Conduit:

a. Conduit below grade: PVC coated rigid steel or schedule 80 PVC buried 12 inches minimum inside tank farms and 24 inches minimum outside tank farms.

b. Exposed conduit: Rigid steel, intermediate metal conduit (IMC), or electrical-metallic tubing (EMT).

c. Conduit concealed in concrete: PVC

2. Conductors: $600-\mathrm{V}$ insulated, type THHN/THWN or XHHW stranded copper.

B. Equipment

1. Equipment enclosures: NEMA ICS 6, Type 12 inside building and Type 4 outside building.

2. Motor control centers (MCC): 20-inch deep enclosure for control equipment, assembled to provide dead-front unit. Incoming feeders shall enter from bottom. Size feeder terminal lugs to accept conductors specified.

a. Motor controllers: Horsepower rated with 2 NO and 2 NC auxiliary contacts. Provide compartments with equipment shown on the Drawings.

b. Locate master terminal boards in bottom of sections.

c. Provide neutra1 bus sized to $100 \%$ of the phase buses.

d. Feeder circuit breakers: Molded case circuit breakers, 3-phase, individually mounted in a drawout type cubicle, trip free, rated for use at $600 \mathrm{~V}$ ac. Interrupting rating: $50,000 \mathrm{AIC}$ symetrical at $480 \mathrm{~V}$ ac. For ampere frame and trip ratings for the individual breakers see one-line diagram.

3. Panelboards: UL labeled, surface mounting, rated as shown on the Figures with main circuit breaker.

a. Provide doors with flush-type combination catch and locks, keyed alike and furnished with 2 keys for each panelboard. Provide each panelboard with directory card holder and card for branch circuit load identification. 
b. Branch circuit breakers: Molded case bolt-on type, with thermal magnetic trips. Number, rating, and arrangement are shown on the Figures.

1) Permanently number branch circuits. Number tabs shall not be attached to, or be part of, circuit breaker.

2) Branch circuit breaker positions marked "space": Bussed for future circuit breakers. Provide removable single pole filler plates for spaces shown on the Figures.

4. Combination motor controllers: Horsepower rated, with 2 NO and 2 NC auxiliary contacts. Bimetallic type overload elements are acceptable. Overload relay reset in cover. Instantaneous motor circuit protector type circuit breakers. Enclosure NEMA type as shown on Drawings.

5. Safety switches: Outdoor type in NEMA $3 R$ raintight enclosure, Non-fused heavy duty Type with ratings as shown on Drawings complete with ground bus. Surface mounted.

6. Enclosed combination magnetic starter: Outdoor type, NEMA 4 raintight enclosure, rated as shown on Drawing, complete with combination type starter with circuit breaker rated for $600 \mathrm{~V}$ ac 3-phase, $60 \mathrm{~Hz}$; control transformer rated 480-120 V, 1-phase, $60 \mathrm{~Hz}$; coil rated $120 \mathrm{~V} \mathrm{ac}$, and start/stop pushbuttons and red indicating light wired and mounted on front door. Surface mounted.

7. Variable speed drive: Adjustable frequericy controllers to provide continuous speed adjustment for standard 3-phase squirrel cage induction motors, capable of independently controlling the pump between 25 and 100\% of full rated speed. Horsepower ratings shown on One-Line Diagrams. Drives enclosure shall be NEMA Type 12 for surface-mounting.

8. Mini-power center: Outdoor type, NEMA 4 raintight enclosure, with primary and secondary main breakers and branch circuit breakers with thermal magnetic trips and ground bus. Suitable for surface mounting. Ratings as shown on Drawings.

9. Manual transfer switch: Outdoor type, NEMA 4 raintight enclosure, heavy duty type, non-fused, 3-pole, double throw with rating as shown on Drawing, complete with grounding lug. Surface mounted.

10. Wire gutter: Outdoor type in NEMA 4 raintight enclosure suitable for surface mounting.

11. Power receptacle: Weatherproof back box and angle adaptor, heavy duty with ratings as shown on Drawing, self-closing spring doors on receptacle and cord connectors with environmental sealing. Surface mounted. 
12. Receptacle switch: Outdoor type in NEMA 4 raintight enclosure, fusible with ratings as shown on Drawing. Surface mounted.

13. Enclosed circuit breaker: Outdoor type in NEMA 4 raintight enclosure, molded case with thermal magnetic trip with ratings as shown on Drawing. Surface mounted.

14. SCR unit: Outdoor type in NEMA 4 raintight enclosure, rated for $480 \mathrm{~V} \mathrm{ac}$, 3-phase, $60 \mathrm{~Hz}$ complete with main disconnect switch, fused control power transformer, 4-20 mA current input/output power "on" pilot light. Heater $\mathrm{kW}$ rating as shown on Drawings.

15. Circuit breaker: Molded case circuit breaker with thermal magnetic trip, ratings as shown on Drawing.

16. Receptacles: $120 \mathrm{~V}$ ac convenience duplex receptacles in outdoor type raintight enclosure.

17. Heat trace cable: Self-regulating heating cable rated $5 \mathrm{~W} / \mathrm{ft}, 120$ $\checkmark \mathrm{ac}$, bus wire gauge No. 16 AWG with semi-conductive polymer core and flame-retardant jacket.

18. Heat tracing control panel: Outdoor NEMA Type 4 enclosure with current sensing devices, relays, and indicating lights for $120 \mathrm{~V}$ ac application.

\section{Section 16640 Cathodic Protection}

1. Anodes: High-silicon chromium iron, 2 inch diameter by 24 inches long, 13 lbs, prepackaged in an 8 by 48 -inch steel canister with coke breeze backfill; No. 8 AWG lead wire with HMW/PE insulation, $50 \mathrm{ft}$ in length. Durichlor 51 Anode Co., Type TAB.

2. Permanent reference electrode: Saturated gelled copper-copper sulfate with 20 feet of No. 8 AWG lead wire with HMW/PE insulation, 30 year minimum design life. Electrochemical Devices, Inc., Model UL-CUG-LWO2O.

3. Test stations: High impact plastic housing, removable 9 point terminal board, removable cover. Street Fink CP Test Station manufactured by Cott $\mathrm{Mfg}$. Co.

4. Anode distribution box: $12 \times 12 \times 6$-inch with 32 solderless pressure type terminals, Goodall, Model No. T-32-A.

5. Conduit:

a. Rigid stee], PVC coated (anode distribution box).

b. PVC, Schedule 40, 6-inch (for use with test stations). 
6. Conductors:
a. No. 8 AWG, stranded copper cable, HMW/PE insulation (pipe test conductors).
b. No. 4 AWG, stranded copper cable, HMW/PE insulation (pipe jumpers).
c. 2/0 AWG stranded copper cable, HMW/PE insulation (anode feeder, loop and negative return cables).

7. Exothermic weld mold: Low emission type or standard type (for connection of test conductors, jumpers and negative return cables).

8. Exothermic weld metal: Low emission type or standard type.

9. Conductor splice kit: For underground use (anode lead to anode header cable), 3M Scotchcast Brand, Catalog No. 82-Bl or 90-Bl.

10. Wiremarkers: Plastic tag type, typewritten.

11. Cable marker: Metal auger flush with grade type, 17 inches long, 6 -inch diameter identification area with raised words "CATHODIC PROTECTION"; A.B. Chance Co., Catalog No. C554-0001 with installation tool No. CWFA.

12. Nameplate: Survey marker type, brass, 2-inch diameter (for use with test stations). Surveyors Service Company No. 2132. 


\section{APPENDIX F}

Energy Conservation Report and Analysis 


\section{ENERGY CONSERVATION REPORT AND ANALYSIS}

Energy reporting requirements and equipment designs shall be in accordance with DOE Order 6430.1A.

All energy consumption resulting from project $W-314$ is due to process equipment. There are no new buildings.

Each tank farm is metered separately for power consumption, and is considered as an individual facility. The increase in energy consumption in each facility is well below 500 million BTU/yr.

Differences in energy consumption due to this project are accounted for in the ventilation systems for Tank Farms 241-AN, -AP, -AW, and -SY. Although the 244-A and -S DCRTs ventilation systems will be replaced, the normal operating loads will be unchanged and therefore the energy consumption will not be noticeably affected.

Changes in system design due to project W-314 will affect the power consumption of the exhaust fan motors and the filter train heaters. All new motors will be specified with premium efficiency motor classification. All new electric heaters will use SCR controls to avoid excessive energy consumption. Following is a summary of energy consumption differences for each facility:

\section{1-AN Tank Farm}

An increase in the average flow rate from $600 \mathrm{cfm}$ to $1000 \mathrm{cfm}$ will increase the exhaust fan consumption by $44,588,000$ Btu/yr. The filter train heater consumption will increase by $37,843,000 \mathrm{Btu} / \mathrm{yr}$.

Total energy increase $=82,431,000 \mathrm{Btu} / \mathrm{yr}$. 


\section{1-AP Tank Farm}

An increase in the average flow rate from $1170 \mathrm{cfm}$ to $1500 \mathrm{cfm}$ will increase the exhaust fan consumption by $25,192,000$ Btu/yr. The filter train heater consumption will increase by $31,221,000$ Btu/yr.

Total energy increase $=56,413,000 \mathrm{Btu} / \mathrm{yr}$.

\section{1-AW Tank Farm}

An increase in the average flow rate from $1000 \mathrm{cfm}$ to $1500 \mathrm{cfm}$ will increase the exhaust fan consumption by $80,259,000 \mathrm{BTU} / \mathrm{yr}$. The filter train heater consumption will increase by $47,304,0008 \mathrm{TU} / \mathrm{yr}$.

Total energy increase $=127,563,000 \mathrm{BTU} / \mathrm{yr}$.

\section{1-SY Tank Farm}

The annulus system flow will be increased from an average of $600 \mathrm{cfm}$ to $750 \mathrm{cfm}$, which will increase the fan consumption by $26,753,000 \mathrm{BTU} / \mathrm{yr}$. The new annulus exhaust will not have a heater, however, there will be a heater in the supply where none exists now. The net effect will be a reduction in heater energy consumption of 27,216.000 BTU/yr.

Total energy decrease $=463,000 \mathrm{BTU} / \mathrm{Yr}$. 
Project Title: TANK FARA RESTORATION 2 SAFE OPERATIONS

Project Location: 241-All $200 E$

Cateqory Type(s)/Cateqory Description(s):

Prolected Base Case Annul Energy Usage (Btu/ft't/yr): Start Date:

ENTILATION UPGRADE

Total Floor Area $\left(f t^{2}\right)$ : $n / A$

Est inated Project Budget (thousand S): TBD

Reporting Approsch:

D] Direct

Q Short form, complete form ECH-S-1

0 integrated, conplete Form ECM-1-1

D Phese

(See table 1 for complience form descriptions.)

Prescriptive Method: (See table 2 for checklist and worksheet descriptions.) M/A

Interior Lighting $\mathbf{3 . 3 . 4}$

Dexterior Lighting 3.3.4

Q Building Envelope 3.5.4

[ HVAC Systems $\mathbf{3 . 7 . 4}$

0 Service Water Hesting 3.9 .6

D Other Energy-Using Systems 3.13 .4

System Performence Methed: (See table 2 for checklist and worksheet descriptions.) $M / A$

D Lighting Interior $\mathbf{3 . 3 . 4}$

D Lighting Exterior 3.3.5

O Building Envelope 3.5 .5

O Other Energy-Using Systens 3.13 .4

Compliance Alternotive Method: (See table 1 for compl iance form descriptions.) W/A

[] Building Energy Cost

0 Building Energy Use

0 Life-Cycle Cost Anslysis Complete Form ECM-BEC-3.11 Complete Form ECM-BEU-3. Conplete Form ECH-LCCA-3.14 Computer Software Used/Version: D EWVSTD Version D LTGSTO Version W/A Building Simulation Program (DOE, BLAST, ASEAM, etc.): Version N/A

Life-Cycle Cost Analysis Progrem Used: C [X] BLCC Version 4.11 D Other Version

Apolications for Variance Required? $D$ Yes $[X]$ Ho if yes, attach form ECM-V+1 for each. Comisstoning of HVAC equipment required? $]$ Yes $[X]$ No if yes, attach comissioning report.

Acceptance tests been performed? $D$ Yes $[X]$ No if yes, attach Form ECM-AT.

Uinter performance tests been performed? $\square$ Yes $[X]$ No If yes, attach form ECM-PT- $W$.

Sumber performance tests been performed? $Q$ Yes $[X]$ No if yes, attach form ECM-PT-S.

Private Sector Energy Experts Design Review Required? $D$ Yes $[X]$ No If yes, attach Form ECM $R-1$.

Existing Building Energy Survey Required? Q Yes [X] wo If yes, ettach form ECM-ES-3.15. 
Project Title: IANK FARM RESTORATION \& SAFE OPERATIONS

Prolect Location: 249-AP 200E

Catepory Type(s)/Category Description(s):

Projetted Base Case Annul Energy Usage (Btu/ft'/(r):

Total floor Ared $\left(\mathrm{ft}^{2}\right)$ : W/A

Estinoted Project Budpet (thousand \$): TBD

Reporting Approseh:

DJ Direct

D short form, complete Form ECA-S-1

D Integrated, complete Form ECM-I-1

Q Phase

(See table 1 for compliance form deseriptions.)

Prescriptive Method: (See table 2 for checkl ist and worksheet descriptions.) H/A
D Interior Lighting $\mathbf{3 . 3 . 4}$
0 Exterior Lighting $\mathbf{3 . 3 . 4}$

D Building Envelope 3.5.4

D HVAC systems 3.7 .4

0 Service Hater Heating $\mathbf{3 . 9 . 4}$

D other Energy-Using Systems 3.13 .6

System Performance Method: (See table 2 for checklist and worksheet descriptions.) $\mathrm{M} / \mathrm{A}$

D Lighting Interior 3.3 .6

D Lighting Exterior 3.3.5

0 Building Envelope 3.5.5 0 Other Energy-Using systems 3.13.4

Compl iance Alternative Method: (See table 1 for conpl lance form descriptions.) N/A

o Building Eneroy cost

O Building Energy Use

Life-Cycle Cost Analysis

Complete Form ECM-BEC-3.19 Complete Form ECM-BEU-3.

Computer Sof tware Used/Version: $\square$ ENVSTD Version

Building simulation Program (DOE, BLAST, ASEAM, etc.):

Life-Cycle Cost Analysis Progran Used: $[X]$ BLCC Version $4.11 \quad$ D Other

Complete form ECH-LCCA-3.14

Version N/A

Applications for Voriance Required? $D$ Yes $[X]$ No if yes, attach form ECH-V- 1 for each.

Commissioning of HVAC equipment required? $D$ Yes $X 1$ Ho if yes, attach commissioning report.

Acceptance tests been performed? $D$ Yes [X] No If yes, at tach Form ECM-AT.

Winter performance tests been performed? $D$ Yes $[X]$ No If yes, ottach Form ECM-PT-W.

Sumer performance tests been performed? $Q$ Yes $[X]$ No If yes, attach form ECM-PT- $S$.

Private Sector Energy Experts Design Review Required? $D$ Yes [X] No if yes, attach Form ECM-R-1.

Existing Building Energy Survey Required? a res [x] No If yes, attach Form ECH-E5-3.15. 
Project Title: TAUK FARH RESTORATIOH \& SAFE OPERATIONS

Project Location: 261-AW 200E

Category Type(s)/Catepory Deseription( $s$ :

Projected Base Case Annul Energy Usage (Btu/ft $\mathrm{t}^{2} / \mathrm{yr}$ ):

Total Floor Ares $\left(f t^{2}\right)$ : W/A

Est imsted Project Budget (thousand 5 ): TBD

Reporting Approsch:

[x] Direct

Short form, complete form ECN-s-1

D integrated, complete form ECH-1-1

D Phase

(See table 1 for comoliance form descriptions.)

Prescriptive Method: (See table 2 for checkl ist and worksheet descriptions.) $\mathrm{N} / \mathrm{A}$

0 Interior Lighting $\mathbf{3 . 3 . 4}$

D Exterior Lighting $\mathbf{3} .3 .4$

D Building Envelope 3.5.4

D HVAC Systems 3.7 .6

0 Service Hater Heating 3.9 .4

0 other Energy-Using Systeas 3.13 .4

System Performance Method: (See toble 2 for checklist and worksheet descriptions.) $N / A$

0 Lighting Interior 3.3 .4

D Lighting Exterior 3.3.5

$\square$ Building Envelope 3.5 .5

O Other Energy-Using Systems 3.13 .4

Compl iance Al ternative Hethod: (See toble I for compliance form descriptions.) N/A

[] Building Energy Cost

$\square$ Building Energy Use

Life-Cyele Cost Analys is

Complete Form ECM-BEC-3.11 Comolete form ECM-BEU-3.

Conouter Software Used/version: $\mathrm{I}$ EWVSTD Version

Life-Cycle Cost Analysis Progren Used:

(x) etc.):

[X] BLCC Version 4.11

LTGSTD Version N/A

Complete Form ECM-LCCA-3.94

Dother

N/A

Applications for Variance Required? $]$ Yes [X] No If yes, attach Form ECM- $V$ - 1 for each.

Commissioning of BVAC equipment required? $D$ Yes $[x]$ No If yes, attach commissioning report.

Acceptance tests been performed? $D$ Yes $[X]$ No If yes, attach Form ECM-AT.

Hinter performance tests been performed? $Q$ Yes $[X]$ No If yes, attach Form ECM-PT-H.

sumer performance tests been performed? 0 Yes $[X]$ No If yes, at tach Form ECM-PT-S.

Private Sector Energy Experts Design Revien Required? $Q$ Yes [X] No if yes, attach Form ECM-R-1.

Existing Building Energy Survey Required? $\square$ Yes [X] No If yes, attach form ECH-ES-3.15. 
Projet Title: TAMK FARM RESTORATION \& SAFE OPERATIONS

Project Location: 241-SY 200E

Cateoory Type(s)/Cotegory. Description(s):

Projected Base Case Anmul Energy Usage (Btu/ft'/yr):

Total floor Aree (ft'): W/A

Estinated Project Budget (thousand S): TBD

Reporting Approsch:

D] Direct

D short form, complete form ECM-5-1

0 Integrated, conolete Form ECH-1-1

D Phase

(Sese toble 1 for conpliance form descriptions.)

Prescriptive Method: (See table 2 for checklist and worksheet descriptions.) N/A

D Interior Lighting $\mathbf{3 . 3 . 4}$

D Exterior Lighting 3.3 .6

] Building Envelope 3.5 .4

D HVAC Systems $\mathbf{3 . 7 . 6}$

D Service Water Heat ing 3.9 .4

$\mathrm{B}$ other Energy-Using Systems 3.13 .4

Sycten Performence Method: (See table 2 for checkl ist and worksheet descriptions.) N/A

0 Lighting Interior 3.3 .4

D Lighting Exterior $\mathbf{3 . 3 . 5}$

$\square$ Building Envelope 3.5.5

0 Other Energy-Using Systens 3.13 .4

Compliance Alternative Method: (See toble 1 for compliance form descriptions.) N/A

[] Buil lding Energy Cost

a building Energy Use

0 Life-Cycle Cost Analysis

Complete Form ECM-BEC-3.11 complete Form ECM-BEU-3. Complete Form ECM-LCCA-3.14

Computer Software Used/Version: $\square$ ENVSTO Version $\mathrm{D}$ LTGSTO Version N/A

Building Simulation Progren (DOE, BLAST ASEAM, etc.): Version N/A

Life-Cycle Cost Analysis Program Used: $[X]$ BLCC Version 4.11 D other version

Apol ications for Variance Recuired? $D$ Yes $[X]$ No If yes, attach Form ECM-V+1 for each.

Commissioning of HVRC equipment required? $\square$ Ves $[X]$ No if yes, attach comissioning report.

Acceptance tests been performed? $Q$ Yes $[X]$ No if yes, attach Form ECM-AT.

Winter performance tests been performed? 0 Yes $[X]$ No if yes, attach Form ECM-PT-W.

Sumer performance tests been performed? $D$ Yes $[X]$ No If yes, attoch Form ECM-PT-S.

Private Sector Energy Experts Design Review Required? $Q$ Yes $[X]$ No If yes, attach Form ECM-R-1.

Existing Building Energy Survey Required? $\square$ Yes [X] No If yes, attach Form ECM-ES-3,15. 


\section{APPENDIX G}

Physically Handicapped Assessment

(Provided by Operating Contractor) 


\section{ACCOMMODATIONS OF PHYSICALLY HANDICAPPED}

PROJECT NO. W-314

PROJECT TITLE Tank Farm Restoration and Safe Operations

LOCATION 200 East and West

BUILDING 24IAP/AN/AW/SY/AY/AZ244SA/SSTS

(area)

Prepared By S.R. Briggs

Title Project Engineer

Date $03 / 11 / 96$

Type of Project:

$\square$ New Building (or Building Addition)

$\square$ Building Alteration

口Site Development (Grading, Walks, Parking Lots)

四 Other Upgrade of Existing Tank Farm Facilities

Application of Regulations:

DOE Order 6430.1A, "General Design Criteria," General Requirements 0101-4, "Handicapped Provisions."

41 CFR, Public Contracts and Property Management, Subtitle C, 101-19.6, "Accommodations for the Physically Handicapped."

DAll Regulations

$\square$ Limited Application (indicate in comments section)

Exceptions:

DOE Order 6430.1A, "General Design Criteria," General Requirements 0101-4, "Handicapped Provisions."

$[X]$ a. Not intended for occupancy or use by the handicapped

四b. Alteration not involving existing stairs, doors, elevators, toilets, etc.

$\square$ c. Not structurally possible

General Comments:

To support the existing tank farm upgrades. a number of small pre-engineered metal buildings may be installed at the various tank farm facilities. Due. to the remote loctaions of these facilities and the potentially hazardous working conditions. the work requirements and restrictions do not permit handicapped personnel to be assigned to work within the tank farms.

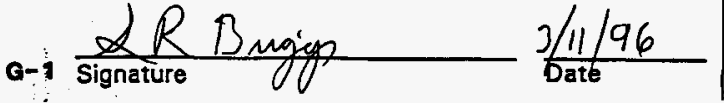




\title{
APPENDIX H
}

\author{
Unreviewed Safety Questions Evaluation
}

(Replaces the Preliminary Safety Evaluation)

(Provided by Operating Contractor) 
WHC-SD-W314-CDR-001, Rev. 0

\section{INITIAL USQ SCREENING EXERCISE FOR PROJECT W-314}

\section{INTRODUCTION}

A Unreviewed Safety Question (USQ) screening exercise was conducted on the proposed tank farm facility upgrades in anticipation of the formal screens, evaluations, and assessments required by the project $W-314$ Systems Safety Program Plan (WHC 1996). Since the CDR is the start of a new project, it is appropriate to start the development of the safety basis at this point. The safety basis for project $W-314$ will be developed via implementation of the USQ process.

The first step in the process is to conduct USQ screening evaluations of each proposed upgrade. The initial screening exercise used the TWRS procedure WHC-IP-0842 (Rev 7). The exercise looked for elements that could be significant cost items during design activities, that would require characterization during conceptual design. None were found.

The screening exercise documented in this report was limited to an evaluation of the upgrades as they will be installed; activities to actually install the items were not considered. Screening of the proposed installation/deployment activities will be performed during Title I and/or Title II design. It is expected that these screenings will identify the need to perform additional USQ evaluations and safety assessments.

The purpose of this report is to document the results of the initial screening exercise, and to provide a degree of confidence that the conceptual design cost estimate has adequately considered potential safety issues. The screening was organized to be consistent with the CDR organization, and with the way the project proposes to conduct the remaining tank farm-upgrades design and construction activities. In some cases, the upgrades were grouped into a single screen. In several cases, it was determined that a USQ evaluation will be needed, and the probable outcome of the evaluations are noted on the screening forms. The tank farm safety basis, i.e., the FSAR, and the USQ process currently are being revised substantialiy. The report aims to provide the foundation for the actual USQ evaluations and screening activities that will take place during the next design phase, taking into account revisions to both the USQ process and the associated safety basis.

\section{METHODOLOGY}

The methodology used to conduct the screening was based on the assumption that the safety related design features of the tank farm facilities (albeit in some cases operating in a marginal physical condition) generally are adequate. Therefore, upgrades which are essentially replacement in kind by definition do not represent USQS. The screens were conducted to determine if the proposed upgrades were either literally replacement in kind or represented improvements in the item's abjlity to perform its safety function. Therefore, for each upgrade category, the proposed new system was compared to the existing system it is intended to replace in terms of the associated safety parameters. For example, piping system safety parameters 
included line size, operating pressure, material of construction, safety classification, method of operation, etc. Ventilation system safety parameters included air flow rates, pressure control, filtration capacity, system reliability, etc.

As the tank farm safety basis definition is further developed and refined, the project $W-314$ safety program will remain cognizant of changes which may affect the project by:

- Tracking the progress of surrogate projects $\mathrm{W}-030$, "Tank Farm Ventilation Upgrade," and W-058, "Replacement of Cross-Site Transfer Pipe Lines."

- Remaining cognizant of the SARs which are being developed to update the current interim safety basis, and the ongoing FSAR revision.

- Reviewing all tank farm USQs and subsequent resolution for precedents which need to be addressed by project $W-314$.

- Revising and augmenting the project W-314 USQ screens, evaluations, and safety assessments as appropriate during subsequent design activities.

\section{SUMMARY OF RESULTS}

\section{Piping}

Al1 proposed piping upgrades were determined to represent changes in form and fit but, in no case, a change in function. The changes in system configuration for piping upgrades involving only pit coatings, valve position indicators, and/or flowmeters were judged to be sufficiently within the bounds of the present facility description, therefore, no changes to these descriptions will be needed. However, the screening process showed that safety assessments may be needed to enable operation of the new valve manifold assemblies proposed for installation in several valve pits throughout the tank farm. Safety assessments may be required as a result of the additional pipelines proposed by the project. The results of the assessments are not expected to cause design changes, but will require changes to operating procedures. The replacement piping systems and new valve manifolds showed a discrepancy in safety classifications.

The relevant interim safety equipment lists (ISEL) indicate that the safety classification for the DST and Aging Waste transfer systems is Class 1 due to the need to protect the environment. However, the environmental hazard safety classification criteria that is the basis for the classification has been deleted from the safety classification procedure, therefore, the USQ screening forms indicate that the present safety classification for the transfer systems is "not classified." The safety classification for the pipelines will be established as part of the ongoing safety basis revision activity. 


\section{Electrical}

In all cases, the electrical system upgrades were determined to represent changes in form or fit, but not in function. The net effect of these upgrades will be to provide more reliable power to the tank farms. The changes in system configuration were judged to be sufficiently within the bounds of the present facility description so changes to these descriptions will not be needed. Therefore, with one exception, no USQ evaluations are planned for the electrical system upgrades.

The CDR safety classification for AY/AZ (Aging Waste Facility) electrical power system is at odds with the pertinent ISEL. The CDR designates the new power system, including cathodic protection, a Safety Class 3 , whereas the ISEL designates the existing power distribution system as Safety Class 2 and the cathodic protection system as Safety Class 1. The ISEL designations would change to either SS or "NC" if the current safety classification criteria were used to update the ISEL (this is expected to happen during the safety basis revision activity noted above). The electrical power distribution systems design distinctions between Safety Class 2 and 3 are moot since both use the same design criteria. The cathodic protection system was designated as Safety Class 1 for the same reason the transfer piping was and should now be classified as "NC."

\section{Ventilation}

Ventilation upgrades proposed by project $W-314$ include replacement of selected annulus and primary ventilation (supply and exhaust) systems. The main differences between the existing systems and those that will be provided by the project are enhanced safety features, changes in system configuration (but not in function or operation), backup capabilities, and improvements in system performance.

The screening of the proposed upgrades determined that because of the enhancements and introduction of new backup capabilities, a change to the facility as described in the Authorization Basis was indicated. The screening process also determined the need to perform some safety assessments because of changes in the operating characteristics of the new systems.

The addition of inlet air controls and new higher capacity fans could result in the need for safety assessments following the USQ evaluations. These assessments are not expected to cause changes to the design as it appears in the CDR, but will require changes in operating procedures and additional discussions of the controls associated with dome loading.

\section{Instrumentation}

AlT proposed changes, with the exception of the master pump shutdown (MPS), to the instrumentation and controls (I\&C) systems were determined to represent changes in form and fit, but not changes in 
function. The proposed changes are modifications and upgrades to the existing I\&C subsystems for the purpose of incorporating current instrumentation technology to replace the antiquated, time-worn, and, in some cases, nonfunctional equipment. For example, the proposed changes include replacing primary tank liquid level gage analog output transmitter cards with digital cards, replacing non-submersible leak detection probes with submersible probes, and replacing existing current/conductivity process pit leak detectors with new resistive/conductivity detectors.

The changes in I\&C system configuration, except for the MPS system, were judged to be sufficiently within the Authorization Basis, therefore, changes to these descriptions will not be needed. With the exception of the MPS, no USQ evaluations are planned for the I\&C systems. Because the modifications to the MPS system involve changes in pump shutdown logic, a USQ evaluation will be required for the new system. 
USQ Tracking No.:

REERRAMTCE DOCOMENT (S) :

ECN No.

Work Pkg No.

TITLE: AN Tank Farm Piping System Upgrades -- Project W-314

Yes/Maybe

Basis: Change consists of providing epoxy colting in pump pits 241-AK-01A, 02A, 03A, 04A, 05A, 06A, 07A, and volve pits $249-A K-A$ and $B$; installing electric valve position indicators in valve pits $241-A M-A$ and $B$, and in pump pits 249-AH-01A through 07A; providing magnetic flow meters on incoming and outgoing lines ot each centrol purp pit; and replacing the existing jumper orrangements in valve pits 261-AN-A and $B$ with valve manifold assembl ies. These changes may require updating the facility and process descriptions in either WHC-SD-WM-SAR-016, or WHC-50-1M-158-009.

B. Does the PROPOSED CHANGE represent a change to procedures as described in the AUTHORIZATION BASIS?

D $N / A$ [) No [xx] Yes/Maybe

Basis: Valve menifolds will replace current procedure of jumper manipulations to affect transfers.

f. Does the test of experiment represent a test or experiment not described in the AUTHORIZATION BASIS documentation?
[xx] N/A
d) No
u Yes/Maybe

Basis: This modification is not considered to be test or experiment.

p. Does the change, test or experiment impact:

- Implemented OSRs or IosRs? I] N/A [xx] No [J Yes/Maybe

- Approved IOSR Compliance Implementation Plans? [O N/A [xx] No [] Yes/Maybe

Basis: DSY IOSRS (UHC-SD-OSR-LM-OSR-016) epplicable to the AN tank farm piping systen upgrade include AC 5.29 Flanmble Gos Control, which pertains to the explosion proof design of valve position indicators and $f(0 w$ meters, AC 5.21 Spare Tankage, which will limit the amount of time transfers from a tank are prohibited due to work in the valve/pump pits, and LCO 3.6.3, COB, Pit and Box Covers, which requires thet these items be covered at all times wile waste transfers are taking place. The proposed upgrade will be fully compliant with these lOSR limitations.

Based on the above, a Safety Evaluation need to be performed for this change*

$[x \times]$ DOES

[] DOES NOT

*It is further concluded that (with the possible exception of the new valve manifolds) the results of the evaluation will probably be negative, based on the fact that only the form and fit of the piping system is being modified, not its function ss a confinement boundary. This is verified by the information in the attoched table. The valve manifolds may require a pafety assessment to demonstrate that the increased nuber of potential leak sites during waste transfers does not pignificantly incresse the risk posed by pipe lesks into the covered pits.

Safety Related Piping Confinement Festures

\begin{tabular}{|c|c|c|}
\hline $\begin{array}{l}\text { Conf inement } \\
\text { Attribute }\end{array}$ & $\begin{array}{l}\text { Existing Design (HHC-SD-LM-SAR- } \\
\text { 016) }\end{array}$ & Proposed Change (UAC-SD-W316-COR-001) \\
\hline Pipe Dianeter & varies & no change \\
\hline $\begin{array}{l}\text { Operoting } \\
\text { Pressure }\end{array}$ & veries & no change \\
\hline Safety Class & ne & Safety significant (equiv. to sc-?) \\
\hline Katerial & carbon steel & stainless steel \\
\hline $\begin{array}{l}\text { Method of } \\
\text { Operation }\end{array}$ & manual, recornect jumpers & valve manifolds, reach rod operated \\
\hline
\end{tabular}


USQ Tracking No.:

REFERENCE DOCUNENT (S) :

ECN No.

Work Pkg No.

IITLE: AH Tank Farm Piping System Upgrades -. Project $\mathrm{H}-314$
Rev. No.:

PCA No.

Other' (Specify) 1. Whe-SD-W316-CDR-009

A. Does the PROPOSED CHANGE represent a change to the facility as described in the AUTHORIZATION BASIS docunentation?

\section{[I $N / A$ [x] No [] Yes/Maybe}

Basis: Change consists of providing epoxy coating in pump pits 261-AL-01A, 02A, 03A, 06A, 05A, 06A, 02E, and valve pits $249-A W-A$ and -B; installing electric valve position indicators in valve pits $241-A H-A$ and $-B$, and in pump pits 241-AW-O1A through OGA and 02E; providing magnetic flow meters on incoming and outgoing lines at each central pumo pit. These changes will not require updating the facility and process descriptions in WHC-SD-MM-SAR-016, or UHC-SD15-158-001.

B. Does the PROPOSED CHANGE represent a change to procedures as described in the AUTHORIZATION BASIS?

\section{[] $\mathrm{N} / \mathrm{A}$ [x] No [] Yes/Maybe}

Basis: The proposed modifications are not expected to require changes to the safety aspects of relevant operating procedures.

C. Does the test or experiment represent a test or experiment not deseribed in the AUTHORIZATION BASIS documentation?

[xx] $N / A$ [] No t] Yes/Maybe

Basis: The proposed modifications are not considered to be tests or experiments.

D. Does the change, test or experiment impact:

- Implemented oSRs or IOSRs? [N N/A [x] No [] Yes/Maybe

- Approved IOSR Compliance Implementation Plans? iJ N/A [xx] No [] Yes/Maybe

Basis: DST JOSRS (WHC-SD-OSR-MM-OSR-016) applicable to the AU tank farm piping system upgrade include AC 5.29 Flamable Gas Control, which pertains to the explosion proof design of valve position indicators and flow meters, and AC 5.21 Spare iankage, which will limit the amount of time transfers from a tank ore prohibited due to work in the valve/pump pits. The proposed upgrade will be fully compliant with these losk limitations.

Based on the above, a Safety Evaluation [] DOES [x] DOES NOT need to be performed for this change*

-Safety Related Piping Conf inement Features

\begin{tabular}{|c|c|c|}
\hline $\begin{array}{l}\text { Conf inement } \\
\text { At tribute }\end{array}$ & $\begin{array}{l}\text { Existing Design (HHC-SD-MM-SAR- } \\
\text { 016) }\end{array}$ & Proposed Change (UHC-SD-WJ14-COR-001) \\
\hline Pipe Dinneter & varies & no change \\
\hline $\begin{array}{l}\text { Operoting } \\
\text { Pressure }\end{array}$ & varies & no change \\
\hline Sofety class & ne & Safety significant (equiv. to sc-2) \\
\hline Material & carbon steel & no change \\
\hline $\begin{array}{l}\text { Method of } \\
\text { operation }\end{array}$ & manual & no change \\
\hline
\end{tabular}


USQ Tracking No.:

REFERTNCE DOCUMATI (s) :

ECN No.

Work Pig No.
Rev. No.:

PCA No.

Other (Specify) 1. UNC-50-1/316-CDR-001

TITLE: AY Tank form Piping System Upgrodes -- Project W-314

A. Does the PROPOSED CHANGE represent a change to the facility as described in the AUTHORIZATION BASIS documentation?

[] N/A D No $D X]$ Yes/Maybe

Basis: Change consists of providing epoxy coating in pump pits 241-AY-01A, and 02A, end sluice pits 241-AY$01 B, C, D, E, 028, C, D, E ;$ installing electric valve position indicators and magnetic flow meters on incoming and outgoing lines at each central pup pit. A new waste transfer line will also be installed to connect pit $02 A$ to pit 020 (the existing waste transfer line SL-504 will be abandoned in place). These changes may require lupdating the facility and process descriptions in SD-HS-SAR-010, Rev 2.

$\bar{B}$. Does the PROPOSED CHANGE represent a change to procedures as described in the AUTHORIZATION BASIS?

[D $N / A$ [x] No I Yes/Maybe

Basis: The proposed modification is not expected to require changes to the safety aspects of relevant operating procedures.

C. Does the test or experiment represent a test or experiment not described in the AUTHORIZATION BASIS documentation?
$[x x] N / A$
[) No
[) Yes/Maybe

Basis: The proposed modification is not considered to be test or experiment.

D. Does the change, test or experiment impact:

- Implemented OSRs or IOSRs? [] N/A [xx] No. [] Yes/Maybe

- Approved IOSR Compliance Implementation Plans? [] N/A [x] No [] Yes/Maybe

Basis: Aging Haste Facility JOSRs (UHC-SD-MH-OSR-004) applicable to the AY tank farm piping system uporade include AC $5.29 \mathrm{Flammable} \mathrm{Gas} \mathrm{Control,} \mathrm{which} \mathrm{pertains} \mathrm{to} \mathrm{the} \mathrm{explosion} \mathrm{proof} \mathrm{design} \mathrm{of} \mathrm{valve} \mathrm{position} \mathrm{indicators} \mathrm{and} \mathrm{flow}$ meters, and AC 5.21 Spare Tankage, which will limit the anount of time transters from a tank are prohibjted due to work in the valve/pump pits. The proposed upgrade will be fully compliant with these IOSR limitations.

Based on the above, a Safety Evaluation [xx] DOES [] DOES NOT need to be performed for this change*

-It is further concluded that the results of the evaluation will probably be negative, besed on the fact that only the form and $f$ it of the piping system is being modified, not its function as a confinement boundary. This is verified by the informstion in the atroched toble.

Sofety Reloted piping Confinement Features

\begin{tabular}{|l|l|l|}
\hline $\begin{array}{l}\text { Confinement } \\
\text { Attribute }\end{array}$ & $\begin{array}{l}\text { Existing Design (UKC-SO-WM-SAR- } \\
016)\end{array}$ & Proposed Chonge (WHC-SD-W314-CDR-001) \\
\hline Pipe Dianeter & veries & no change \\
\hline $\begin{array}{l}\text { Operating } \\
\text { Pressure }\end{array}$ & varies & no change \\
\hline Safety Class & ne & Safety Significant (equiv. to SC-2) \\
\hline Meterial & carbon steel & stainless steel \\
\hline $\begin{array}{l}\text { Method of } \\
\text { Operation }\end{array}$ & manual & no change \\
\hline
\end{tabular}


USQ Tracking No.:

Rev. No. :

REFTRMNCE - DOCONBNT (S) :

ECN No.

PCA No.

Work Pkg No.

Other. (Specify) 1. WHC-SO-W314-CDR-001

TITLE: AZ Tank Farm Piping System Upgrades .- Project W-314

A. Does the PROPOSED CHANGE represent a change to the facility as described in the AUTHORIZATION BASIS documentation?

[] $N / A$ is No $[x x\}$ Yes/Maybe

Basis: Change consists of providing epoxy coating in pump pits 241-A2-01A, and 02A, and stuice pits 241-A2-018,C, $02 B, C_{i}$ installing electric valve position indicstors in sluice pit AZ-D2B and in esch central pump pit, and magnetic flow meters on incoming and outgoing lines at each central pump pit. A valve manifold will be installed in the sluice pit 028 . These changes may require updating the facility and process descriptions in SO-KS-5AR-010, ReV 2, and WHCso-w-1s8-001.

B. Does the PROPOSED CHANGE represent a change to procedures as described in the AUTHORIZATION BASIS?

[] N/A I] No [x] Yes/Maybe

Basis: Liquid waste transfer procedures will need to incorporate operations with the valve manifold.

C. Does the test or experiment represent a test or experiment not described in the AUTHORIZATION BASIS documentation?

[xx] $N / A$ U] No U] Yes/Maybe

Basis: The proposed modification is not considered to be a test or experiment.

D. Does the change, test or experiment impact:

- Implemented OSRs or IOSRs? UN/A $[\times x]$ No [ Yes/Maybe

- Approved IOSR Compliance Implementation Plans? [] N/A [xx] No [? Yes/Maybe

Basis: Aging Waste facility IOSRs (UHC-SD-LW-0SR-006) appliesble to the AZ rank farm piping systen upgrade include AC $5.29 \mathrm{Flamable} \mathrm{Gas} \mathrm{Control,} \mathrm{which} \mathrm{pertains} \mathrm{to} \mathrm{the} \mathrm{explosion} \mathrm{proof} \mathrm{design} \mathrm{of} \mathrm{valve} \mathrm{position} \mathrm{indicators} \mathrm{and} \mathrm{flou}$ meters, AC 5.21 spare Tankage, which will limit the anount of time transfers from a tank are prohibited due to work in the yalve/pump pits, and $1603.6 .3 \mathrm{COB}$, Pit and Box Covers, wich require these items to rema in covered during waste transfer operations. The proposed upgrade will be fully compliant with these losR limitations.

Based on the above, a Safety Evaluation [xx] DOEs I] DOES NOT need to be performed for this change*

- It is further concluded that the results of the evaluation will probably be negative, besed on the fact that only the form and $f i t$ of the piping system is being modified, not its function as a confinement boundary. An exception to this may be a pafety assessmet to verify that the risk of unconfined leaks into the sluice pit resulting from the new manifold is not increased. These conclusions are verified by the information in the attached table.

Safety Related piping confinement features

\begin{tabular}{|c|c|c|}
\hline $\begin{array}{l}\text { Conf inement } \\
\text { At tr ibute }\end{array}$ & $\begin{array}{l}\text { Existing Design (WHC-SD-MH-SAR- } \\
\text { O16) }\end{array}$ & Proposed Change (HHC-SD- U314-CDR-001) \\
\hline Plpe o ianeter & veries & no change \\
\hline $\begin{array}{l}\text { Operating } \\
\text { Pressure }\end{array}$ & veries & no change \\
\hline Sofety Cliss & $n e$ & Sofety significant (equir. to sc-2) \\
\hline Material & earbon steel & stuinless steel \\
\hline $\begin{array}{l}\text { Method of } \\
\text { Operation }\end{array}$ & manual & no change \\
\hline
\end{tabular}


USQ Tracking No.:

Rev. No.:

REFERMNCE DOCOMNAT (s) :

ECN No.

PCA NO.

Work Pkg No.

Other. (Specify) 1. WHC-S0-W314-COR-001

TITLE: AP Tank Farm Piping Systen Upgrades .. Project W-314

A. Does the PROPOSED CHANGE represent a change to the facility as described in the AUTHORIZATION BASIS documentation?

[] N/A [xx] No [] Yes/Maybe

Bas1s: Change consiste of providing epoxy coating in pump pits 261-AP-01A, 02A, 03A, 04A, 05A, 06A, 07A, 08A, 020, and valve pit 249-AP; installing electric valve position indicators in valve pit 241-AP, and in pump pits 241-AP-084 and 020; providing magnetic flow meters on inconing and outgoing lines at each central pump pit. These changes will not require updating the facility and process descriptions in UHC-SD-WM-SAR-016, WHC-SD-WH-ISB-001.

B. Does the PROPOSED CHANGE represent a change to procedures as described in the AUTHORIZATION BASIS?

[] $N / A$ [xx] No [] Yes/Maybe

Basis: The proposed modification is not expected to require changes to the safety aspects of relevant operating procedures.

C. Does the test of experiment represent a test or experiment not described in the AUTHORIZATION BASIS documentation?

[xx] N/A I] No U Yes/Maybe

Basis: This change is not considered to be test or experiment.

D. Does the change, test or experiment impact:

- Implemented OSRs or IOSRs? II N/A [xx] No I] Yes/Maybe

- Approved IOSR Compliance Implementation Plans? [] N/A [xx] No [] Yes/Maybe

Basis: DST 105Rs (WHC-50-05R-LM-0SR-016) applícable to the AP tank farm piping systen upgrade include $A C 5.29$ Flanmable cas control, which pertains to the explosion proof design of valve position indicators and flow meters, and AC 5.21 spare Tankage, wich will limit the emount of time transfers from a tank are prohibited due to work in the valve/pump pits. The proposed upgrode will be fully compliant with these losR limitations.

Based on the above, a Safety Evaluation [D DOES [xx] DOEs NOT need to be performed for this change*

*Safety Related Piping Confinement features

\begin{tabular}{|l|l|l|}
\hline $\begin{array}{l}\text { Confinement } \\
\text { Attribute }\end{array}$ & $\begin{array}{l}\text { Existing Design (WHC-SD-WM-SAR- } \\
016)\end{array}$ & Proposed Change (WMC-50-W314-CDR-001) \\
\hline Pipe Diameter & varies & no change \\
\hline $\begin{array}{l}\text { Operating } \\
\text { Pressure }\end{array}$ & varies & no change \\
\hline Safety Class & ne & Sofety Significant (equiv. to SC-2) \\
\hline Material & carbon steel & no change \\
\hline $\begin{array}{l}\text { Method of } \\
\text { Operation }\end{array}$ & manual & no change \\
\hline
\end{tabular}


USQ Tracking No.:

Rev. No.:

RETEREACE DOCORTAT (S) :

ECN No.

Work Pkg No.
PCA No.

Other (Specify) 1. WHC-SD-W314-COR-001

IIILE: 2E/2W Area Tank Farm Piping System Upgrades -- Project W-314

A. Does the PROPOSED CHANGE represent a change to the facility as described in the AUTHORIZATION BASIS documentation?

D $N / A$ [] No :[xx] Yes/Maybe

Basis: Change consists of providing epoxy coating in and electric valve position indicators for valve pits 241-A-A and $B, A X-A$ and $B$; and replacing the existing jumper arrangements in these four valve pits with valve manifold assegblies. Three mew underground transfer lines will also be provided, including lines connecting the 241-AN-B velve pit to the $241-A Z-02 b$ sluice pit, the $241-A Z-02 B$ sluice pit to the $241-A X-A$ valve pit, ond the $241-A-A$ valve pit to the $241-A L-A$ valve pit. Three transfer lines will also be repleced, including line sk-216 from the 241-A-B valve pit to the 244-A DCRT, line SK-213/200 from the 241-A-B valve pit to the $241-A X-B$ valve pit, and the line $5 L$. 502 from the $249-\lambda \times-8$ valve pit to the $241-A Y-020$ pit. These changes will require updating the facility and process descriptions in WHC-SD-WM-SAR-016, and WHC-SD-WM-1SB-001.

B. Does the PROPOSED CHANGE represent a change to procedures as described in the AUTHORIZATION BASIS?

[] $N / A$ [] No $[x x]$ Yes/Maybe

Basis: Additional ovailable waste transfer routes.

C. Does the test or experiment represent a test or experiment not described in the AUTHORIZATION BASIS documentation?

[xw] $N / R$ i) No [J Yes/Maybe

Basis: The proposed modificotion is not considered to be a test or experiment.

D. Does the change, test or experiment impact:

- Implemented OSRs or IOSRs? [I N/A [xx] No [] Yes/Maybe

- Approved IOSR Compliance Implementation Plans? [] N/A [xx] No [] Yes/Maybe

Basis: The OST IOSRs (HHC-SO-OSR-WM-OSR-096) applicable to the 2E/ZW Area tank farm piping system upgrade are AC 5.21 'Spare Tankage", which will limit the anount of time transfers from tank are prohibited due to work in the valve/pump pits, and LCO 3.6.3 COB, Pit and Box Covers, which require that these irems remain covered at oll times during waste transfers. The proposed upgrade will be fully compliant with these jOSR linitations.

Based on the above, a Safety Evaluation [xx] DOEs [J DOES NOT need to be performed for this change*

"It is further concluded that (with the possible exception of the new volve manifolds and pipe (ines) the results of the evaluation will probably be negative, based on the foct that only the form and fit of the piping system is being modified, hot its function as confinement boundary. This is verified by the information in the attached table. The valve manifolds may require safety assessment to demonstrate that the increased number of potential leak sites during waste transfers does fiot significantly increase the risk posed by pipe leaks into the covered pits. A Safety Assessment may also be required to bemonstrate that the increased risk of waste transfer system leaks outside the pits resulting from the odditional lines is hot ignificant. 


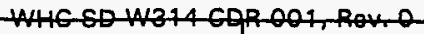

UNREVIEWED SAFETY QUESTION SCREENING FORM (Continued)

Page 2 of 2

\begin{tabular}{|c|c|c|}
\hline $\begin{array}{l}\text { Conf inement } \\
\text { Attribute }\end{array}$ & $\begin{array}{l}\text { Existing Design (WHC-SD-WM-SAR- } \\
016 \text { ) }\end{array}$ & Proposed Change (WHC-SD-W314-COR-001) \\
\hline Pipe Disneter & varies & no change \\
\hline $\begin{array}{l}\text { Opersting } \\
\text { Pressure }\end{array}$ & varies & no change \\
\hline safety Class & ne & Sofety significant (equiv. to sc-2) \\
\hline Material & cerbon steel & stainless steel \\
\hline $\begin{array}{l}\text { Method of } \\
\text { Operation }\end{array}$ & manusl, recomect jumpers & valve menifolds, resch rad operated \\
\hline
\end{tabular}


USQ Tracking No.:

REFERATCE DOCOMANT (s) :

ECN No.

Work $\mathrm{Pkg}$ No.

TITLE: SY Tank Farm Piping System Upgrodes $\cdots$ Project $\mathbf{H}-314$
Rev. No.:

PCA No.

Other. (Specify) 1. WHC-SO- $1314-C D R-001$

A. Does the PROPOSED CHANGE represent a change to the facility as described in the AUTHORIZATION BASIS documentation?

I] $N / A$ [xx] No [] Yes/Maybe

Basis: Change consists of providing epoxy coating in pamp pits 241-5Y-01A, 02A, 03A, 02E, and valve pits 241-5Y-A and $B$; installing electric valve position indicators in valve pits 241-AP, and in the central pump pits; and providing magnetic flow meters on incoming ond outgoing lines at each central pump pit. These ehanges will not require updating the facility and process deseriptions in WHC-SD-WH-SAR-016, or WHC-SD-LA-ISB-001.

B. Does the PROPOSED CHANGE represent a change to procedures as described in the AUTHORIZATION EASIS?

[] $N / A$ [xx] No [] Yes/Maybe

Basis: Operating procedures, at the safety controls level, ore not expected to change.

C. Does the test or experiment represent a test or experiment not described in the AUTHORIZATION BASIS documentation?

[xu N/A I No IJ Yes/Maybe

Basis: The proposed modification is not considered to be test or experiment.

D. Does the change, test or experiment impact:

- Implemented OSRs or IOSRs? [] N/A [xx] No [I Yes/Maybe

- Approved IOSR Compliance Implemertation Plans? U N/A [xx] No [U Yes/Maybe

Basis: DST JOSRs (WHC-SD-OSR-LM-OSR-016) epplicable to the SY tank farm piping system uparade include AC 5.29 Flamable Gas control, which pertains to the explosion proof design of valve position indicators and flow meters, and AC 5.21 Spare Tankage, which will limit the amount of time transfers tram a tank are prohibited due to work in the valve/punp pits. The proposed uprade will be fully compliant with these lOSR limitatians.

Based on the above, a Safety Evaluation [] DOES [xx] DOES NOT need to be performed for this change*

Safety Related Piping Confinement Features

\begin{tabular}{|l|l|l|}
\hline $\begin{array}{l}\text { Confinement } \\
\text { Attribute }\end{array}$ & $\begin{array}{l}\text { Existing Design (WHC-SD-WM-SAR- } \\
016)\end{array}$ & Proposed Change (WHC-SD-LS14-CDR-001) \\
\hline Pipe Diemeter & varies & no change \\
\hline $\begin{array}{l}\text { Operating } \\
\text { Pressure }\end{array}$ & varies & no change \\
\hline $\begin{array}{l}\text { Safety Class } \\
\text { Moterial }\end{array}$ & ne & Safety Significant (equiv. to SC-2) \\
\hline $\begin{array}{l}\text { Method of } \\
\text { Dperation }\end{array}$ & manual & no change \\
\hline
\end{tabular}


USQ Tracking No.:

\section{REFERENCE DOCUMENT(S):}

ECN No.

Work Pkg No.
Rev. No.:

PCANo.

Other (Specify) Project W.314 CDR-001

TITLE: SY Annulus Ventiation System Upgrade (Supply)

A. Does the PROPOSED CHANGE represent a change to the facility as described in the AUTHORIZATION BASIS documentation?

ON/A QNo $[\mathrm{X}]$ Yes/Maybe

Basis: The change consists of rodundant air intake stations for cach individual tank replacing the existing stiernate annulus supply filter units. These chenges will incorporate electric heaters, prefilters, HEPA fitters, and isolation valves.

B. Does the PROPOSED CHANGE represent a change to procedures as described in the AUTHORIZATION BASIS? [N/A DNo $[X]$ Yes/Maybe

Basis: The upgraded changes consists of completely new systerns which will necessitate procedural changes if not new procedures.

C. Does the test or experiment represent a test or experiment not described in the AUTHORIZATION BASIS documentation? [X] N/A DNo D Yes/Maybe

Basis: The upgrades are not considered a test or experiment.

D. Does the change, test or experiment impact:

- Implemented OSRs or IOSRs? [N/A [X]No Q Y Yes/Maybe

- Approved IOSR Compliance Implementation Plans? [N/A [X] No D Yes/Maybe

Basis: There are no IOSRs applicable to DST Annulus Ventilation Systems.

Based on the above, a Safety Evaluation [ $X$ ] DOES DDOES NOT need to be performed for this change 
USQ Tracking No.:

\section{REFERENCE DOCUMENT(S):}

ECN No.

Work Pkg No.
Rev. No:

PCANo.

Other (Specify) Project W-314 CDR-001

TITLE: 244-A DCRT Ventilation System Upgrade (Supply)

A. Does the PROPOSED CHANGE represent a change to the facility as described in the AUTHORIZATION BASIS documentation?

ON/A DNo [X] Yes/Maybe

Basis: The change consists of providing an above grade outside air supply to the Annulus. The supply system includes an intake plenum, eiectric heater, prefilter, DOP testable HEPA filter, and isolation valves. This equipment will be connected to the existing 6-in. inlet pipe.

$-$

B. Does the PROPOSED CHANGE represent a change to procedures as described in the AUTHORIZATION BASIS?

DN/A QNo [X] Yes/Maybe

Basis: New system/new procedures.

C. Does the test or experiment represent a test or experiment not described in the AUIHORIZATION BASIS documentation? [X]N/A DNo OYes/Maybe

Basis: The upgrades are not considered a test or experiment.

D. Does the change, test or experiment impact:

- Implemented OSRs or IOSRs? QN/A $X X$ No D Yes/Maybe

- Approved IOSR Compliance Implementation Plans? [N/A [X] No O Yes/Maybe

Basis: See DST IOSRs.

Based on the above, a Safety Evaluation [X] DOES $\square$ DOES NOT

need to be performed for this change 
USQ Tracking No::

Rev. No.:

\section{REFERENCE DOCUMENT(\$):}

ECN No.

PCA No.

Work Pkg No.

Other (Specify) WHC-SD-W314-001, Rev. 0

TITLE: ELECTRICAL UPGRADES FOR THE SST FARMS

A. Does the PROPOSED CHANGE represent a change to the facility as described in the AUTHORIZATION BASIS documentation?

D N/A [X] No D Yes/Maybe

Basis: A new 75 kVA transformer will be installed to feed a new service distribution panel board CCS. The CSS board will feed $480 \mathrm{~V}, 3 \phi$ to existing loads and a new mini-power center to supply $120 / 240 \mathrm{~V}$ to miscellaneous instruments. Only facility deseription changes in WHC-SD-WMISB-001, Rev. 0 will be required.

B. Does the PROPOSED CHANGE represent a change to procedures as described in the AUTHORIZATION BASIS?

[N/A [X] No QYes/Maybe

Basis: The proposed upgrades will require no change to the authorization basis.

C. Does the test or experiment represent a test or experiment not described in the AUTHORIZATION BASIS documentation? [X]N/A DNo DYes/Maybe

Basis: There are no tests or experiments involved with the electrical upgrades.

D. Does the change, test or experiment impact:

- Implemented OSRs or IOSRs? DN/A [X] No OYes/Maybe

- Approved IOSR Compliance Implementation Plans? ON/A [X] No [ YesMaybe Basis:

Based on the above, a Safety Evaluation 0 DOES [X] DOES NOT need to be performed for this change 
USQ Tracking No.:

REFERENCE DOCUMENT(S):

ECNNo.

Work Pkg No.

TITLE: SY Annulus Ventilation System Upgrade (Exhaust)

A. Does the PROPOSED CHANGE represent a change to the facility as described in the AUTHORIZATION BASIS documentation?

[N/A DNo [X] Yes/Maybe

Basis: The change consists of a new exhaust system divided into two units of isolation valves, contol valves, prefilters, HEPA fitters, test stations, and fans. A new slack and monitoring system will also be added.

B. Does the PROPOSED CHANGE represent a change to procedures as described in the AUTHORIZATION BASIS?

QN/A DNo $[\mathrm{X}]$ Yes/Maybe

Basis: Procedure changes will be primarily affected by the introduction of backup capabilities.

C. Does the test or experiment represent a test or experiment not described in the AUTHORIZATION BASIS documentation? [X]N/A DNo D Yes/Maybe

Basis: The upgrades are not considered a test or experiment.

D. Does the change, test or experiment impact:

- Implemented OSRs or IOSRs? [N/A [X]No OYes/Maybe

- Approved IOSR Compliance Implementation Plans? QN/A DX No QYes/Maybe

Basis: There are no IOSRs applicabie to DST Annulus Ventilation Systems.

Based on the above, a Safety Evaluation $[X]$ DOES [DOES NOT

need to be performed for this change 


\section{UNREVIEWED SAFETY QUESTION SCREENING FORM}

(Per WHC-IP-0842)

Page 1 of 1

USO Tracking No.:

Rev. No.:

REFERENCE DOCUMENT(S):

ECN No.

PCA No.

Work Pkg No.

Other (Specify) Project W-314 CDR-001

TITLE: 244-A DCRT Ventilation System Upgrade (Exhaust)

A. Does the PROPOSED CHANGE represent a change to the facility as described in the AUTHORIZATION BASIS documentation?

I] N/A [] No [X] Yes/Maybe

- Basis: The change consists of providing an above grade dual exhaust system. The exhaust system includes motorized isolation valves, electric heaters, DOP testable HEPA filters, housing for future carbon adsorbers, variable speed exhaust fans, and a stack. the dual exhaust trains will be be protected by concrete shield walls and a removable roof.

B. Does the PROPOSED CHANGE represent a change to procedures as described in the AUTHORIZATION BASIS?

I] N/A [] No [X] Yes/Maybe

Basis: New system/new procedure.

C. Does the test or experiment represent a test or experiment not described in the AUTHORIZATION BASIS documentation?

[X] N/A [] No I] Yes/Maybe

Basis: The upgrades are not considered a test or experiment.

D. Does the change, test or experiment impact:

- Implemented OSRs or IOSRs? [] N/A [X] No I] Yes/Maybe

- Approved IOSR Compliance Implementation Plans? [I N/A [X] No II Yes/Maybe

Basis: See DST IOSRs.

Based on the above, a Safety Evaluation [X] DOES if DOES NOT need to be performed for this change 


\section{UNREVIEWED SAFETY QUESTION SCREENING FORM}

(Per WHC-IP-0842)

Page 1 of 1

USQ Tracking No.:

Rev. No:

REFERENCE DOCUMENT(S):

ECN No.

PCA No.

Work Pkg No.

Other (Spocify) WHC-SD-W314-CDR-001, Rev. 0

TITLE: AN-, AP-, AW-, AY-, AZ-, SY-, 244-A-DCRT, \& 244-S-DCRT Tank Farm Mester Pump Shutdown (MPS) I\&C UPgrades

A. Does the PROPOSED CHANGE represent a change to the facility as described in the AUTHORIZATION BASIS documentation?

[N/A DNo [X] Yes/Maybe

Basis:The proposed thanges are capital improvements to the existing tank farm master pump shutdown system instrument and control system necessary to the support safe storage and eflicient transfer of tank wastes. The proposed upgrades are intended to improve the efficiency of waste transfe operations by elimineting unwarrented pump shutdowns. As presently configured, the MPS will siop all pumps operating in the entire tank farm, as well as those feoding the tenk farm, if a leak detector is activiated anywhere in the transfer system even if the active detector is not in the system then currently in use. Pumping operations can not be resumed until the leak, if real, is repaired or, if not real, the sporious signal is cleared. The proposed upgrade will modify the logic so that a pump will be shutdown only if a leak detector is activated in the transfer system(s) diroctly involved in the pumping opereation. A conversation with the cognizant I\&C engineer indiented the design of the proposed upgrade has not been finatized. Until the design of the MPS is more clearly defined, it was deemed prudent to assume the proposed changes will represent changes to the facility as described in the authorization basis document.

B. Does the PROPOSED CHANGE represent a change to procedures as described in the AUTHORIZATION BASIS?

$\square$ N/A [X]No Q Yes/Maybe

Basis: The functional aspects of the system as it is described in the operating procedures is not expected to change.

C. Does the test or experiment represent a test or experiment not described in the AUTHORIZATION BASIS documentation? $[X]$ N/A $\square$ No 0 Yes/Maybe

Basis: These changes do not represent tests or experiments.

D. Does the change, test or experiment impact:

- Implemented OSRs or IOSRs? DN/A [X] No D Yes/Maybe

- Approved IOSR Compliance Implementation Plans? ON/A [X] No DYes/Maybe

Basis: The purpose of these upgrades is to ensure full compliance with existing IOSRs.

Based on the above, a Safety Evaluation [X]DOES [DOES NOT need to be performed for this change 
UNREVIEWED SAFETY QUESTION SCREENING FORM

(Per WHC-IP-0842)

Page 1 of 1

USQ Tracking No.:

\section{REFERENCE DOCUMENT(S):}

ECN No.

Work Pkg No.
Rev. No:

PCA No.

Other (Specify) WHC-SD-W314-CDR-001, Rev. 0

TITLE: AN-, AP-, AW-, AY-, AZ-, SY, 244-A-DCRT, \& 244-S-Tank Farms Primary Tank I\&C Upgrades

A. Does the PROPOSED CHANGE represent a change to the facility as described in the AUTHORIZATION BASIS documentation?

[N/A [X]No D Yes/Maybe

Basis: The proposed changes are cepital improvements to the existing primary tank instrumentation and control system necessary to support continued safe storge of tank westes. The proposed changes, consisting of modifieations and upgrades to existing systems, are for the purpose of incorporating modern measurement equipment to replace antiquated, time-wom equipment now in service. Significant changes include replacing the liquid level gages analog output transmitter cards with a digital transmitter card; the current/conductivity liquid level high alarm probe will be replaced with a resistive/ conductivity liquid presence detector, the high and low range vapor space pressure pneumatic transmitters will be replaced by electronic pressure transmitters.

B. Does the PROPOSED CHANGE represent a change to procedires as described in the AUTHORIZATION BASIS?

QN/A $[X]$ No $D$ Yes/Maybe

Basis: The functional aspects of the system as it is described in the operating procedures is not expected to change.

C. Does the test or experiment represent a test or experiment not described in the AUTHORIZATION BASIS documentation? $[X]$ N/A DNo D Yes/Maybe

Basis: These changes do not represent tests or experinents.

D. Does the change, test or experiment impact:

- Implemented OSRs or IOSRs? DN/A [X] No Q Yes/Maybe

- Approved IOSR Compliance Implementation Plans? ON/A [X]No O Yes/Maybe

Basis: The purpose of these upgrades is to ensure full compliance with existing 10 SRs.

Based on the above, a Safety Evaluation [DDES [X] DOES NOT need to be performed for this change 


\section{UNREVIEWED SAFETY QUESTION SCREENING FORM}

(Per WHC-IP-0842)

Page 1 of 1

USQ Tracking No:

Rev. No.:

\section{REFERENCE DOCUMENT(S):}

ECN No.

PCANo.

Work Pkg No.

Other (Specify) WHC-SD-W314-CDR-001, Rev. 0

TITLE: AN-, AP-, AW-, AY-, AZ-, SY-, 244-A-DCRT, \& 244-S-DCRT Tank Farm Waste Transfer System I\&C Upgrades

A. Does the PROPOSED CHANGE represent a change to the facility as described in the AUTHORIZATION BASIS documentation?

DN/A $[\mathrm{X}]$ No DYes/Maybe

Basis: The proposed changes are capital inprovements to the existing waste transfer instrumentation and control system nocessary to support continued safe storage of tank westes. The proposed changes are modifications and upgrades to existing waste transfer system instrumentation. The upgades will inoorporate current instrumentation technology in place of antiquated, time-worn equipment now in place. The proposed upgrades to the waste transfer system instrumentation is as follows. Valve positioning indicators will be added to the new and existing valves in the waste transfer system for the AN-, AP-, AW-, AY-, AZ(sluee pit AZ-02B and central pump pits), and SY(244-SY-A, \& -B pits and central pump pits)-Tank Farms. Mngnetic flow meters will be installed on each inlet and outlet transfer line for the AN-, AP-, AW-, AY-, AZ-, and SY-Tank Farms. Raw water flow measurements will be provided by a turbine flowmeter installed in the service pit for AN-, AP-, AW-, AZ-, SY(241-SY-A flush pit)-, 244-A-DCRT, and 244-S-DCRT Tank Fams, A bquid effluent radiation monitor will be installed in the service pit and an associated rate count meter will be installed in the annulus enclosure assembly for 244-A-DCRT and 244-S-DCRT Tank Farms.

B. Does the PROPOSED CHANGE represent a change to procedures as described in the AUTHORIZATION BASIS?

[N/A $[\mathrm{X}]$ No $\mathrm{Q}$ Yes/Maybe

Basis: The functional aspects of the system as it is described in the operating procedures is not expected to change.

C. Does the test or experiment represent a test or experiment not described in the AUTHORIZATION BASIS documentation? [X] N/A $\square$ No $\square$ Yes/Maybe

Basis: These changes do not represent tests of experiments.

D. Does the change, test or experiment impact:

- Implemented OSRs or IOSRs? DN/A. [X] No O Yes/Maybe

- Approved IOSR Compliance Implementation Plans? DN/A [X] No a Yes/Maybe

Basis: The purpose of these upgrades is to ensure full compliance with existing IOSRs.

Based on the above, a Safety Evaluation 0 DOES [X] DOES NOT need to be performed for this change 


\section{UNREVIEWED SAFETY QUESTION SCREENING FORM}

(Per WHC-IP-0842)

USQ Tracking No:

Rev. No.:

\section{REFERENCE DOCUMENT(S):}

ECN No.

PCA No.

Work Pkg No.

Other (Specify) WHC-SD-W314-CDR-001, Rev. 0

TITLE: AN-, AP-, AW-, SY-, 244-A-DCRT, \& 244-S-DCRT Tank Ferm Primary Exhaust Ventilation System I\&C Upgrades

A. Does the PROPOSED CHANGE represent a change to the facility as described in the AUTHORIZATION BASIS documentation?

DN/A $[\mathrm{X}]$ No $\mathrm{O}$ Yes/Maybe

Basis: The proposed changes are capital improvements to the existing primary exhaust ventilation instrumentation and control system necessary to support continued sare storage of tank wasles. The proposed changes are modifications and upgrades to existing primary exhaust ventilation system instrumentation. The upgrades will incorporate current instrumentation technology in place of antiquated, time-worn equipment now in place. Ihe proposed upgrades for the AN-, AP-, and the AW-Tank Farms are as follows: the exhaust train inlet manifold pressure will be measured with respect to atmosphere; the demister, HEPA Giters, and exhaust fan differential pressures will be measured; train inlet, hester outlet, and train outlet temperatures will be measured; a heater controller will be installed next to the exhaust train heater, exhaust train valve motors will be uired to a switehed signal from the loeal IFLAN I/O box through an interposing relay, the damper motor controller will be wired to an analog control signal from the IFLAN VO box; provisions will be made to measure the condensate drain pit seal liquid level; and a exhaust stack radiation monitoring system will be installed in the tank farm primary ventilation stack The proposed SY-Tank Farm upgrades are as follows: the exhaust train inlet manifold pressure instrumentation and the primary ventilation stack monitoring system upgrades will be similar to those proposed for the AN-, AP-, and AW-tank Farms, signals from the demister, prefilter, HEPA filters system pressure analog signals, duet heater differential ternperature indicating transmitter, and the seal pot high and low liquid level monitor will be input to a local IFLAN I/O box. Upgrades for thee 244-A-DCRT and the 244-S. DCRT Tank Farms will be similar to those proposed for the SY-Tank Farm except that no demister differential pressure and inlet pressure instruments will be provided and no stack monitor will be installed by this project (W-314).

B. Does the PROPOSED CHANGE represent a change to procedures as described in the AUTHORIZATION BASIS?

DN/A [X] No D Yes/Maybe

Basis: The functional espects of the system as it is described in the operating procedures is not expected to change.

C. Does the test or experiment represent a test or experiment not deseribed in the AUTHORIZATION BASIS documentation? [X] N/A DNo D Yes/Maybe

Basis: These changes do not represent tests or experiments.

D. Does the change, test or experiment impact:

- Implemented OSRs or IOSRs? DN/A [X]No „IYes/Maybe

- Approved IOSR Compliance Implementation Plans? ON/A [X] No D Yes/Maybe

Basis: The purpose of these upgrades is to ensure full compliance with existing IOSRs.

Based on the above, a Safety Evaluation DDOES [X]DOES NOT need to be performed for this change 
USQ Tracking No:

Rev. No.:

REFERENCE DOCUMENT(S):

ECN No.

PCANo.

Work Pkg No.

Other (Specify) WHC-SD-W314-CDR-001, Rev. 0

TIILE: AN-, AP-, AW-, AY-, AZ-, SY, 244-A-DCRT, \& 244-S-DCRT-Tank Farms Leak Detection I\&C Upgrades

A. Does the PROPOSED CHANGE represent a change to the facility as described in the AUTHORIZATION BASIS documentation?

DN/A [X]No QYes/Maybe

Basis: The proposed changes are capital improvements to the existing tank farms leak detection instrumentation and control system necessary to

- support safe storage of tank wastes. The proposed chenges, consisting of modifications and upgrades to existing systems, are for the purpose of incorporating modern leak detection equipment to replace antiquated, time-korn equipment now in service. Changes of interest include replacing the resistive/conductivity tank annulus liquid presence detectors, replacing the existing tank annulus CAM leak detectors with updated instruments of the same type; replacing the existing leak detection pit non-submersible gamma probes with submersible units, installing a resistive/conductivity liquid leak detoctor in each dry pit, replacing existing current/conductivity process pit leak detoctors with new resistive/conductivity detectors; and installing new resistive/conduetivity leak detectors in transfer line encasement pipes and clean out boxes.

B. Does the PROPOSED CHANGE represent a change to procedures as described in the AUTHORIZATION BASIS?

DN/A [X]No Q Yes/Maybe

Basis: The functional aspects of the system as it is described in the operating procedures is not expected to change.

C. Does the test or experiment represent a test or experiment not described in the AUTHORIZATION BASIS documentation? [X] N/A DNo Q Yes/Maybe

Basis: These changes do not represent tests or experiments.

D. Does the change, test or experiment impact:

- Implemented OSRs or IOSRs? DN/A [X]No DYes/Maybe

- Approved IOSR Compliance Implementation Plans? ]N/A $[x]$ No D Yes/Maybe

Basis: The purpose of these upgrades is to ensure full compliance with existing lOSRs.

Based on the above, a Safety Evaluation [0DOES [X] DOES NOT

need to be performed for this change 


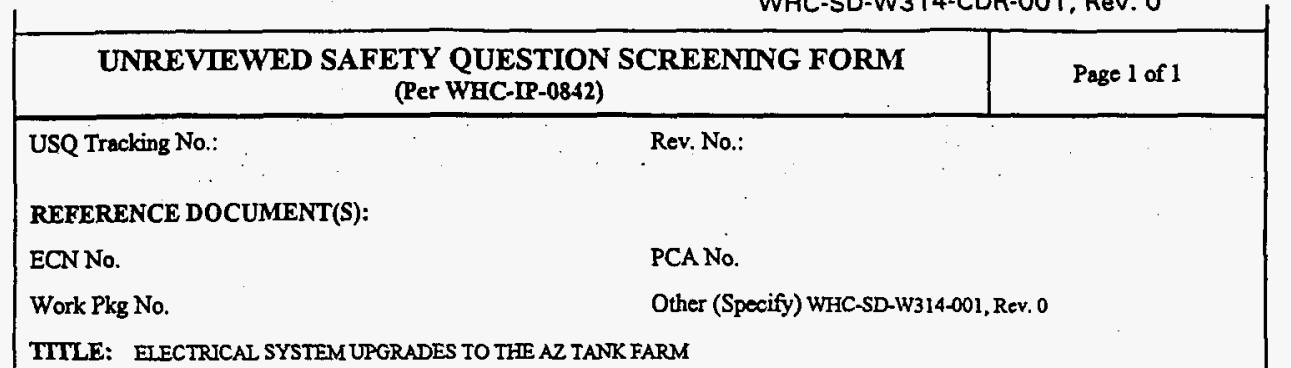

A. Does the PROPOSED CHANGE represent a change to the facility as described in the AUTHORIZATION BASIS documentation?

QN/A [X] No Q Yes/Maybe

Basis: A new motor control center will replace the existing MCC-2. This MCC will feed a new mini-control center provided to supply $120 \mathrm{v}$ to

- instrumentation equipment and control panel. Existing annulus ventilation panel and heater coritrollers will be replaced with new components. Existing cathodic protoction will be modified to protect new underground process piping.

B. Does the PROPOSED CHANGE represent a change to procedures as described in the AUTHORIZATION BASIS?

DN/A [X] No 0 Yes/Maybe

Basis: The authorization basis will not be affected by the eiectrical upgrades.

C. Does the test or experiment represent a test or experiment not described in the AUTHORIZATION BASIS documentation? $[\mathrm{X}]$ N/A DNo $\mathrm{Y}$ Yes/Maybe

Basis: No tests or experiments are involved with the upgrades.

D. Does the change, test or experiment impact:

- Implemented OSRs or IOSRs? DN/A [X] No Q Yes/Maybe

- Approved IOSR Compliance Implementation Plans? DN/A [X] No DYes/Maybe

Basis:

Based on the above, a Safety Evaluation [DOES [X]DOES NOT need to be performed for this change 
WHC-SD-W314-CDR-001, Rev. 0

UNREVIEWED SAFETY QUESTION SCREENING FORM

(Per WHC-IP-0842)

USQ Tracking No:

Rev. No.:

\section{REFERENCE DOCUMENT(S):}

ECN No.

PCA No.

Work Pkg No.

Other (Specify) wHC-SD-W314-CDR-001, Rev. 0

\section{TITLE: ELECTRICAL UPGRADES TO THE AY TANK FARM}

A. Does the PROPOSED CHANGE represent a change to the facility as described in the AUTHORIZATION BASIS documentation?

[N/A $[\mathrm{X}]$ No $\mathrm{Z}$ Yes/Maybe

Basis: A new motor control center MCC-AYl will replace the existing MCC. Trip setting on the feeder bresker for the new MCC will be changed from 650 a to 350 s to provide overcurrent protection. A new mini-power center to provide $120 \mathrm{v}$ to the new instrumentation equipment and control pand will be instalied. The new MCC will feed this power center. The existing HVAC control panels for tanks AY-101 and AY-102, along with existing heater controllers will be replaced. Only facility description changes to WHC-SD-WM-ISB-001 will be necessary.

B. Does the PROPOSED CHANGE represent a change to procedures as described in the AUTHORIZATION BASIS?

[N/A $[X]$ No OYes/Maybe

Basis: The upgrades do not involve any changes in the authorization basis.

C. Does the test or experiment represent a test or experiment not described in the AUTHORIZATION BASIS documentation? [X] N/A DNo QYes/Maybe

Basis: There are no tests or experiments involved with the upgrades.

D. Does the change, test or experiment impact:

- Implemented OSRs or IOSRs? DN/A [X] No Q Yes/Maybe

- Approved IOSR Compliance Implementation Plans? [N/A [X] No 0 Yes/Mrybe

Basis:

Based on the above, a Safety Evaluation 0 DOES [X] DOES NOT

need to be performed for this change 
USQ Tracking No.:

Rev. No:

REFERENCE DOCUMENT(S):

ECN No.

PCANo.

Work Pkg No.

Other (Specify)

WHC-SD-W314-CDR-D01, Rev. 0

TITLE: Electrical Upgrades for the AN, AP, AW, and SY Tank Farms

A. Does the PROPOSED CHANGE represent a change to the facility as described in the AUTHORIZATION BASIS documentation?

[N/A [X] No QYes/Maybe

Basis: Electrical upgrades for the AN Tank Farm consist of installation of two 100 circuit breaker for the ventiation system. A new receptacle and manual transfer switch for connection of a diesel generator for backup power for maintenance purposes to primary ventilation electrical equipment. Also, addition of two combination stariers and a power panel. A new cathodic protection system will be installed. All changes are replacement to existing systems and will probably represent no change in the safety basis. Changes involve only enhancements to cxisting systems and involve no procedural changes in WHC-SD-WM-SAR-016. There will necessarily be facility descriptive changes in WHC-SD-WM-ISB-001.

Due to the sinilarity of AP tank farm to AN tunk farm the electrical changes to AP tank farm are the same as those for the AN tank farm with the followirg exceptions: a main 100a circuit breaker for the existing $1000 \mathrm{kVA}$ transformer will not be provided; the replacement 120 receptacle for diesel generator connection will be fence mounted and be of GFCI configuration; the toceptacle will be fed from a new 20a circuit breaker in panelboard EDS-DP-304 located inside 241-AP-801. Changes involve only enhancements to existing systems and involve no procedural changes in WHC-SD-WM-SAR-016. There will necessarily be facility deseriptive changes in WHC-SD-WM-ISB-001.

Electrical upgrades to the AW Tank Farm are the same as described for the AN tank farms with the following differences: A 100 circuit breaker. wire gutter, $3 \mathrm{kVA}$ power center with four GFCI receptacles will be installed on the existing diesel generator. A $150 \mathrm{ft}$, 100s power cord will installed at the genentor on a joel for hookup to the sew primary ventilation backup power system. Changes involve only enhancements to existing systems and involve no procodural changes in WHC-SD-WM-SAR-016. There will nocessarily be facility descriptive changes in WHC-SD-WM-ISB-O01.

Eloctrical service upgrades to the SY Tark Farm are the same as for the AN Tank Fam with exceptions as follows: The spare circuit breaker for the existing load center substation will not be provided. Power will be supplied to two 3 HP annulus exhaust fans which will replace the two existing 2 HP fans, two snnulus supply heaters for esch of the three SY tanks, a new mini-power center for $120 \mathrm{v}$ to instrumentation and control panel. The wisting feeder 30 a circuit breaker will be replaced with a 80 a breaker and the $\$ 8$ AWG feeder wires will be replaced with \#4 AWG. Changes involve only enhancements to existing systems and involve no procedural changes in WHC-SD-WM-SAR-016. There will nocessarily be facility descriptive changes in WHC-SD-WM-ISB-001.

AN2-21

B. Does the PROPOSED CHANGE represent a change to procedures as described in the AUTHORIZATION BASIS? $\square N / A[X]$ No $\square$ Yes/Maybe

Basis: Procedural changes to the suthorization basis are not involved with this upgrade.

C. Does the test or experiment represent a test or experiment not described in the AUTHORIZATION BASIS documentation? [X] N/A DNo D Yes/Maybe

Basis: There are no tests or experiments that involve the authorization basis documentation.

D. Does the change, test or experiment impact:

- Implemented OSRs or IOSRs? [N/A [X]No D Yes/Maybe

- Approved IOSR Compliance Implementation Plans? ON/A [X] No D Yes/Maybe

Basis:

Based on the above, a Safety Evaluation 0 DOES [X] DOES NOT need to be performed for this change 
USQ Tracking No:

\section{REFERENCE DOCUMENT(S):}

ECN No.

Work Pkg No.
Rev. No.:

PCANo.

Other (Specify) WHC-SD-w314-CDR-001, Rev. 0

TITLE: Electrical upgrades to 244-A DCRT

A. Does the PROPOSED CHANGE represent a change to the facility as described in the AUTHORIZATION BASIS documentation?

DN/A [X] No QYes/Maybe

Basis: A new panelbard will be installed to replace the existing power distribution center located inside the 244-A instrument enclosure. The new panelboard will be fod from the existing MCCl located at the 244-A building and will provide power to the new ventilation system, the existing load of the power distribution center, and the existing 244-A agitator, sump and transfer pumps. A new mini-power center will be provided to supply 120v AC power to the instrumentation and control panel. This mini-power center will be fed from the new panelbourd. The existing fooder of the power distribution center will be disconnected and removed from the existing 50 circuit breaker (compartment DS) of the MCC-2 located in the 244-AR building. The existing loads of the power distribution center will be disconnected, removed and connected to the new panelboard. A new 125a, 3 pole, 600v, AC circuit breaker uill be installed in compartment B-5 of the existing MCCl located in the 242-A building. A new feeder for the new panelboard will be installed. The existing foeders of the 244.A agitator, sump and transfer pumps will be disconnected and removed from the existing $\mathrm{MCCl}$ located in the 244-A building. New fooders from the new panelbosid will be installed. Only facility descriptions in WHC-SD-WM-ISB-00I, Rev. 0 will be required.

B. Does the PROPOSED CHANGE represent a change to procedures as described in the AUTHORIZATION BASIS? DN/A [X] No o Yes/Maybe

Basis: No authorization basis documents will be affected by the upgrades.

C. Does the test or experiment represent a test or experiment not described in the AUIHORIZATION BASIS documentation? [X] N/A DNo D Yes/Maybe

Basis: No tests or experiments are involved with the upgrades.

D. Does the change, test or experiment impact:

- Implemented OSRs or IOSRs? QN/A [X] No QYes/Maybe

- Approved IOSR Compliance Implementation Plans? ON/A $[X]$ No O Yes/Maybe

Basis:

Based on the above, a Safety Evaluation need to be performed for this change IDOES [X]DOES NOT 
USQ Tracking No:

\section{REFERENCE DOCUMENT(S):}

ECN No.

Work Pkg No.

TITLE: AN, AP, AW Primary Ventilation System Upgrade
Rev. No.:

PCANo.

Other (Specify) w314-CDR-001

A. Does the PROPOSED CHANGE represent a change to the facility as described in the AUTHORIZATION BASIS documentation?

DN/A QNo [X] Yes/Maybe

Basis: These changes are to replace the existing ventilation systems with new dual high capacity filter trains, new fans, new stacks, stack -.- monitoring/control systems, and enhancod safety features. These changes will require updating the AN, AP, and AW facilities descriptions as deseribed WHC-SD-WM-SAR-016.

B. Does the PROPOSED CHANGE represent a change to procedures as described in the AUTHORIZATION BASIS? DN/A $\square$ No $[\mathrm{X}]$ Yes/Maybe

Basis: New systems coupled with enhanoed safty feahures uill change certain operability characteristics in procedures, however the overall function of the new systems will remain the same.

C. Does the test or experiment represent a test or experiment not described in the AUTHORIZATION BASIS documentation? [X] N/A QNo DYes/Maybe

Basis: The upgrades are not considered a test or experiment

D. Does the change, test or experiment impact:

- Implemented OSRs or IOSRs? QN/A [X]No D Yes/Maybe

- Approved IOSR Compliance Implementation Plans? [N/A [X] No Q Yes/Maybe

Basis: DST IOSRs aplicable to the AN, AP, and AW tank farms Primary Vent. Systems upgrade are LCOs 3.4.1, 3.4.2, and 3.4.3. The proposed upgrade will be compliant with these IOSRs.

Based on the above, a Safety Evaluation - [X] DOES DDOES NOT need to be performed for this change

- The proposed upgrades to the Primary Vent. Systems for the above mentioned farms represent additions that may inlluence certain operability characteristics. 


\section{UNREVIEWED SAFETY QUESTION SCREENING FORM}

(Per WHC-IP-0842)

USQ Tracking No.:

\section{REFERENCE DOCUMENT(S):}

ECN No.

Work Pkg No.
Rev. No.:

PCA No.

Other (Specify) WHC-SD-W314-CDR-001, Rev. 0

TITLE: Electrical upgrades to 244-S DCRT

A. Does the PROPOSED CHANGE represent a change to the facility as described in the AUTHORIZATION BASIS documentation?

DN/A [X]No Q Yes/Maybe

Basis: A new 75kVA, $13.8 \mathrm{kV}-480 \mathrm{Y} / 277$ VAC, 4-wire, 60Hz will be provided to replace the existing 3-25kVA, 1申, pole mounted transformers that are connected to the existing overhead $2.4 \mathrm{kV}$ line EB-L115. The new transformer will be connected to the existing overhead $13.8 \mathrm{kV}$ line C8LA and will feed the existing servioe distribution panelboard " $A$ " located inside the 244-S instrument enclosure. A new service metering and disconnect switch will be provided for the new service feeder to the existing panelboard. The existing $2.4 \mathrm{kV}$ lightning arresters, fused cutouts and existing feeder conductors to the existing panelboard will be removed. A 480V, 3\$, $60 \mathrm{~Hz}$ power system to the new DCRT ventilation system from the existing service distribution panel "A" will be provided. A new minj-power center vill be provided to supply $120 \mathrm{v}$ power for the instrumentation and control panel. The min-power center will be fed from the existing service distribution panelbourd "A". Only facility deseriptions in WHC-SD-WM-ISB-001, Rev. 0 will be required.

B. Does the PROPOSED CHANGE represent a change to procedures as described in the AUTHORIZATION BASIS?

\section{DN/A [X] No DYes/Maybe}

Basis: The authorization basis will not be affected by the upgrades.

C. Does the test or experiment represent a test or experiment not described in the AUTHORIZATION BASIS documentation? [X] N/A aNo aYes/Maybe

Basis: No tests or experiments are involved with the upgrades.

D. Does the change, test or experiment impact:

- Implemented OSRs or IOSRs? DN/A [X] No DYes/Maybe

- Approved IOSR Compliance Implementation Plans? ON/A [X] No O Yes/Maybe

Basis:

Based on the above, a Safety Evaluation DDOES [x] DOES NOT need to be performed for this change 
WHC-SD-W314-CDR-001, Rev. 0

\section{UNREVIEWED SAFETY QUESTION SCREENING FORM}

(Per WHC-IP-0842)

Page 1 of 1

USQ Tracking No.:

Rev. No.:

REFERENCE DOCUMENT(S):

ECN No.

PCA No.

Work Pkg No.

Other (Specify) WHC-SD-W314-CDR-001, Rev. 0

TITLE: Electrical upgrades to 200-Eust/200-West Areas. Cathodic protoction.

A. Does the PROPOSED CHANGE represent a change to the facility as described in the AUTHORIZATION BASIS documentation?

DN/A [X]No O Yes/Maybe

Basis: The existing retifers in Tank Ferms 241-A, -AX and -AY will be modified to accommodate and protect the new process piping linea aginst galvanic corrosion. New anodes, test stations, anode distribution and junction boxes, permanent reference eloctrodes and cables will be provided as required. Only fecility deseriptions in WHC-SD-WM-ISB-001, Rev. 0 will be required.

B. Does the PROPOSED CHANGE represent a change to procedures as described in the AUTHORIZATION BASIS?

DN/A [X]No Q Y Yes/Maybe

Basis: The upgrades will not involve changes to the euthorization basis.

C. Does the test or experiment represent a test or experiment not described in the AUTHORIZATION BASIS documentation? [x] N/A QNo Q Yes/Maybe

Basis: No tests or experiments are involved with the upgrades.

D. Does the change, test or experiment impact:

- Implemented OSRs or IOSRs? [N/A [X] No DYes/Maybe

- Approved IOSR Compliance Implementation Plans? [N/A [X]No Q Yes/Maybe

Basis:

Based on the above, a Safety Evaluation [ DOES [X] DOES NOT need to be performed for this change 


\title{
APPENDIX I
}

\author{
Permitting Plan
}

(Provided by Operating Contractor) 
WHC-SD-W314-CDR-001, Rev. 0

\section{PERMITTING PLAN}

FOR

PROJECT H-314

TANK FARM RESTORATION AND SAFE OPERATIONS PROJECT 


\section{EXECUTIVE SUMMARY}

This document describes the permitting plan for Project W-314, Tank Farm Restoration and Safe Operations Project. The recommended regulatory strategy is included that provides a preferred project approach.

A comprehensive review of environmental regulations has indicated that several environmental reviews (e.g. National Environmental Policy Act of 1969, State Environmental Policy Act of 1971), permits, and approvals are required before construction or operation of the Tank Farm infrastructure upgrades. The environmental reviews, permits, and approvals, as well the regulatory authority, potentially applicable to the upgrades associated with Tank Farm Restoration and Safe Operations Project are as follows:

National Environmental Policy Act of 1969 - U.S. Department of EnergyHeadquarters

- Environmental Assessment

- Categorical Exclusion

- Environmental Impact Statement

State Environmental Policy Act of 1971 - Washington State Department of Ecology

- Determination of Nonsignificance

- Mitigated Determination of Nonsignificance

- Determination of Significance

- State Environmental Policy Act of 1971 Environmental Checklist

\section{Air Permitting}

- National Emission Standards for Hazardous Air Pollutants (40 Code of Federal Regulations 61 Subpart H)

- Prevention of Significant Deterioration standards ( 40 Code of Federal Regulations 52.21) and (Washington Administrative Code Chapter 173-400)

- Ambient Air Quality Standards for Radionuclides (Washington Administrative Code Chapter 173-480)

- Radiation Protection - Air Emissions (Washington Administrative Code Chapters 246-247) 
- Controls for New Sources of Toxic Air Pollutants (Washington Administrative Code Chapter 173-460).

Dangerous Waste Permitting

- Dangerous Waste Permit (Washington Administrative Code Chapter 173-303)

Miscellaneous Reviews, Permits, and/or Approvals

- Preoperation Monitoring of Facilities, Sites and Operations U.S. Department of Energy, Richland Operations Office

- Cultural Resource Review Clearance - U.S. Department of Energy, Richland Operations office

- Excavation Permit - U.S. Department of Energy, Richland Operations Office

- Endangered Species Act of 1972 Approval - U.S. Department of Energy, Richland Operations Office.

A summary of data requirements, alternative strategies for completion of upgrade activities, and approval requirements are presented. 
CONTENTS

GLOSSARY . . . . . . . . . . . . . . . . . I-6

1.0 INTRODUCTION . . . . . . . . . . . . . . . . . . I-7

2.0 NATIONAL ENVIRONMENTAL POLICY ACT . . . . . . . . . . I-8

2.1 INTRODUCTION . . . . . . . . . . . . . I-8

2.2 SUMMARY OF DATA AND/OR INFORMATION REQUIREMENTS . . . . I-8

2.3 DISCUSSION OF ALTERNATIVES .............. I-9

2.4 RECOMMENDED PERMITTING STRATEGY . . . . . . . . . . I- I

2.5 PRELIMINARY COST ESTIMATE . . . . . . . . . . . . I-9

3.0 STATE ENVIRONMENTAL POLICY ACT . . . . . . . . . . . . I-9

3.1 INTRODUCTION . . . . . . . . . . . . . . I-10

3.2 SUMMARY OF DATA AND/OR INFORMATION REQUIREMENTS .... I-10

3.3 DISCUSSION OF ALTERNATIVES ............. I-1I

3.4 RECOMMENDED PERMITTING STRATEGY . . . . . . . . . . . I-11

3.5 PRELIMINARY COST ESTIMATE . . . . . . . . . . . . . I-11

4.0 RESOURCE CONSERVATION AND RECOVERY ACT . . . . . . . . . I-11

4.1 INTRODUCTION .................... I-11

4.1.1 Notice of Intent ............. I-12

4.1.2 Part A ............... I-12

4.1.3 Part B . . . . . . . . . . . . I-12

4.2 SUMMARY OF DATA/INFORMATION REQUIREMENTS . . . . . . I-13

4.3 DISCUSSION OF ALTERNATIVES ............. I-13

4.4 RECOMMENDED PERMITTING STRATEGY . . . . . . . . . . I-14

4.5 PRELIMINARY COST ESTIMATE . . . . . . . . . . . . . . . I-14

5.0 THE CLEAN AIR ACT . . . . . . . . . . . . . . . . I-14

5.1 INTRODUCTION ................ I-15

5.1.1 Radioactive Emissions .............. I-15

5.1.2 Nonradioactive Emissions . . . . . . . . . 1-16

5.2 SUMMARY OF DATA/INFORMATION REQUIREMENTS ....... . I-16

5.3 DISCUSSION OF ALTERNATIVES ............. I-17

5.4 RECOMMENDED PERMITTING STRATEGY . . . . . . . . . . . I-17

5.5 PRELIMINARY COST ESTIMATE . . . . . . . . . . . . I-18

6.0 MISCELLANEOUS ASSESSMENTS, PERMITS, AND APPROVALS . . . . I-18

6.1 CULTURAL RESOURCE REVIEW ............. I-18

6.2 EXCAVATION PERMIT . . . . . . . . . . . . . . . I-18

6.3 ENDANGERED SPECIES ACT COMPLIANCE

6.4 PREOPERATIONAL MONITORING OF FACILITIES, SITES, AND OPERATIONS ................. I-19

6.5 PRELIMINARY COST ESTIMATE ............. . . . . . . 19

7.0 REFERENCES ....................... . . . . . . . . . . . . 
WHC-SD-W314-CDR-001, Rev. 0

APPENDICES

A PROJECT W-314 TANK FARM RESTORATION AND SAFE OPERATIONS

PERMITTING SCHEDULE ................... I-20

B SUMMARY OF DATA/INFORMATION REQUIREMENTS FOR PROJECT W-314

TANK FARM RESTORATION AND SAFE OPERATIONS .......... I-3O 


\section{GLOSSARY}

ADM action description memorandum

BARCT best available radionuclide control technology

BCCAA Benton County Clean Air Authority

CAA Clean Air Act of 1977

CDR conceptual design report

CFR Code of Federal Regulations

CX categorical exclusion

DOE-HQ U.S. Department of Energy-Headquarters

DOE-RL U.S. Department of Energy, Richland Operations Office

DOH State of Washington Department of Health

DS determination of significance

DNS determination of nonsignificance

DST double-shell tank

EA environmental assessment

Ecology Washington State Department of Ecology

EIS environmental impact statement

EPA U.S. EnvironmentaT Protection Agency

FONSI Finding of No Significant Impact

IB Information Bulletin

IPM Initial Pretreatment Module

NAAQS National Ambient Air Quality Standards

NESHAPs National Emissions Standards for Hazardous Air Pollutants

NEPA National Environmental Policy Act of 1969

NOC notice of construction

NOD notice of deficiency

NOI notice of intent

PNNL Pacific Northwest National Laboratories

PSD prevention of significant deterioration

PSE preliminary safety evaluation

RCRA Resource Conservation and Recovery Act of 1976

SEPA State Environmental Policy Act of 1971

SEIS state environmental impact statement

SQE small quantity emission

TAPs toxic air pollutants

T-BACT best available control technology for toxics

TSD treatment, storage, and/or disposal

VOCs volatile organic compounds

WAC Washington Administrative Code 
WHC-SD-W314-CDR-001, Rev. 0

\section{PERMITTING PLAN FOR PROJECT $W-314$ \\ TANK FARM RESTORATION AND SAFE OPERATIONS PROJECT}

\subsection{INTRODUCTION}

This document describes permitting requirements for design, construction, and operation for Project W-314, Tank Farm Restoration and Safe Operations infrastructure upgrades to ensure that the project activities can support the mission of safe, near-term storage and management of waste.

These infrastructure upgrades are divided into four major areas (1) waste transfer systems (e.g., piping/ancillary equipment), (2) ventilation, (3) instrumentation and/or controls, and (4) electrical. These upgrades will support Tank Farm operations compliance with applicable federal, state, and local regulations. In addition, equipment downt ime and operational costs will be reduced, and risks associated with radioactive and/or hazardous materials releases will be decreased. There will be no liquid effluents released to the environment as part of these upgrades.

The waste transfer system upgrades include affixing new protective coatings within selected valve and pump pits, providing new transfer lines in selected locations, and replacing transfer piping in selected locations. Cathodic protection will be provided for piping as required.

The ventilation systems upgrades include replacement of existing primary tank ventilation systems for the AN, AP and AW Double-Shell Tank (DST) Farms, upgrading the annulus ventilation system for SY Tank Farm, and upgrading the 244-A and 244-S double-contained receiver tank (DCRT) ventilation systems. Included with the ventilation system upgrades are seal pot and/or drainage systems and filtration systems.

The instrumentation and/or controls upgrades include replacement of aging and/or deteriorated DST monitoring instrumentation, upgrades to the 244-A and 244-S DCRTs' monitoring instrumentation, upgrades to DST and waste transfer leak detection/master pump shutdown systems, and enhancements to the information management system.

The electrical upgrades include the DST electrical equipment and wiring, as well as 244-A and 244-S DCRT electrical equipment and wiring.

Milestones M-43-09 through M-43-16 established in the Hanford Federal Facility Agreement and Consent Order (Tri-Party Agreement) require that Project $W-314$ will design and construct Tank Farm upgrades. Milestone M-43-09 requires completion of a conceptual design report by May 31,1996 . Milestone $M-43-10$ requires the start of definitive design by January 31 , 1997. The project construction schedule (due September 30, 1998) and individual Tank Farms' construction milestones are listed as $\mathrm{M}-43-11$ through M-43-16 (due between June 30, 1999 and June 30, 2003).

This permitting plan has been prepared based on the scope of work defined in the Project W-314 Conceptual Design Report (WHC 1996). 


\subsection{NATIONAL ENVIRONMENTAL POLICY ACT}

The NEPA (42 U.S.C. 4321 et seq.) was enacted to ensure that environmental matters are considered before initiation of federal actions that might affect the quality of the human environment. The U.S. Department of Energy (DOE) regulations [10 Code of Federal Regulations (CFR) 1021] promulgated under NEPA were developed to conform with 40 CFR 1500-1508 regulations and to categorize the environmental impacts associated with various DOE proposals or actions.

\subsection{INTRODUCTION}

If a proposed action appears to be covered under an existing approved environmental impact statement (EIS) or environmental assessment (EA), the relevant record of decision (ROD) or finding of no significant impact (FONSI) should be examined to ensure the proposed action is adequately bounded by existing documentation.

In the event that U.S. Department of Energy, Richland Operations office (DOE-RL) determines that a proposed action is not covered by existing environmental documentation, an evaluation would be required to determine whether the proposed action falls within one of the categorical exclusions (CX) per 10 CFR 1021. If the proposed action is covered by a CX, a memorandum is prepared that summarizes the proposed action and its background. In addition, an explanation of how the action meets the minimum requirements of a $C X$ is needed.

If the proposed action is not covered by a $C X$, a decision whether or not the project warrants an EA or EIS must be made by DOE-RL.

Following a decision by the DOE-RL, an EA is developed to discuss the environmental consequences of the proposed action and the alternatives to that action, including the consequences of accidents and routine operations and the cumulative and long-term impacts. The relationship of the proposed action to federal, state, and local land use plans, policies, and regulations also is discussed in the EA. The EAs are submitted to the DOE-RL for final determination. This determination will result in a decision that the proposed action is a major action significantly affecting the environment, requiring an EIS, or issuance of a FONSI.

\subsection{SUMMARY OF DATA AND/OR INFORMATION REQUIREMENTS}

A summary of the minimum data and/or information needs required for development of the NEPA documentation for the Project W-314 Tank Farm Restoration and Safe Operations is provided in Appendix B. 


\subsection{DISCUSSION OF ALTERNATIVES}

Various NEPA compliance alternatives might be available in an effort to support Tank Farm Restoration and Safe Operations upgrades. The alternatives open for consideration are as follows. The aiternative are listed in order of probability of success.

1. A determination that an EA is required will be made. The desired outcome of the EA would be a FONSI, after which the Title II design effort for Project W-314 could proceed.

2. Alternative 2 is the possibility of NEPA coverage of the Tank Farm Restoration and Safe Operations upgrades under the Tank Waste Remediation System (TWRS) EIS, if the TWRS EIS ROD is delayed until the Spring of 1997. However, if the ROD is delayed until the Winter of 1997, an EA would be prepared.

3. Same as alternative 1 but the outcome of the EA is a requirement to prepare an EIS.

4. This alternative would involve preparation of an EIS without first developing an EA.

\subsection{RECONMENDED PERMITTING STRATEGY}

For design and construction activities associated with most of the Tank Farm Restoration and Safe Operations upgrades, an EA will be prepared. The waste transfer upgrades associated with Project $W-314$ will be covered in the TWRS-EIS. The assumed outcome of this EA is a FONSI, which is needed before initiating Title II design. (Refer to Appendix A for the Project W314 permitting schedule.)

\subsection{PRELIMINARY COST ESTIMATE}

Cost estimates for planning purposes have been developed showing a total cost for EA preparation and approval of $\$ 178 \mathrm{~K}$.

\subsection{STATE ENVIRONMENTAL POLICY ACT}

The SEPA (Chapter 43.21C Revised Code of Washington) legislation is the Washington State equivalent of NEPA, which requires evaluation of environmental impacts associated with a project or an agency action before approval. The SEPA Rules, Washington Administrative Code (WAC)

Chapter 197-11, are the implementing regulations. 


\subsection{INTRODUCTION}

One regulatory agency will be identified as lead agency for each project. The lead agency is responsible for ensuring that SEPA compliance is completed before approving the proposed project. The SEPA compliance is required for any project or proposal that meets the definitions of "action" in the SEPA Rules (WAC 197-11-704), and includes projects that require a permit (e.g., dangerous waste permit, building permit) or other approval from a governmental agency before operation. On the Hanford Site, Washington State Department of Ecology (Ecology) is the lead agency for projects ("Actions") involving permitting of dangerous waste treatment, storage, and/or disposal (TSO) units.

The SEPA compliance is required, in addition to other permits or approvals, for a project and is completed before the lead agency makes a decision to approve the project. On the Hanford Site, a SEPA environmental checklist is prepared and submitted to Ecology. The permit and/or approval may be conditioned or denied based on information contained in the SEPA environmental checklist.

When SEPA compliance is required for a project, the responsible official of the lead agency must make a threshold determination by deciding if a project is likely to have probable significant adverse impacts on the environment. If a project might have significant adverse impacts, a determination of significance (DS) will be issued and a state environmental impact statement (SEIS) would be required. If the project will not have significant adverse impacts, or if the impacts could be mitigated, a determination of nonsignificance (DNS) or mitigated DNS will be issued. The threshold determination normally is based on the environmental checklist completed for the project and any information the lead agency has on file.

The lead agency may adopt a NEPA EA or EIS in 1 ieu of doing a SEPA checklist or additional review under SEPA (WAC 197-11-610) to satisfy SEPA compliance and a determination of nonsignificance (DNS) or mitigated DNS will be issued.

\subsection{SUMMARY OF DATA AND/OR INFORMATION REQUIREMENTS}

A summary of the minimum data and/or information needs required for development of the SEPA documentation for the Project W-314 Tank Farm Restoration and Safe Operations is provided in Appendix B. 


\subsection{DISCUSSION OF ALTERNATIVES}

Various SEPA avenues might be evaluated in an effort to support the Project W-314 Tank Farm Restoration and Safe Operations upgrades. The alternatives open for consideration are as follows. The alternatives are listed in order of the probability of success.

1. A DNS following adoption of NEPA documentation (EA) by Washington State for the Tank Farm Restoration and Safe Operations upgrades.

2. A mitigated DNS from Washington State.

3. A DS from Washington State and a requirement to prepare separate SEISs.

\subsection{RECOMMENDED PERMITTING STRATEGY}

It is expected that Ecology will adopt the NEPA EA in 7 ieu of doing additional reviews to satisfy SEPA compliance, and a determination of nonsignificance (DNS) or mitigated DNS would be issued.

This will meet the requirements of SEPA and the appropriate level of documentation needed. (Refer to Appendix A for the Project W-314 NEPA permitting schedule.)

\subsection{PRELIMINARY COST ESTIMATE}

No additional cost is expected to be incurred for SEPA documentation. The cost is to be incorporated within the NEPA documentation.

\subsection{RESOURCE CONSERVATION AND RECOVERY ACT}

The RCRA (42 U.S.C. 6901 et seq.) was enacted as a comprehensive national program to mandate that hazardous waste be treated, stored, and disposed to minimize the present and future threat to human health and the environment. Washington State implements RCRA through WAC 173-303, Dangerous Waste Regulations.

\subsection{INTRODUCTION}

The WAC 173-303 regulations apply to all facilities within Washington State that treat, store, and/or dispose of dangerous waste. These regulations are equivalent to, or more stringent than, the federal hazardous waste regulations. Under the dangerous waste program, a7f TSD 
facilities must obtain a permit. Facilities that were in existence on November 19, 1980, were granted an interim status permit with the submittal of a Part A, Form 3, permit application identifying the intent to TSD of dangerous waste. Interim status ends after final administrative disposition of Part B permit application documentation is completed, and a final status permit is granted or denied.

An application for a TSD facility permit consists of three collective submittals. Each submittal consists of various levels of detailed information concerning the facility. The three submittals are the NOI, the Part A permit application (Part A, Form 3), and the Part B permit application documentation (Part B).

\subsubsection{Notice of Intent}

A NOI is required for proposed facilities and expansion at an existing facility. Expansion includes enlargement of 7 and surface area, the addition of new dangerous waste process, or an increase in overall design capacity. The NOI contains preliminary information concerning the proposed facility and/or expansion (WAC 173-303-281). The NOI requires a general process description, operating capacities, waste type, a topographic map, a statement of environmental conditions, and could include a SEPA environmental checklist.

In accordance with WAC 173-303-281, the NOI must be submitted to the public (public reading rooms), Ecology, and the U.S. Environmental

Protection Agency, Region 10. A pubiic notification is published in a local daily newspaper for 14 consecutive days. The NOI process normally requires approximately. Il months to complete. A Part A, Form 3 , is submitted no earlier than 150 days following submittal of the NOI to Ecology and the public.

\subsubsection{Part A}

The Part A, Form 3, includes process design capacity, process description, dangerous waste numbers (WAC 173-303) and estimated annual quantity, description of dangerous waste, facility diagrams, photographs, geographic location, and facility owner, operator/co-operator certification.

\subsubsection{Part B}

The Part B permit application documentation provides a detailed definition of the processes to be used for treatment, storage, and/or disposal of dangerous waste; the design capacity of such processes; and the specific dangerous waste types to be managed. This detailed information is used by the regulatory agency(s) to prepare a final status permit for the operation of the TSD facility. 
WHC-SD-W314-CDR-001, Rev. 0

\subsection{SUMMARY OF DATA/INFORMATION REQUIREMENTS}

A summary of the minimum data and/or information needs required for development of Part $B$ permit application documentation is provided in Appendix B.

\subsection{DISCUSSION OF ALTERNATIVES}

Various avenues may be evaluated in an effort to support the Tank Farm Restoration and Safe Operations upgrades. The alternatives open for consideration are as follows. The alternatives are listed in order of the probability of success.

1. A revision (working draft) to the DST System Part B permit application documentation that will be prepared in 1997 will be required.

The assumption is that upgrades are not reflected in the DST System Part B, and these upgrades could affect critical systems. (Critica) systems are those specific portions of a TSD unit's structure or equipment whose failure could lead to the release of dangerous waste into the environment and/or systems that include processes that treat, transfer, store, or dispose of regulated waste. Ancillary equipment includes devices such as piping, fittings, flanges, valves, and pumps used to distribute, meter, or control the flow of dangerous waste from its point of generation to a point of disposal).

2. A modification to the Hanford Facility RCRA Permit will be required.

The assumptions include the following:

(a) The project design media will not be complete and as-built drawings will not be submitted with the DST System Part B permit application (working draft) to be submitted 1998).

(b) The descriptive Part B text does not reflect the upgrades because information is not available in sufficient detail.

3. A revision to the DST and SST closure documentation will be required.

The assumption is that information concerning upgrades is not available in sufficient detail to be incorporated into closure documents, which are currently being processed.

4. Prepare and submit a NOI and/or revise the Part A, Form 3, applications for the DST and SST Systems. 
WHC-SD-W314-CDR-001, Rev. 0

The assumptions inciude the following:

(a) Upgrades do not affect expansion (Section 4.1.1).

(b) The upgrades do not increase process capacities.

(c) Dangerous waste numbers are not changed from those identified in the Part $A$.

\subsection{RECOMMENDED PERMITTING STRATEGY}

A revision to the DST System Part B permit application will be required and Project W-314 upgrades can be included in that document. The preferred permitting strategy is to reflect the upgrades as future systems in the application before the current working draft document is submitted to Ecology.

Because sufficient design information for Project W-314 may not be available before submittal of the DST System Part B to Ecology, a future permit modification may be required. The objective will be to reflect as much avajlable information in the document to be prepared in 1997 to avoid a modification of the 1999 final status permit. It is anticipated that this approach will require submittal of as-built design media as a condition of final status.

It is assumed that waste transfer systems will be replaced or added but no changes to TSD capacity or process capabilities will occur. RRefer to Appendix $A$ for the Project W-314 permitting schedule.)

\subsection{PRELIMINARY COST ESTIMATE}

Detailed design information will not be available before March 31 , 1997, for submittal to Ecology. Upgrade information that is available will be included in the revision (working draft) to the DST System Part B.

There will be additional costs incurred for future submittals associated with as-built drawings, Titie II, and design media at a cost of \$3K for each submittal.

\subsection{THE CLEAN AIR ACT}

The Federal Clean Air Act (42 U.S.C. 7401 et seq.) was enacted in 1970, amended in 1977, and overhauled and expanded in 1990. 


\subsection{INTRODUCTION}

The Tank Farm Restoration and Safe Operations upgrades will require several permits and approvals before construction. These permits and approvals will be issued by several regulatory agencies, including the EPA, Ecology, Washington State Department of Health (WDOH), and the Benton County Clean Air Authority.

Permitting and emission standards administered by these agencies are contained in the following regulations:

- NESHAPs (40 CFR 61 Subpart H)

- Prevention of Significant Deterioration (PSD) standards (40 CFR 52.21 and WAC 173-400)

- Ambient Air Quality Standards for Radionuclides (WAC 173-480)

- Radiation Protection - Air Emissions (WAC 246-247)

- Controls for New Sources of Toxic Air Pollutants (TAPs) (WAC 173-460).

\subsubsection{Radioactive Emissions}

Radioactive air emissions currently are regulated by both the EPA, pursuant to 40 CFR 61 Subpart H, and the WDOH, pursuant to WAC 246-247. Both regulations require preconstruction approval from the respective agencies. Additionally, the WDOH requires extensive information on the technologies chosen to control radioactive air emissions, inciuding an assessment of all known control technologies. This assessment, referred to as a best available radionuclide control technology (BARCT) assessment, evaluates the universe of available control technologies. For Tank Farm Restoration and Safe Operations upgrades, the 'Best' technology must be installed, as determined by the BARCT assessment. The EPA also requires the sampling and monitoring system to meet specific criteria. These criteria, including requirements on the placement and number of sample probes, are applicable if the estimated dose equivalent from the facility to the maximally exposed offsite individual is greater than 0.1 mrem per year and when, hypothetically, no emissions control equipment is in place but operations are otherwise routine.

The WAC 246-247 regulations require varying degrees of information depending on the quantity of emissions. It is expected that the these upgrades will require the highest level of information for the WAC 246-247 application, and will require preconstruction approval under the NESHAPs regulations. 
Before the BARCT assessment, extensive information on the processes and expected emissions from these processes must be developed. This information is required to perform an adequate BARCT assessment. Information normaliy not available until definitive design (particularly concerning sampling equipment and expected emissions) is crucial to the preparation of the permit applications.

\subsubsection{Nonradioactive Emissions}

Nonradioactive air emissions of concern are expected to fall into one of two categories: criteria pollutants and TAPs.

Criteria pollutants are those subject to the PSD program, enforced by Ecology. Ecology has incorporated by reference most of the federal PSD requirements. The Tank Farm Restoration and Safe Operations upgrades are not expected to allow emissions exceeding the trigger levels for criteria pollutants (this assumption is based on previous Tank Farm estimates).

The TAPs are a separate class of emissions, regulated by Ecology pursuant to WAC 173-460. Over 500 carcinogenic and toxic pollutants are included in these regulations. Emissions will occur during installation and operation of the ventilation systems associated with the Tank Farm Restoration and Safe Operations upgrades; WAC 173-460 is applicable, and there is no de minimis level below which preconstruction approval is not required. While WAC 246-247 regulations require installation of BARCT, the TAPs regulations require the installation of best available control technology for toxics (T-BACT). Additionally, if emissions of pollutants (after controls) exceed the small quantity emission (SQE) rates included in the regulations, modeling must be performed to demonstrate that the offsite concentration of each pollutant of concern does not exceed the acceptabie source impact levels. Some pollutants do not have SQE rates, and modeling is required for any level of emission.

If any criteria poliutant approaches its trigger level, the information required by the PSD process would be included in a single application to Ecology. Ecology refers to these air permit applications as Notice of Constructions (NOCs).

\subsection{SUMMARY OF DATA/INFORMATION REQUIREMENTS}

A summary of the minimum data and/or information needs required for development of each of the air permit applications is provided in Appendix B. 


\subsection{DISCUSSION OF ALTERNATIVES}

Various avenues may be evaluated in an effort to support the air permitting for the Tank Farm Restoration and Safe Operations upgrades, and all of the following applications may be required. The length of the permitting process depends on the quantity of emissions and the availability of necessary information. The alternatives open for consideration are as follows. The alternatives are listed in order of the probability of success.

1. Obtain WAC $246-247,40$ CFR 61 Subpart $H$ (NESHAPs), and WAC 173460 (TAPs) approvals for al1 of Project $W-314$ when information necessary to complete the applications is available.

2. Obtain WAC $246-247,40$ CFR 61 Subpart H (NESHAPs), and WAC 173460 (TAPs) approvals separately as information to complete the applications becomes available.

3. Obtain WAC 246-247, 40 CFR 61 Subpart H (NESHAPs), and WAC 173460 (TAPs) approvals in a phased approach (and separate activities to be approved). The first phase would include obtaining approval for those Tank Farms with ventilation systems that require approval that have sufficient information available to complete the applications. The second phase would obtain approval for the remainder of the activities that require approval.

4. Obtain WAC 246-247, 40 CFR 61 Subpart H (NESHAPs), and WAC 173460 (TAPs) approvals in a phased approach (and separate activities to be approved). The first phase would include obtaining approval for all Tank Farm construction activities not directly associated with the ventilation systems. The second phase would obtain approval for activities associated with the ventilation systems.

\subsection{RECONMENDED PERMITTING STRATEGY}

The recommended strategy for the Tank Farm Restoration and Safe Operations upgrades is to secure the air permits (for applicable activities and affected facilities) before construction. It is expected that an application for approval to construct will be submitted for WAC 246-247, 40 CFR 61 Subpart H (NESHAPs), and WAC 173-460 (TAPS). It is assumed that the upgrades will not result in emissions exceeding significance levels for any criteria pollutants under the PSD program (which is based on previous analyses). Installation of BARCT will be required by WAC 246-247 and T-BACT will be required by the TAPs program. (Refer to Appendix A for the Project W-314 permitting schedule.) 


\subsection{PRELIMINARY COST ESTIMATE}

A preliminary cost estimate of $\$ 50 \mathrm{~K}$ has been developed for the activities associated with securing air permits and approvals. If BARCT and T-BACT assessments need to be prepared, each assessment will be an additional $\$ 25 K$.

\subsection{MISCELLANEOUS ASSESSMENTS, PERMITS, AND APPROVALS}

In addition to the major regulatory programs, several miscellaneous assessments, permits, and approvals are addressed in the following sections.

\subsection{CULTURAL RESOURCE REVIEW}

A cultural resource review will be performed before initiating any potential onsite surface disturbing activities (36 CFR 800 ). The regulatory agency is the DOE-RL. The culturai resource review will be submitted with the EA to the DOE-RL.

The regulatory strategy is based on activities performed within and 150 meters outside of the 18 fenced Tank Farm areas already covered by an existing cultural resource review [e.g., Cultural Resources Exemption of the Tank Farms Area (PNL 1994)]. A review of the existing CRR will be done before construction.

\subsection{EXCAVATION PERMIT}

An excavation permit will be required before initiating any potential onsite surface disturbing activities (36 CFR 800 ). The regulatory agency is the DOE-RL. The excavation permit, prepared before upgrade, construction activities will evaluate environmental impacts (e.g., soil and/or groundwater contamination).

\subsection{ENDANGERED SPECIES ACT COMPLIANCE}

A site assessment should be made to determine whether any planned activities have the potential to disturb any habitat used by wild ife before construction or habitat modification ( 50 CFR 402.6). The regulatory agency is the State or Federal Fish and Wildi ife Service. For onsite construction, a biological survey will be is performed. The survey report must accompany the EA when submitted to the DOE-RL.

The regulatory strategy is that the "1995 Blanket Biological Review of the 200 West and 200 East Tank Farms, 200 West and East Areas" (PNL 1995), dated March 28, 1995, will encompass the upgrade activities within the 200 East and 200 West Area Tank Farm boundaries. This survey report will be required before securing an excavation permit. 


\subsection{PREOPERATIONAL MONITORING OF FACILITIES, SITES, AND OPERATIONS}

An environmental study must be conducted before start up of a new site, facility, or process that has the potential for significant adverse environmental impact (DOE Order 5400.1). The regulatory agency is the DOE-RL. This study will be started at least I year before installation of the Tank Farm Restoration and Safe Operations upgrades.

As part of the preoperational monitoring requirements, a document needed for construction will be prepared that will specify the types of monitoring to be performed (e.g., radiation dose, ambient air, and surface radiological surveys).

\subsection{PRELIMINARY COST ESTIMATE}

It is assumed that there will be no additional cost associated with preparation of the cultural resource review or the Endangered Species Act compliance assessment (blanket assessments already approved).

There will be a cost for Preoperational Monitoring of Facilities, Sites, and Operations documentation of about $\$ 3 \mathrm{~K}$ and about $\$ 5 \mathrm{~K}$ for the excavation permits.

\subsection{REFERENCES}

Ecology, 1995, Dangerous Waste Permit Application Requirements, 95-402, Washington State Department of Ecology, Olympia, Washington.

EPA, 1996, "A Computerized Methodology for Estimating Environmental Concentrations and Dose to Man from Airborne Releases of Radionuclides", AIRDOS-EPA, EPA-5201-79-009, updated periodically, U.S. Environmental Protection Agency, Washington, D.C.

PNL, 1994, Cultural Resource Exemption of the Tank Farm Areas, Pacific Northwest Laboratory, Richland, Washington.

PNL, 1995, 1995 Blanket Biological Review of the 200 West and 200 East Tank Farms, 200 West and East Areas, PNL-95-200-073, Pacific Northwest Laboratory, Richland, Washington.

WHC, 1996, Project W-314 Conceptual Design Report, WHC-SD-W314-CDR-001, Rev. 0, Westinghouse Hanford Company, Richland, Washington. 
WHC-SD-W314-CDR-001, Rev. 0

APPENDIX A

PROJECT W-314 TANK FARM RESTORATION AND SAFE OPERATIONS PERMITTING SCHEDULE 


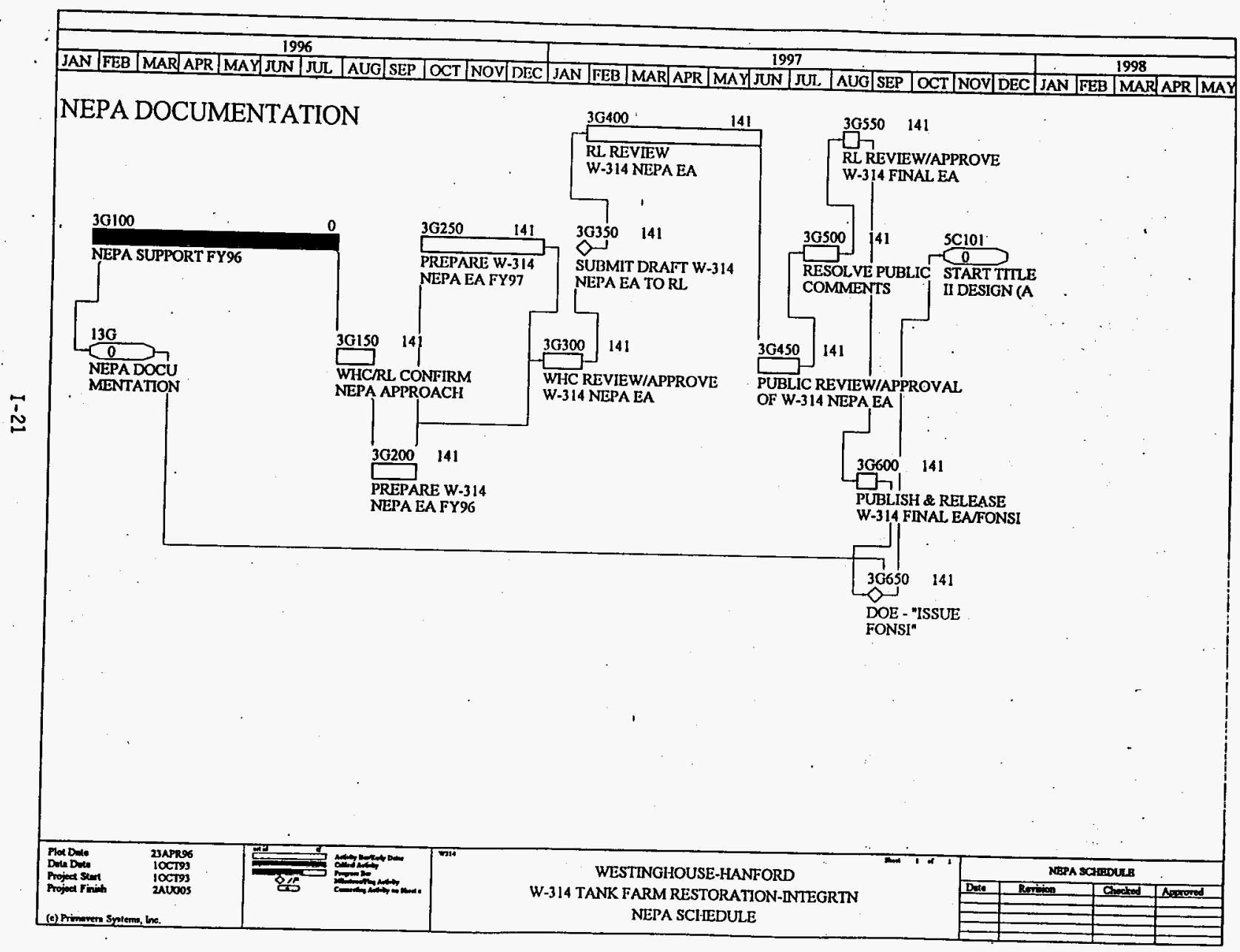




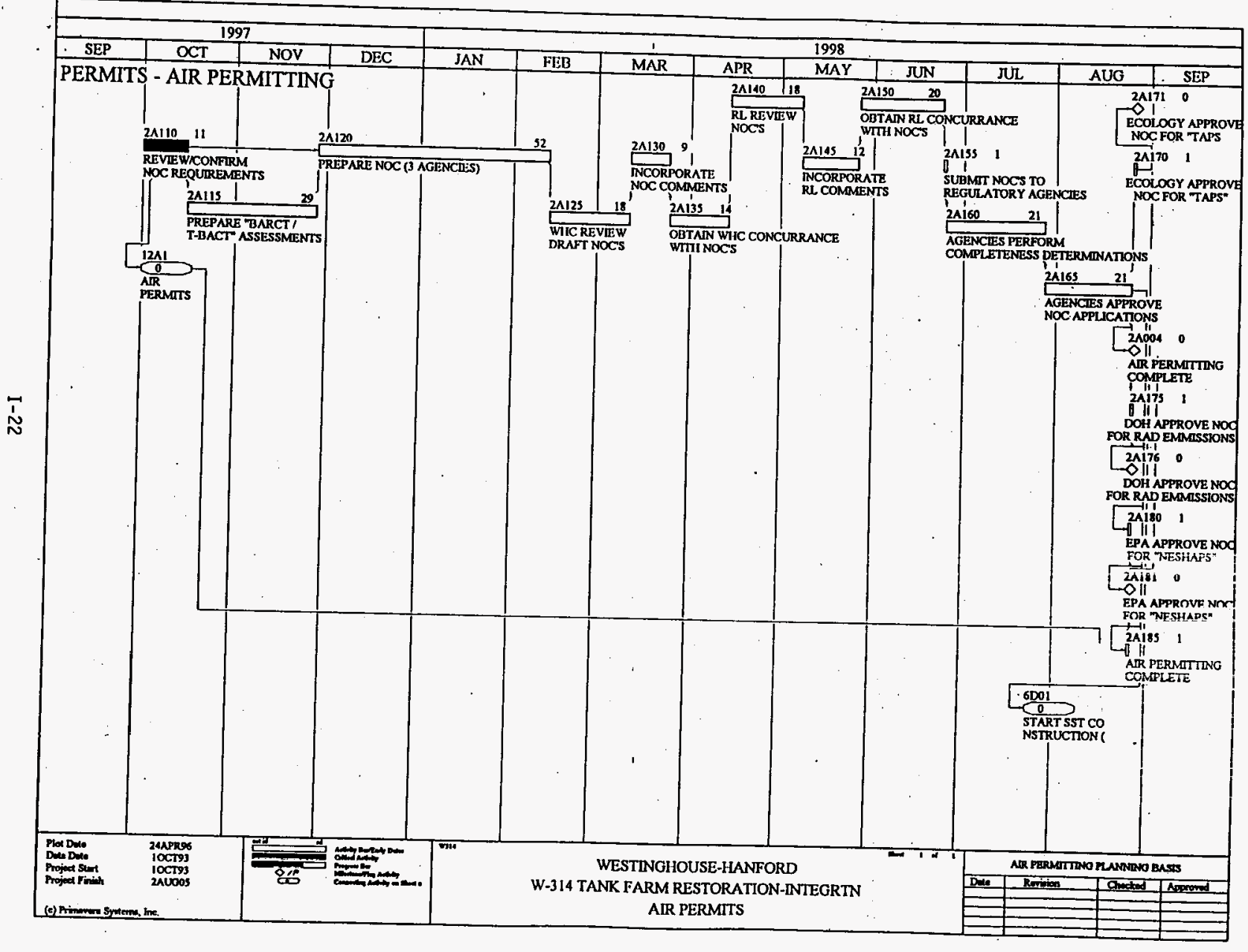




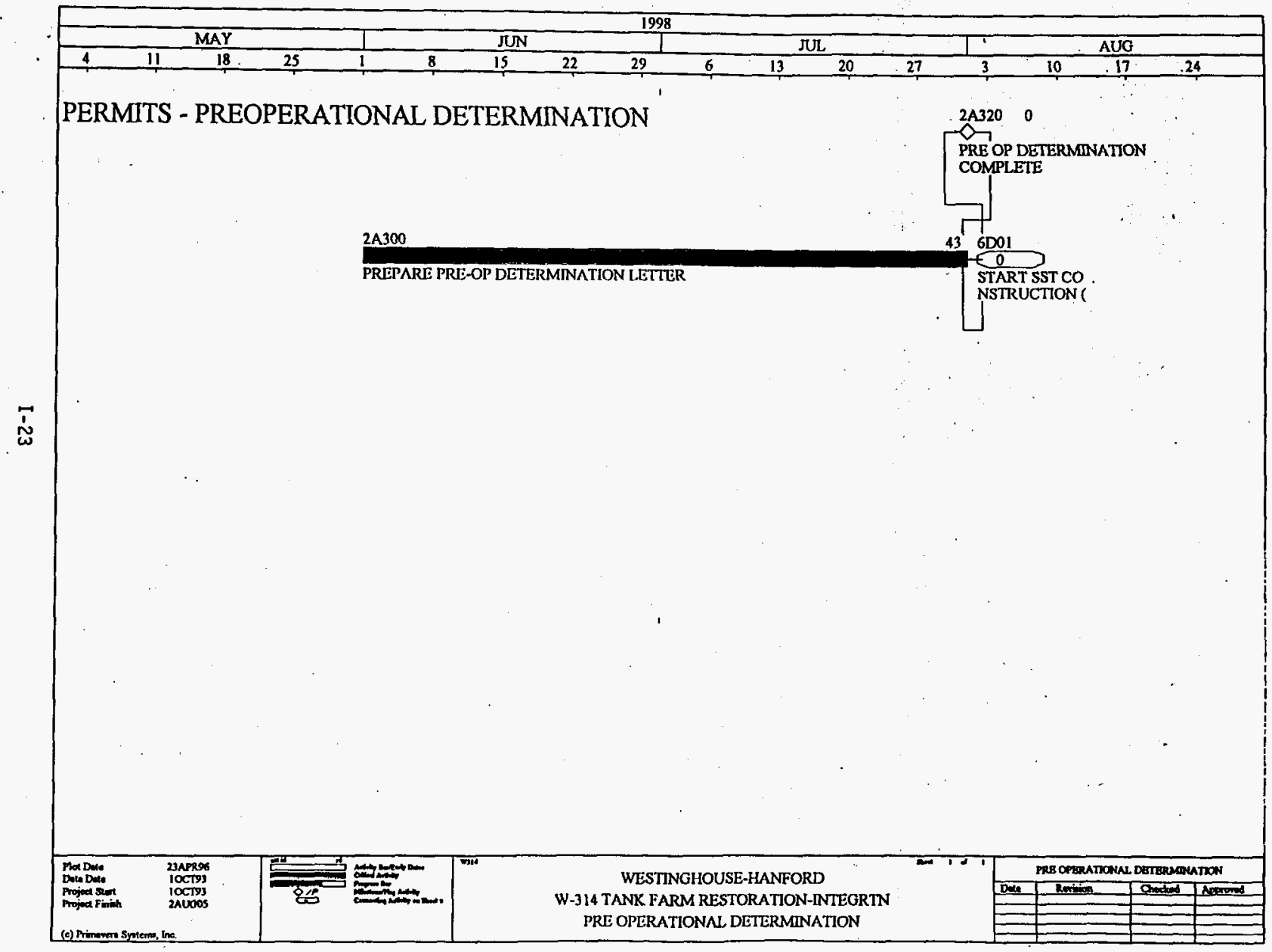




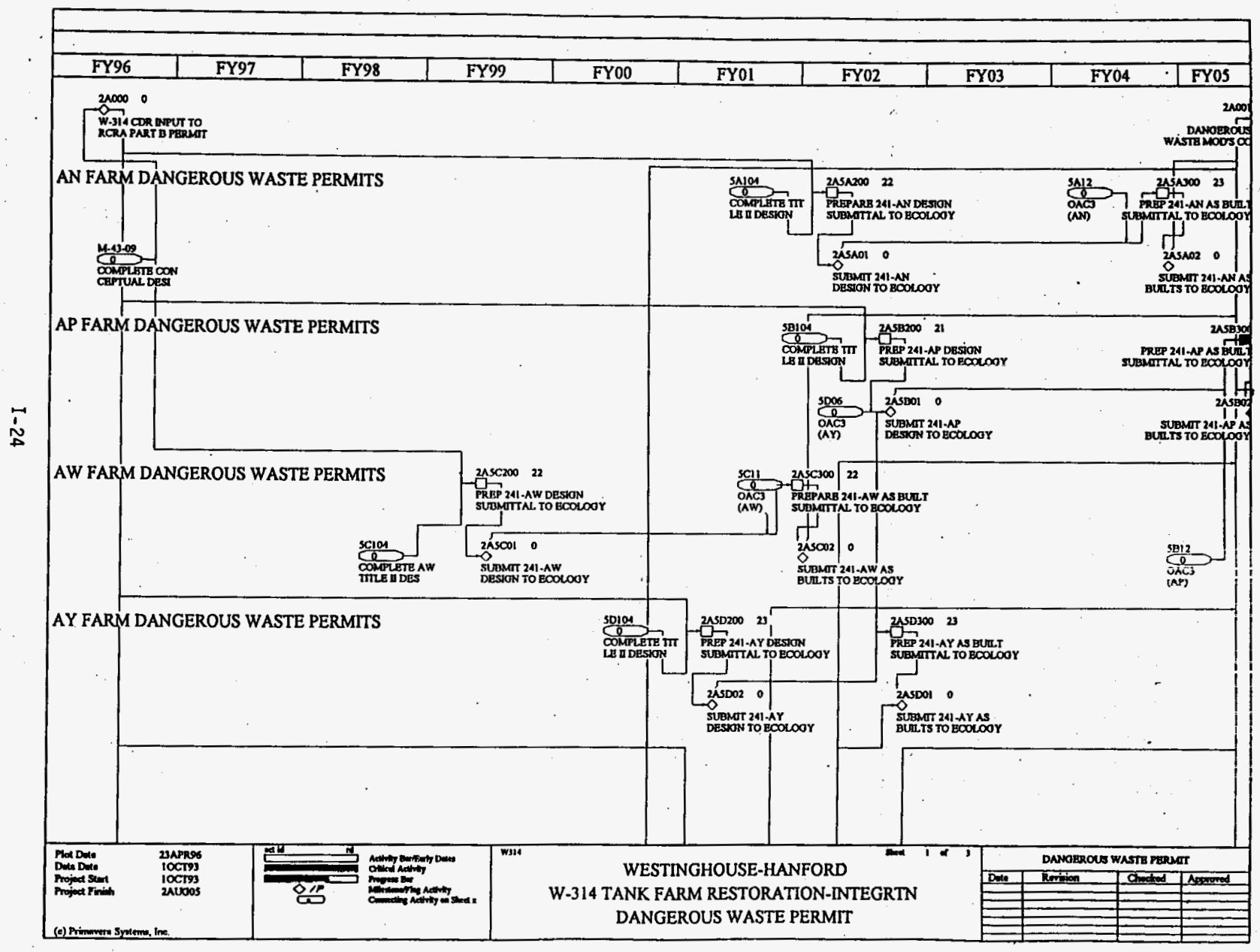




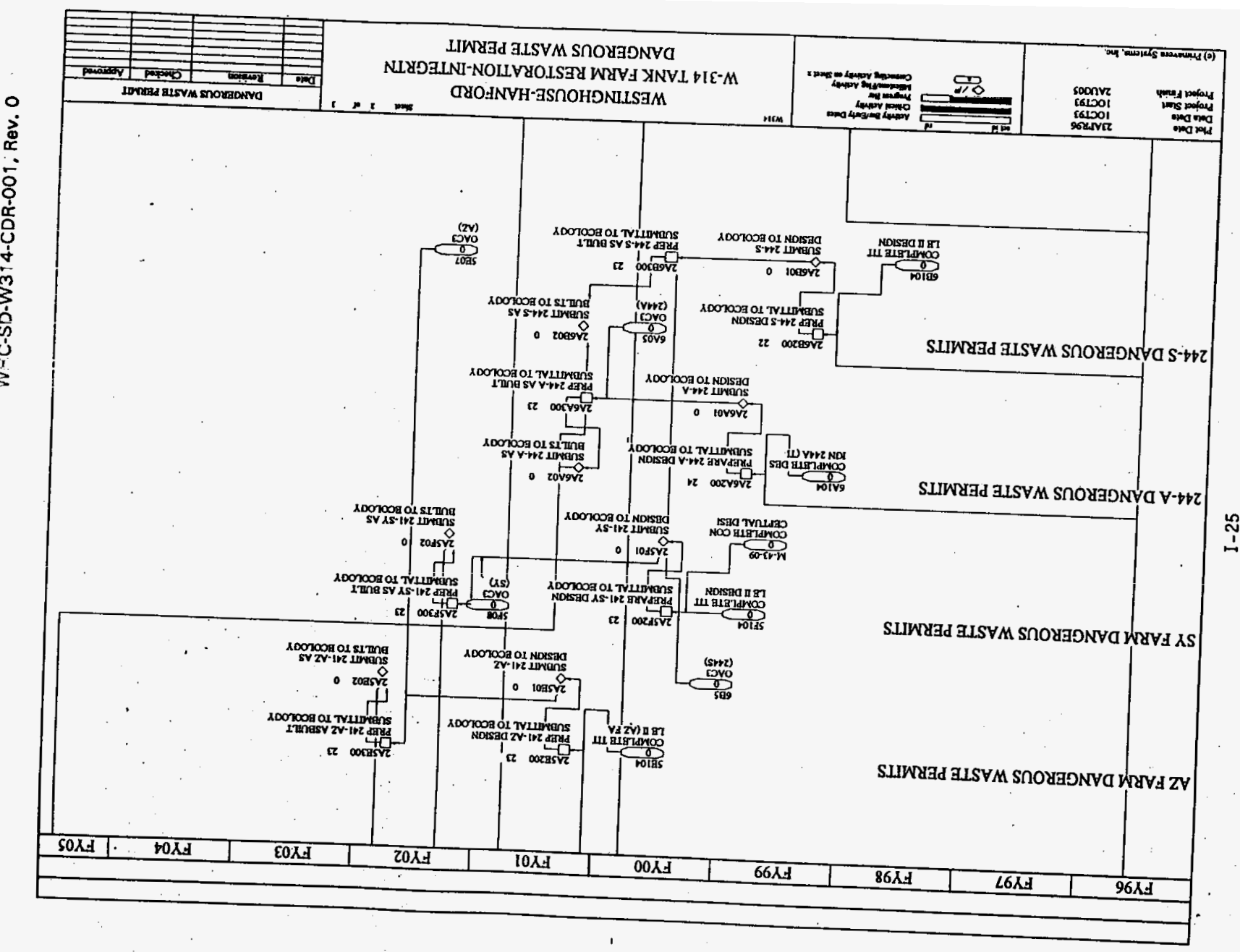




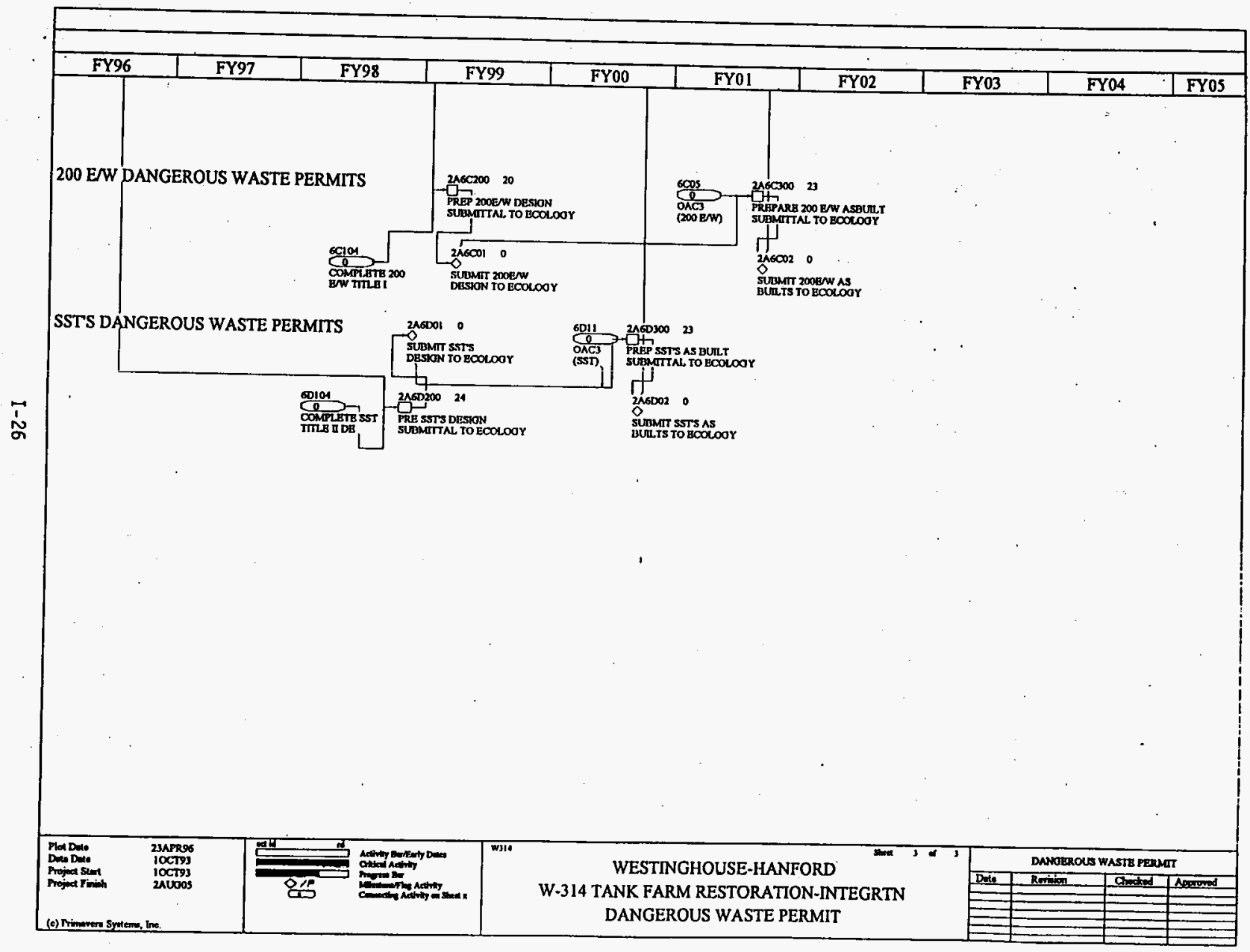


WHC-SD-W314-CDR-001, Rev. 0

APPENDIX B

SUMMARY OF DATA/INFORMATION REQUIREMENTS FOR

PROJECT W-314 TANK FARM RESTORATION AND SAFE OPERATIONS 


\section{SUMMARY OF DATA/INFORMATION REQUIREMENTS FOR PROJECT W-314 TANK FARM RESTORATION AND SAFE OPERATIONS}

\subsection{National Environmental Policy Act}

The minimum data and/or information requirements for NEPA documentation preparation are as follows:

- Conceptual or equivalent design information

- In addition, any other related engineering, safety, or waste evaluation documents would be helpful in NEPA preparation.

\subsection{State Environmental Policy Act}

The following are minimum data requirements for coordination of the SEPA requirements:

- Conceptual or equivalent design information is needed

- Any NEPA documentation (e.g., EA) that has been prepared or will be prepared for the Tank Farm Restoration and Safe Operations upgrades

- Any other related engineering, safety, or waste evaluation documents.

\subsection{Resource Conservation and Recovery Act}

The following is required for the revised Part B documentation: description of infrastructure upgrades and design media.

\subsection{Clean Air Act}

Detailed information on the treatment process, the emissions abatement system, the gaseous effluent monitoring system, and the nature of all gaseous emissions to the atmosphere is required for submissions made pursuant to the Clean Air Act. The appropriate regulations and administrative guidance should be consulted for the detailed requirements.

\subsection{Radioactive Emissions}

The following information is an abridged summary of the data and/or information needs for the NESHAP and WAC 246-247 permit applications and notice of construction. 
WHC-SD-W314-CDR-001, Rev. 0

\section{NESHAP Permit}

The 40 CFR 61.07 requires the application for approval to construct to include the following information:

- Technical description of the facility and its operations

- Size and location of the source

- Design and operating capacity of the source

- Method of operation (include process flow diagram)

- Nature of all gaseous emissions to the atmosphere:

- If a modification, the precise nature of the modification and estimates of emissions before and after completion.

- Technical description of emissions control system including release rates and offsite doses.

\section{WAC 246-247 Permit}

The WAC 246-247 regulations requires the application for approval to construct to include the following information:

- Facility information:

- Description of facility operations

- Facility identification must be the same as that appearing on source registration forms.

- Identification and listing of all sources consistent with the source registration identification

- Description of the source(s):

- System function and area exhausted

- Effluent systein layout

- Efficiency values of each control device for removal of radioactivity

- Means and frequency of testing and inspecting effluent treatment system

- Operating mode (continuous or batch)

- Chemical and physical nature of the emissions 
WHC-SD-W314-CDR-001, Rev. 0

- Stack or release point data

- Stack diameter and height

- Building height, width, and length

- Annual ambient average stack and ambient air temperatures

- Annual wind rose

- Chi/Q data

- Annual average volumetric flow rate

- Annual average release rates

- Fraction of facility's inventory available for potential release to the air.

- Description of the effluent sampling/monitoring systems:

- Stack flow measuring system

- Sample probes (isokinetic)

- Number and location of sampling points

- Sample lines

- Diameters, lengths, materials, bends, entry points into the effluent line, and angle of entry into the effluent

- Sample flow regulation

- Sampling media

- Frequency of sampling (continuous or batch)

- Frequency of sample collection

- Calibration and audit schedules.

- Environmental sampling monitoring system:

- Sampling network (location, number, distance from release points)

- Media sampled and/or monitored for the air pathway

- Equipment used for sampling and/or monitoring, including sampler flow rate and collection media 
- Frequency of sampling and/or monitoring

- Calibration and audit frequency.

- Hanford Site requirements for effluent sampling and/or monitoring system designs, procedures, and quality assurance standards (appropriate standards and description of how these are used)

- Effluent sample analyses including methodology, procedure references, detection limits, quality assurance (including internal audit schedule and results)

- Environmental sample analysis including methodology, procedure references, detection limits, quality assurance

- Data from effluent and environmental monitoring programs, including background or local control data

- Demonstration of compliance:

- Methodology used to demonstrate compliance

- Input data used

- Source terms, release height, inhalation rate, maximally exposed individual, meteorology

- Results of method (effective dose equivalent for whole body and relevant organs)

- Description of internal standards used to ensure compliance with applicable federal and state laws and regulations.

\subsection{Nonradioactive Air Emissions}

The following information is an abridged summary of the data and/or information needs for the NESHAP and WAC 246-247 permit applications and notice of construction.

\section{PSD Permit}

The WAC 173-400 regulations require an application for approval to construct to include such information as the following:

- Project location and emission source(s) 
- Design and operating parameters:

- Hours of operation

- Normal and maximum production rates

- Fuel requirements

- Raw material requirements

- Emissions control system.

- Emissions - Type and Quantity:

- Representative emissions from the existing source (for modification) over the most recent 2 year period of operation

- Projected actual controlled emissions at anticipated production rates and operating schedule for each pollutant at each emission point

- Projected potential controlled emissions; emission rate when equipment is operating at maximum capacity 24 hours per day, 365 days per year, taking air pollution control equipment into account.

- BACT/BARCT assessment:

- Literature search

- Control alternatives: comparison of efficiencies; energy, environmental, and economic impact analyses

- Summary.

- Analysis of current air quality at the proposed source location including presently existing ambient levels of the constituents being reviewed (from Pacific Northwest National Laboratory data)

- Analysis of the impact of the proposed source on ambient air quality:

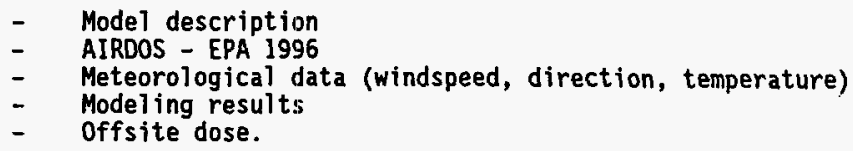


- Demonstration that the proposed emission will not cause a violation of national ambient air quality standards (NAAQS) or state standards using a direct comparison of modeling results with NAAQS

- Discussion of potential effects of the proposed upgrades on factors influenced by air quality such as residential or commercial growth, vehicular traffic, vegetation, soils, acid deposition, visibillity in sensitive areas, PSD increments, etc.

- Construction schedule.

Notice of Construction

The WAC $173-400$ and $173-460$ regulations require the application for approval to construct to include the following information:

- SEPA

- Notice of construction form

- Description of proposed source:

- Bid specifications, rated capacity, inputs, outputs, and byproducts generated

- Bid specifications, control efficiency, and operational requirements of the pollution control equipment

- Process flow diagram

- Estimate of stack emissions, including criteria and toxic air pollutants.

- Estimate of fugitive (nonstack) emissions

- $\quad$ BACT/T-BACT analysis

- Modeling. 


\section{APPENDIX $J$}

\section{Plant Forces Work Review}

(Direct construction activities, including tie-ins or completion of punchlist items, are not anticipated to be performed by the operating contractor. Therefore, in compliance with WHC-CM-6-2, PM-6, Rev. 2, a plant forces work review has not been prepared.) 